\title{
IMPACT OF POTENTIAL PHOSPHATE MINING ON THE HYDROLOGY OF OSCEOLA NATIONAL FOREST, FLORIDA
}

\section{U.S. GEOLOGICAL SURVEY}

Water Resources Investigations 78-6

Prepared in cooperation with the

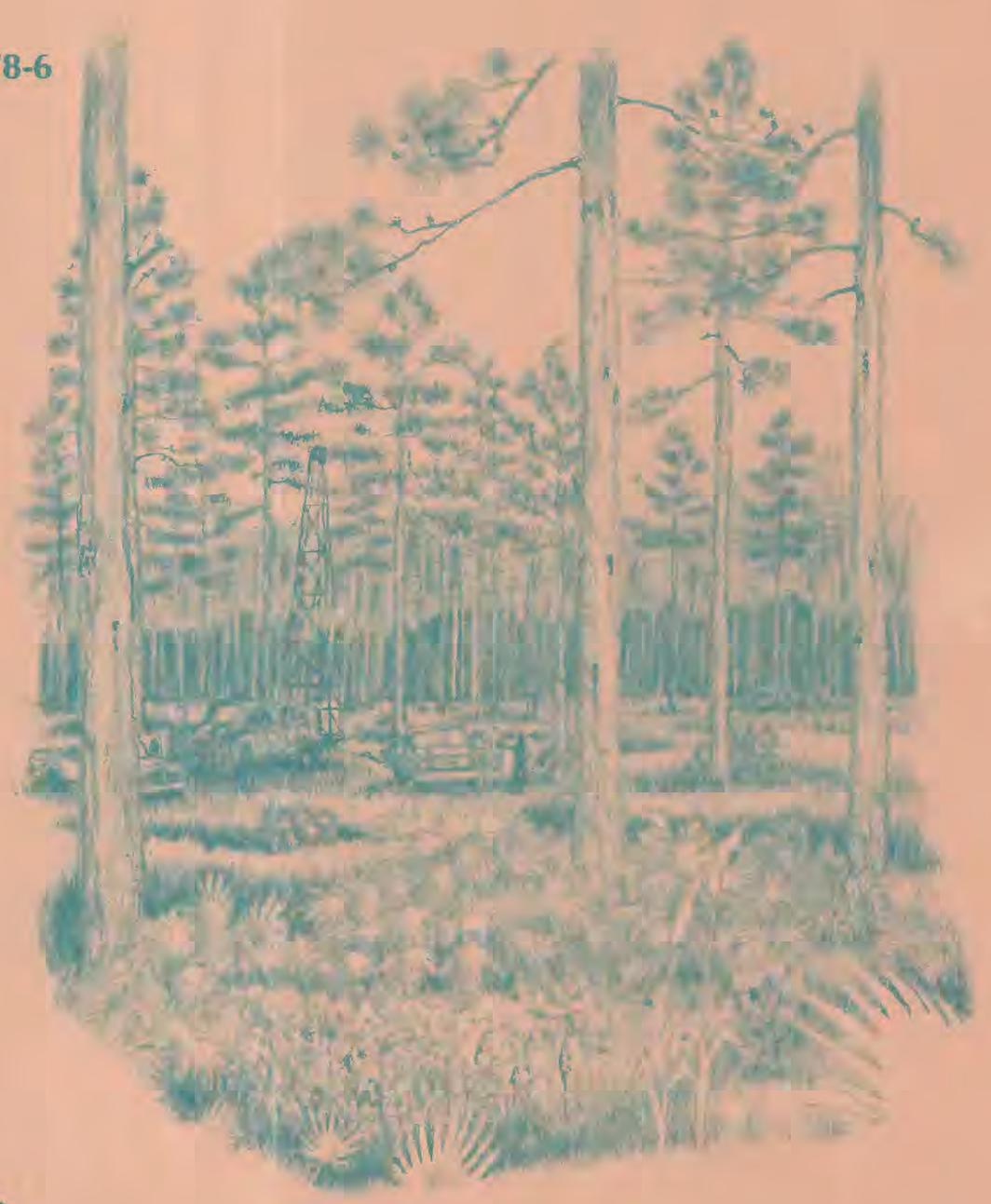

U.S. BUREAU OF LAND MANAGEMENT

U.S. BUREAU OF MINES

U.S. FOREST SERVICE 

IMPACT OF POTENTIAL PHOSPHATE MINING ON THE

HYDROLOGY OF OSCEOLA NATIONAL FOREST, FLORIDA

By James A. Miller, Gilbert H. Hughes, Robert W. Hull,

John Vecchioli, and Paul R. Seaber

U.S. GEOLOGICAL SURVEY

Water-Resources Investigations 78-6

Prepared in cooperation with

U.S. BUREAU OF LAND MANAGEMENT

U.S. BUREAU OF MINES

U.S. FOREST SERVICE

February 1978 


\section{UNITED STATES DEPARTMENT OF THE INTERIOR}

CECIL D. ANDRUS, Secretary

GEOLOGICAL SURVEY

W. A. Radlinski, Acting Director

U.S. Geological Survey, Water Resources Division Suite F-240

325 John Knox Road

Tallahassee, Florida 32303 
Abstract . . . . . . . . . . . . . . . . 1

Introduction .................... 2

Purpose and scope................. 2

Previous studies. . . . . . . . . . . . . . 4

Acknowledgments ............... 5

Regional setting................... 5

Cultural features............... 5

Vegetation. . . . . . . . . . . . . 7

Physiography. . . . . . . . . . . . . . 7

Geology ................. . . 10

Climate................... 15

Hydrology . . . . . . . . . . . . . . . 17

Regional hydrologic system . . . . . . . . 17

Surface water. . . . . . . . . . . . 19

Streamflow characteristics. . . . . . . 19

Surface-water quality . . . . . . . 26

Ground water .............. . 27

Hydrogeologic units . . . . . . . . . 27

Movement of ground water. . . . . . . . 28

Fluctuations of potentiometric surfaces . . . 29

Ground-water quality. . . . . . . . . . 29

Methods of investigation ............... 33

Hydrogeology. . . . . . . . . . . . . . 33

Surface water ................. 38

Water quality ................. 38

Geology and hydrology of Osceola National Forest . . . . . . 38

Hydrologic system of the forest . . . . . . . . . 38

Geology ................. . . 39

General. . . . . . . . . . . . . 39

Stratigraphy .............. . 40

Eocene Series .. . . . . . . . . 40

General. ............ . 40

Ocala Limestone. . . . . . . . . . 40

Miocene Series............. 42

Hawthorn Formation .. . . . . . . 42

Pleistocene-Holocene Series........ 47

Surface water ................. 48

Drainage basins. . . . . . . . . . . . 48

Streamflow characteristics . . . . . . . 48

Surface-water quality. . . . . . . . . . 56

Ground water. . . .............. 63

Hydrogeologic units. . . . . . . . . . 63

Surficial aquifer. . . . . . . . . . 65

Hawthorn confining unit. . . . . . . . . 72

Floridan aquifer............. 75

Aquifer tests. . . . . . . . . . . 89 
Geology and hydrology of 0sceola National Forest--Continued Ground water--Continued

Aquifer tests--Continued

Well locations and instrumentation . . . . . 89

Methods of analysis and test results . . . . 89

Floridan test . . . . . . . . . . 92

Hawthorn test ........... 93

Laboratory and extensometer results. . . . . 94

Evaluation of Floridan aquifer test results. . . 94

Water budget ................. 96

Hydrologic effects of current phosphate industry operations

in Hamilton County. . . . . . . . . . . . . . . 99

Phosphate industry operations . . . . . . . . 99

Mining and beneficiation. ........... 99

Chemical processing . . . . . . . . . . 101

Water uses and activities ........... 102

Effects of phosphate industry operations on streamflow . . 103

Effects of phosphate industry operations on surface

water quality. . . . . . . . . . . . . 108

Effects of phosphate industry operations on ground water . 123

Potential phosphate industry operations in Osceola National

Forest. . . . . . . . . . . . . . . . . 124

General. . . . . . . . . . . . . . 124

Summary of mining plan ............... 124

Summary of water demands . . . . . . . . . . 126

Use of water. . . . . . . . . . . . 126

Quality of water. ............. 126

Sources of water. . . . . . . . . . . 126

Losses of water.............. . . 127

Water balance . . . . . . . . . . . . 127

Potential impact of phosphate mining and beneficiation opera-

tions on the hydrologic system of Osceola National Forest and

environs. . . . . . . . . . . . . . . . 128

Effects on surface water .............. 128

Water budget of the potential phosphate industry

operations. . . . . . . . . . . . . 128

Distribution of phosphate-ore deposits. . . . . . 129

Streamflow characteristics. . . . . . . . 130

Surface-water quality ............ 133

Effects on ground water. .............. . 137

Potentiometric surfaces . . . . . . . . . 137

Surficial aquifer. . . . . . . . . 137

Hawthorn confining unit. . . . . . . . 138

Floridan aquifer............ 138

Ground-water quality . . . . . . . 147 
Potential impact of phosphate mining and beneficiation operations on the hydrologic system of Osceola National Forest and environs--Continued

Effects on ground water--Continued

Potentiometric surfaces--Continued

Ground-water quality--Continued

Surficial aquifer. . . . . . . . . 147

Hawthorn confining unit. ........ 147

Floridan aquifer............. 148

Upward movement of poor quality water . . 148

Introduction of contaminants by way of sinkholes ............ . 149

Downward movement of potential leachate . 149

Potential for sinkhole development . . . . . . . . 149 Summary . . . . . . . . . . . . . . . . 151 References................... 155 
1. Map showing location of Osceola National Forest, Florida, the four-county area, and weather stations discussed in this report. .............. . 3

2. Map showing physiographic divisions of Baker, Columbia, Hamilton, and Suwannee Counties, Florida. . . . . . 9

3. Geologic map of northeast Florida . . . . . . . . . 12

4. Map showing structural features and generalized phosphate distribution in Florida . . . . . . . . 13

5. Bar graphs showing - A, Average monthly rainfall at Lake City, 1941-70; B, Average monthly evaporation from standard Class A pan at Lake City, 1966-75 . . . 16

6. Map showing average annual lake evaporation . . . . 18

7. Map showing drainage basins in part of north Florida and south Georgia, and surface-water stations for which records are used for this study . . . . . . . 20

8. Graph showing magnitude and frequency of annual minimum 30-day average flow at selected gaging stations on Suwannee River. . . . . . . . . . . . . . 24

9. Graph showing magnitude and frequency of annual minimum 30-day average flow at four gaging stations in St. Marys River basin... . . . . . . . . . 25

10. Map showing the potentiometric surface of the Floridan aquifer in northeast Florida and southeast Georgia in December 1973. . . . . . . . . . . . . . 30

11. A, Hydrograph of we11 14 tapping the Floridan aquifer at Lake City; B, Graph of cumulative departure from the average annual rainfall at Lake City, 1947-76 . . . 31

12. Map showing location of wells from which hydrologic, geologic, and geophysical data were obtained. . . . . 34

13. Map showing structural surface of the Ocala Limestone

14. In Osceola National Forest. . . . . . . . . . . . 41 Map showing structural surface of the Hawthorn Formation in Osceola National Forest . . . . . . . . 43

15. Map showing thickness of the Hawthorn Formation in Osceola National Forest . . . . . . . . . . . . 44

16. Map showing drainage basins, phosphate lease application areas within Osceola National Forest, and three gaging stations used for this study . . . . . . . . 49

17. Bar graphs showing - A, Monthly discharge of Middle Prong St. Marys River at Taylor, October 1955 to September 1967; B, Monthly rainfall at Lake City, 1955-67 . . . . . . . . . . . . . . . . 51

18. Graph showing relation between annual discharges of Middle Prong St. Marys River at Taylor and St. Marys River near Macclenny, 1955-67 water years . . . . . 52 
Figure

Page

19. Graph showing yearly discharge at two gaging stations in St. Marys River basin . . . . . . . . . .

20. Graphs showing daily discharge of principal streams draining Osceola National Forest, April 1, 1976 to January 31,1977 . . . . . . . . . . . 54

21. Graphs showing relation of dissolved solids sum and residue, and total organic carbon to discharge of Deep Creek near Suwannee Valley. . . . . . . . . 62

22. Map showing thickness of the surficial aquifer in Osceola National Forest. . . . . . . . . . . 66

23. Map showing generalized configuration of the water table in Osceola National Forest . . . . . . . . . 67

24. Hydrographs of wells that tap the surficial aquifer. . 25. Map showing thickness of the Hawthorn confining unit in Osceola National Forest . . . . . . . . . . 73

26. Hydrograph of well $3 B$ that taps a sand near the middle of the Hawthorn confining unit . . . . . . . 76

27. Map of the potentiometric surface of the Floridan aquifer, January 15, 1977. . . . . . . . . 80

28. Map of the potentiometric surface of the Floridan aquifer, November 10,1976 . . . . . . . . 81

29. Hydrographs of wells that tap the upper part of the Floridan aquifer...............

30. Graph showing comparison of stage of Suwannee River with water levels in three wells tapping the Floridan aquifer in Osceola National Forest . . . . . . . . 85

31. Sketch showing locations of wells at aquifer test site. 90

32. Section showing generalized geology, well consturction, and static water levels at aquifer test site . . . . 91

33. Map showing drainage basins and areas of phosphate mining, Hamilton County, Florida . . . . . . . 100

34. Graph showing daily discharge of Swift Creek at Facil, May 20, 1976 to January 31,1977 . . . . . . . 105

35. Graph showing daily discharge of Rocky Creek near Belmont, May 20, 1976 to January 31, 1977, and periodic discharge measurements of Hunter Creek near Belmont. • 106

36. Map showing locations of sampling sites and selected analyses of samples collected October 18 and 19, 1976, at phosphate industry operations in Hamilton County, Florida. . . . . . . . . . . . . . . . 119

37. Schematic diagram showing location of chemical sampling sites in and around the Hamilton County phosphate industry operations and relation of sites to individual flow systems and receiving streams . . . . . . 120

38. Map showing layout of two potential mining units in 125 
39. Map showing location of proposed plant sites and contact between unconfined and confined parts of the Floridan aquifer . . . . . . . . . . . .

40. Graph showing relationship of drawdown with distance from a group of wells pumping 8,200 gallons per minute from the Floridan aquifer, for 180 days, assuming a leakance of $5.7 \times 10^{-6}$ per day ...........

41. Graph showing relationship of drawdown with distance from a group of wells pumping 8,200 gallon per minute from the Floridan aquifer, for 180 days assuming nonleaky aquifer conditions.............

42. Graph showing relationship of steady-state drawdown with distance from a group of wells pumping 6,000 gallons per minute from the Floridan aquifer, assuming a leakance of $5.7 \times 10^{-6}$ per day . . . . . . . 144

43. Graph showing relationship of drawdown with distance from a group of wells pumping 6,000 gallons per minute from the Floridan aquifer, for 11,000 days (30 years), assuming nonleaky aquifer conditions ........

\section{TABLES}

Table

1. Population and land use in Baker, Columbia, Hamilton, and Suwannee Counties, Florida . . . . . . . .

2. Water usage during 1975 in Baker, Columbia, Hamilton, and Suwannee Counties, Florida . . . . . . . 8

3. Geologic units in Baker, Columbia, Hamilton, and Suwannee Counties, Florida, and their hydrogeologic character. . . . . . . . . . . . . . Surface water stations used for this study ...... 21

5. Data from wells in and near the Osceola National

6. Drainage basins within Osceola National Forest ... 50 Forest . . . . . . . . . . . . . 35

7. Summary of selected chemical analyses of water from streams draining 0sceola National Forest . . . . . . 57

8. Summary of selected dissolved trace-element analyses of water from streams draining Osceola National Forest

9. Generalized description of hydrologeologic units in Osceola National Forest. . . . . . . . . . . 64

10. Selected chemical analyses of water from the surficial aquifer in Osceola National Forest . . . . . . . 70

11. Selected dissolved trace-element analyses of water from the surficial aquifer in Osceola National Forest. 
12. Cation exchange capacity of core samples from selected lithologic units at well 2V. . . . . . . . . . .

13. Selected chemical analyses of water from the Hawthown confining unit in Osceola National Forest. . . . . .

14. Selected dissolved trace-element analyses of water from the Hawthorn confining unit in Osceola National Forest . . . . . . . . . . . . . . . . .

15. Selected chemical analyses of water from the Floridan aquifer in Osceola National Forest . . . . . . . .

16. Selected dissolved trace-element analyses of water from the Floridan aquifer in 0sceola National Forest.

17. Results of 1aboratory tests and of the extensometer

18. Summary of water needs and systems in a phosphate data analyses. . . . . . . . . . . . . . 95

19. Selected chemical analyses of water from streams in and adjacent to phosphate mining areas in Hamilton County .. . . . . . . . . . . . . . . .

20. Selected trace-element analyses of water from streams in and adjacent to phosphate mining areas in Hamilton County . . . . . . . . . . . . . . . . .

21. Measured and estimated discharges and dissolved solids residue loads and concentrations, Hunter Creek near Belmont, Florida, August 4 and 30, 1976. . . . . .

22. Selected chemical analyses of waters from Hunter Creek and the hydraulic system at the phosphate industry operations in Hamilton County. . . . . . . . . . 135

23. Comparison of average concentrations of selected constituents in natural flow of Deep Creek, in effluent from phosphate mining-beneficiation operations, and in estimated Deep Creek mixed flow. . . . 136 

IMPACT OF POTENTIAL PHOSPHATE MINING ON THE

HYDROLOGY OF OSCEOLA NATIONAL FOREST, FLORIDA

By

James A. Miller, Gilbert H. Hughes, Robert W. Hull, John Vecchioli, and Paul R. Seaber

\section{ABSTRACT}

Osceola National Forest is a nearly flat, poorly drained, 245square mile area in Columbia and Baker Counties, Florida. Phosphate deposits underlie much of the western part of the forest. The impact of the potential mining on the hydrologic system of the forest was evaluated preparatory to consideration by the U. S. Department of the Interior of issuance of mining leases on the federally-owned land.

The forest is underlain by at least a 2,500-foot thick sequence of Atlantic Coastal Plain sediments of Early Cretaceous to Holocene age. The phosphate deposits occur near the top of the sequence in the Hawthorn Formation of middle Miocene age which overlies and confines the major aquifer used as a source of ground water throughout the northern Floridasouthern Georgia area. This major aquifer, known in Florida as the Floridan aquifer, consists in the area of the forest of carbonate rocks of Paleocene to 1ate Eocene age totaling about 1,700 feet in thickness. Unconsolidated post-Miocene sand deposits and sands of the upper part of the Hawthorn Formation comprise an unconfined aquifer, called the surficial aquifer. Although little used as a water-supply source in this area, the surficial aquifer supports the dry-weather flow of streams that drain the forest.

Rainfall on the forest averages 54 inches per year of which about 39 to 40 inches are evapotranspired and 11 to 13 inches are discharged by the small sluggish streams draining the area. One inch or less percolates down to recharge the Floridan aquifer. There is approximately 80 feet of head loss between the altitude of the water table and the potentiometric surface of the Floridan, due largely to the low vertical hydraulic conductivity of the Hawthorn strata.

A comparison of hydrologic conditions in 0sceola National Forest with those in an area in nearby Hamilton County, where phosphate mining and ore processing have been ongoing since 1965, facilitated assessment of hydrologic effects of potential phosphate industry activities in the forest, assuming similarity of operations. Information from the Hamilton County area coupled with data on geologic and hydrologic conditions obtained in the forest area led to the following predicted effects:

1) Flow characteristics of the streams draining the forest would be changed because of shifting of basin divides, interbasin transfer of water, and change in surface conditions. But, except for the stream(s) receiving effluent from the phosphate industry operations, the overall effects on streamflow would be small.

2) Average flow of the effluent-receiving stream would increase about 40 percent, due to plant releases consisting largely of water pumped from the Floridan aquifer. Much higher sustained low flows would result from the plant releases. 
3) After mining ceases, streamflow characteristics would return to virtually pre-mining conditions.

4) The effluent-receiving stream(s) would have average concentrations of dissolved solids, particularly sulfate, phosphorous, nitrogen, and fluoride, that would be notably higher than under natural conditions. Suspended-sediment concentrations would also increase. However, the increased average concentrations would not exceed maximum contaminant levels for drinking water, except perhaps for fluoride. Radium-226 concentrations probably would not be increased above natura1 levels.

5) The position and configuration of the water table in the reconstituted surficial aquifer would reflect in a subdued way the new land surface created by mining, but, in general, would approximate the configuration under natural conditions. Any change in the groundwater quality of the surficial aquifer would most likely be restricted to the mining area.

6) Changes in the quality of water in the Floridan aquifer probably would not be detectable, providing plant effluents were not discharged to Falling Creek which recharges the Floridan through a sinkhole outside of the forest.

7) Lowering of the Floridan potentiometric surface because of pumping for ore mining and beneficiation would be less than five feet at Lake City, White Springs, and Taylor. Although the lowered potentiometric surface might reduce ground-water discharge to the Suwannee River somewhat, the average flow of the river below White Springs would probably be unaffected because of the increased discharge of its tributary stream into which plant effluent was discharged.

8) Other hydrologic changes might occur in the vicinity of the potential phosphate industry operations depending on the actual mining, processing, waste disposal, and land reclamation practices used.

\section{INTRODUCTION}

\section{Purpose and Scope}

Because of uncertainties about the hydrologic consequences of potential phosphate mining in Osceola National Forest, located in Columbia and Baker Counties in north-central Florida, (fig. 1) additional waterresource information was deemed necessary by the Secretary of the Interior before a Departmental decision on pending preference right lease applications could be made. In order to obtain the needed additional information, the Secretary directed the U. S. Geological Survey to conduct a two-year investigation of the area and to report the findings by December 1, 1977. The U. S. Fish and Wildlife Service was directed to conduct a concurrent study to determine the effects of the potential mining on endangered, rare, or threatened species in the forest. 


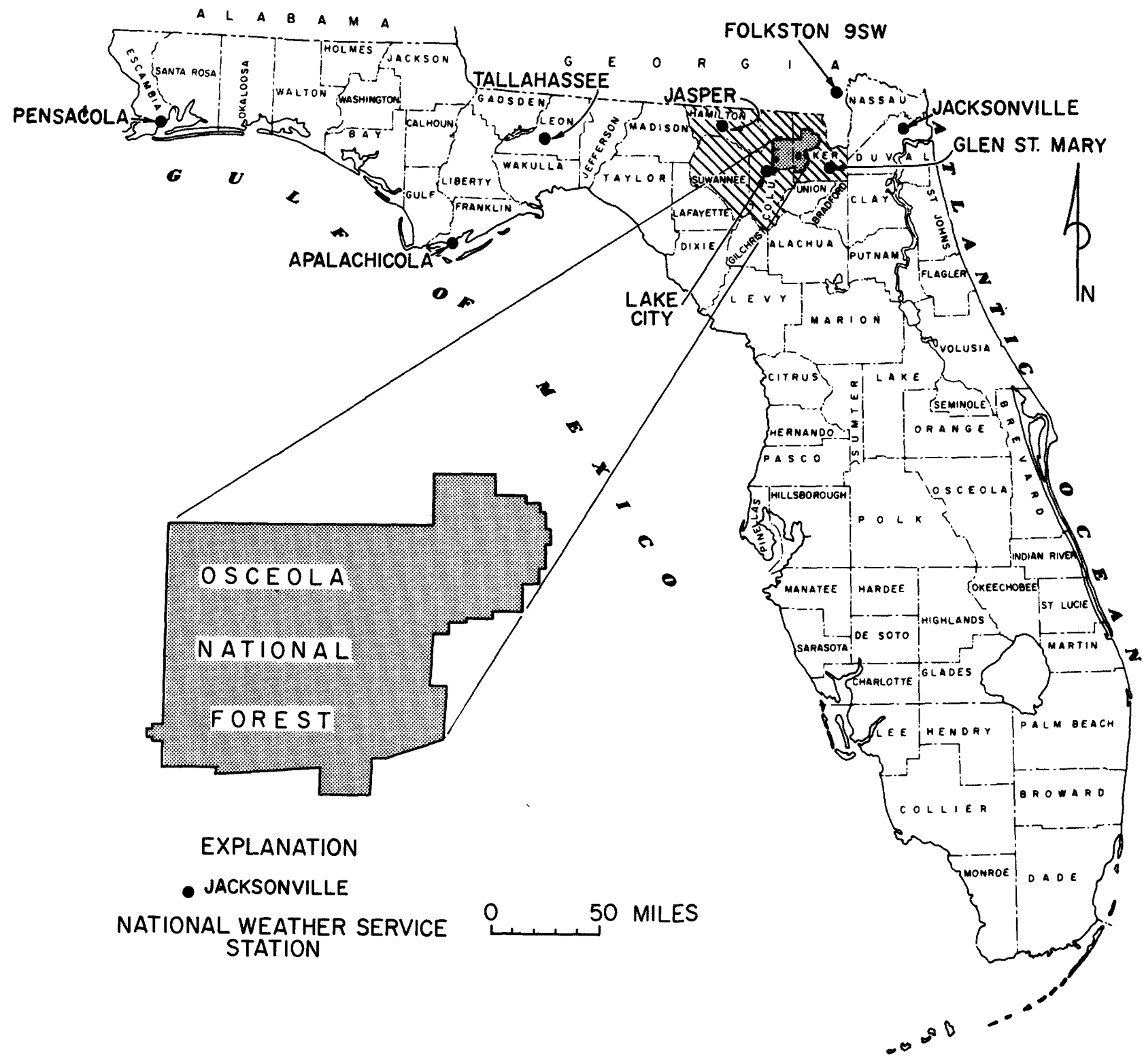

FIGURE 1.--LOCATION OF OSCEOLA NATIONAL FOREST, FLORIDA, THE FOUR-COUNTY AREA, AND WEATHER STATIONS DISCUSSED IN THIS REPORT. 
The primary purpose of this investigation was to determine the characteristics of the hydrologic system of Osceola National Forest and surrounding areas, with concentration, in a regional sense, on the fourcounty area of Baker, Columbia, Hamilton, and Suwannee Counties, in order to provide the understanding needed to predict the impact of the potential phosphate industry operations in the forest on the natura1 hydrologic system. Specifically, the investigation sought to define: 1) the geologic environment; 2) the relevant ground- and surface-water hydrology and their interrelation, including water-quality considerations; and 3) the effects of phosphate mining, processing, and waste disposal on the hydrologic system of Osceola National Forest. The investigation, begun December 1975, involved test drilling, implementation of a hydrologic monitoring network, water-quality sampling, comprehensive aquifer tests, and literature study. Data acquired through these activities are used in this report to evaluate the effects that phosphate industry operations might have on the hydrologic system of the forest and environs. Some information is presented on the hydrologic effects of current mining activities on nearby private land in Hamilton County as a basis for evaluating potential changes to the hydrology of the forest should mining be permitted there.

\section{Previous Studies}

Several reports have been published that include data on the geology and ground-water resources of Columbia, Baker, Hamilton, and Suwannee counties. Matson and Sanford (1913) discussed the general geology and water supply of each individual county. Reports by Mossom (1926), Cooke (1945), Applin (1951), Applin and App1in (1944, 1967), and Puri and Vernon (1964) include information on the surface and subsurface geology of these counties. Stringfield $(1936,1966)$ and Cooper, Kenner, and Brown (1953) described the regional hydrology of the area. The chemical character of the ground water in the four counties was published in reports by Collins and Howard (1928) and Black and Brown (1951). Reconnaissance reports on Columbia County by Meyer (1962) and on Baker County by Leve (1968) discussed the geology and ground-water resources of those counties. The phosphate deposits of the area were discussed by Espenshade and Spencer (1963). Numerous statewide maps prepared by the U. S. Geological Survey and published as part of the Map Series of the Florida Bureau of Geology present a regional picture of the geology and hydrology of the area. An Environmental Impact Statement (U. S. Department of Interior, 1974) dealt in general with the geology and hydrology of columbia and Baker counties, and in particular with Osceola National Forest on the basis of sparse regional information. Little work has been published that has a direct bearing on the relation between phosphate industry operations and water resources in northern Florida, but several reports (U.S. Environmental Protection Agency, 1974, 1975a; Guimond and Windham, .1975) have described certain aspects of the environmental impact of phosphate mining in central and southern Florida. Irwin and Hutchinson (1976) tabulated radium-226 data from surface water and ground water in northern, central, and southern Florida. 
Appreciation is expressed to the residents of the area who contributed information and permitted access to wells so that geophysical or water-level data could be obtained. Officials of Occidental Chemical Company, White Springs, Florida, discussed pertinent phosphate industry operations with project personnel and allowed sampling in and near an operating phosphate mine and plant. Background information, field office space, and logistical assistance were furnished by the Suwannee River Water Management District. Test-hole drilling and well construction were done by U. S. Army Corps of Engineers personnel.

The U. S. Forest Service supplied maps, advice, and assistance in locating drilling sites and assisted in other phases of the investigation at field and office level. Working relationships were established with the U. S. Bureau of Mines, U. S. Fish and Wildlife Service, and U. S. Bureau of Land Management and these contacts provided much helpful discussion and comment.

Colleagues of the U. S. Geological Survey who contributed to the investigation include William F. Bruns, Reston, Virginia, and Garth E. Ghering, Joseph W. Reid, Jr., and Richard F. Stanley, al1 of Lakewood, Colorado, who constructed and installed the complex instrumentation used for the extensive and detailed aquifer testing. Francis S. Riley of Lakewood, Colorado, and Stavros S. Papadopulos of Reston, Virginia, analyzed the aquifer-test data and contributed to the parts of this report dealing with aquifer-test methods and results. The aquifer test was designed by Hilton H. Cooper, Jr., and M. I. Rorabough.

\section{REGIONAL SETTING \\ Cultura1 Features}

The 245 square miles comprising 0sceola National Forest are divided approximately equally by the county line separating Columbia and Baker Counties in northeast Florida. The forest lies in the upper reaches of the Suwannee and St. Marys River basins which come under the jurisdiction of the Suwannee and St. Johns River Water Management Districts, respectively. The Suwannee River is also under the jurisdiction of the Suwannee River Authority.

Suwannee, Hamilton, Columbia, and Baker Counties are predominantly rural with 59 percent of the population residing outside of city limits (table 1). Forty-five percent of the urban population lives in Lake - City, a major crossroad of transportation near the southwestern corner of the forest (table 1).

Income for the region is derived primarily from light industry and agriculture for which timber, tobacco, pecans, peaches, watermelons, nursery plants, and livestock are of major importance. Industries include: agribusiness and wood processing; manufacturing of wood products, 


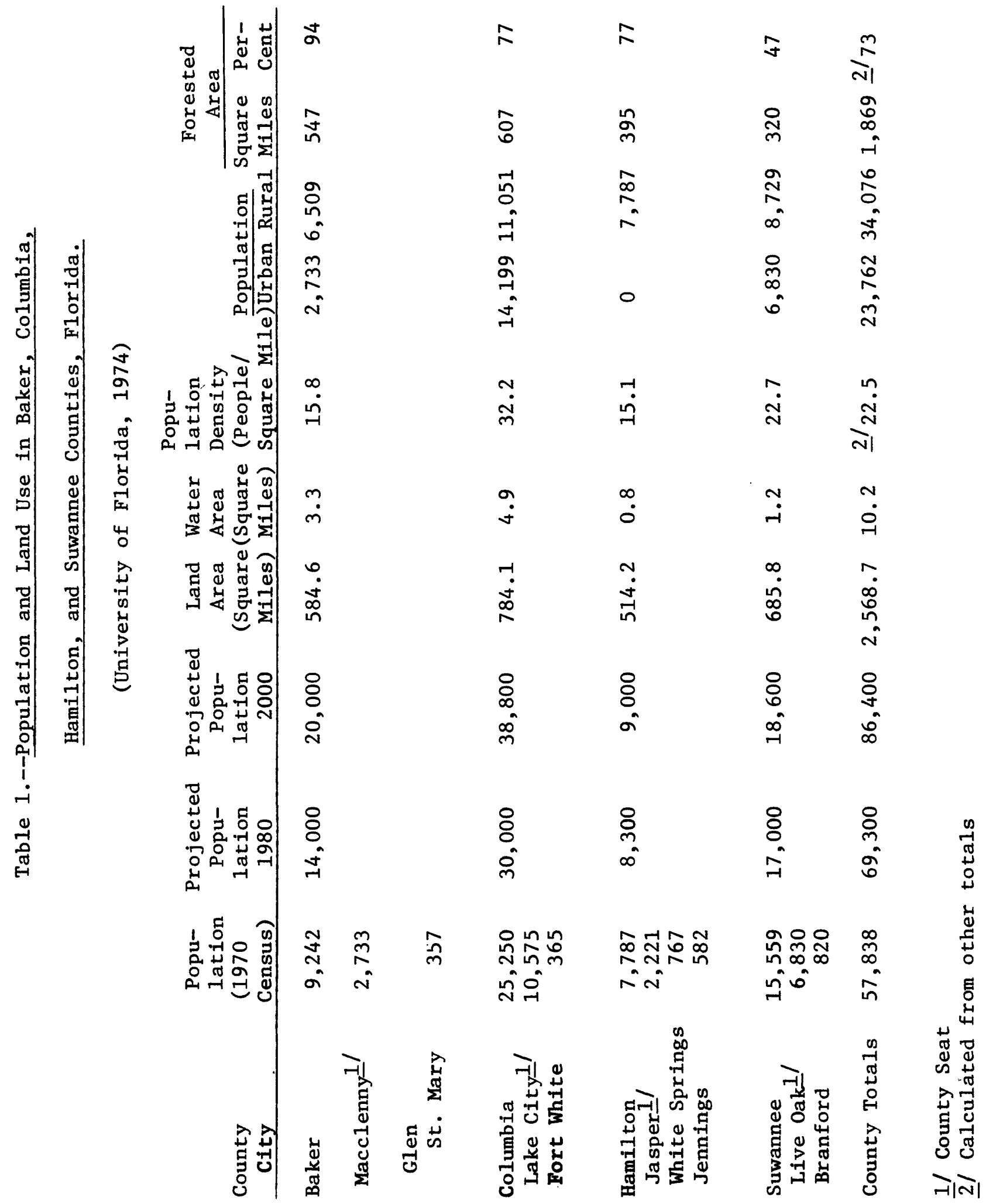


machinery, tools, clothing, mobile homes, food products, and chemicals; and the phosphate-rock industry (University of Florida, 1974, p. A1-A228).

About 73 percent of all land in the four-county area is forested as classified by the University of Florida (1974, p. 353). Most of the remaining land is utilized for crops. The area contained 10.2 square miles classified as water-covered in 1970; however, mining of phosphate rock in Hamilton County has increased this water-covered area.

Total water use by man in the four-county area in 1975 was about 58 million gallons per day, of which 96 percent was obtained from ground water (table 2). This amount excludes water recycled from settling ponds by the phosphate industry in Hamilton County. Ground-water withdrawals were largest in Hamilton County where the phosphate industry pumped 54 percent of all ground water withdrawn in the four-county area. The second largest use, 19 percent, was for irrigation in Columbia County. Amounts of water currently used by man in this area are only a fraction of the available water resources.

\section{Vegetation}

The Suwannee and St. Marys River basins are covered 83 percent by forest and 13 percent by crop and pasture land (U. S. Department of Agriculture, 1976, p. 3-20b). These basins contain many freshwater swamps. Avers and Bracy (no date) described in detail the Osceola National Forest vegetation which is typical of the entire forest area of both river basins, except for differences in distribution and timbermanagement practices. The vegetation has been categorized by Avers and Bracy into four general types: (1) pine palmetto flatwoods, (2) cypress swamps, (3) bay swamps, and (4) creek swamps. Pine palmetto flatwoods cover about 68 percent of the forest area. Cypress swamps make up about 16 percent of the forest vegetation by area. This vegetative unit occurs mainly as domes within the flatwoods. Bay swamps, which cover about 15 percent of the forest, occur as irregularly shaped swamps or stringer bays. Creek swamps account for about 1 percent of the forest and occur along Deep Creek and Middle Prong St. Marys River.

\section{Physiography}

The four-county area lies entirely within the Atlantic Coastal Plain physiographic province. The altitude is largely controlled by a series of marine terraces which formed at different elevations in the area during Pleistocene time. Cooke (1945) subdivided the area into the Coastal Lowlands and the Central Highlands on the basis of altitude (fig. 2). The Coastal Lowlands are areas that lie below an altitude of 100 feet. They include part of the floodplains of the Suwannee, Santa $\mathrm{Fe}$, and St. Marys Rivers, and the Wicomico and lower terraces. The Coastal Lowlands zone is underlain by limestone bedrock covered with a thin veneer of alluvial and swamp deposits of sand and clay. The proximity of the limestone to the surface has resulted in the development of karst topography with numerous sinkholes and a well developed underground drainage; consequently, surface drainage is coarse textured. 


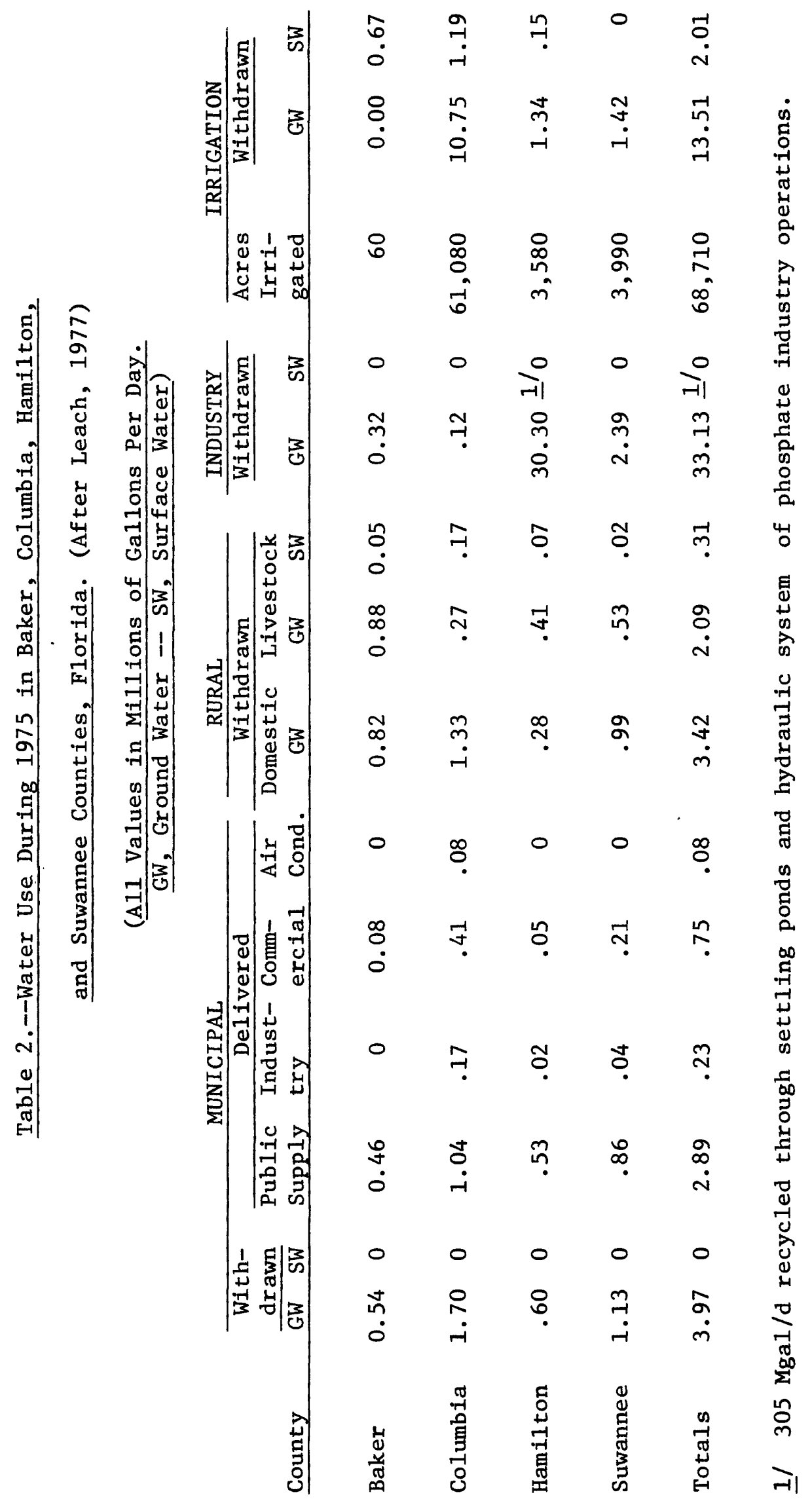




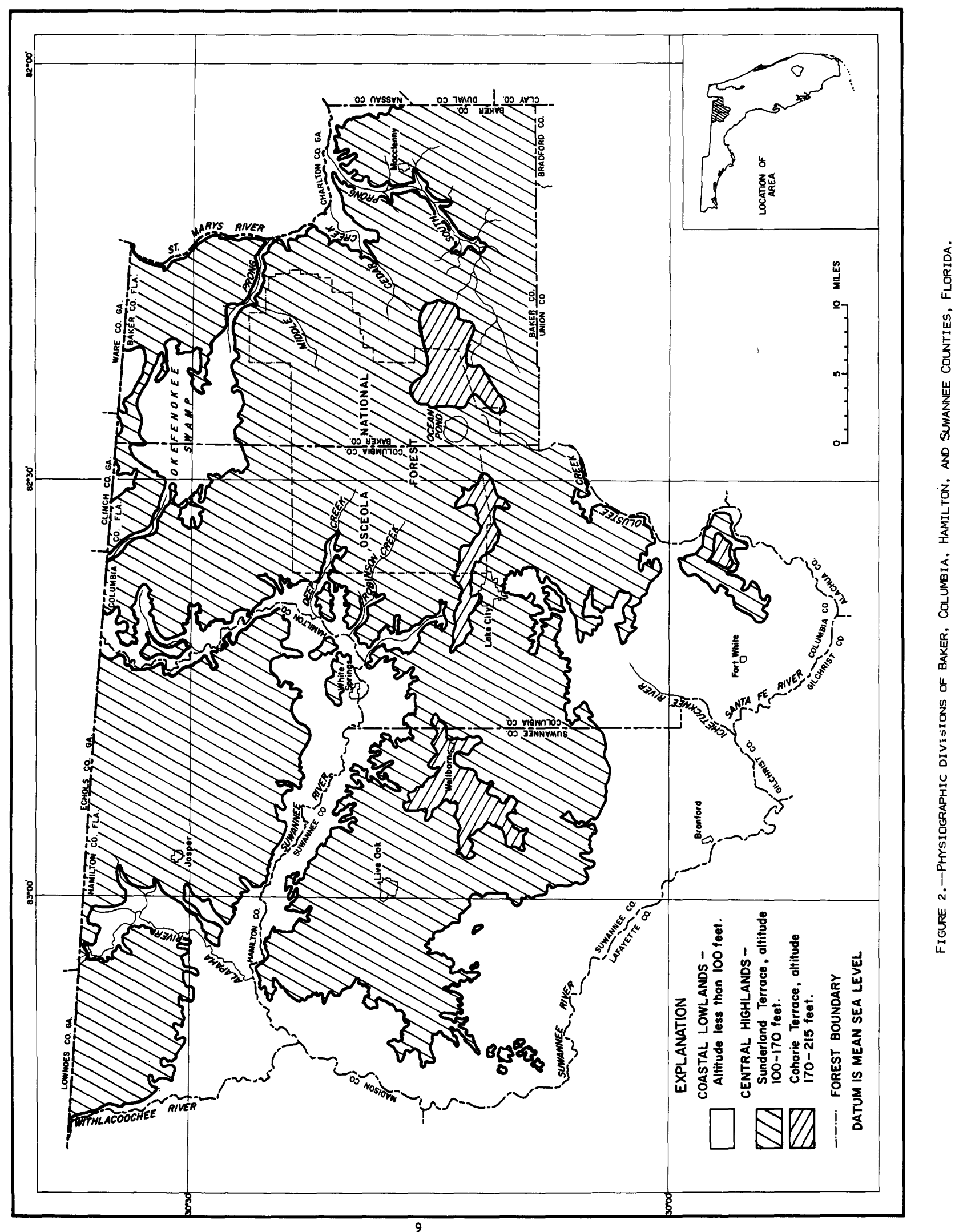


The southwestern extension of the Okefenokee Swamp occurs in the Coastal Lowlands in northern Columbia and Baker Counties. This poorly drained area is underlain by argillaceous, organic-rich, fine-grained sands. The generally sluggish surface drainage from this part of the swamp is primarily northwestward to the Suwannee River and secondarily eastward to the St. Marys River.

The remainder of the four-county area is within the Central Highlands and is characterized by a series of dissected terrace deposits developed at progressively higher altitudes. The Sunderland (altitude 170 feet) and Coharie (altitude 215 feet) terraces of Cooke (1945, p. 277-278) attain their maximum altitude as an elongate ridge extending from Live Oak in Suwannee County eastward nearly to Macclenny in Baker County (fig. 2). The ridge forms the drainage divide between the upper Suwannee River basin to the north and the Santa $\mathrm{Fe}$ River basin to the south. These terrace deposits are separated from the Coastal Lowlands by a fairly well developed scarp in southern Suwannee and Columbia Counties (White, 1970).

The Central Highlands are underlain by a thin sequence of clastic sediments of post-Miocene age. These unconsolidated sediments are separated from limestone bedrock by a thick sequence of consolidated or semi-consolidated Miocene clastic and carbonate strata. Few karst solution features are surficially evident on the Central Highlands, except at lower altitudes near the Coastal Lowlands and in the area of the scarp referred to above. Most surficially-recognizable sinkholes and other karst features occur in southern and western Suwannee and Columbia Counties, and central and western Hamilton County. Aerial reconnaissance and subsequent ground-level checking revealed no surficial evidence of sinkholes within the Osceola National Forest, although they are known to occur within a few miles of the southwestern corner of the forest.

\section{Geology}

The four-county area is underlain by a sequence of Coastal Plain sediments whose minimum thickness is 2,500 feet, as shown by deep oiltest wells (Applin and Applin, 1967). These sediments are predominantly of shallow-water origin and are composed of marine limestones, evaporites, and clays that range in age from Early Cretaceous to Holocene. They were deposited on lower and middle Paleozoic rocks that consist of flatlying black micaceous fissile shales with thin interbeds of white quartzite. Table 3, the general stratigraphic column, includes a brief description of the 1ithology, thickness, and hydrogeologic character of the geologic units underlying the area. Figure 3 is a generalized geologic map showing the distribution of the various formations in northeast Florida as recognized by the Florida Bureau of Geology (Vernon and Puri, 1964). The entire section slopes and thickens gently to the northeast and southwest from the crest of an anticlinal structural high named the Peninsular Arch by Applin (1951, p. 3). This northwestsoutheast trending positive area (fig. 4), whose axis plunges northwest 


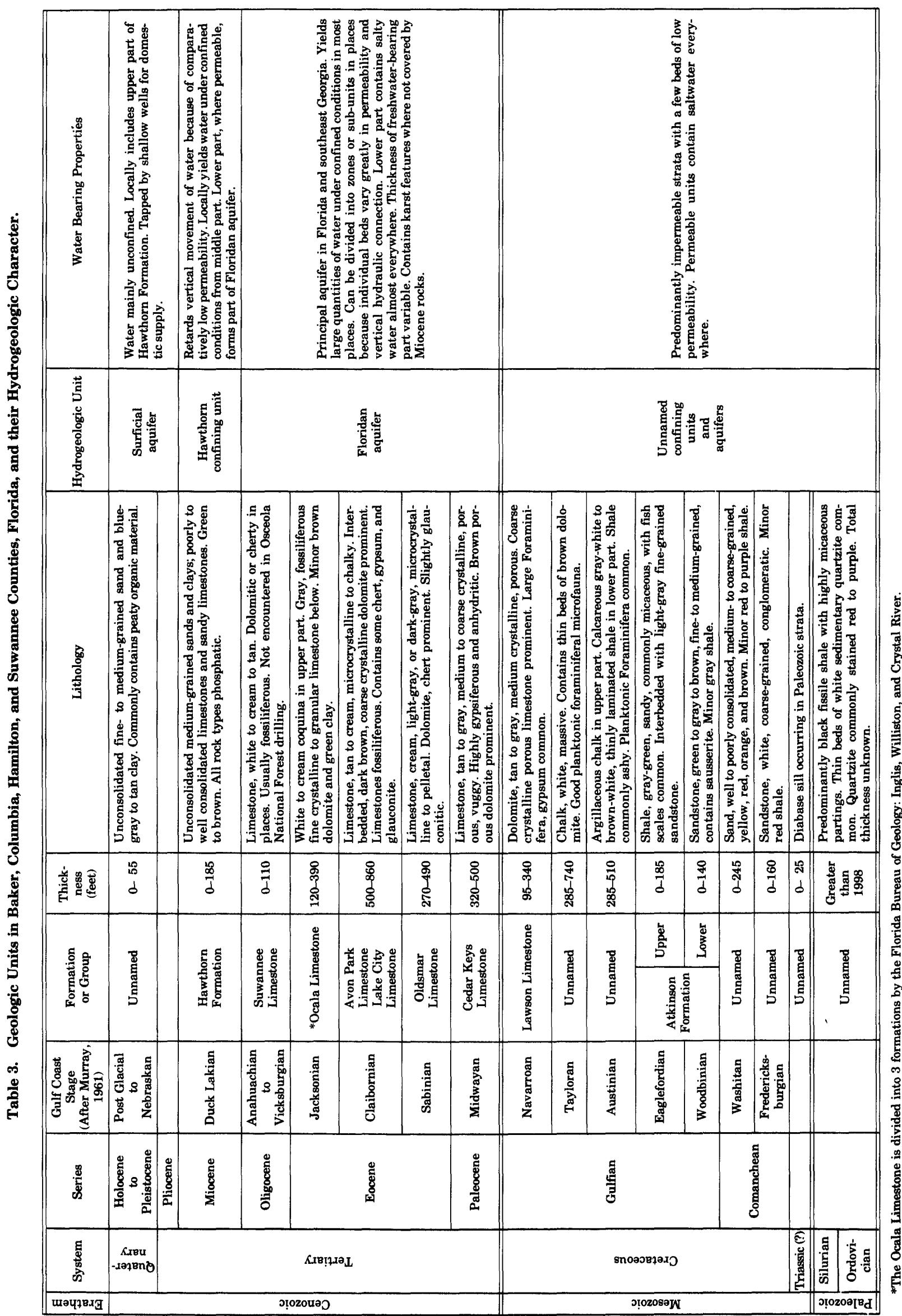




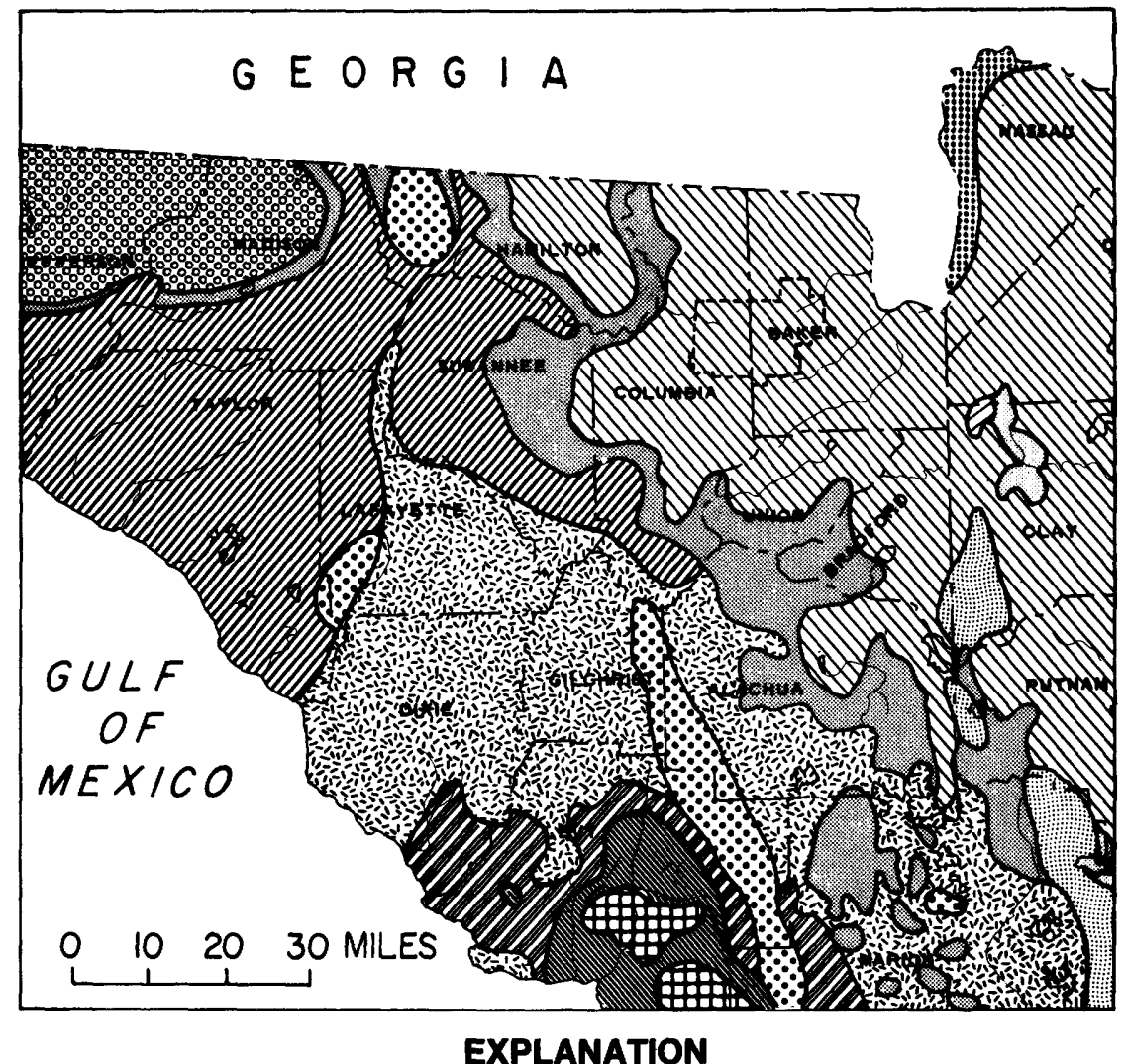

--- BOUNDARY OF OSCEOLA NATIONAL FOREST

\begin{tabular}{|c|c|c|}
\hline SERIES & STAGE & FORMATION \& MEMBER \\
\hline $\begin{array}{l}\text { HOLOCENE AND } \\
\text { PLEISTOCENE }\end{array}$ & & $\begin{array}{l}\text { Several lower marine and } \\
\text { estuarine terrace deposits }\end{array}$ \\
\hline \multirow{7}{*}{ MIOCENE } & \multirow{7}{*}{${ }^{C_{4} \mathrm{O}_{\mathrm{S}_{4}}}$} & Miccosukee Formation* \\
\hline & & Charlton Formation* \\
\hline & & Jackson Bluff Formation* \\
\hline & & Yellow River Formation \\
\hline & & Alachua Formation* \\
\hline & & Fort Preston Formation \\
\hline & & Hawthorn Formation * \\
\hline OLIGOCENE & & Suwannee Limestone * \\
\hline \multirow{4}{*}{ EOCENE } & \multirow{3}{*}{$\mathrm{JACKSON}^{*}$} & Crystal River Formation \\
\hline & & Williston Formation \\
\hline & & Inglis Formation \\
\hline & CLAIBORNE* & Avon Park Limestone * \\
\hline
\end{tabular}

Stage, formation, and member terminology is that used by the Florida Bureau of Geology. The U.S. Geological Survey recognizes those units marked with an asterisk, but the Charlton, Jackson Bluff, and Alachua Formations are considered Pliocene age.

FIGURE 3.--GEOLOGIC MAP OF NORTHEAST FLORIDA (AFTER VERNON AND PURI, 1964 ). 


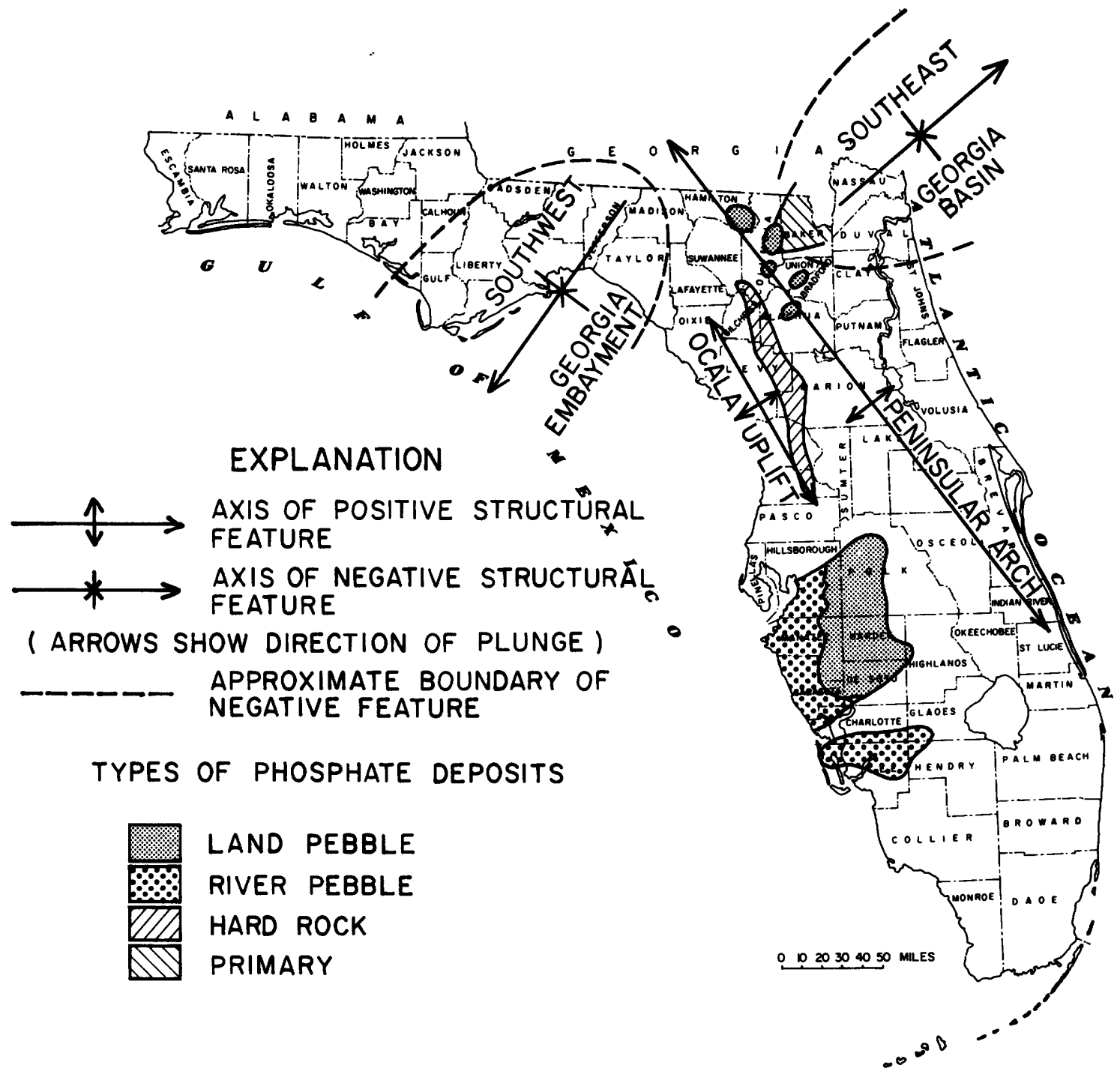

FIGURE 4.--STRUCTURAL FEATURES AND GENERALLIZED PHOSPHATE DISTRIBUTION IN FLORIDA. (PHOSPHATE INFORMATION AFTER BRITISH SULPHUR CORPORATION, 1961). 
across central Columbia and Hamilton Counties, was the dominant influence on sedimentation in northern Florida from early Mesozoic (Jurassic) until middle Late Cretaceous time (Austinian stage). Parallel to and southwest of the Peninsular Arch is a structure termed the Ocala uplift which affects the thickness and depositional patterns of middle Eocene and younger sediments. This feature is a structural entity distinct from the Peninsular Arch (Winston, 1976).

To the northeast of the four-county area, a thick sequence of Mesozoic and Cenozoic deposits occurs in a northeast-plunging syncline called the Southeast Georgia or Savannah basin (fig. 4), which was the site of more or less continuous deposition since Jurassic time (Murray, 1961, p. 96-97). The Apalachicola or Southwest Georgia embayment, located to the west, is another long-lived negative feature. This syncline, whose axis plunges southwest toward the Gulf of Mexico, has also received a continuous supply of sediments since Jurassic time. The Ocala uplift and the Southeast Georgia basin are the two structural features which have most directly affected sedimentation in the area of investigation since Eocene time.

The distribution of known phosphate deposits in Florida is shown on figure 4. These deposits have been grouped into land pebble, river pebble, hard-rock, and primary types of phosphate by the British Sulphur Corporation (1961, p. 46-50). The most extensive and the highest grade deposits are those of the land-pebble type, typified by the P1iocene Bone Valley Formation of central Florida. Land pebble phosphate is varicolored, sand to pebble-sized, usually mixed with vertebrate remains, occurs in a matrix of clay and (or) sand, and is the result of both shallow marine and terrestrial deposition. This type of phosphate underlies most of the western half of Osceola National Forest and it is the type currently (1977) being mined in Hamilton County, Florida. River-pebble phosphate is reworked land-pebble material, and occurs in the recently formed bars and valleys of present streams. River-pebble phosphate is of low grade and limited extent. Hard-rock phosphate is found as filling of erosional or solution depressions in limestone in north-central Florida. This type of phosphate is characterized by large boulders, pebbles, and plates of phosphate and (or) phosphatized limestone mixed with material of smaller size. Some of the phosphate in the hard-rock deposits is the result of partial or complete replacement of limestone by downward-percolating phosphate-rich ground water. The enriched limestone was subsequently eroded and redeposited as large clasts in topographic depressions on an older limestone surface.

A fourth type of phosphate deposit occurs beneath Baker County and eastward. This material consists of dark-brown to black, medium-to very coarse-grained sand-sized, low to high grade, primary phosphate in a matrix of water-polished quartz sand. These deposits are thought to have formed by the direct precipitation of phosphate from seawater. Similar deposits occur in the middle Miocene Pungo River Formation in North Carolina. Deposition of this type phosphate is associated with a relatively abrupt change in the slope of the floor of the basin of deposition and takes place in 300 to 600 feet of water (Miller, 1971, p. 52-57). 
The climate of the four-county area is subtropical with maximum daily temperatures at Lake City averaging about $90^{\circ} \mathrm{F}$ during summer and minimum daily temperatures averaging about $45^{\circ} \mathrm{F}$ during winter. At the major National Weather Service Offices in northern Florida--Jacksonville, Tallahassee, Apalachicola, and Pensacola (fig. 1)--the average monthly percentage of possible sunshine ranges from 50 to 70 percent (U. S. Dept. Commerce, 1972). Skies are most cloud free during Apri1-June and October-November. Average monthly relative humidities, which are lowest during spring and fall and highest during summer, range from 47 to 70 percent in the afternoon and from 79 to 93 percent in early morning. Winds vary in direction, with northerly winds prevailing during winter and southerly during summer. Average monthly wind speeds are highest in February and March ( 9 to 10 miles per hour) and lowest during July and August ( 6 to 7 miles per hour).

According to National Weather Service records (U. S. Dept. Commerce, 1975), the annual rainfall at Lake City during $1941-70$ averaged 54.14 inches, which is about equal to the regional average for the 19-county area of northeast Florida. The long-term record of rainfall at Lake City is considered herein to be representative of rainfall in Osceola National Forest. The annual rainfall at Lake City has ranged from a minimum of 29.83 inches in 1908 to a maximum of 84.47 inches in 1964 . The general distribution of rainfall within the year is shown on figure 5A. In general, about half the annual rainfall occurs from June through September, with rainfall during the other months ranging from 2 to 4 inches per month.

Summer rainfalls are mostly from late afternoon thunderstorms of relatively brief duration. The rainfall from thunderstorms may be large or small, and the amounts for any given storm generally differ greatly over relatively short distances. In Florida many rainfall stations average more than 80 thunderstorms per year, some more than 100 (U. S. Dept. Commerce, 1972 , p. 3). Winter rainfalls generally result from southward moving cold fronts and are areally more uniformly distributed and of longer duration than summer rainfalls. Exceptionally heavy rainfalls result from hurricanes or less severe tropical storms that occur sporadically in summer to early fall.

Most Florida rainfall returns to the atmosphere by evapotranspiration-a term used herein to represent the uptake of water by evaporation from soil and water surfaces and transpiration by plants. For the state as a whole, average annual evapotranspiration consumes about 39 inches of the annual rainfall. Locally, evapotranspiration varies with the evaporative demand of the atmosphere and the availability of water at or near the land surface. In swamps and marshes, where water is readily available for evaporation over most of the area most of the time, the annual evapotranspiration exceeds the statewide average. In upland areas where the surficial materials are permeable and permit high infiltration rates, and where the water table is some distance below the land surface, evapotranspiration is less than the statewide average. 


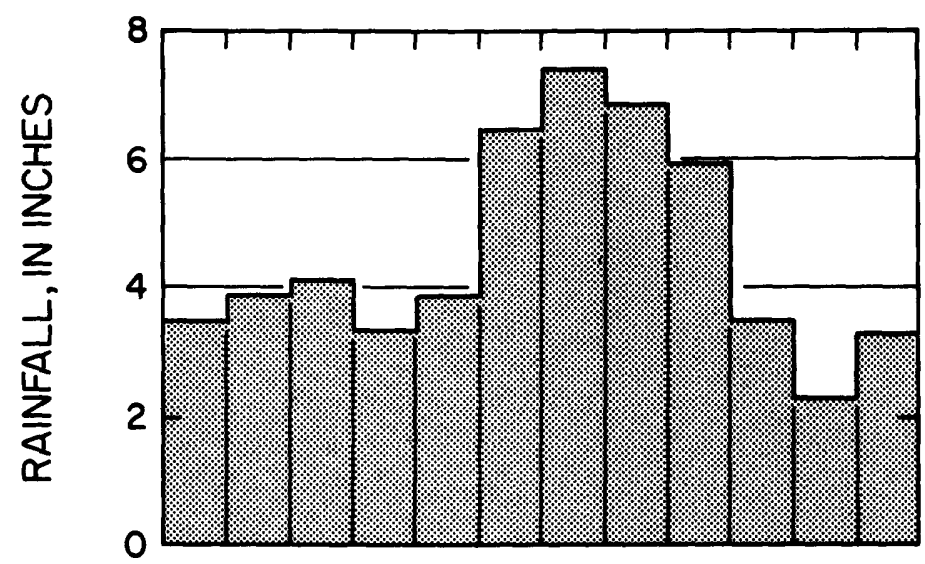

A.

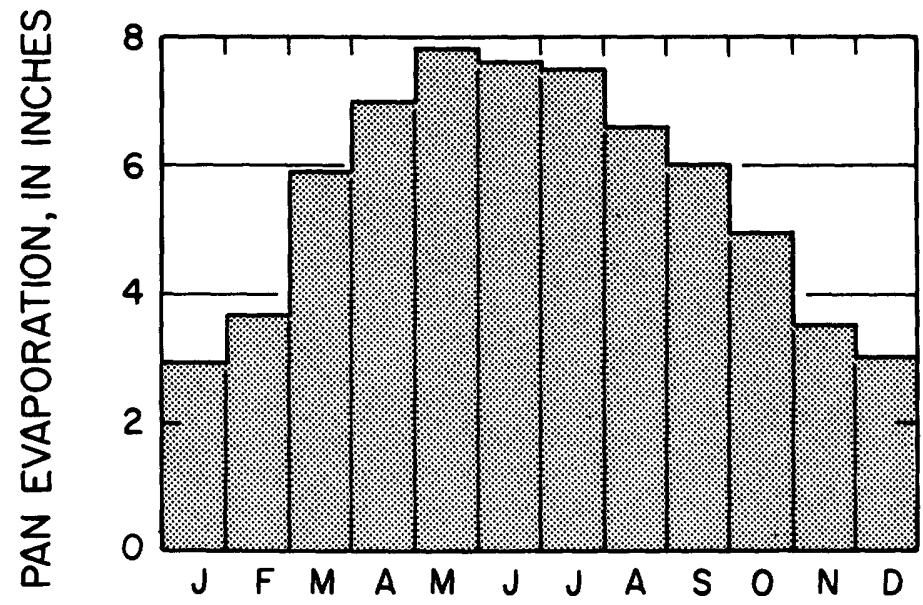

B.

FIGURE 5.--A, AVERAGE MONTHLY RAINFALL AT LAKE CITY, 1941-70; B, AVERAGE MONTHLY EVAPORATION FROM STANDARD CLASS A PAN AT LAKE CITY, 1966-75. (DATA FROM NATIONAL WEATHER SERVICE). 
Lake evaporation has not been measured in the vicinity of Osceola National Forest or elsewhere in north Florida. Evaporation from a Class A pan has been measured at Lake City since mid-1965. During 1966-75 yearly pan evaporation at this site averaged about 66 inches and monthly pan evaporation averaged from 3 to 8 inches as shown in figure 5B. A pan-to-lake coefficient is required to estimate lake evaporation from pan evaporation, but such a coefficient has not been determined for the Lake City pan. Coefficients established for pans in other areas would not necessarily apply because even in the same general area pan evaporation can vary appreciably depending on the local exposure of the pan. The evaporation map (fig. 6) prepared by Kohler and others (1959, plate 2) indicates that in the vicinity of Osceola National Forest the average annual lake evaporation is about 46 inches. This figure is thought to be the best estimate of lake evaporation for this area and, consequently, is used herein in subsequent water-budget analyses.

Annual evapotranspiration rates have been determined for large basins in other parts of Florida. In a study of Kissimmee River basin, an area in central Florida containing extensive lakes and swamps, Langbein (1955, p. 550) determined that the annual water loss due to evapotranspiration averaged 42.5 inches during 1931-46. In Marion County, about 80 miles south of Osceola National Forest, Faulkner (1976, p. 6-1) found that evapotranspiration averaged 35 inches per year in the ground-water basin of Silver Springs. This basin is relatively free of lakes and swamps and consists mostly of a subdued karst terrane with a well developed subsurface drainage system. Evapotranspiration rates in the four-county area of investigation probably vary within the range bounded by these two values according to the nature of the terrane.

\section{Hydrology \\ Regiona1 Hydrologic System}

The hydrologic system in the four-county area of investigation has been stressed and changed by man only locally. These stresses, imposed by phosphate mining activities in Hamilton County, by irrigation in Columbia County, and by a few scattered municipalities, have had little noticeable effect on the original flow patterns and boundaries of the hydrologic system. The physical framework of the four-county area of study includes three hydrogeologic units representing two freshwater aquifers separated by a confining bed and known as, in descending order, the surficial aquifer, Hawthorn confining unit, and the Floridan aquifer. These rocks are confined at depth by poorly permeable beds containing moderately to very saline water.

The vertical boundaries of the surficial aquifer are land surface and the Hawthorn confining unit. Laterally, the surficial aquifer is bounded to the west and northwest by tributaries of the Suwannee River; to the north by the Okefenokee Swamp; to the east by the St. Marys River; and to the southeast, south, and southwest by an extensive karst area. This karst area and attendant streams such as the Suwannee and Santa Fe Rivers form the southeastern to northwestern boundaries of the 


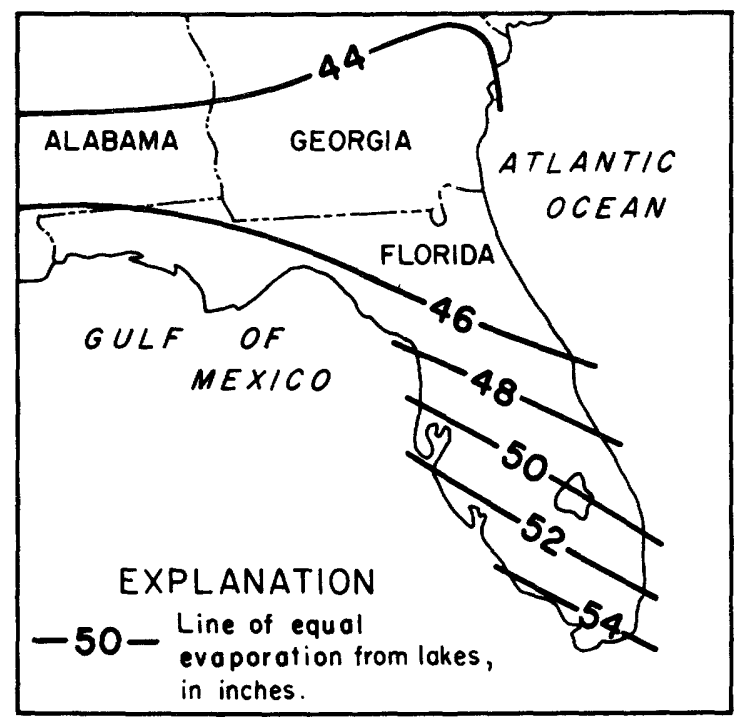

FigURE 6.--AVERAGE ANNUAL LAKE EVAPORATION (AFTER KOHLER AND OTHERS, 1959.) 
Floridan aquifer, which is bounded to the northeast and east by the Atlantic Ocean and the St. Johns River. The vertical boundaries of the Floridan are the Hawthorn confining unit above and poorly permeable Mesozoic beds below.

The surficial aquifer is composed of post-Miocene unconsolidated sand and clay and the uppermost part of the Hawthorn Formation of Miocene age which consists of phosphatic limestone, sand, and clay. The water table in the surficial aquifer lies at or near the land surface and is a subdued replica of the topography. All recharge to the surficial aquifer is from rainfall. Ground-water flow within the surficial aquifer is predominately local. The major discharge is primarily to evaporation and transpiration and secondarily to streams, lakes, and swamps. The surficial aquifer is hydraulically continuous with surface-water bodies and ground-water discharge from the aquifer supports the dry weather flow of streams. The water levels in the surficial aquifer are practically everywhere higher than those in the underlying strata; thus, some discharge occurs by downward leakage through the Hawthorn confining unit to the Floridan aquifer.

The Hawthorn confining unit consists main1y of beds of clay, sandstone, and limestone. Locally, some beds are minor aquifers.

The Floridan aquifer is composed of a thick series of carbonate strata that contains freshwater at the top and slightly to moderately saline water at the base. Ground water in the Floridan is under artesian or confined conditions where the aquifer is overlain by the Hawthorn confining unit but is largely unconfined in karst areas. The general area of Osceola National Forest is a nu11 or dividing point for regional ground-water flow in the Floridan aquifer in the four-county area. Ground water moves into the four-county area from potentiometric highs in karst areas to the south in Florida and to the north and west in Georgia. Locally, recharge to the Floridan occurs directly from rainfall in karst areas and by vertical leakage through the Hawthorn confining unit elsewhere. Some water enters the Floridan aquifer through sinkholes and some, perhaps, from the Suwannee River during periods of high stream stage. These local sources of recharge may create local potentiometric highs. Within the four-county area, the aquifer discharges locally to surface-water bodies such as the Suwannee and Santa Fe Rivers; regionally, it discharges eastward and northeastward to the Atlantic Ocean and the lower St. Johns River, and southwestward to the Gulf of Mexico. The hydrologic characteristics and physical framework of the regional hydrologic system are described in detail below.

Surface Water

Streamflow Characteristics

The major streams draining the area of investigation are the Suwannee River and the St. Marys River (fig. 7 and table 4), both of which head in the Okefenokee Swamp in Georgia. The Suwannee River flows southward, 


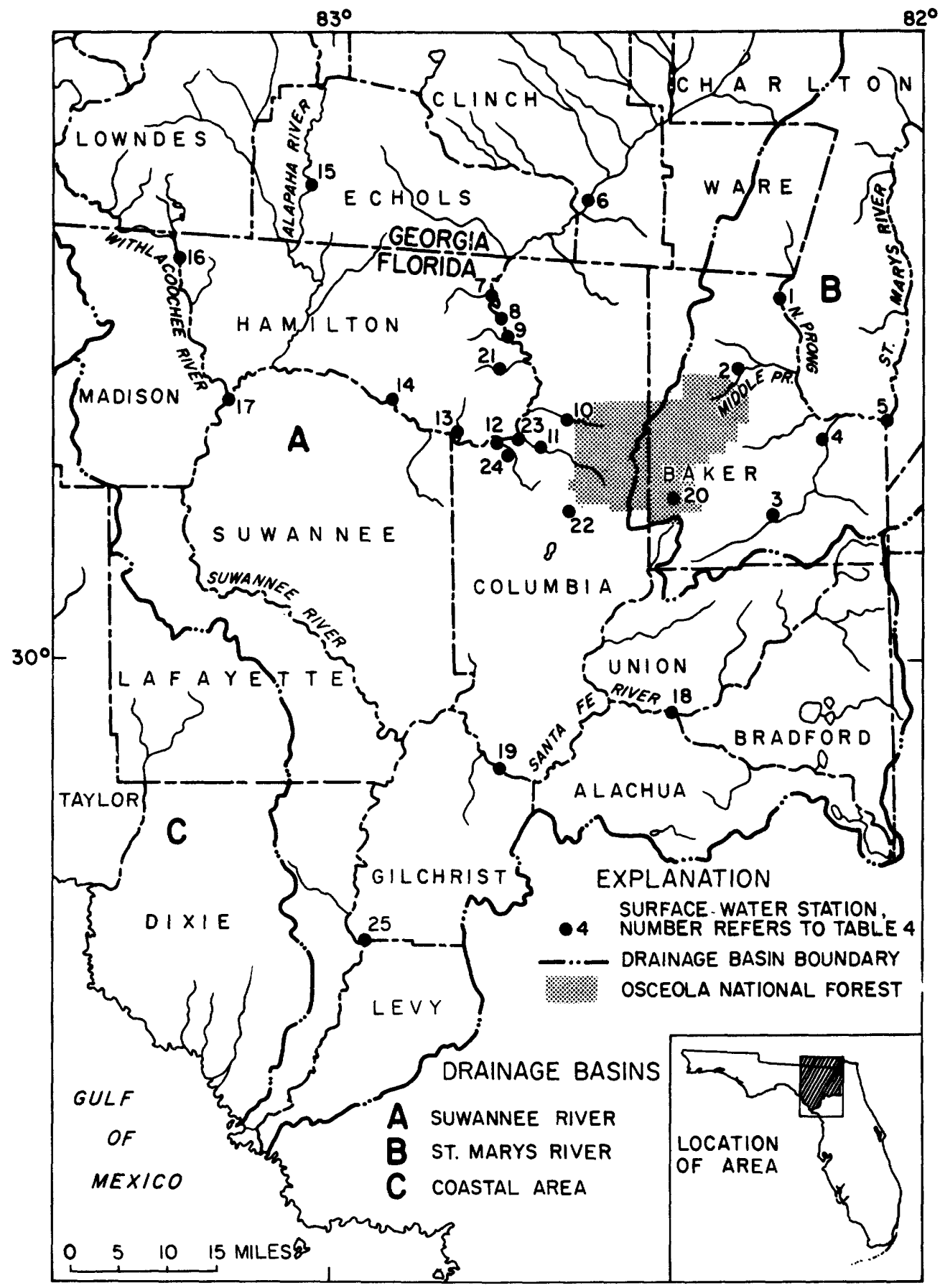

FIGURE 7.--DRAINAGE BASINS IN PART OF NORTH FLORIDA AND SOUTH GEORGIA, AND SURFACE-WATER STATIONS FOR WHICH RECORDS ARE USED FOR THIS STUDY. 
Table 4.--Surface Water Stations Used for this Study

Down-

stream

Station Order

Number Number
Name and Location
Period of Record (Month and Year)
Fre- Drainage quency Area of (square Record miles)
$1022285.00 \quad$ North Prong St. Marys River at Moniac, Ga.

$$
\begin{aligned}
& 01 / 21-12 / 23 \\
& 01 / 27-06 / 30 \\
& 07 / 32-06 / 34 \\
& 10 / 50-03 / 77
\end{aligned}
$$

$2022290.001 /$ Middle Prong St. Marys River at Taylor, Fla.

$09 / 55-09 / 67$

$04 / 76-03 / 77$

$09 / 55-12 / 60$ near Sanderson, Fla.

$4 \quad 022305.00 \quad$ South Prong St. Marys River at Glen St. Mary, Fla.

$5 \quad 022310.00 \quad$ St. Marys River near Macclenny, Fla.

$01 / 50-09 / 71$

$10 / 26-03 / 77$

$01 / 21-09 / 23$

$01 / 27-12 / 31$

$04 / 37-03 / 77$

$7023149.86^{1 /}$ Rocky Creek near Belmont, Fla. 08/70-03/76

$03 / 76-03 / 77$

$8023150.00 \quad$ Suwannee River near Benton, F1a.

$10 / 75-03 / 77$

$9023150.051 /$ Hunter Creek near Belmont, F1a. 05/65-08/71

$10023152.00^{1 /}$ Deep Creek near Suwannee Va1ley, 04/76-03/77 Fla.

$11023153.921 /$ Robinson Creek near Suwannee 03/76-03/77 Va11ey, F1a.

12023155.00 Suwannee River at White Springs,05/06-12/08 Fla.

$02 / 27-03 / 77$
08/69-04/76 04/76-03/77
$\mathrm{P}$
65.3
D

160

$\mathrm{P}$

P

$P$

D

D

125

D

D

57.8

D

156

D $\quad 700$

$\begin{array}{ll}\text { P } & 1,260 \\ \text { P } & \\ \text { D } & \end{array}$

P

50

D

D 2,090

$\begin{array}{ll}\mathrm{P} & 25.4 \\ \mathrm{P} & \end{array}$

D $\quad 88.6$

D $\quad 27.4$

D 2,430

D 
Table 4.--Surface Water Stations Used for this Study (continued).

\begin{tabular}{|c|c|c|c|c|c|}
\hline $\begin{array}{l}\text { Station } \\
\text { Number }\end{array}$ & $\begin{array}{l}\text { Down- } \\
\text { stream } \\
\text { Order } \\
\text { Number }\end{array}$ & Name and Location & $\begin{array}{l}\text { Period of Record } \\
\text { (Month and Year) } \\
\end{array}$ & $\begin{array}{c}\text { Fre- } \\
\text { quency } \\
\text { of } \\
\text { Record } \\
\end{array}$ & $\begin{array}{c}\text { Drainage } \\
\text { Area } \\
\text { (square } \\
\text { miles) } \\
\end{array}$ \\
\hline 14 & 023155.50 & $\begin{array}{l}\text { Suwannee River at Suwannee } \\
\text { Springs, Fla. }\end{array}$ & $\begin{array}{l}11 / 60-09 / 74 \\
10 / 74-03 / 77\end{array}$ & $\begin{array}{l}P \\
D\end{array}$ & 2,630 \\
\hline 15 & 023175.00 & $\begin{array}{l}\text { Alapaha River at Statenville, } \\
\text { Ga. }\end{array}$ & $\begin{array}{l}01 / 21-06 / 21 \\
10 / 31-03 / 77\end{array}$ & $\begin{array}{l}P \\
D\end{array}$ & 1,400 \\
\hline 16 & 023190.00 & $\begin{array}{l}\text { Withlacoochee River near } \\
\text { Pinetta, Fla. }\end{array}$ & $10 / 31-03 / 77$ & D & 2,120 \\
\hline 17 & 023195.00 & $\begin{array}{l}\text { Suwannee River at Ellaville, } \\
\text { Fla. }\end{array}$ & $01 / 27-03 / 77$ & $\mathrm{D}$ & 6,970 \\
\hline 18 & 023215.00 & $\begin{array}{l}\text { Sante Fe River at Worthington } \\
\text { Springs, Fla. }\end{array}$ & $10 / 31-03 / 77$ & $\mathrm{D}$ & 575 \\
\hline 19 & 023225.00 & $\begin{array}{l}\text { Sante Fe River near Fort Whit } \\
\text { F1a. }\end{array}$ & ite, $\begin{array}{l}10 / 27-01 / 30 \\
06 / 32-03 / 77\end{array}$ & $\begin{array}{l}\mathrm{D} \\
\mathrm{D}\end{array}$ & 1,017 \\
\hline 20 & 022870.00 & Ocean Pond at 01ustee, F1a. & $\begin{array}{l}12 / 74-03 / 75 \\
07 / 75-03 / 77\end{array}$ & $\begin{array}{l}\mathrm{D} \\
\mathrm{W}\end{array}$ & 13.1 \\
\hline 21 & 023150.90 & Roaring Creek near Belmont, & F1a. 11/67-08/70 & $P$ & 17.5 \\
\hline 22 & 023154.50 & Watertown Lk, at Watertown, & F1a.08/66-02/67 & $\mathrm{P}$ & \\
\hline 23 & & Be11 Spring & $\underline{2} / 03 / 15 / 77$ & $P$ & \\
\hline 24 & & Fa11ing Creek & $\underline{2} / 03 / 15 / 77$ & $P$ & \\
\hline 25 & 023235.00 & $\begin{array}{l}\text { Suwannee River near Wilcox, } \\
\text { Fla. }\end{array}$ & $\begin{array}{l}10 / 30-09 / 31 \\
10 / 41-03 / 77\end{array}$ & $\begin{array}{l}\mathrm{D} \\
\mathrm{D}\end{array}$ & 9,640 \\
\hline
\end{tabular}

Data continue to be collected (Sept. 1977) at those stations with a March 1977, date, except for Stations 23 and 24.

Frequency of Record: P, periodic; D, daily; W, weekly.

1/ Stations established, re-established, or modified specifically for this project.

2/ Measured once, on date given. 
turns westward at White Springs, Florida (station 12), near the northwest corner of Osceola National Forest, and then winds its way generally southward to the Gulf of Mexico. The St. Marys River flows south past the northeast part of the forest, where it turns to flow first eastward, then north, and finally eastward again to the Atlantic Ocean. About 45 percent of the forest is drained by tributaries to the Suwannee River and about 55 percent by tributaries to the St. Marys River.

The flow of the Suwannee River above White Springs consists mostly of surface drainage from the Okefenokee Swamp and other swampy areas and of ground-water discharge from the surficial aquifer. Base flow of the Suwannee River increases greatly downstream from White Springs, as shown by the low-flow frequency curves (fig. 8) for Suwannee River at White Springs (station 12) and Suwannee River at Ellaville (station 17) gaging stations. Inflow to the Suwannee River between White Springs and Ellaville includes the flow of the Withlacoochee and Alapaha Rivers which drain a sizeable area in south-central Georgia (fig. 7). The drainage areas of these streams upstream from gaging stations on the Withlacoochee River near Pinetta (station 16) and the Alapha River at Statenville, Georgia, (station 15) account for 77 percent of the 4,540$\mathrm{mi}^{2}$ increase in drainage area of the Suwannee River between the White Springs and Ellaville stations. However, an analysis of the flow of the Withlacoochee and Alapaha Rivers indicates that during periods of low flow these rivers account for only about 16 percent of the flow of the Suwannee River at Ellaville. Thus, the relatively high base flow of the Suwannee River at Ellaville is not due to the larger basin size but rather is mostly due to ground water from the Floridan aquifer discharging to the river in substantial amounts between the White Springs and Ellaville gaging stations. The Floridan aquifer crops out in the channel of the Suwannee River throughout the reach between White Springs and Ellaville. The low-flow analysis described by Riggs (1972, p.3) suggests that the break in the slope of the low-flow frequency curve for the Suwannee River at White Springs (beginning at about the 5-year recurrence interval) indicates a ground-water component of the flow at this station persisting after flow from the headwater areas ceases.

The flow of the St. Marys River upstream from the confluence of North and Middle Prongs is also largely derived from generally swampy areas. Between the confluence of North and Middle Prongs and the St. Marys River near Macclenny (station 5), the drainage basin is more typical of upland areas than of swamps. From comparison of the low-flow frequency curves of gaging stations in the St. Marys River basin (fig. 9), the base flow of the St. Marys River near Macclenny appears to be derived mostly from the area downstream from the confluence of North and Middle Prongs. On a unit area basis, the base flow of the St. Marys River at Macclenny is the same order of magnitude as the base flow of the Suwannee River at White Springs. For example, for a 2-year recurrence interval the annual minimum 30-day flow is $0.06 \mathrm{ft}^{3} / \mathrm{s}$ per $\mathrm{mi}^{2}$ for the St. Marys River near Macclenny compared to $0.04 \mathrm{ft}^{3} / \mathrm{s}$ per $\mathrm{mi}^{2}$ for the Suwannee River at White Springs. 


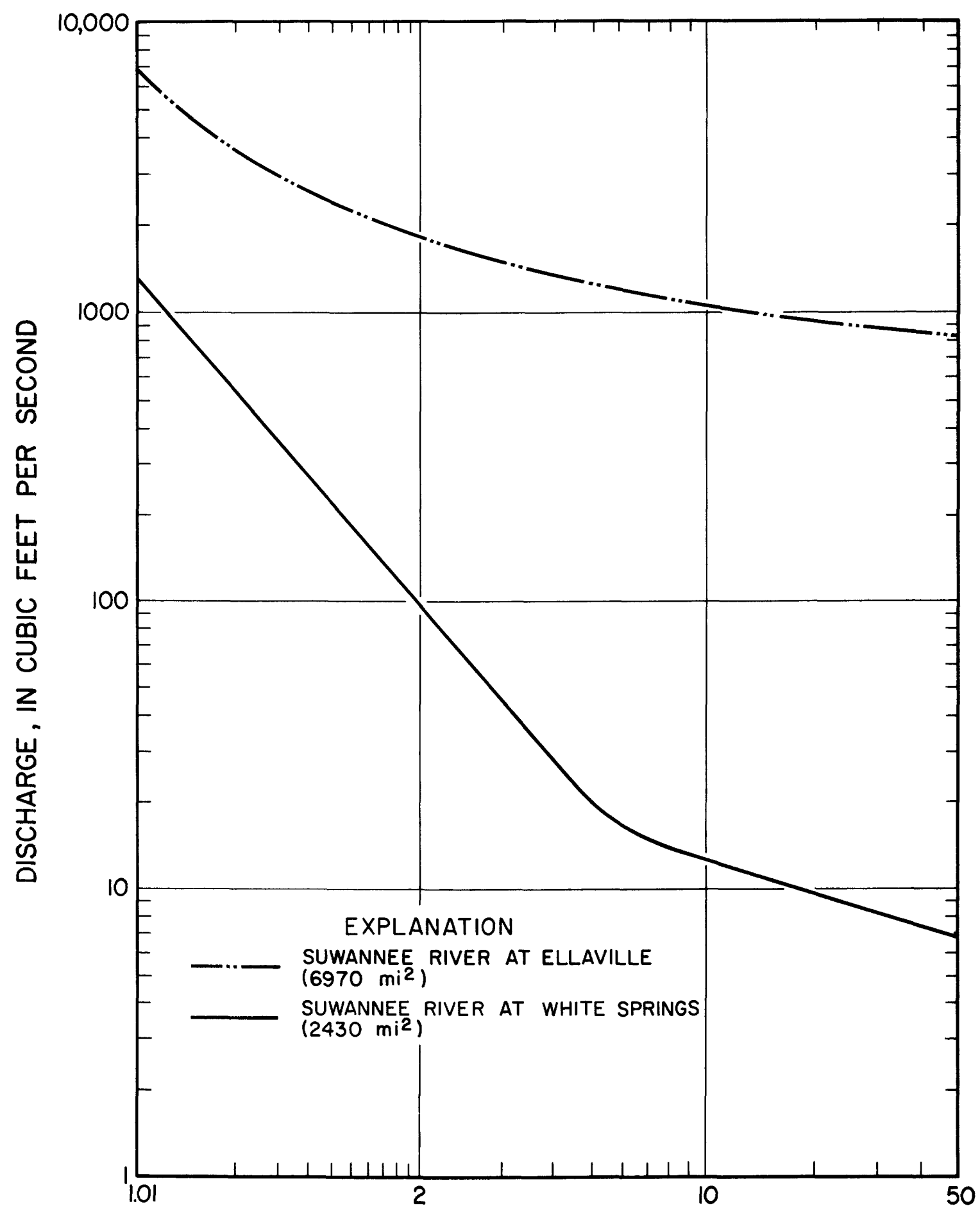

RECURRENCE INTERVAL, IN YEARS

FIGURE 8.--MAGNITUDE AND FREQUENCY OF ANNUAL MINIMUM 30-DAY AVERAGE FLOW AT SELECTED GAGING STATIONS ON SUWANNEE RIVER. (DRAINAGE AREA, IN SQUARE MILES, SHOWN IN PARENTHESES.) 


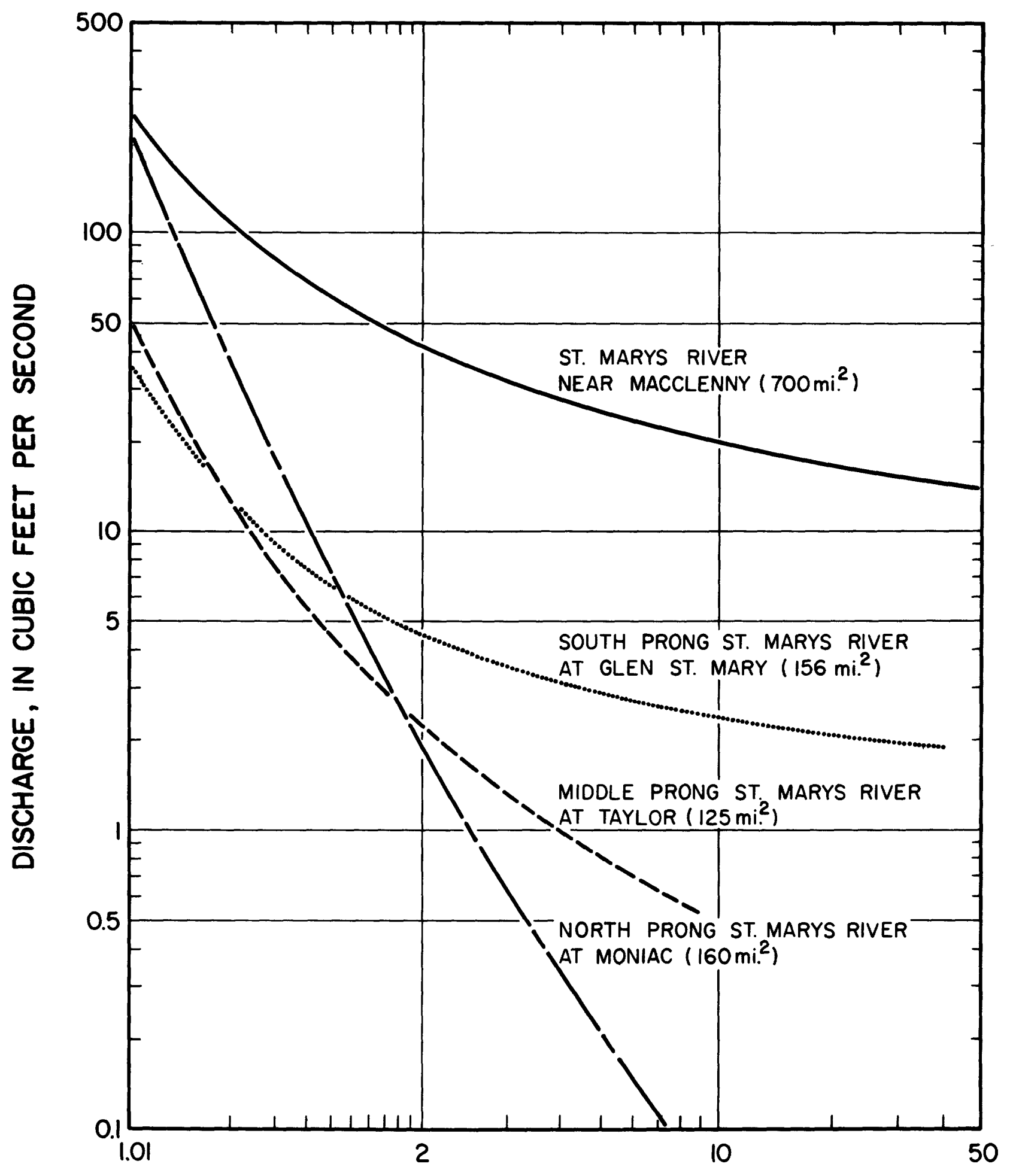

RECURRENCE INTERVAL, IN YEARS

FIGURE 9.--MAGNITUDE AND FREQUENCY OF ANNUAL MINIMUM 30-DAY AVERAGE FLOW AT FOUR GAGING STATIONS IN ST. MARYS RIVER BASIN. (DRAINAGE AREA, IN SQUARE MILES, SHOWN IN PARENTHESES.) 
In total runoff the yields of the upper reaches of the Suwannee and St. Marys River basins also are in the same order of magnitude. Runoff of the Suwannee River at White Springs averages 10.69 inches per year (0.79 $\mathrm{ft}^{3} / \mathrm{s}$ per $\left.\mathrm{mi}^{2}\right)$ compared to 13.37 inches per year $\left(0.98 \mathrm{ft}^{3} / \mathrm{s}\right.$ per $\left.\mathrm{mi}^{2}\right)$ for the St. Marys River near Macclenny.

On a unit area basis the flood peaks of the St. Marys River are substantially greater than those of the Suwannee River. For example, according to Barnes and Golden (1966, p. 36-39) the peak discharge of the mean annual flood is $10.8 \mathrm{ft}^{3} / \mathrm{s}$ per $\mathrm{mi}^{2}$ for the St. Marys River at Macclenny compared to $3.5 \mathrm{ft}^{3} / \mathrm{s}$ per $\mathrm{mi}^{2}$ for the Suwannee River at White Springs. The flood peaks are more attenuated for the Suwannee River than for the St. Marys River owing to the larger basin size of the Suwannee and the greater percentage of swampland there. Although the difference in altitude between the headwaters area and the sea is about the same for both streams, the distance traveled by water is much greater for the Suwannee River than for the St. Marys River, resulting in a lower hydraulic gradient which in turn causes lower streamflow velocities and greater channel storage.

\section{Surface-Water Quality}

The quality of water in surface streams in the four-county area is similar. Exceptions are streams the.t have been affected appreciably by man's activities and those that receive extensive ground-water discharge from the Floridan aquifer, such as the Suwannee River downstream from White Springs, and certain streams tn the Santa Fe River basin. Streamflow quality for most of the streams varies temporally in relation to the ratio of surface runoff, which is largely from areas of swamp and flatwoods, to ground-water discharge which is derived largely from the surficial aquifer. At times of high flow the $\mathrm{pH}$ of most surface waters is as low as 3.5 to 4.0 , and color and suspended sediment are commonly high as a result of the flushing of swamps (Kaufman, 1975; J. E. Dysart, written commun., 1977). At times of low flow, most stream waters have $\mathrm{pH}^{\prime}$ 's near 7 , have less color and suspended sediment, and have somewhat higher concentrations of dissolved solids than at high flows owing to the predominately ground-water source of the streamflow. However, the overall range in dissolved-solids ccncentration is not great because water from the surficial aquifer is not highly mineralized. Dissolvedsolids concentrations (residue) are commonly about $100 \mathrm{mg} / \mathrm{L}$ or 1 ess during both high and low flow. Regardless of stream stage, the water maintains a "mixed" character in that no ion significantly dominates the chemistry of the streamflow.

Ine quality of water of the Suwannee River below White Springs is more variable than that of most of the other streams in the four-county area owing to the proportionately high input from the Floridan aquifer. Water from the Floridan aquifer is more mineralized than that from the surficial aquifer or swamps. During moderate to low flow periods, water in the Suwannee River at Suwannee Springs has a dissolved-solids concen- 
tration (residue) that ranges between 120 to $350 \mathrm{mg} / \mathrm{L}$, depending primarily upon the extent of contribution of Floridan aquifer water to the river. During periods when surface flow is derived mostly from the Floridan aquifer, the $\mathrm{pH}$ of the river water is commonly above 5.0. At times of high flow, when ground-water discharge from the Floridan to the Suwannee River below White Springs is proportionately low or zero, the water quality of the river is similar to that of the other streams in the four-county area. The quality of many tributary streams of the Santa Fe River is similar to that of the Suwannee River between White Springs and Suwannee Springs.

The quality of a few streams in Hamilton County is influenced somewhat by phosphate industry operations. A later section of this report discusses the quality of these streams in detail. In general, concentrations of dissolved solids, suspended sediment, fluoride, sulfate, phosphorous, and nitrogen are higher in streams affected by phosphate operations than in nearby unaffected streams.

\section{Ground Water}

Hydrogeologic Units

The rocks of Tertiary and Quaternary age that underlie Osceola National Forest and adjacent areas can be grouped into three major hydrogeologic units (table 3). In descending order, these units are: surficial aquifer, Hawthorn confining unit, and Floridan aquifer. The pre-Tertiary formations occur at considerable depth in this area (greater than 1,800 ft.) and contain highly mineralized water. These older formations are not relevant to this study and, therefore, they are not discussed further.

The surficial aquifer consists of unconsolidated sand of postMiocene age, locally containing clay and peat beds. Where the uppermost beds of the Hawthorn Formation are permeable and are hydrologically continuous with the overlying post-Miocene deposits, they form the lower part of the surficial aquifer. In this mainly unconsolidated aquifer ground-water storage and movement takes place in intergranular openings. Water in the surficial aquifer is unconfined and in hydrologic continuity with streams and lakes that intersect the water table. Over much of the area the water table is at or within a few feet of land surface throughout the year. Small amounts of water are obtained from the surficial aquifer by shallow domestic wells.

The Hawthorn confining unit underlies the surficial aquifer in much of the region and, where present, separates it hydrologically from the underlying Floridan aquifer. Areally, the confining unit is highly variable in thickness and is composed of clay, sandy clay, limestone, and poorly-to well-consolidated sand. The Hawthorn confining unit retards movement of water between the surficial and Floridan aquifers to varying degrees depending on its thickness and lithologic character at a 
given place. To the south and west of 0sceola National Forest, sinkholes breach the confining unit and facilitate interchange of water between the aquifers. Locally, sandy beds of the confining unit yield small quantities of water under artesian conditions to wells.

The Floridan aquifer constitutes the principal aquifer throughout most of Florida and southeast Georgla (Stringfield, 1966, p. 95). It consists of a thick and areally extensive sequence of interbedded limestones and dolomites of Paleocene to middle Miocene age. Although these carbonate rocks differ vertically and horizontally in texture, porosity, and permeability, they can be treated as a single hydrologic unit in that, overall, their internal hydrologic dissimilarities are minor compared with dissimilarities between them and other units. Ground-water storage and movement in the Floridan takes place through a complex admixture of intergranular openings, cavities, and solution channels. Water in the Floridan occurs under confined, or artesian, conditions over wide areas where it is overlain by Hawthorn beds of much lower permeability. But where the aquifer is at or near land surface or in those places where no confining bed overlies it, such as in the area of the Suwannee River downstream of White Springs, unconfined conditions prevail. The Floridan yields large supplies of ground water to wells; appropriately constructed wells commonly yield a few thousand gallons per minute.

Movement of Ground Water

Recharge to the surficial aquifer is almost entirely from rainfall. Once the infiltrating water reaches the water table of the surficial aquifer, the path it follows depends largely on the thickness and permeability of the Hawthorn confining unit. Where the confining bed is thick and relatively impermeable, virtually all the water entering the surficial aquifer is lost to evapotranspiration or moves laterally towards streams and lakes that intersect the water table and discharges to them. Because of the very low lateral hydraulic gradients that prevail in this area, most of the water movement in the surficial aquifer probably occurs as local flow systems associated with the local surface drainage.

Wherever the head at the base of the surficial aquifer stands higher than the potentiometric surface of the Floridan aquifer, some of the recharge to the surficial aquifer percolates through the Hawthorn confining unit and becomes part of the water moving through the Floridan. Where the Hawthorn confining unit is relatively permeable, thin, breached, or absent altogether, water moves readily from the surficial aquifer to the Floridan and little or no local surface drainage exists. In those places, virtually all of the ground-water movement in the surficial aquifer is downward rather than lateral. Where the potentiometric surface of the Floridan aquifer stands higher than the head at the base of the surficial aquifer, flow is upward from the Floridan to the surficial aquifer. The potentiometric surface of the surficial aquifer, the water 
table, is a slightly subdued replica of the topography. Direction of movement of water, both regionally and locally in the surficial aquifer, is thus controlled in part by the topography.

Patterns of recharge, discharge, and water movement for the Floridan aquifer are considerably more complex than for the surficial aquifer. Water moves into and out of the Floridan aquifer in the four-county area in response to regional gradients indicated by the potentiometric surface on figure 10. Downward leakage from the overlying surficial aquifer inputs additional water to the Floridan within the region wherever the head at the base of the surficial aquifer stands higher than the potentiometric surface of the Floridan. Direct recharge can be provided locally where the Floridan is intersected by sinkholes. Where the aquifer is exposed in stream beds, streamflow infiltrates the aquifer during periods when stream levels stand higher than the aquifer's potentiometric surface. At other stream stages, water discharges from the Floridan to the stream wherever the channel is incised into the aquifer, such as that of the Suwannee River downstream of White Springs. Additional discharge from the Floridan occurs by upward leakage to the surficial aquifer where the head at the base of the surficial aquifer stands lower than the potentiometric surface of the Floridan. Numerous wells also discharge water from the Floridan aquifer within the region.

\section{Fluctuations of Potentiometric Surfaces}

Major fluctuations of the potentiometric surfaces of aquifers occur in response to changes in rates of recharge and discharge, both natural and artificial. Data on water-table fluctuations in the surficial aquifer in the four-county area are sparse, but indicate that the maximum long-term (20 years) fluctuation of the water table is on the order of 5 feet, based on records of a well south of Ocean Pond. Seasonal and long-term fluctuations of the water table in the surficial aquifer generally are greatest in upland areas and least in lowland areas.

The potentiometric surface of the Floridan aquifer has fluctuated as much as 18 feet in the four-county area over the past 28 years, based on records of well 14 in Lake City (fig. 11A) with little apparent longterm trend. Most of the major fluctuations of figure $11 \mathrm{~A}$ are the result of variations in rainfall, as shown by their correlation with a plot of cumulative departure from the average rainfall (fig. 11B). Minor fluctuations are caused by changes in atmospheric pressure and by earth tides where the aquifer is confined. Locally, large fluctuations in the potentiometric surface of the Floridan are related to stream stage where the aquifer is directly connected to a stream.

\section{Ground-Water Quality}

Chemical analyses of water from the surficial aquifer in the fourcounty area show a dissolved solids concentration (sum) of less than 50 $\mathrm{mg} / \mathrm{L}$ and a specific conductance of less than $100 \mu \mathrm{mhos} / \mathrm{cm}$. Major ions 


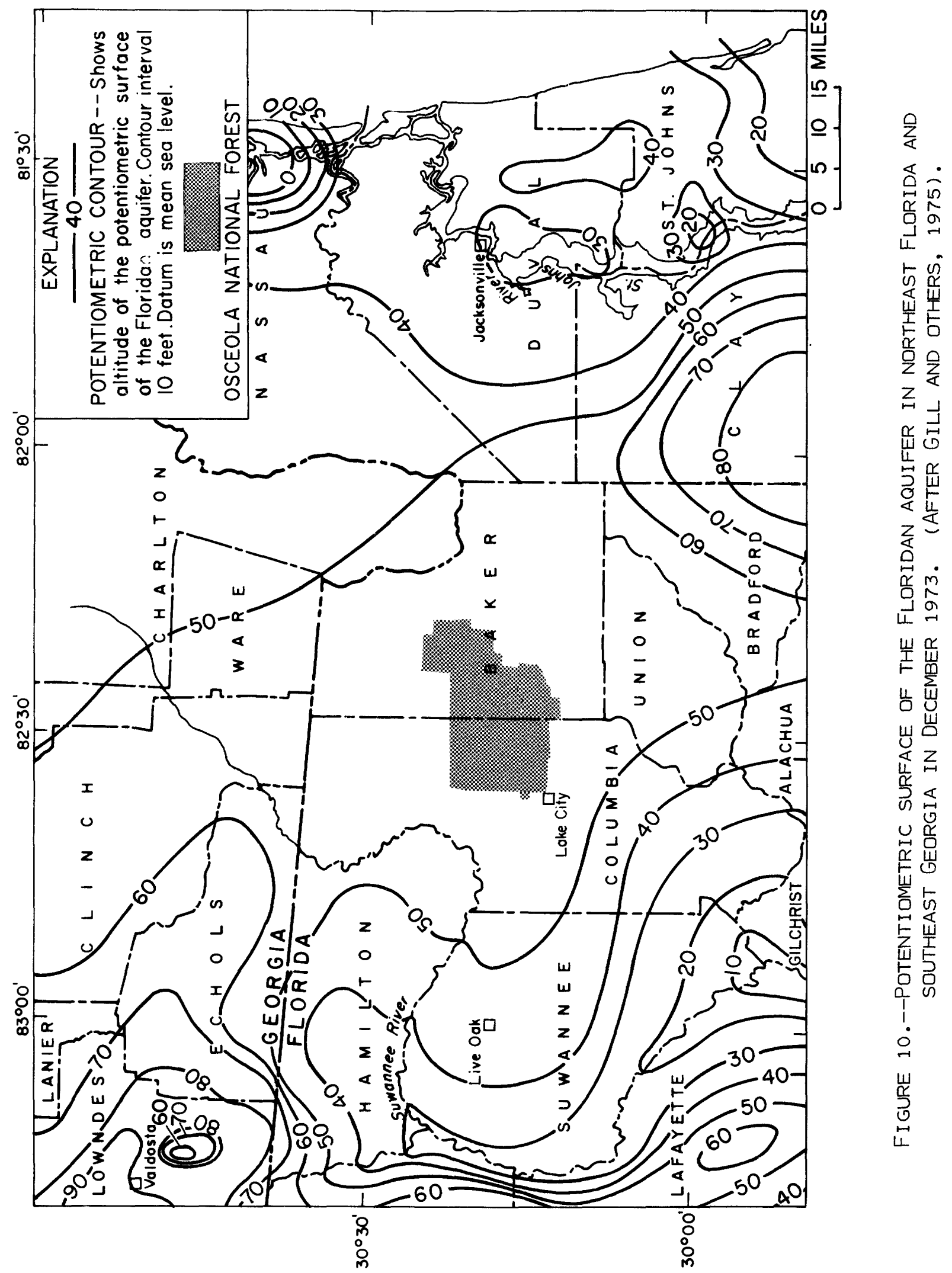




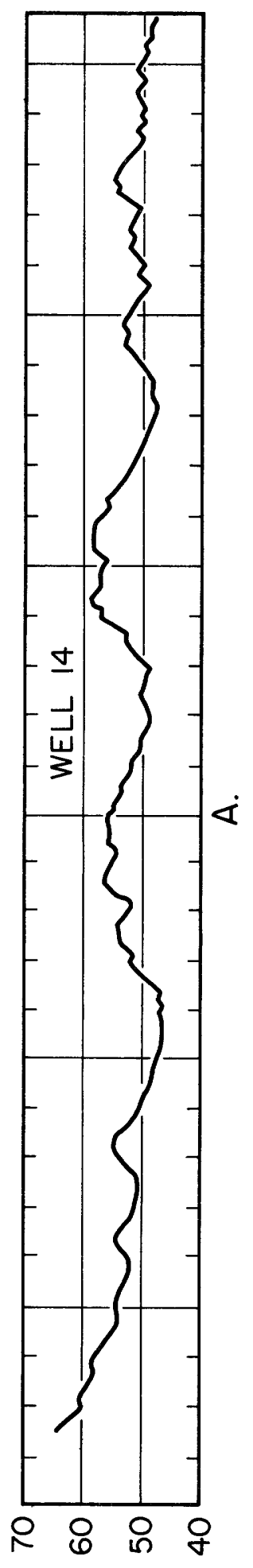

$\neg \exists \wedge \exists า \forall \exists S N \forall \exists W$ $\exists \wedge 08 \forall 1 \exists \exists \unlhd \mathrm{NI}$ ' $\exists \wedge \exists า ~ y \exists \perp \forall M$

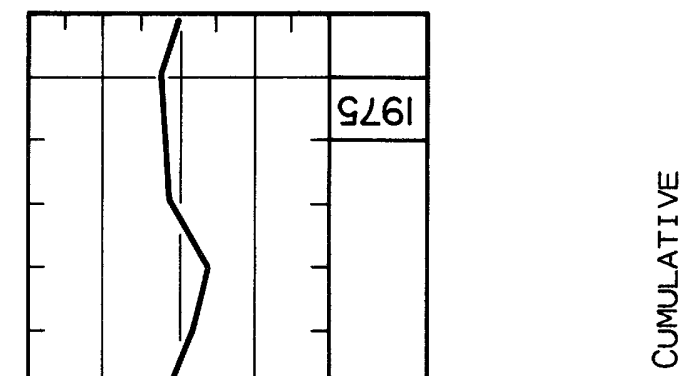

- 0 0<61

$\check{t}$

皆

㟧

过

这

舀它

党

ชั

希卡

언

突

प1

岌

$F$

난

究交

近

$\vdash$ 峲

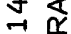

$+\frac{W}{4}$

Ш

岌

岩

项

$\bar{\alpha}$

岁

항

兵这

40

!

$\stackrel{-1}{-}$

崩

SЭHONI NI ‘ ר $\forall \exists$ NIVY 7 $\exists y \cap \perp \forall \forall d \exists 0 \quad \exists \wedge I \perp \forall า \cap W \cap ว$ 
include bicarbonate (less than $10 \mathrm{mg} / \mathrm{L}$ ), chloride (less than $15 \mathrm{mg} / \mathrm{L}$ ), calcium (less than $10 \mathrm{mg} / \mathrm{L}$ ), and sodium (less than $15 \mathrm{mg} / \mathrm{L}$ ). The water has a $\mathrm{pH}$ of less than 7.0. Color exceeds 100 platinum-cobalt units. Where the lower part of the surficial aquifer includes permeable beds of the uppermost part of the Hawthorn Formation, ground water is more mineralized.

Water in the sandy beds near the middle of the Hawthorn confining unit is also more mineralized than that in the upper sandy part of the overlying surficial aquifer. Dissolved solids and bicarbonate concentrations are several times greater than in water from the upper part of the surficial aquifer. Calcium and magnesium are the dominant cations; their concentrations are as much as 100 and $35 \mathrm{mg} / \mathrm{L}$ respectively. Water from the Hawthorn generally has a higher $\mathrm{pH}$ and has less color than that from the surficial aquifer.

The regional chemical character of water from the Floridan aquifer has been portrayed on various maps. These maps show that within the four-county area the upper part of the Floridan contains water with the following concentrations: dissolved solids (sum) less than $500 \mathrm{mg} / \mathrm{L}$ (Shampine, 1975a), bicarbonate less than $300 \mathrm{mg} / \mathrm{L}$, hardness greater than $120 \mathrm{mg} / \mathrm{L}$ (Shampine, 1975b). Sulfate concentrations according to Shampine $(1975 \mathrm{c})$, are less than $50 \mathrm{mg} / \mathrm{L}$.

Deeper parts of the Floridan aquifer contain water that is more mineralized. The lowermost beds of the Floridan contain saline water nearly everywhere in Florida. Thickness of the part containing potable water differs from place to place, but has been estimated to range in the study area from 750 feet in southernmost Suwannee County to 1,750 feet in easternmost Baker County on the basis of chloride and dissolved solids concentrations (Klein, 1975). However, data from wells in Valdosta, Georgia, and Lake City, Florida, suggest that sulfate concentrations high enough to exceed drinking water standards occur at shallower depths than do the saline zones. The available data do not permit delineation of the depth to the base of potable water, based on sulfate concentrations.

Temporally, the quality of water in the Floridan changes 1ittle, except in areas of direct exchange with surface water. For example, spring flow from the Floridan discharges to the Suwannee and Santa Fe Rivers except during periods of high flow when many of these springs backflow and river water recharges the aquifer. In many cases this recharge is effected through cave systems extending many miles ( $\mathrm{J}$. C. Rosenau and others, written commun., 1977). The effects of this recharge by river water have not been investigated to any great extent, but it is logical to assume that the quality of water in the Floridan would be affected wherever and whenever surface water is introduced. 


\section{Hydrogeology}

Prior to this investigation, hydrogeologic data from within Osceola National Forest were meager. Table 5 and figure 12 show the locations, depths, type of completion, and the hydrogeologic unit in which wells $\mathrm{drilled}$ for this investigation and pre-existing wells are completed. To augment available data, ten sites shown on figure 12 were selected for test drilling primarily on the basis of phosphate distribution as shown by the U. S. Forest Service (U. S. Dept. of Interior, 1974, p. XI-5). Most sites are in areas known to be underlain by phosphate with some locations chosen in poorly drained and some in well drained areas. Secondary considerations in site selection were to obtain a good geographic spread over the forest as a whole, and to avoid areas where either drilling or subsequent water-level monitoring would interfere with forest-management practices.

At each drilling site chosen, continuous coring was done through the entire thickness of the Hawthorn Formation. The Eocene beds comprising the Floridan aquifer were cored to a depth of 25 to 30 feet below their top if drilling conditions permitted. Ten core holes were cased and completed as open-hole wells in the Floridan aquifer. A second shallower well was then completed at each site, and was screened either in the surficial aquifer or opposite permeable strata of the Hawthorn confining unit. Digital water-level recorders were installed on both the Floridan wells and the shallow wells and water-level data were collected during a nine- to ten-month period.

All cores taken were described megascopically on site and then processed in a sedimentation laboratory. The lithology and paleontology of the core samples were described in detail after examination with a binocular microscope. The mineralogy, cation exchange capacity, and hydrologic parameters of selected cores from well $2 \mathrm{~V}$ were analyzed by the U. S. Geological Survey Hydrologic Laboratory in Lakewood, Colorado.

Existing commercial electric and induction-electric logs of oil test wells near the boundaries of the forest (fig. 12) were studied to determine the characteristics of pre-Eocene rocks, to outline the broad geologic framework of the area, and to identify the base of the Floridan aquifer. Natural gamma-ray logs were run in each deep test well drilled for this investigation, and single-point electric logs were run in four of these wells (table 5). An inventory of existing wells in and near the forest, conducted early in the investigation, revealed several water wells that penetrated the Floridan aquifer. Natural gamma-ray logs were run in these wells in order to obtain a more complete picture of subsurface conditions in the area.

One of the ten test-drilling sites (site 2, fig. 12) was chosen for detailed aquifer testing to determine the vertical and horizontal hydraulic properties of the Floridan aquifer and the Hawthorn confining unit. 


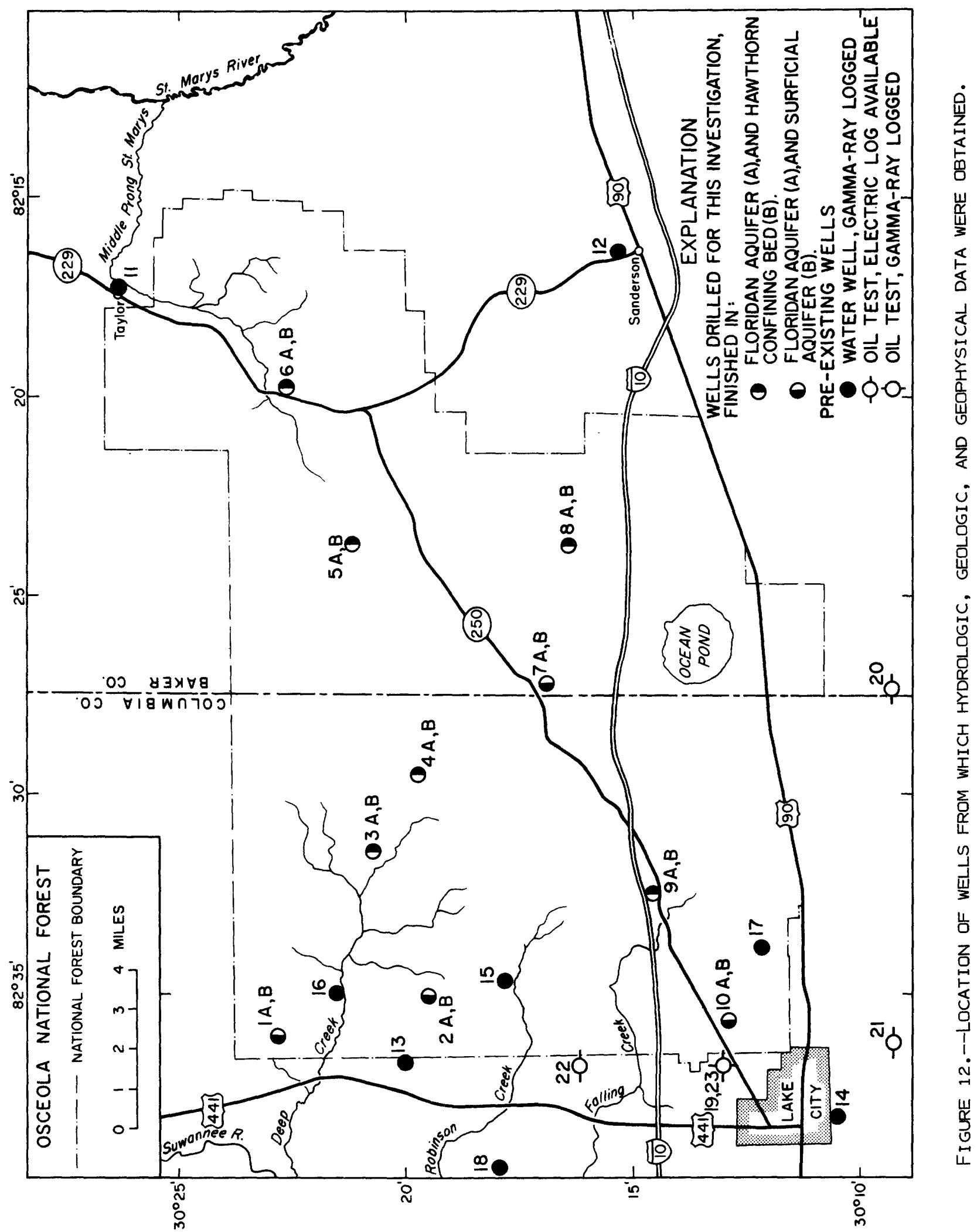




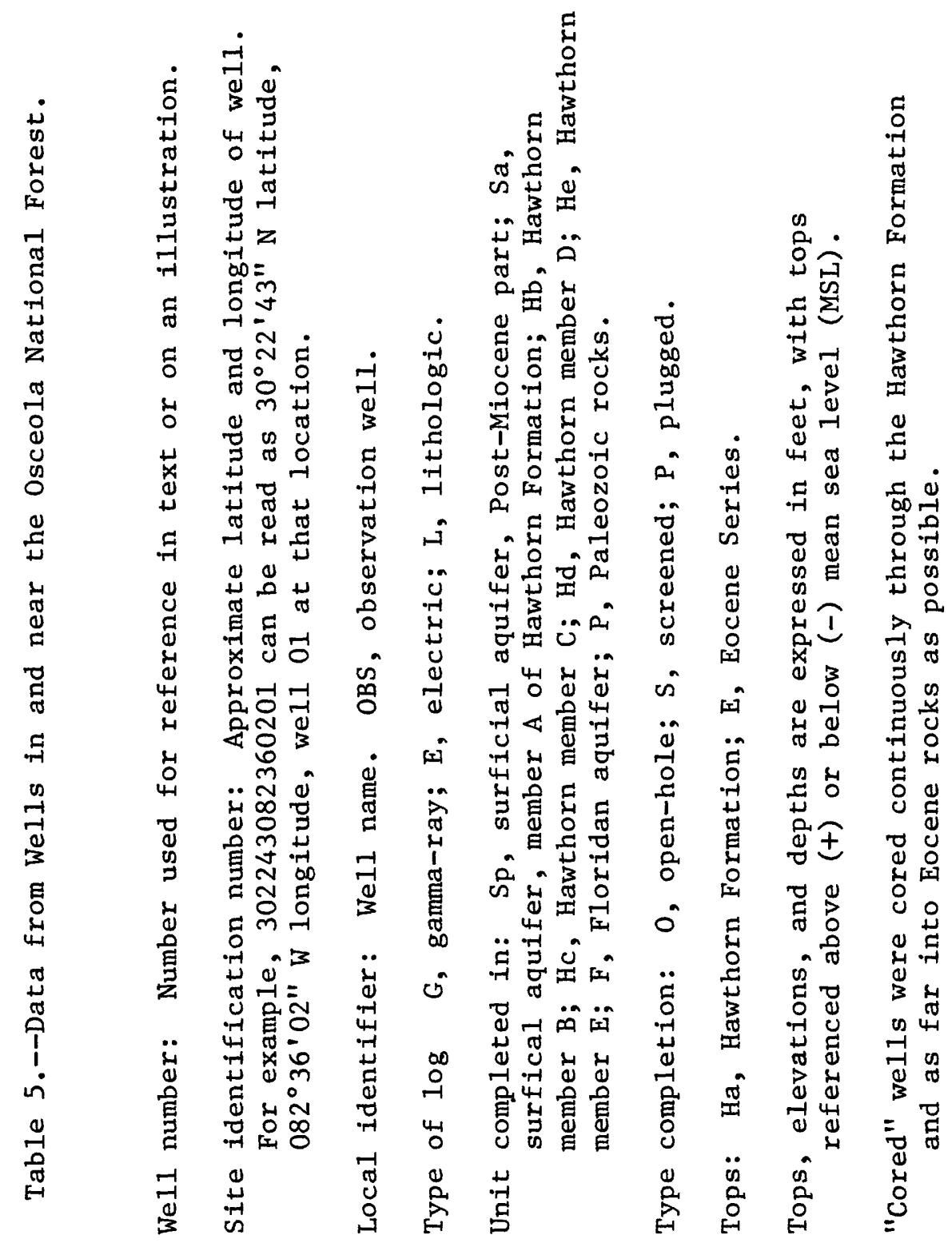




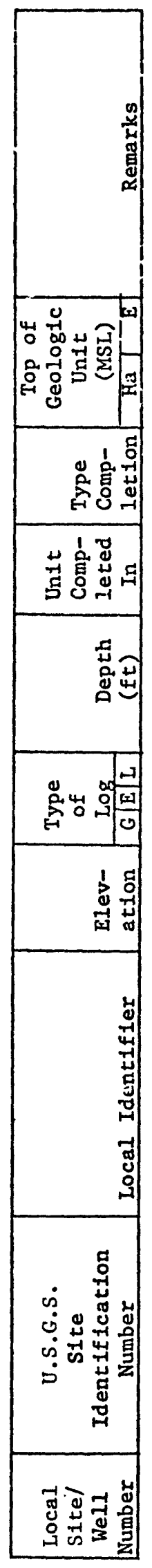

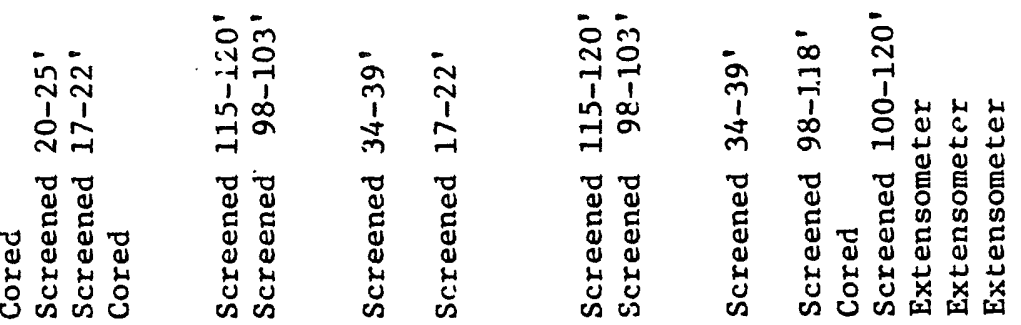

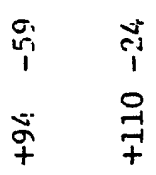

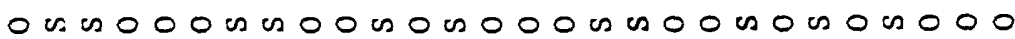

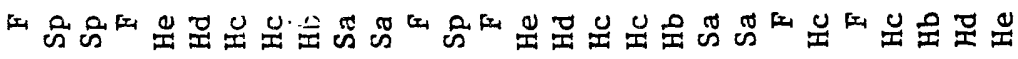

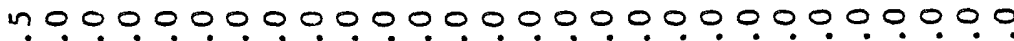

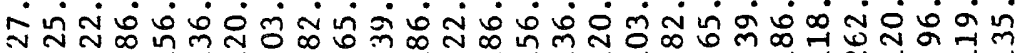

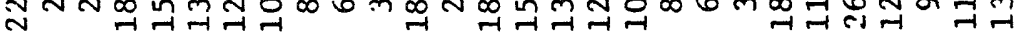

$x \quad x \quad x$

$x \times x \times x \times x \times x \times x \times x \times x \times x x$

옹ํํำ

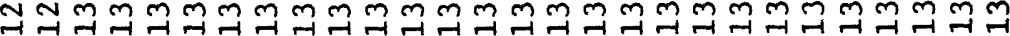

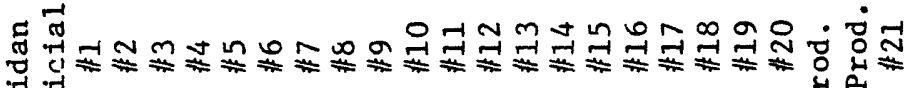

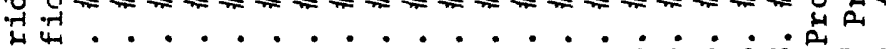

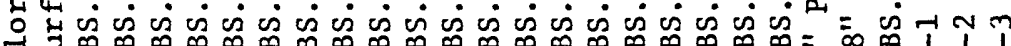

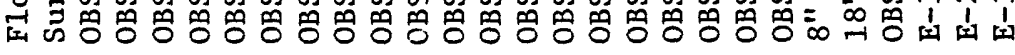

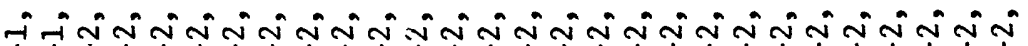

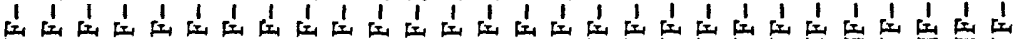

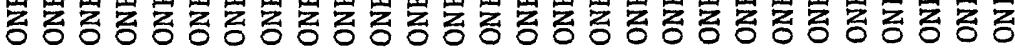

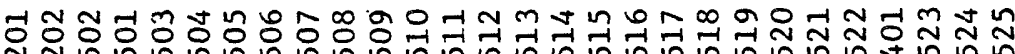

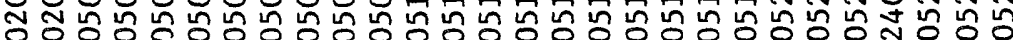

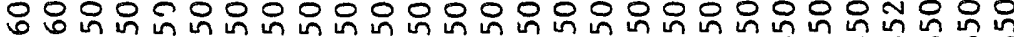
ฟิ

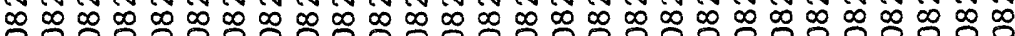
m m m m m m m m m m m m m m

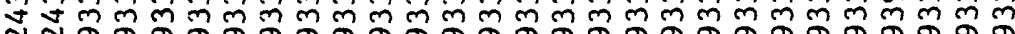

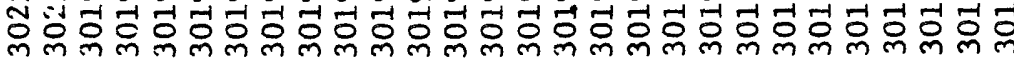

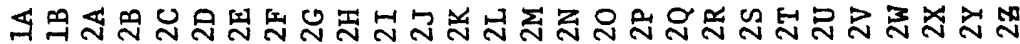




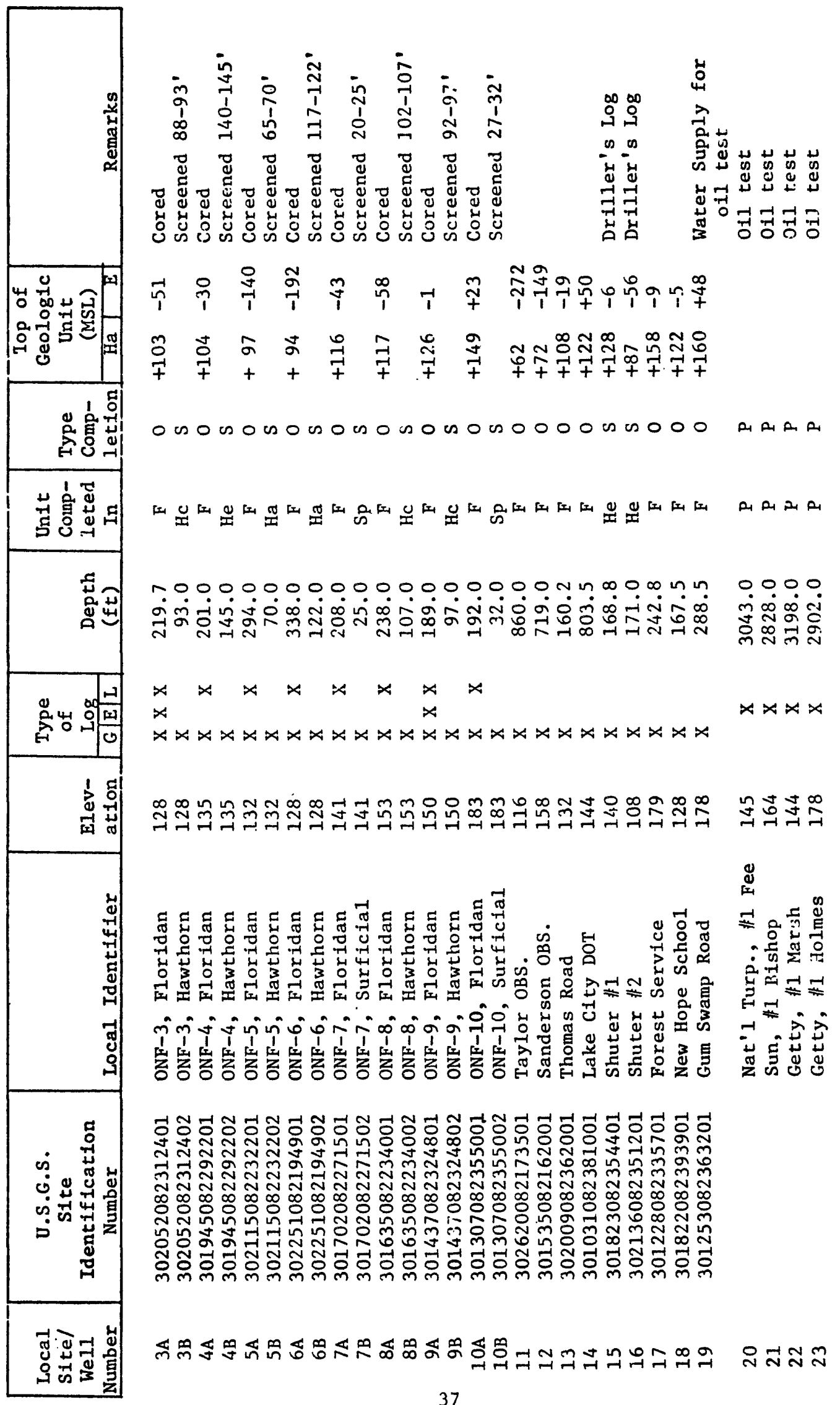


Twenty-one observation wells for water-level measurements, two production wells, and three test holes for extensometer measurements were installed and instrumented at this site as described in the section of this report concerning aquifer testing. Rainfall, air temperature, relative humidity, and barometric pressure were recorded at this aquifertest site, in addition to water levels, from September 28, 1976, through May 20, 1977.

\section{Surface Water}

Table 4 lists surface-water stations from which data were used in this study. Locations of these stations are shown on figure 7 . Six of the twenty-four stations were established, re-established, or modified specifically for this study. The other stations were used for comparison or to facilitate extrapolation of data.

\section{Water Quality}

Chemical analyses were made on surface-water samples collected on a regular monthly basis at the six stations identified by footnote in table 4. Additional samples were collected and analyzed on a hydrologic event (floods, low flow) basis. Laboratory determinations were made of major constituents, selected trace metals, radiochemical parameters, nutrients, organic carbon, and suspended solids. Standard field measurements of $\mathrm{pH}$, dissolved oxygen, specific conductance, and temperature were made at time of sample collection.

Water samples were collected from all satisfactorily producing test wells. Samples were collected also from wells in the present mining area in Hamilton County. Water samples from wells in the forest were analyzed for the same constituents as the surface-water stations, except for dissolved oxygen and suspended sediment. Water samples from wells in the present mining area were analyzed only for $\mathrm{pH}$, temperature, specific conductance, and major constituents.

Samples were collected and analyzed in accordance with the methods described in Brown and others (1970). Filtering of samples for dissolved constituents was carried out with a 0.45 micron filter.

\section{GEOLOGY AND HYDROLOGY OF OSCEOLA NATIONAL FOREST}

\section{Hydrologic System of the Forest}

The physical framework of the hydrologic system in Osceola National Forest conforms to that described earlier for the four-county area: the surficial aquifer is separated from the underlying Floridan aquifer by relatively impermeable beds of the Hawthorn confining unit. 
The lateral boundaries of the surficial aquifer in the forest area are the St. Marys River to the east; an elongate east-west trending ridge which serves as a ground-water divide to the south; the Suwannee River to the west; and swampy areas which comprise the southern limits of the Okefenokee Swamp to the north. Vertically, the boundaries are land surface and the top of the Hawthorn confining unit.

The lateral boundaries of the Floridan aquifer in the forest area are the Santa Fe River and the karst area in Bradford, Union, and Alachua Counties to the south, and Falling Creek and the Suwannee River to the west. The remaining lateral boundaries and the vertical boundaries of the Floridan aquifer are those described earlier for the four-county area.

The forest is drained by several small streams having similar discharge and drainage-basin characteristics. The quality of water in these streams is strongly influenced by ground-water discharge from the surficial aquifer at times of low flow; input from swampy areas is the dominant influence during times of high runoff.

Virtually all of the precipitation on the forest can be accounted for by losses to evapotranspiration and by surface runoff. A small amount of the precipitation leaks from the surficial aquifer downward through the Hawthorn confining unit to the Floridan aquifer in response to the prevailing vertical gradients. The Floridan is also recharged by surface waters through spring or sinkhole connections.

The detailed geologic and hydrologic framework of the Osceola National Forest is described and analyzed in the following sections of this report.

\section{Geology}

General

The flat to gently rolling topography developed on the sand and clay deposits that underlie Osceola National Forest are not conducive to good outcrop development. Thus, most of the geologic interpretations herein are based on subsurface information. The ten core holes (fig. 12) drilled in the forest for this investigation completely penetrated postEocene rocks and a maximum of 102 feet of upper Eocene strata. A11 information concerning middle Eocene and older rocks is based on examination of data from oil-test wells located near the periphery of the forest. Table 3 summarizes geologic units that occur in the area of study, as recognized by the U. S. Geological Survey.

Beds assigned to the Suwannee Limestone of oligocene age have previously been identified in outcrop and subcrop in parts of Columbia and Baker Counties (Meyer, 1962, p. 18). No strata of this age were encountered during the test drilling done for this investigation. 0ligocene rocks are here interpreted as filling paleotopographic lows 
which were depressions eroded into the top of Eocene strata. Isolated pockets of 01igocene rocks possibly exist under Osceola National Forest but, if present, their areal extent and hydrogeologic significance would be smal1.

A brown limestone and calcareous sandstone unit here assigned to the base of the Hawthorn Formation has been previously considered to represent a discrete but unnamed pre-Hawthorn Miocene unit (Meyer, 1962, p. 63). These strata contain a microfauna of middle Miocene age and are no more or no less distinctive as a lithologic entity than the other four subdivisions of the Hawthorn described below.

\section{Stratigraphy}

\section{Eocene Series}

General.--Eocene rocks in the area of study are comprised, in ascending order, of the Oldsmar Limestone (Sabinian Stage), Lake City and Avon Park Limestones (Claibornian Stage), and the Ocala Limestone (Jacksonian Stage). The Ocala is considered a group by the Florida Bureau of Geology and has been divided into three formations by Puri (1953, 1957); the Inglis, Williston, and Crystal River (table 3). Puri's Crystal River Formation coincides in general with the term "Upper Ocala" of U. S. Geological Survey usage. Of the above units, only the upper part of the Ocala Limestone was penetrated by wells drilled for this investigation and thus only Ocala and younger rocks are described below in detail.

Ocala Limestone.--The top of the Ocala Limestone in the Osceola National Forest area is an unconformable surface that ranges in altitude from 50 feet at well 14 at Lake City to minus 272 feet at we11 11 near Taylor (fig. 13). Chen (1965, p. 19), shows that in north central Florida, the top of the Ocala slopes gently northeastward from the axis of the Ocala up1ift. In Osceola National Forest, Ocala sediments range in thickness from 260 to 380 feet, as interpreted from nearby oil testwell data.

The upper part of the Ocala Limestone is a soft white argillaceous calcarenite with much intergranular porosity. The bulk of the rock consists of foraminiferal remains and medium- to coarse-grained sandsized particles of white limestone which are cemented by a white micritic limestone matrix. Both the matrix and enclosed fossils are commonly recrystallized. Bright green clay frequently occurs as interbeds or large clasts in the upper few feet of this white limestone. The calcarenite is underlain by a gray, fine-grained, hard crystalline limestone which contains echinoid and pelecypod remains. The gray limestone is usually fractured, and this fracturing plus the development of solution cavities as much as three feet high (encountered in well 5A) create difficult drilling conditions. Fluid circulation is commonly lost during drilling because of the large openings in the rock, and either cuttings or core from this interval are difficult to obtain. 


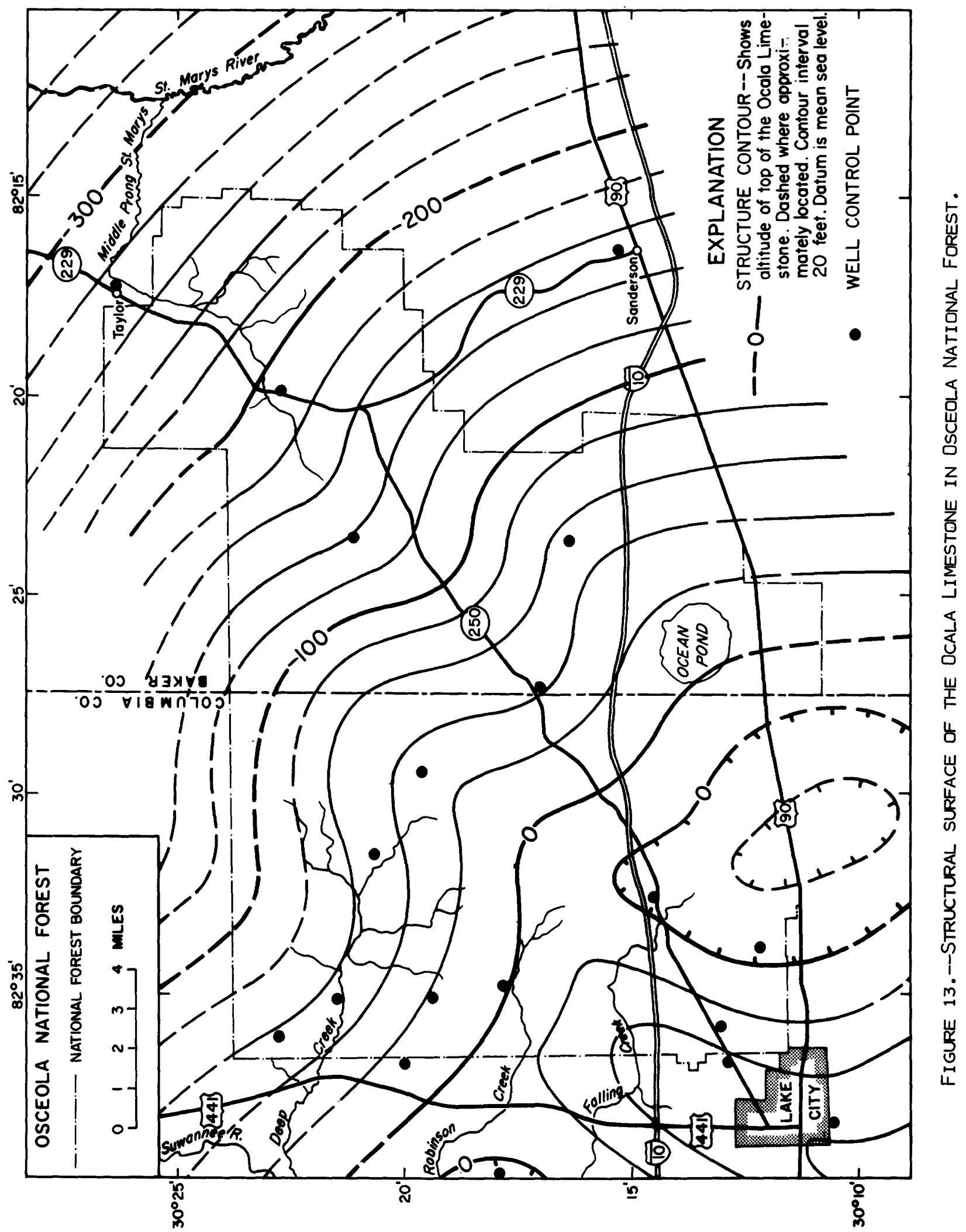


The Ocala Iimestone carries an excellent microfauna of late Eocene age (Jacksonian Stage). The faunal content and lithologic character of these strata throughout Osceola National Forest show they were deposited on a shallow marine shelf. The texture of the original limestone material, prior to recrystallization, is representative of a rock deposited in a high energy environment.

\section{Miocene Series}

Hawthorn Formation.--The Hawthorn Formation, unconformably overlies the Ocala Limestone, and is the only Miocene unit in the forest. The Hawthorn Formation is a sequence of stratified clay, sand, sandy clay, and limestone beds that contains phosphate throughout. The beds are dull green, blue-green, or brown. The highest concentrations of phosphate are found in the uppermost beds of the formation. Microfauna indicate a middle Miocene age for the Hawthorn Formation in Osceola National Forest. The top of the formation slopes gently to the southwest, east and northeast from a closed high near Lake City (fig. 14). This high and a reentrant near the center of the northern margin of the Forest are the result of post-depositional uplift and erosion. The top of the unit ranges from a high altitude of 160 feet near Lake City to a low altitude of 62 feet near Taylor.

The minimum thickness of Hawthorn strata measured was 72 feet at Lake City (fig. 15). The maximum measured thickness was 334 feet near Taylor, in Baker County.

The formation as a whole is marine to the northeast, becomes marginal marine near the center of the forest, and is, in part, deltaic along the western boundary of the forest and in the Lake City area. The grain size of both the sand and phosphatic material in the unit increases in areas representing shallower-water depositional conditions where deeper-water materials such as the diatomaceous clay found at sites $5 \mathrm{~A}$ and $6 \mathrm{~A}$ (fig. 12) are absent.

The Hawthorn Formation is divisible into five distinct lithologic units which are readily identifiable throughout the forest, and which have been assigned informal designation as lettered members. All these lithologic units thicken to the north and east, and are discussed below in the order in which they were deposited.

Member E: This basal Hawthorn unit consists of calcareous sandstone, sandy limestone, and microcrystalline argillaceous limestone, all of which are generally tan to dark-brown and well indurated. Minor lightgray medium- to coarse-grained sand occurs in thin beds and stringers throughout the unit. The carbonate rock types are dolomitized to some extent. Dark-gray to brown fine- to coarse-grained sand-sized phosphate grains are scattered throughout the unit. Vuggy porosity is well developed in the limestone and sandy limestone beds due to selective 


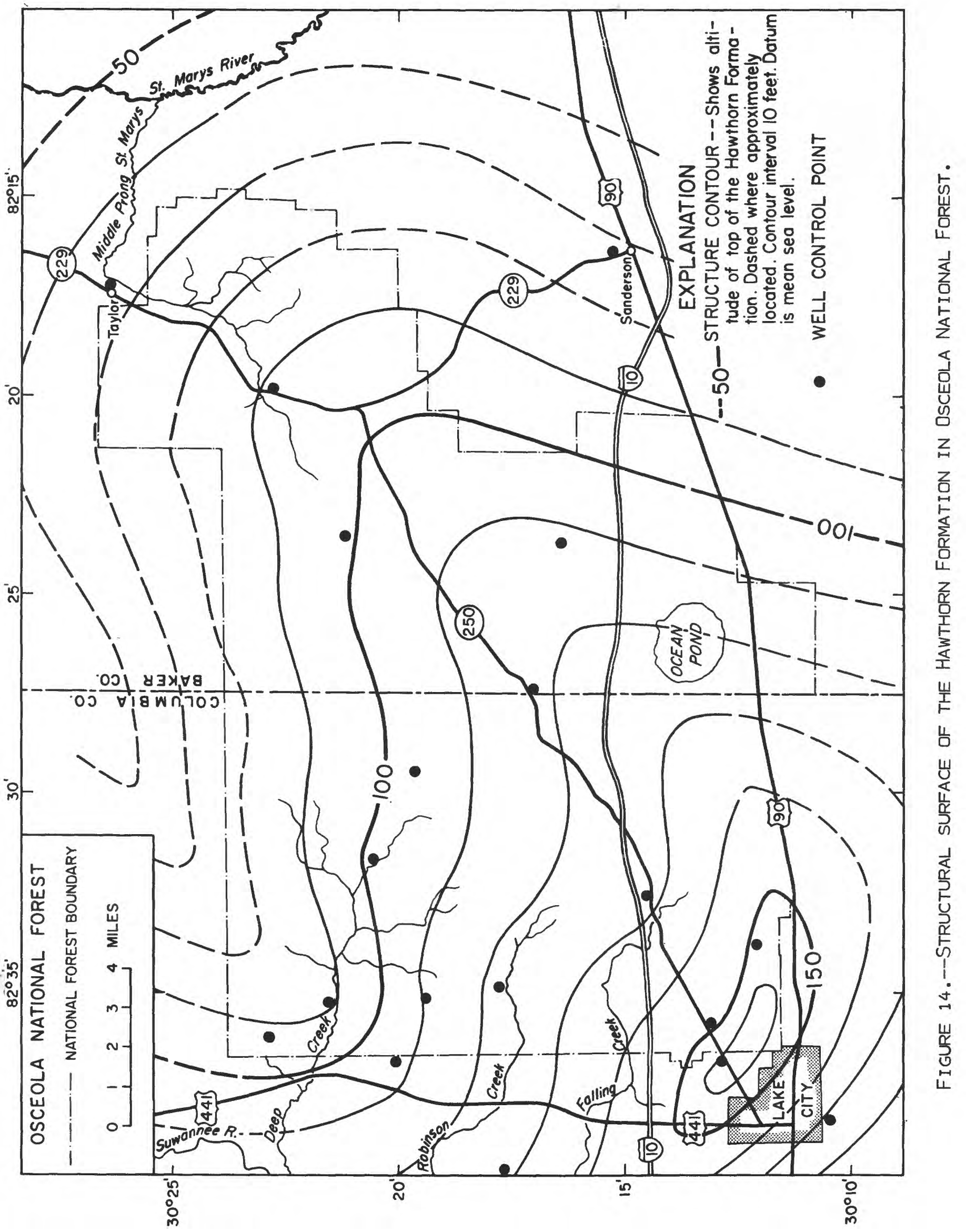




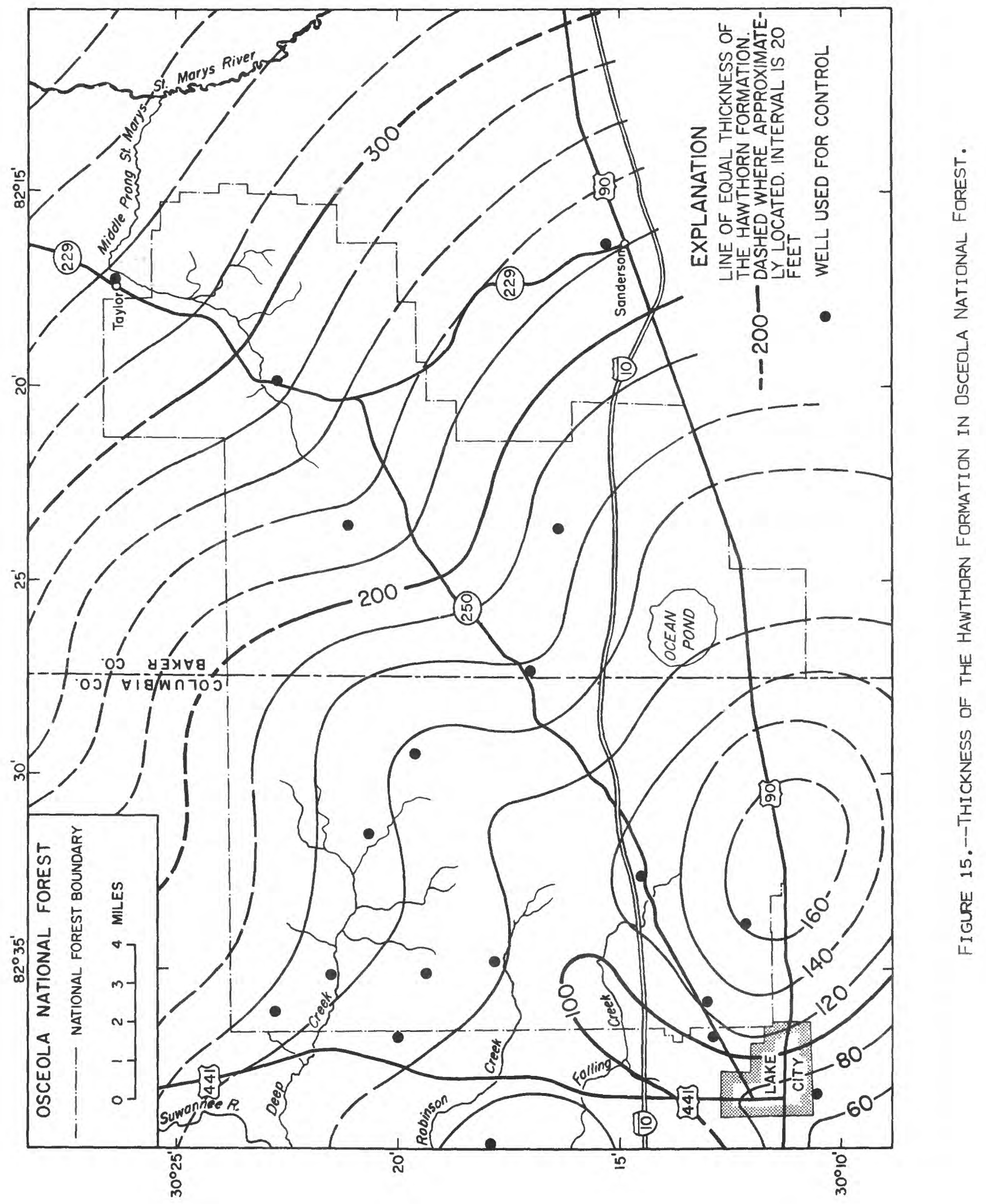


solution of Pecten and other pelecypod shell material but vugs are usually not connected. In addition to this vuggy porosity, some intergranular porosity is present in the sandier portions of member $E$. Extensive recrystallization has filled much of the original pore space in rocks of member $\mathrm{E}$ with fine crystalline calcite.

Several species of Foraminifera and Ostracoda diagnostic of a middle Miocene age have been recovered from member $E$. Shark teeth and manatee ribs occur in the unit at well 10A. Small vugs filled with asphaltic material are common near the middle of the unit at well $6 \mathrm{~A}$.

The thickness of member $E$ varies from a minimum of 14 feet at well $7 \mathrm{~A}$ to a maximum of 73 feet at well 11, and averages about 35 feet in the forest. The top of the unit is at a maximum of 70 feet altitude at well 14 at Lake City, and slopes northeastward to minus 199 feet altitude at we11 11 near Taylor.

Member D: This complexly interbedded unit is the most 1ithologically variable of the five Hawthorn units delineated. No single rock type is either dominant or characteristic. Member D consists of fine- to mediumgrained calcareous sandstone, fine- to medium-grained sand, and coarsecrystalline sandy limestone, all thin to medium-bedded. Green clay galls, thin beds of olive clay, and stringers of dark-brown phosphatic sand occur sparingly in this unit in the eastern third of the forest. Al1 rock types belonging to this unit are semi-indurated to well-indurated, and most of them carry trace amounts of sand-sized white, tan, grey, or black phosphate. The unit commonly contains oyster fragments, pelecypod casts and molds, and echinoid spines. Sponge spicules and diatoms are prominent near the top of the unit at well $6 \mathrm{~A}$.

The top of member D slopes northeastward from a maximum altitude of 90 feet at wel1 19 near Lake City to a low of minus 168 feet at we11 11 near Taylor. The unit varies in thickness from a minimum of 5 feet at well 13 to a maximum of 43 feet at well 12. The thickness of member D averages 27 feet.

No microfauna are present in this unit except for the diatoms mentioned above. These organisms and the pelecypod and echinoid remains which occur in member $D$ show that these rocks were deposited in a shallow marine environment. Selective solution of pelecypod remains has produced minor vuggy porosity in member $D$, but most of the porosity in the unit is of the intergranular type.

Member C: This unit is the most areally uniform of the five Hawthorn subdivisions, in terms of both thickness and lithology. The strata of member $\mathrm{C}$ are everywhere predominantly well-sorted, fine- to mediumgrained sand containing minor beds and intercalations of indurated to semi-indurated calcareous sandstone; all are greenish-gray. Clay is present as thin beds (well 10A) and as matrix (up to 10 percent) binding the sand grains. Minor amounts of white to tan, sand-sized phosphate 
grains occur throughout the unit. Oysters, microgastropods, Bryozoa, sponge spicules, diatoms, and pelecypod casts and molds occur in member $C$, but none of these organisms has been identified as to species. All of the porosity in the unit is intergranular, and has been reduced slightly by the recrystallization of the original calcite cement.

The top of member C slopes moderately steeply to the northeast from a high altitude of 104 feet at well 19 near Lake City to a low altitude of minus 110 feet at well 11 near Taylor. The unit's surface is irregular as a result of submarine erosion prior to the deposition of the succeeding Hawthorn unit (member B). Member C is 20 to 30 feet thick at most places in the forest.

Member B: This unit is a massive dark-green blocky clay in the western half of the forest. From well 4A eastward (fig. 12), it contains considerable blue-gray to white limestone that makes up as much as half of the unit (we11 8A.) The calcareous strata occur near the top of the unit and increase in thickness and amount to the east. The clays of member B contain little sand. They show fracturing in the upper part of the unit (well 2V), with the fractures either slickensided or filled with black manganese. Member B contains trace amounts of very fine- to fine-grained dark-brown to black phosphate. Pelecypod casts and molds, microgastropods, and Bryozoa are present in this unit, but have not been identified as to species.

The top of member B slopes gently northeastward from a high of 122 feet altitude at well 19 near Lake City, to a low of minus 40 feet altitude at well 11 near Taylor. Slight irregularities on this steady slope are the result of differential compaction. Areas where the unit contains more sand are compacted less than areas where it is composed of nearly all clay. Member $B$ is 20 to 30 feet thick over the southwestern two-thirds of the forest, and thickens gradually northeastward to a maximum of 70 feet at well 11 near Taylor.

Member A: This uppermost Hawthorn unit is phosphatic throughout, in places highly so. This is the unit of interest to mining concerns and is the part of the Hawthorn Formation currently being mined for phosphate in Hamilton County. A gray to cream phosphatic shell 1imestone found at or near the base of the unit in most places is the lowermost bed of interest to the phosphate industry, because of the economic unfeasibility of digging indurated material with a dragline.

Member A is highly variable lithologically, consisting of thin- to medium-bedded phosphatic sand, limestone, clay, and sandy clay. The unit is characterized in the western half of the forest by cream to gray soft phosphatic limestone in the lower part, overlain by phosphatic sand and clayey sand. Eastward near the Columbia-Baker County line, member A is comprised of calcareous phosphatic sand, gray to brown clayey sand, and brown phosphatic sand. Farther eastward, brown phosphatic sand, olive clay, and thin beds of dolomite characterize the unit. Member A 
was deposited in a deltaic environment near the western and southern boundaries of the forest, which accounts for the rapid lateral changes in thickness and 1ithology there. Most of the porosity of member Unit A is intergranular.

The structural surface of the Hawthorn Formation (surface of member A) shows gentle relief produced by post-Hawthorn erosion (fig. 14). The thickness of the unit ranges from 15 feet at well 14 to 102 feet at well 11 and is highly variable in the western two-thirds of the forest. Oyster fragments occur sparsely in the unit, and shallow-water Foraminifera of middle Miocene age were recovered from it at well 7A. These microfossils, along with those recovered from member $E$, show that the entire Hawthorn Formation in the Osceola National Forest is of middle Miocene age.

The type of phosphate in member A varies considerably. Black to brown, wel1-sorted, medium sand-sized phosphate is found in the eastern half of the forest, representing primary deposits formed in a fully marine environment. Farther west, increasing amounts of fine to very coarse pebble-sized phosphate particles occur, commonly found with fish bones and teeth. The latter deposits, of the land-pebble type, represent material reworked from older Hawthorn strata which once cropped out to the south and west of the study area but are now stripped away.

\section{Pleistocene-Holocene Series}

A11 rocks younger than middle Miocene in Osceola National Forest are non-marine in orgin and therefore cannot be dated more exactly than post-Miocene. Pliocene strata, as far as can be determined from the 1iterature, are represented in north Florida by part of the Alachua Formation, a lithologic entity which is absent in the forest. The illdefined terracing developed on post-Miocene strata in the area of investigation was probably developed during Pleistocene time. There is no clearcut lithologic basis for differentiation of this terraced material from floodplain and other materials that are probably Holocene. Rocks of both ages are accordingly treated here as one unit.

Post-Miocene rocks in the forest are comprised mostly of fine- to medium-grained unconsolidated to poorly consolidated sand. Tan to dark brown and blue-gray clay occurs in amounts up to 30 percent, mostly as a binder between sand grains, but in places as discrete beds. The clay content of the post-Miocene rocks is, in general, greater toward the eastern side of the forest, but scattered lenses of clay occur also near the western boundary (we11 2B). Much lignite and peaty organic material are present in these sands and clays, and occur as disseminated particles and rarely as woody layers near the top of the unit. These rocks have intergranular porosity. 
Except for a thin soil cover which has been developed on the postMiocene material, the structural surface of these strata is coincident with land surface. These sediments were apparently deposited as a fairly uniform blanket of sand on the existing Hawthorn surface and were subsequently terraced by marine erosion.

\section{Surface Water}

\section{Drainage Basins}

Surface drainage patterns are not sharply defined in much of Osceola National Forest. Stream channels are shallow except in the lowermost part of the basins where the streams empty into the larger rivers. Water tends to pond in low areas that interconnect during wet periods when the surficial materials are saturated to the land surface. Shallow drainage ditches along the roadways collect much of the surface flow. Swamps cover about 30 percent of the forest. Ocean Pond and Watertown Lake in the southern part of the forest are the only natural lakes of any appreciable size (fig. 16). Ocean Pond covers about 1,750 acres ( $2.73 \mathrm{mi}^{2}$ ) but is not in a lease application area. Watertown Lake straddles the southern boundary of the forest about one mile east of Lake City and covers about 46 acres $\left(0.07 \mathrm{mi}^{2}\right)$. The part of Watertown Lake that is in the forest is within a lease application area.

Streams draining the western part of Osceola National Forest are Deep, Robinson, and Falling Creeks, which together drain about 43 percent of the forest (fig. 16, table 6). Deep Creek and Robinson Creek empty directly into the Suwannee River; Falling Creek flows into a sinkhole about 4 miles west of Osceola National Forest. Whether the captured flow of Falling Creek emerges farther downstream in Falling Creek basin or moves underground to the Suwannee River is not known. Streams flowing eastward to the St. Marys River are Middle Prong St. Marys River, South Prong St. Marys River (fig. 2), Cedar Creek, and Bluff Creek, which together drain about 55 percent of the forest. Near the southern boundary of the forest one small area is drained by olustee Creek, which empties into the Santa Fe River and eventually to the Suwannee River and another small area is drained by South Prong St. Marys River. The areas drained by Olustee Creek, Cedar Creek, Bluff Creek, and South Prong St. Marys River are not in the phosphate lease application areas, except for a small part of Cedar Creek basin.

\section{Streamflow Characteristics}

Runoff from Osceola National Forest varies greatly in response to variations in rainfall. The best available index of the long-term variations in runoff from a fairly large segment of the forest is the record of flow of Middle Prong St. Marys River collected at Taylor by the U. S. Geological Survey from September 1955 to October 1967. 


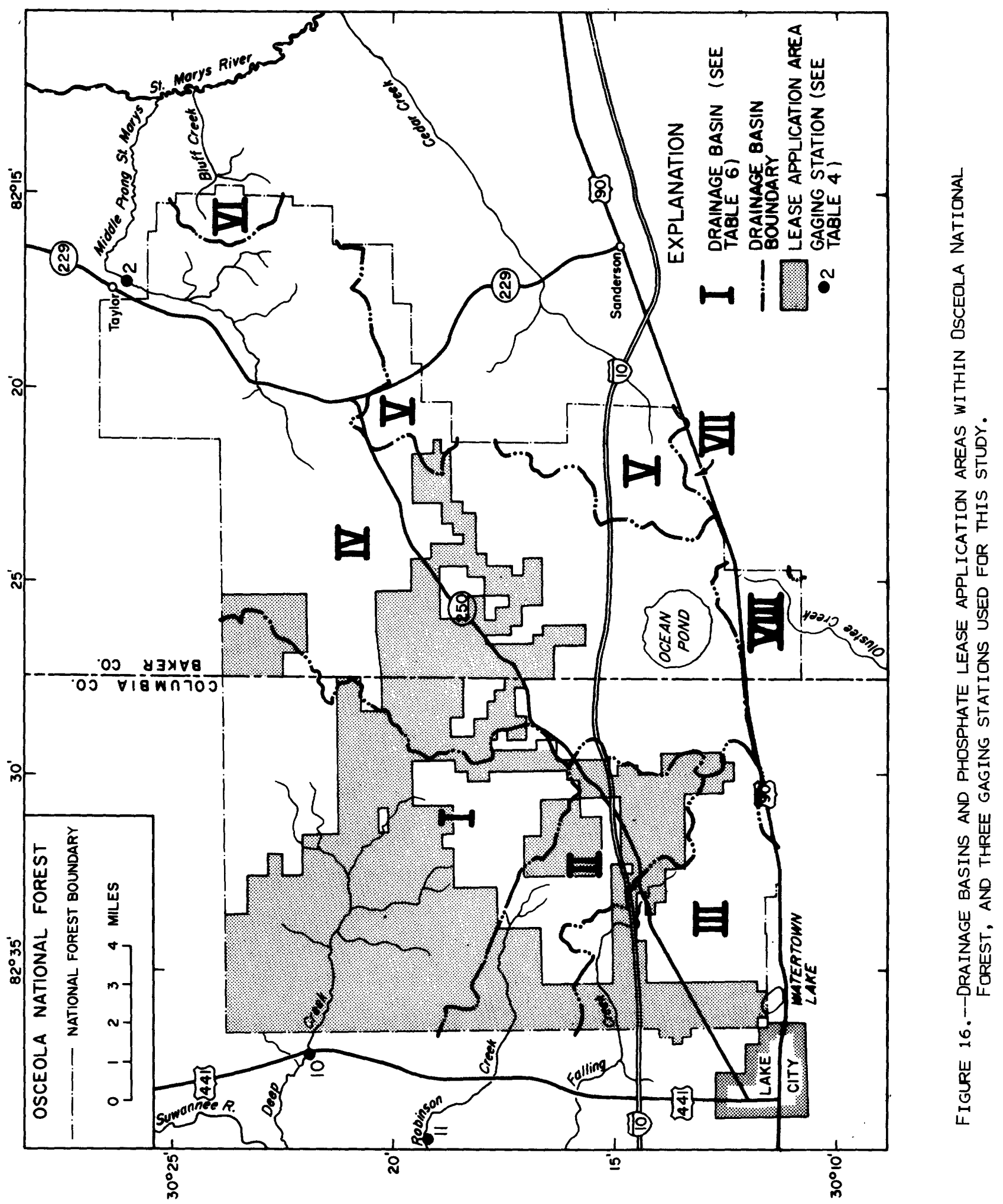


Table 6.--Drainage Basins within Osceola National Forest

Map

Number

Drainage Basin

Acres

Square Percent of

Miles total forest

SUWANNEE RIVER BASIN

43.1

I

Deep Creek

41,990

65.61

25.4

II

Robinson Creek

13,325

20.82

8.1

III

Falling Creek

15,795

24.68

9.6

ST. MARYS RIVER BASIN

IV

V

VI

VII

VIII

Middle Prong St. Marys River

Cedar Creek

Bluff Creek

South Prong St. Marys River

SANTA FE RIVER BASIN

TOTAL

$$
\text { Olustee Creek }
$$

$$
\begin{array}{r}
77,427 \\
10,579 \\
1,818 \\
550
\end{array}
$$$$
120.98
$$$$
16.53
$$$$
2.84
$$$$
.86
$$$$
54.8
$$$$
47.0
$$

6.4

1.1

.3

2.1

$\begin{array}{rrr}3,430 & 5.36 & 2.1 \\ 164,914 & 257.68 & 100.0\end{array}$

NOTE: Drainage areas determined from U. S. Geological Survey topographic maps. U. S. National Forest Service gives acreage within forest boundary as 161,814 acres, of which 157,230 are in public ownership. 


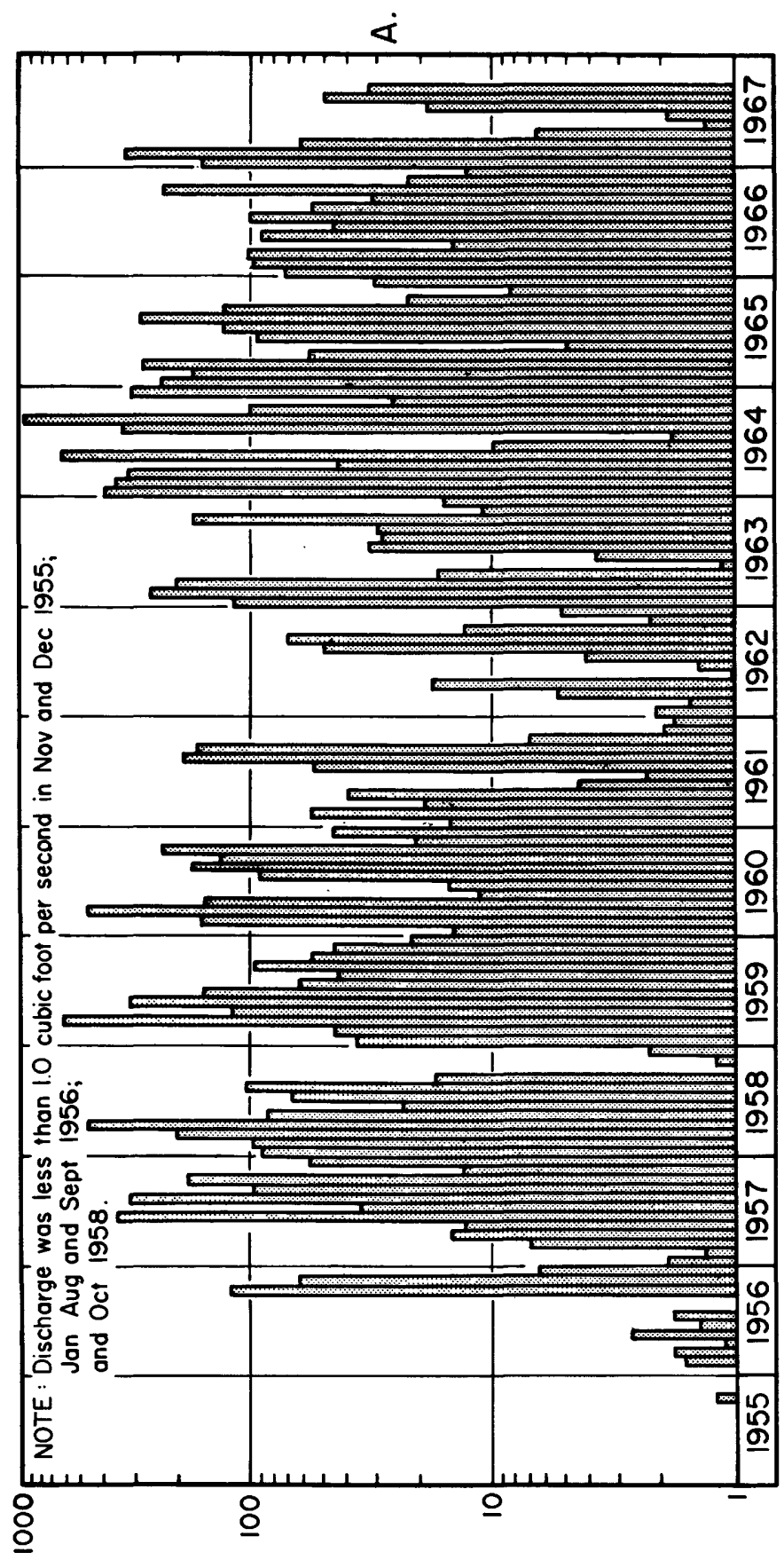

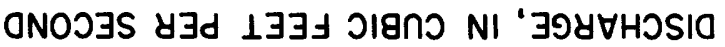

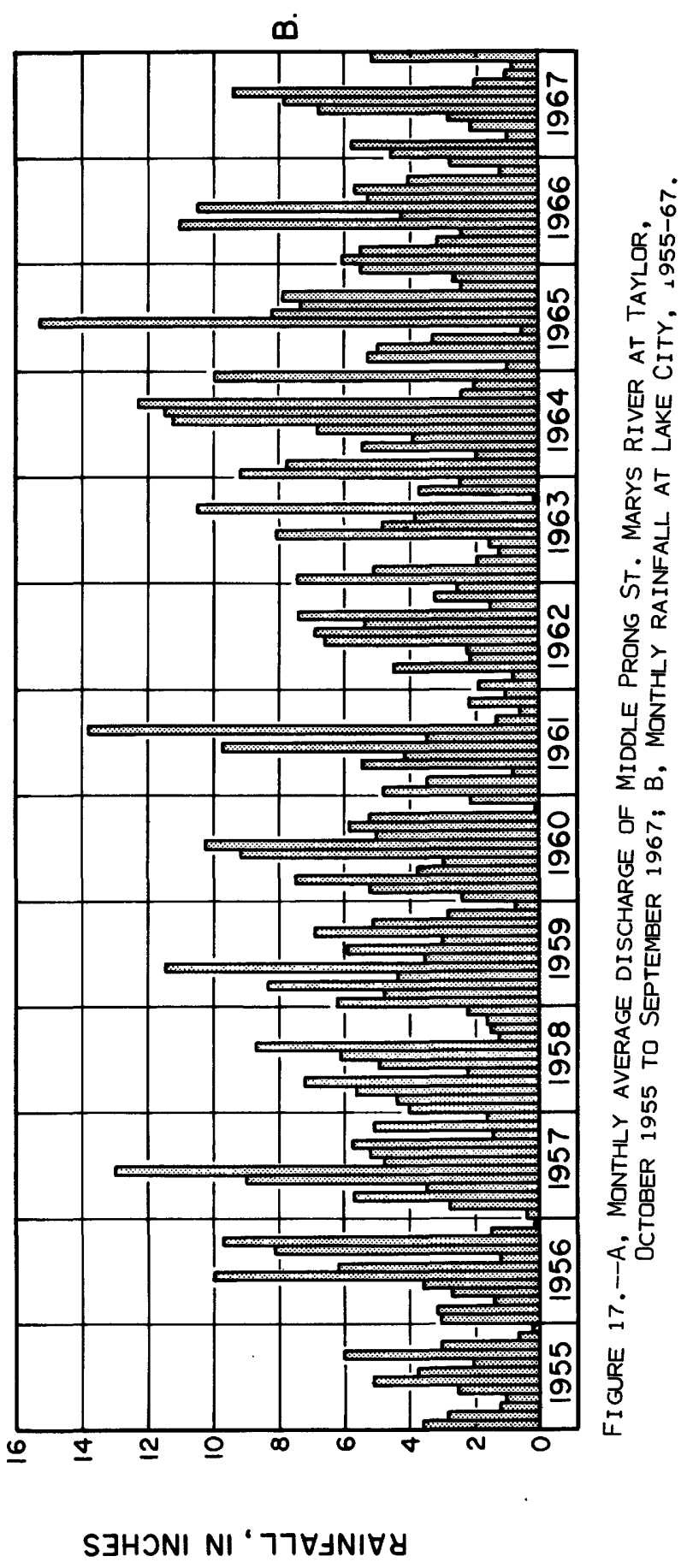




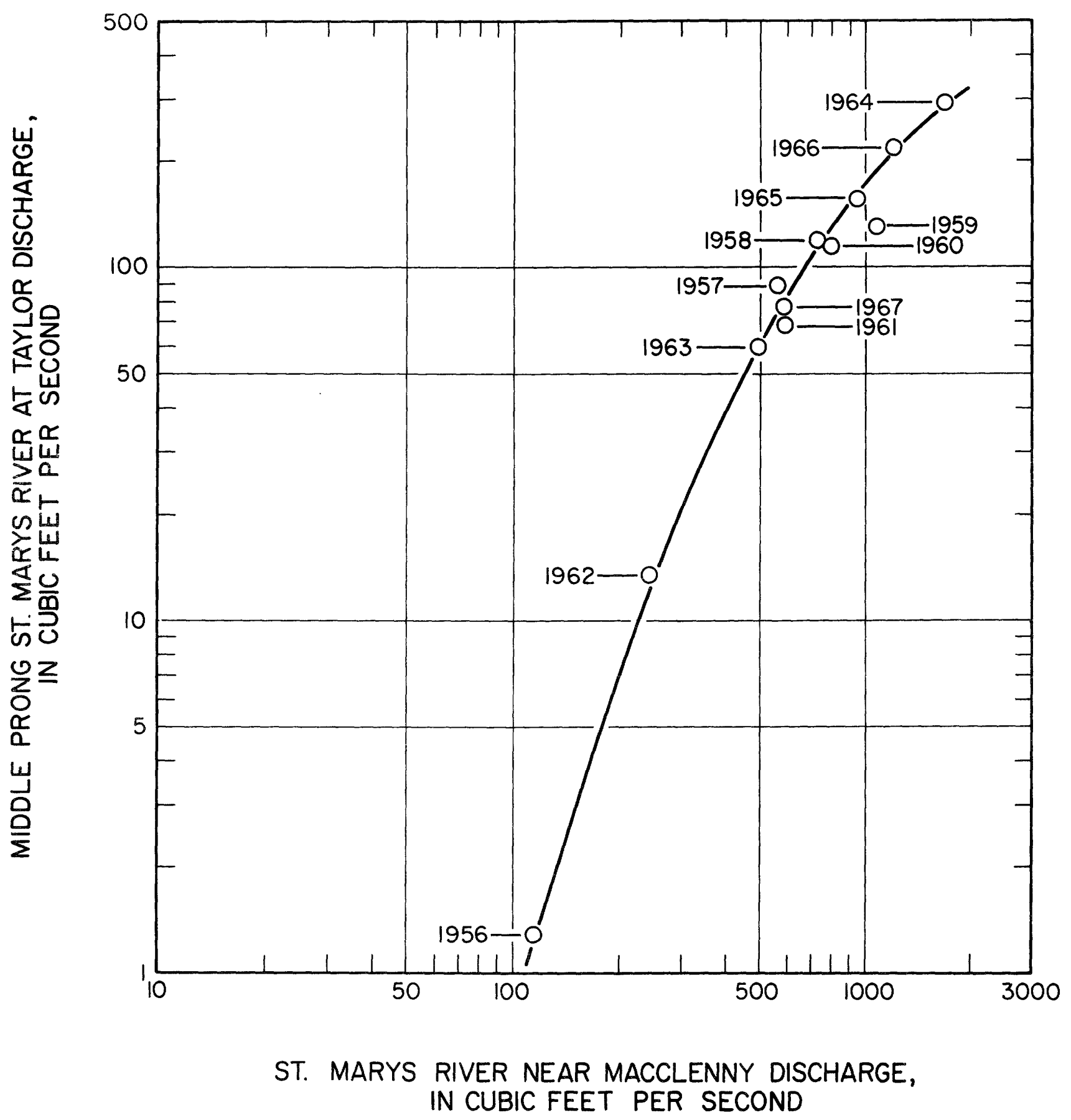

FIgURE 18.--RELATION BETWEEN ANNUAL AVERAGE DISCHARGES OF MIDDLE PRONG St. MARYS RIVER AT TAYLOR AND ST. MARYS RIVER NEAR MACClENNY, 1956-67 WATER YEARS. 


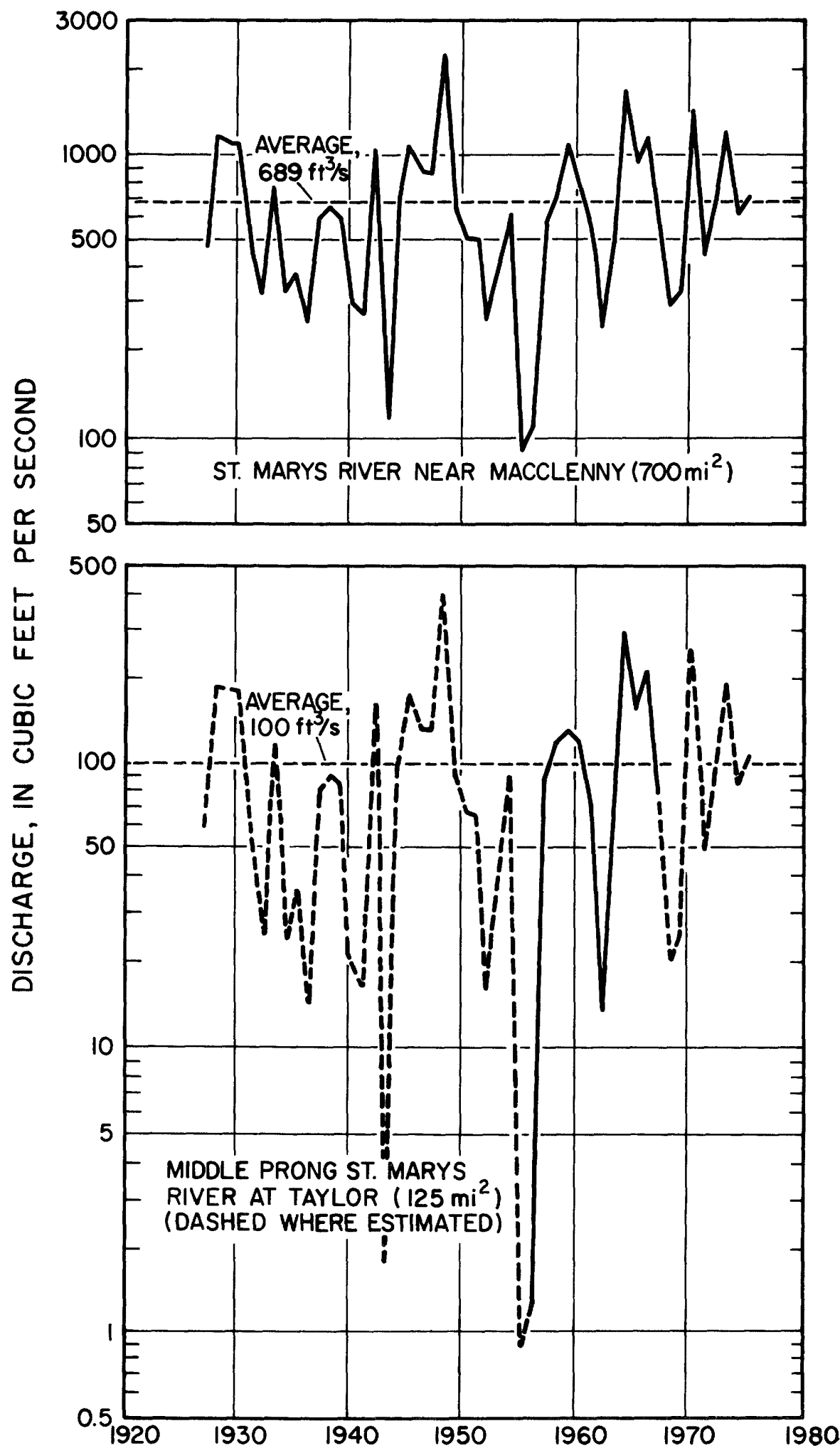

FIGURE 19.--YEARLY AVERAGE DISCHARGE AT TWO GAGING STATIONS IN ST. MARYS RIVER BASIN. (DRAINAGE AREA, IN SQUARE MILES, SHOWN IN PARENTHESES). 

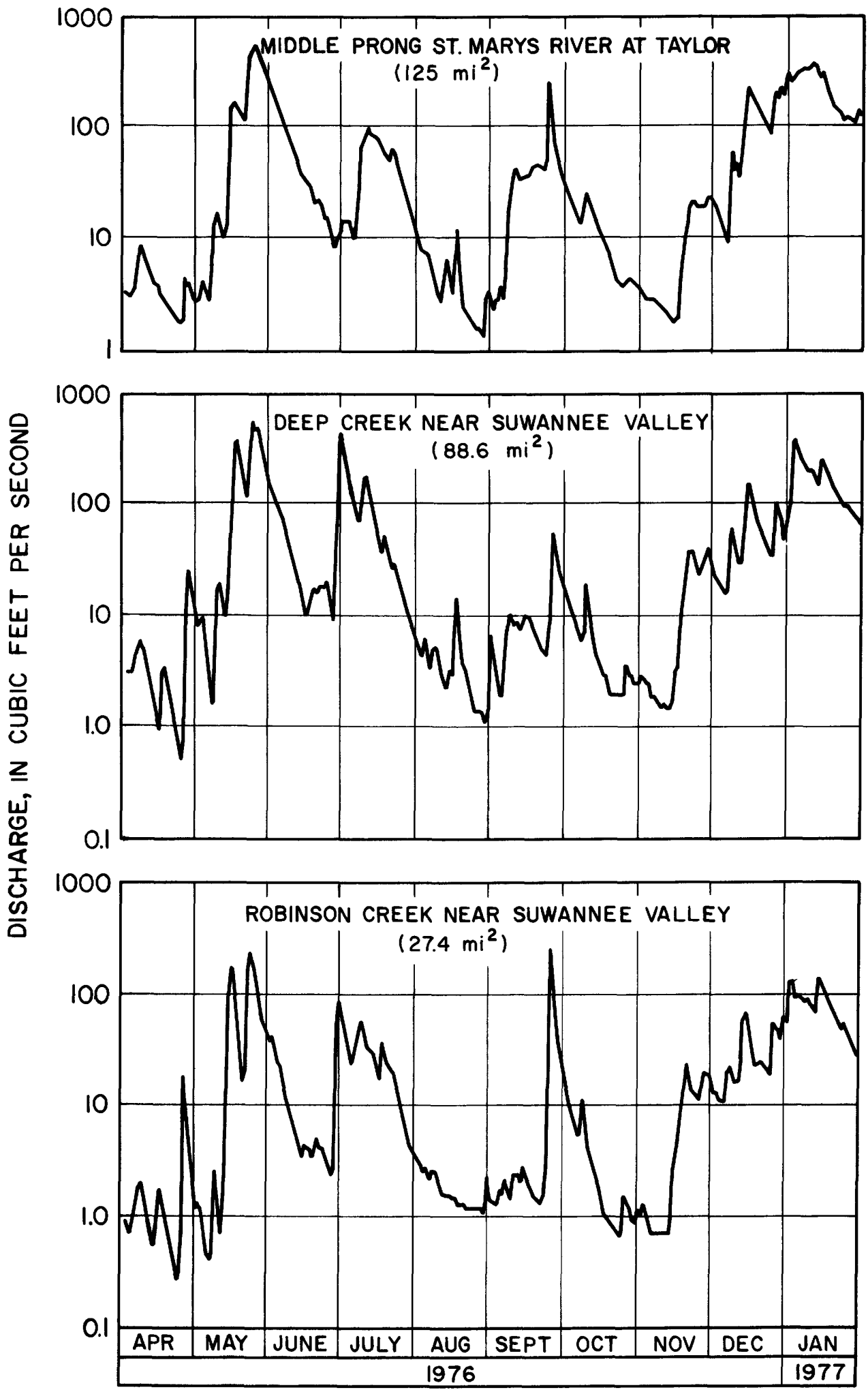

FIGURE 20.--DAILY DISCHARGE OF PRINCIPAL STREAMS DRAINING OSCEOLA NATIONAL FOREST, APRIL 1, 1976 TO JANUARY 31, 1977. (DRAINAGE AREA, IN SQUARE MILES, SHOWN IN PARENTHESES). 
During this time the monthly average discharge of Middle Prong St. Marys River in most years ranged from less than five to more than $200 \mathrm{ft}^{3} / \mathrm{s}$ as the monthly rainfall at Lake City ranged from virtually zero to 10 inches or more (fig. 17). Successive months of high rainfall produced successive months of high discharge. Variations in discharge during falling stage lag those of the rainfall by about one month, presumably because of basin storage. The yearly average discharge of Middle Prong St. Marys River correlates reasonably well with the flow of the St. Marys River near Macclenny, (fig. 18). Thus, the yearly average discharge of Middle Prong St. Marys River can be estimated from the hydrograph of the St. Marys River at Macclenny (fig. 19) which spans the years 1927-75.

During 1956-67 the average yearly discharge of Middle Prong St. Marys River at Taylor was $111 \mathrm{ft}^{3} / \mathrm{s}$; however, during this period rainfall at Lake City averaged almost 57 inches per year, considerably above the long-term average. Based on the average yearly discharge of the St. Marys River near Macclenny for 1927-75, and the relation between the discharges of the St. Marys River near Macclenny and Middle Prong St. Marys River at Taylor (fig. 18), the average yearly discharge of Middle Prong St. Marys River over the long-term is about $100 \mathrm{ft}^{3} / \mathrm{s}$, equal to $0.8 \mathrm{ft}^{3} / \mathrm{s}$ per square mile of drainage area.

The seasonal pattern of flow was similar for Deep Creek, Robinson Creek, and Middle Prong St. Marys River during this investigation as shown by the hydrographs in figure 20. The daily flow rates increased sharply with appreciable rainfall and in the absence of rainfall decreased gradually to a relatively low rate in a few days or weeks. Daily-flow data were not obtained for Falling Creek, but its flow pattern probably is similar to that of Robinson Creek insofar as the two basins are adjacent, are about the same size, and have similar basin characteristics.

In general, the peak flows per unit drainage area of Deep Creek and Robinson Creek are larger than those of Middle Prong St. Marys River. This could be due to the difference in basin slopes, which on the average are somewhat steeper for Deep and Robinson Creeks than for Middle Prong St. Marys River. The average slope of the land surface from the gaging station to the top of the drainage divide is about $5 \mathrm{ft} / \mathrm{mi}$ for Robinson Creek compared to $3 \mathrm{ft} / \mathrm{mi}$ for Middle Prong St. Marys River. In the western part of the forest, the average slope of the land surface in Deep Creek basin is about the same as that in Robinson Creek basin, but to the east the land surface is relatively flat. Overall, the land slopes in Deep Creek basin are intermediate between those in Robinson Creek basin and those in Middle Prong St. Marys River basin; thus, the peak flows would be expected to be intermediate.

During April 1976 through January 1977, runoff from Robinson Creek, Deep Creek, and Middle Prong St. Marys River averaged 0.88, 0.63, and $0.52 \mathrm{ft}^{3} / \mathrm{s}$ per square mile of drainage area, respectively. The differences in unit runoff from the various basins are assumed to result from differences in basin characteristics, rather than differences in the areal 
distribution of rainfall. The ratio between the average discharge for this 10-month period and the long-term average annual discharge is assumed to be the same for each of the streams, as well as for that part of Falling Creek that lies within the forest. Inasmuch as this ratio is known for Middle Prong St. Marys River (0.52:0.8), the average annual discharge of Robinson Creek and Deep Creek are estimated to be 1.4 and $1.0 \mathrm{ft} / \mathrm{s}$ per $\mathrm{mi}^{2}$, respectively. The average annual runoff from the part of Falling Creek basin that lies within Osceola National Forest is assumed to be the same as that for Robinson Creek, or $1.4 \mathrm{ft}^{3} / \mathrm{s}$ per $\mathrm{mi}^{2}$.

Weighted by area (table 6), the estimated average annual discharge from the 90 percent of the forest area included in Deep Creek, Robinson Creek, Falling Creek, and Middle Prong St. Marys River drainage basins is slightly less than $1.0 \mathrm{ft} 3 / \mathrm{s}$ per $\mathrm{mi}^{2}$ or about 13 inches. This value is assumed to be adequately representative of the discharge from the remaining 10 percent of the forest area included in Cedar Creek, Bluff Creek, 01ustee Creek, and South Prong St. Marys River drainage basins.

\section{Surface-Water Quality}

Surface-water quality is temporally and areally similar in the streams draining the forest. Surface-water quality was determined from samples collected monthly at the continuous-record stream-gaging stations located on Deep Creek, Robinson Creek, and Middle Prong St. Marys River. The water quality of these streams represents the surface-water quality integrated from almost all of the drainage from the forest. Small surface-water bodies, such as swamps, ponds, lakes, and streams, may exhibit areal and temporal variations from the water-quality character1stics of the principal streams, but the extent of these variations would be local and of short duration. Analyses of samples collected from the three principal streams are summarized in tables 7 and 8 .

The stream waters are similar to ground water in the upper part of the surficial aquifer with respect to dissolved inorganic ion concentrations; both have low dissolved-solids (calculated sum) concentrations compared with ground water from deeper zones. The resemblance of surfacewater quality to that of shallow ground water is greatest at times of low flow when streamflow consists almost entirely of ground-water discharge from shallow zones. At times of high flow the dissolved solids (calculated sum) concentration of streamflow is lower, reflecting the contribution of direct overland runoff.

On the other hand, these stream waters at any stage are distinctly different from any of the area's ground water with respect to concentrations of dissolved organic constituents. The surface waters of the forest are typical of southeastern United States streams that drain swamps in that they contain about equal amounts of dissolved organic and inorganic constituents (Beck and others, 1974). 
Table 7.--Summary of Selected Chemical Analyses of Water from Streams Draining Osceola National Forest.

(Concentrations are in milligrams per liter and are for dissolved constituents, except as indicated. Samples were collected on the Middle Prong St. Marys River from June 1966 through March 1977; for Deep Creek from April 1976 through March 1977; and for Robinson Creek from April 1976 through February 1977.)

\begin{tabular}{|c|c|c|c|c|c|c|c|}
\hline \multicolumn{3}{|c|}{ Samp1ing Site } & \multirow{3}{*}{ 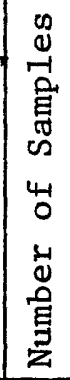 } & \multirow[b]{3}{*}{ Constituent } & \multirow{2}{*}{\multicolumn{3}{|c|}{ Concentration }} \\
\hline \multirow{2}{*}{ 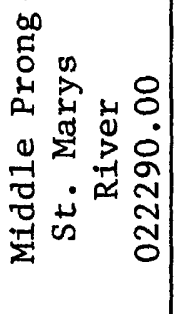 } & \multirow[b]{2}{*}{ 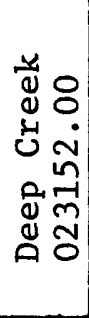 } & \multirow[b]{2}{*}{ 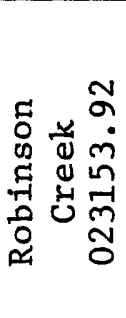 } & & & & & \\
\hline & & & & & Mean & Range & 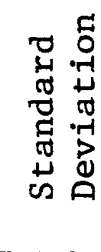 \\
\hline $\mathrm{x}$ & $\mathrm{X}$ & $\mathrm{X}$ & $\begin{array}{l}14 \\
12 \\
13\end{array}$ & Calcium (Ca) & $\begin{array}{l}2.9 \\
4.1 \\
5.2\end{array}$ & $\begin{array}{l}1.1-7.3 \\
1.8-8.6 \\
1.9-12\end{array}$ & $\begin{array}{l}1.7 \\
2.4 \\
3.7\end{array}$ \\
\hline $\mathrm{x}$ & $\mathrm{X}$ & $\mathrm{X}$ & $\begin{array}{l}14 \\
12 \\
13\end{array}$ & Magnesium (Mg) & $\begin{array}{l}1.7 \\
2.1 \\
2.7\end{array}$ & $\begin{array}{r}.6-4.0 \\
.9-4.2 \\
1.0-6.1\end{array}$ & $\begin{array}{l}1.0 \\
1.2 \\
1.9\end{array}$ \\
\hline $\mathrm{X}$ & $\mathrm{X}$ & $\mathrm{X}$ & $\begin{array}{l}14 \\
12 \\
13\end{array}$ & Sodium (Na) & $\begin{array}{l}4.1 \\
4.2 \\
4.2\end{array}$ & $\begin{array}{l}2.4-5.2 \\
3.6-5.1 \\
3.2-5.0\end{array}$ & $\begin{array}{l}.8 \\
.4 \\
.5\end{array}$ \\
\hline $\mathrm{X}$ & $\mathrm{X}$ & $\mathrm{X}$ & $\begin{array}{l}14 \\
12 \\
13\end{array}$ & Potassium (K) & $\begin{array}{l}.4 \\
.2 \\
.3\end{array}$ & $\begin{array}{l}.2-1.0 \\
.0-.3 \\
.1-.9\end{array}$ & $\begin{array}{l}.2 \\
.1 \\
.2\end{array}$ \\
\hline $\mathrm{X}$ & $\mathrm{X}$ & $\mathrm{X}$ & $\begin{array}{l}14 \\
12 \\
13\end{array}$ & Bicarbonate $\left(\mathrm{HCO}_{3}\right)$ & $\begin{array}{r}6.4 \\
9.0 \\
14\end{array}$ & $\begin{array}{l}.0-38 \\
.0-37 \\
.0-55\end{array}$ & $\begin{array}{l}11 \\
13 \\
21\end{array}$ \\
\hline $\mathrm{X}$ & $\mathrm{X}$ & $\mathrm{X}$ & $\begin{array}{l}14 \\
12 \\
13\end{array}$ & Chloride (C1) & $\begin{array}{l}7.5 \\
7.5 \\
8.6\end{array}$ & $\begin{array}{l}4.2-9.8 \\
5.7-9.7 \\
6.3-12\end{array}$ & $\begin{array}{l}1.5 \\
1.3 \\
1.7\end{array}$ \\
\hline $\mathrm{X}$ & $\mathrm{X}$ & $\mathrm{X}$ & $\begin{array}{l}14 \\
12 \\
13\end{array}$ & Sulfate $\left(\mathrm{SO}_{4}\right)$ & $\begin{array}{l}5.5 \\
7.8 \\
8.0\end{array}$ & $\begin{array}{r}.2-11 \\
.2-11 \\
4.0-13\end{array}$ & $\begin{array}{l}3.3 \\
2.9 \\
2.4\end{array}$ \\
\hline $\mathrm{X}$ & $\mathrm{X}$ & $\mathrm{X}$ & $\begin{array}{l}14 \\
12 \\
13\end{array}$ & Fluoride (F) & $\begin{array}{l}.2 \\
.2 \\
.2\end{array}$ & $\begin{array}{l}.0-.3 \\
.1-.3 \\
.1-.3\end{array}$ & $\begin{array}{l}.1 \\
.1 \\
.1\end{array}$ \\
\hline $\mathrm{X}$ & $\mathrm{x}$ & $\mathrm{X}$ & $\begin{array}{l}15 \\
12 \\
13\end{array}$ & $\mathrm{pH} 1 / 2 /$ & $\begin{array}{l}4.9 \\
5.3 \\
4.5\end{array}$ & $\begin{array}{l}3.1-6.8 \\
3.9-7.0 \\
3.9-7.1\end{array}$ & -- \\
\hline
\end{tabular}


Table 7.--Summary of Selected Chemical Analyses of Water from Streams Draining Osceola National Forest (continued).

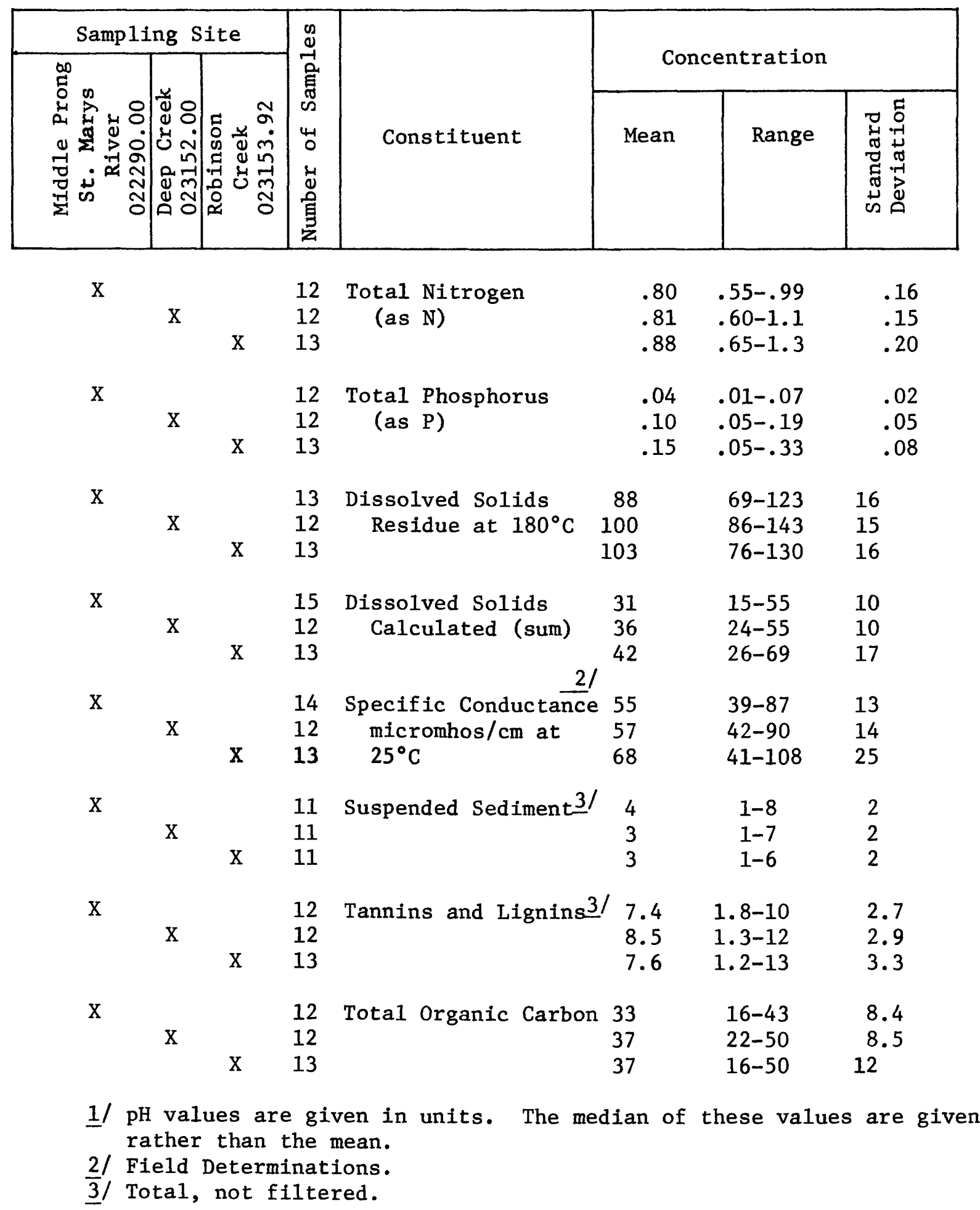


Table 8.--Summary of Selected Dissolved Trace-element Analyses of Water from Streams Draining Osceola National Forest

\begin{tabular}{|c|c|c|c|c|c|c|c|}
\hline \multicolumn{3}{|c|}{ Sampling Site } & \multirow{2}{*}{\multicolumn{5}{|c|}{$\begin{array}{c}\text { (Concentrations are in micrograms per liter, except } \\
\text { as indicated. Sampling periods are the same } \\
\text { as listed in table } 7) \text {. }\end{array}$}} \\
\hline \multirow{3}{*}{ 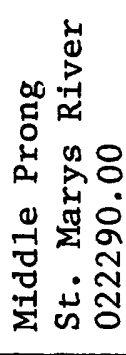 } & \multirow{3}{*}{ 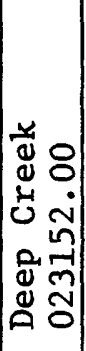 } & \multirow{3}{*}{ 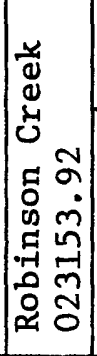 } & & & & & \\
\hline & & & \multirow{2}{*}{$\begin{array}{c}\text { Dissolved } \\
\text { Constituent }\end{array}$} & \multirow{2}{*}{ 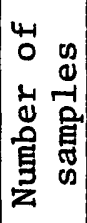 } & \multirow{2}{*}{ 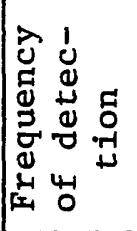 } & \multicolumn{2}{|c|}{ Concentration } \\
\hline & & & & & & Median & Range \\
\hline \multirow[t]{3}{*}{$\mathrm{x}$} & & & Aluminum & 6 & 6 & 300 & $180-420$ \\
\hline & $\mathrm{x}$ & & & 6 & 6 & 280 & $180-360$ \\
\hline & & $\mathrm{x}$ & & 6 & 6 & 360 & $130-450$ \\
\hline \multirow[t]{3}{*}{$\mathrm{X}$} & & & Arsenic & 6 & 3 & 1 & $0-1$ \\
\hline & $\mathrm{x}$ & & & 6 & 3 & 1 & $0-1$ \\
\hline & & $\mathrm{x}$ & & 6 & 2 & 0 & $0-1$ \\
\hline \multirow[t]{3}{*}{$\mathrm{x}$} & & & Barium & 6 & 4 & 100 & $0-300$ \\
\hline & $\mathrm{x}$ & & & 6 & 4 & 100 & $0-200$ \\
\hline & & $\mathrm{x}$ & & 6 & 2 & 0 & $0-200$ \\
\hline \multirow[t]{3}{*}{$\mathrm{x}$} & & & Boron & 5 & 5 & 190 & $170-290$ \\
\hline & $\mathrm{x}$ & & & 5 & 5 & 230 & $190-370$ \\
\hline & & $\mathrm{x}$ & & 5 & 5 & 210 & $160-370$ \\
\hline \multirow[t]{3}{*}{$\mathrm{x}$} & & & Cadmium & 6 & 1 & 0 & $0-7$ \\
\hline & $\mathrm{x}$ & & & 6 & 0 & 0 & 0 \\
\hline & & $\mathrm{x}$ & & 6 & 0 & 0 & 0 \\
\hline \multirow[t]{3}{*}{$\mathrm{x}$} & & & Chromium & 6 & 2 & 0 & $0-7$ \\
\hline & $\mathrm{x}$ & & & 6 & 3 & 1 & $0-2$ \\
\hline & & $\mathrm{x}$ & & 6 & 2 & 0 & $0-5$ \\
\hline \multirow[t]{3}{*}{$\mathrm{x}$} & & & Cobalt & 6 & 1 & 0 & $0-3$ \\
\hline & $\mathrm{X}$ & & & 6 & 1 & 0 & $0-2$ \\
\hline & & $\mathrm{x}$ & & 6 & 1 & 0 & $0-3$ \\
\hline \multirow[t]{3}{*}{$\mathrm{x}$} & & & Copper & 6 & 3 & 1 & $0-6$ \\
\hline & $\mathrm{x}$ & & & 6 & 3 & 1 & $0-6$ \\
\hline & & $\mathrm{x}$ & & 6 & 2 & 0 & $0-5$ \\
\hline \multirow[t]{3}{*}{$\mathrm{x}$} & & & Iron & 8 & 8 & 540 & $50-790$ \\
\hline & $\mathrm{X}$ & & & 6 & 6 & 640 & $490-810$ \\
\hline & & $\mathrm{X}$ & & 6 & 6 & 720 & $380-820$ \\
\hline
\end{tabular}


Table 8.--Summary of Selected Dissolved Trace-element Analyses of Water from Streams Draining Osceola National Forest (continued).

\begin{tabular}{|c|c|c|c|c|c|c|c|}
\hline \multicolumn{3}{|c|}{ Sampling Site } & & & & & \\
\hline \multirow{3}{*}{ 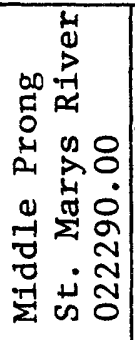 } & \multirow{3}{*}{ 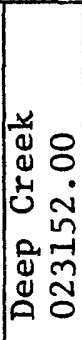 } & \multirow{3}{*}{ 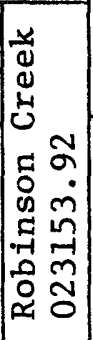 } & & & & & \\
\hline & & & & $\begin{array}{cc}4 & \\
0 & 0 \\
& 0 \\
1 & -1 \\
0 & 0 \\
0 & 0\end{array}$ & 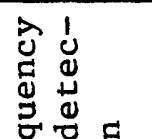 & \multicolumn{2}{|c|}{ Concentration } \\
\hline & & & Constituent & $\sum^{3}$ in & 虫㟧至 & Median & Range \\
\hline \multirow[t]{3}{*}{$X$} & & & Lead & 6 & 6 & 7 & $4-36$ \\
\hline & $\mathrm{X}$ & & & 6 & 6 & 7 & $3-12$ \\
\hline & & $\mathrm{X}$ & & 6 & 6 & 8 & $3-16$ \\
\hline \multirow[t]{3}{*}{$\mathrm{X}$} & & & Lithium & 6 & 0 & 0 & 0 \\
\hline & $\mathrm{X}$ & & & 6 & 0 & 0 & 0 \\
\hline & & $\mathrm{x}$ & & 6 & 0 & 0 & 0 \\
\hline \multirow[t]{3}{*}{$\mathrm{x}$} & & & Manganese & 7 & 6 & 20 & $0-60$ \\
\hline & $\mathrm{X}$ & & & 6 & 6 & 20 & $10-40$ \\
\hline & & $\mathrm{X}$ & & 6 & 5 & 20 & $0-40$ \\
\hline \multirow[t]{3}{*}{$\mathrm{X}$} & & & Mo1ybdenum & 6 & 2 & 0 & $0-4$ \\
\hline & $\mathrm{X}$ & & & 6 & 3 & 1 & $0-3$ \\
\hline & & $\mathrm{X}$ & & 6 & 2 & 0 & $0-2$ \\
\hline \multirow[t]{3}{*}{$\mathrm{X}$} & & & Nickel & 6 & 1 & 0 & $0-2$ \\
\hline & $\mathrm{X}$ & & & 6 & 1 & 0 & $0-3$ \\
\hline & & $\mathrm{X}$ & & 6 & 2 & 0 & $0-1$ \\
\hline \multirow[t]{3}{*}{$\mathrm{x}$} & & & Strontium & 13 & 12 & 40 & $0-60$ \\
\hline & $\mathrm{X}$ & & & 12 & 12 & 40 & $10-80$ \\
\hline & & $\mathrm{X}$ & & 13 & 13 & 40 & $10-80$ \\
\hline \multirow[t]{3}{*}{$\mathrm{X}$} & & & Uranium & 2 & 2 & .03 & $.01-.04$ \\
\hline & $\mathrm{X}$ & & & 2 & 2 & .07 & $.06-.07$ \\
\hline & & $\mathrm{X}$ & & 1 & 1 & - & .08 \\
\hline \multirow[t]{3}{*}{$\mathrm{X}$} & & & Vanadium & 6 & 1 & .0 & $.0-5.4$ \\
\hline & $\mathrm{X}$ & & & 6 & 1 & .0 & $.0-9.6$ \\
\hline & & $\mathrm{X}$ & & 6 & 1 & .0 & 8.9 \\
\hline \multirow[t]{3}{*}{$\mathrm{X}$} & & & Zinc & 6 & 4 & 20 & $0-30$ \\
\hline & $\mathrm{X}$ & & & 6 & 3 & 5 & $0-30$ \\
\hline & & $\mathrm{X}$ & & 6 & 5 & 10 & $0-10$ \\
\hline \multirow[t]{3}{*}{$\mathrm{X}$} & & & Radium-2261 & 16 & 6 & .08 & $.03-.14$ \\
\hline & $\mathrm{X}$ & & & 5 & 5 & .06 & $.02-.10$ \\
\hline & & $\mathrm{X}$ & & 6 & 6 & .07 & $.01-.20$ \\
\hline
\end{tabular}

I/ Concentration in picocuries per liter. 
of the water-quality properties determined, only dissolved solids calculated sum, organic carbon, and tannins and lignins correlated significantly with discharge for all three forest streams. In general, dissolved inorganic solids (calculated sum) concentration decreases with increased streamflow reflecting the higher proportion of less mineralized direct overland runoff to that of ground-water discharge (fig. 21). To the contrary, the total organic carbon concentrations and concentrations of tannins and 1ignins increase with increasing stream flow, reflecting the flushing of ponded swamp waters. Consequent1y, the dissolved solids (residue) shows no or only a poor correlation with streamflow because of the counteracting tendency of these two relations. Overa11, the organic material flushed from the swamps and marshlands, particularly during rainstorms, accounts for the differences between the two dissolved solids determinations because the organics are not included in the "sum" determination, but are included in the "residue" determinations.

Constituent concentrations found to be influenced by phosphate industry operations are phosphorous, nitrogen, sulfate, fluoride, tannins and 1ignins, organic carbon, radium-226, and suspended sediment. Thus, baseline concentrations of these constituents are described below for the three forest streams.

Total phosphorous, almost entirely in the form of orthophosphate, ranged in concentration from 0.01 to $0.33 \mathrm{mg} / \mathrm{L}$ (as $P$ ), and decreased slightly in concentration with increased streamflow in each of the three streams.

Total nitrogen represents all nitrogen forms but consists mainly of organic nitrogen as determined by the Kjeldahl nitrogen method. Ammonia, nitrite, and nitrate nitrogen each are less than $0.10 \mathrm{mg} / \mathrm{L}$. Organic nitrogen results from decaying flora and fauna in swamp water discharged at higher flows.

Sulfate ranged in concentration from 0.2 to $13 \mathrm{mg} / \mathrm{L}$, with mean concentrations slightly higher in the western part of the forest than in the eastern part. Fluoride concentrations ranged from 0.0 to $0.3 \mathrm{mg} / \mathrm{L}$. The concentrations of fluoride, like sulfate, did not have a simple relation with streamflow.

The concentrations of tannins and 1ignins and of total organic carbon are similar in all three streams. Total organic carbon ranged from 16 to $50 \mathrm{mg} / \mathrm{L}$ and tannins and 1ignins ranged from 1.2 to $13 \mathrm{mg} / \mathrm{L}$. As the organic carbon concentration increases with the organic content of the streams, the $\mathrm{pH}$ decreases. The $\mathrm{pH}$ values ranged from 3.1 to 7.1 , but median values are near 5.0 in all three streams.

Radium-226 concentrations ranged from 0.01 to $0.20 \mathrm{pCi} / \mathrm{L}$ and exhibit no apparent relation areally or temporally to streamflow variations (table 8). The concentrations of other trace elements are 1isted in table 8 , but are not discussed here. 

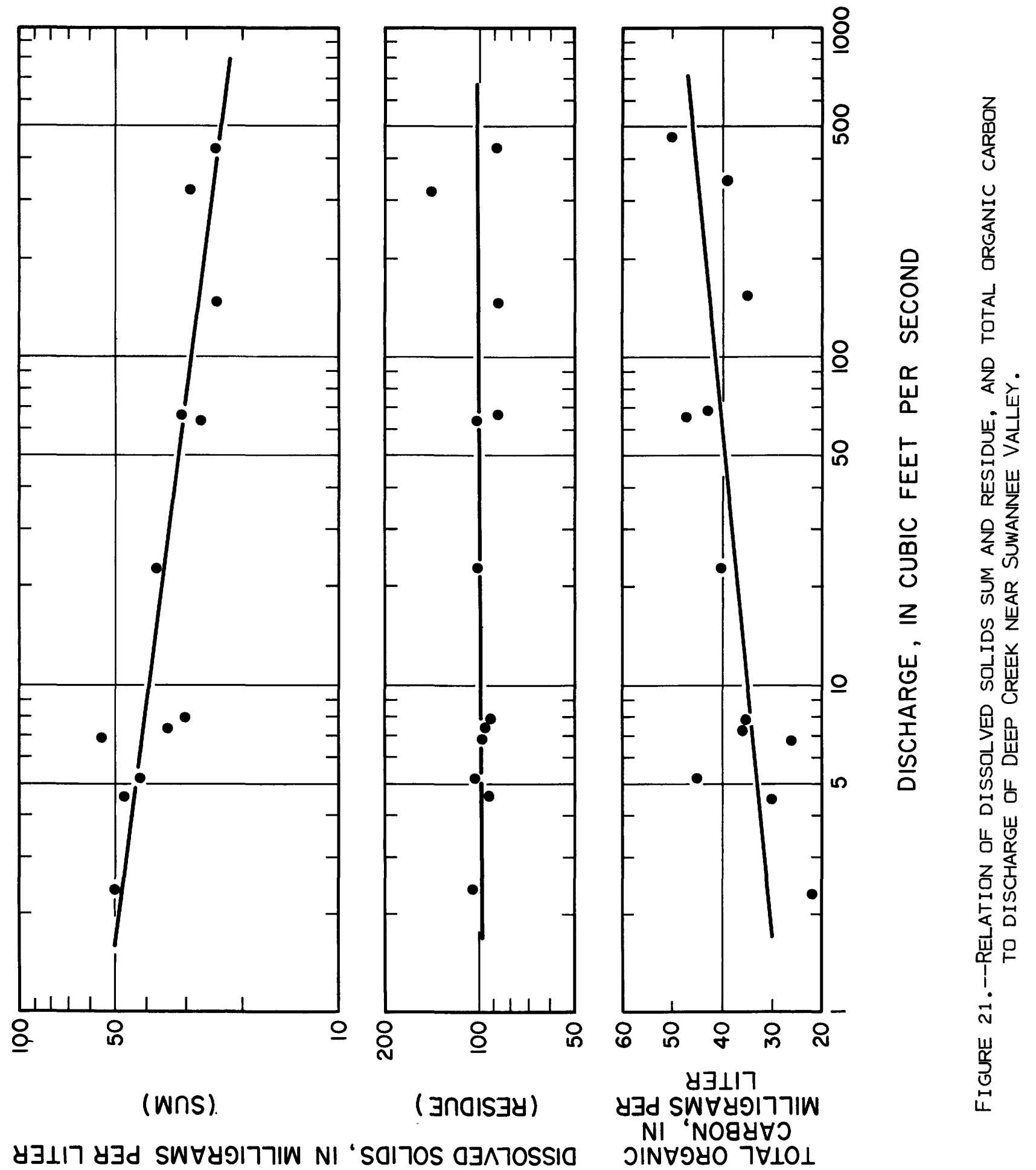
Suspended-sediment concentrations in the three forest streams ranged from 1 to $8 \mathrm{mg} / \mathrm{L}$ and were a small part of the total stream loads, which averaged 0.01 tons/day per $\mathrm{mi}^{2}$ for the area. Correlation of suspended solids concentration with streamflow was not statistically significant. The dissolved-solids loads for the three streams, based on mean concentrations, made up more than 95 percent of the total stream loads. The dissolved-solids loads for Robinson Creek, Deep Creek, and Middle Prong St. Marys River, using the mean residue values, were 0.24 , 0.17 , and 0.12 tons/day per $\mathrm{mi}^{2}$, respectively. The differences in dissolved load reflect the differences in mean discharges.

The stream waters in the Osceola National Forest are thus characterized by a relatively low inorganic-ion content, an organic content about equal to the inorganic content, relatively low suspended-sediment content even at high flows, an acidic nature, and a general lack of statistically significant correlation of most individual parameters with variations in discharge. The tendency is for the inorganic constituents to decrease in concentration as streamflow increases and for the organics to increase in concentration. Ground-water discharge from the surficial aquifer contributes significantly to the quantity and quality of streamflow, whereas ground-water from deeper-lying hydrogeologic units does not. Rainfa11 probably contributes a large amount of the major dissolved inorganic ions, particularly during high streamflow. Decaying flora and fauna contribute to the organic material. The dense vegetation cover and low land-surface gradient throughout the forest account for the low suspended-sediment load of the streams.

\section{Ground Water}

Hydrogeologic Units

The ground-water system beneath Osceola National Forest consists of, in descending order, the unconfined surficial aquifer, the Hawthorn confining unit, and the confined Floridan aquifer. The relationship of these hydrogeologic units to geologic units encountered in test drilling is shown on table 9 .

Within the forest the surficial aquifer is composed of post-Miocene unconsolidated sediments and the A member, or uppermost part, of the Hawthorn Formation of Miocene age. The underlying Hawthorn strata, members B-E, comprise the Hawthorn confining unit, which lies between and hydraulically separates the surficial aquifer from the Floridan aquifer. The part of the Floridan aquifer underlying the forest which is believed to contain freshwater consists of, in descending order, the Ocala, Avon Park, and Lake City Limestones, al1 of Eocene age. 


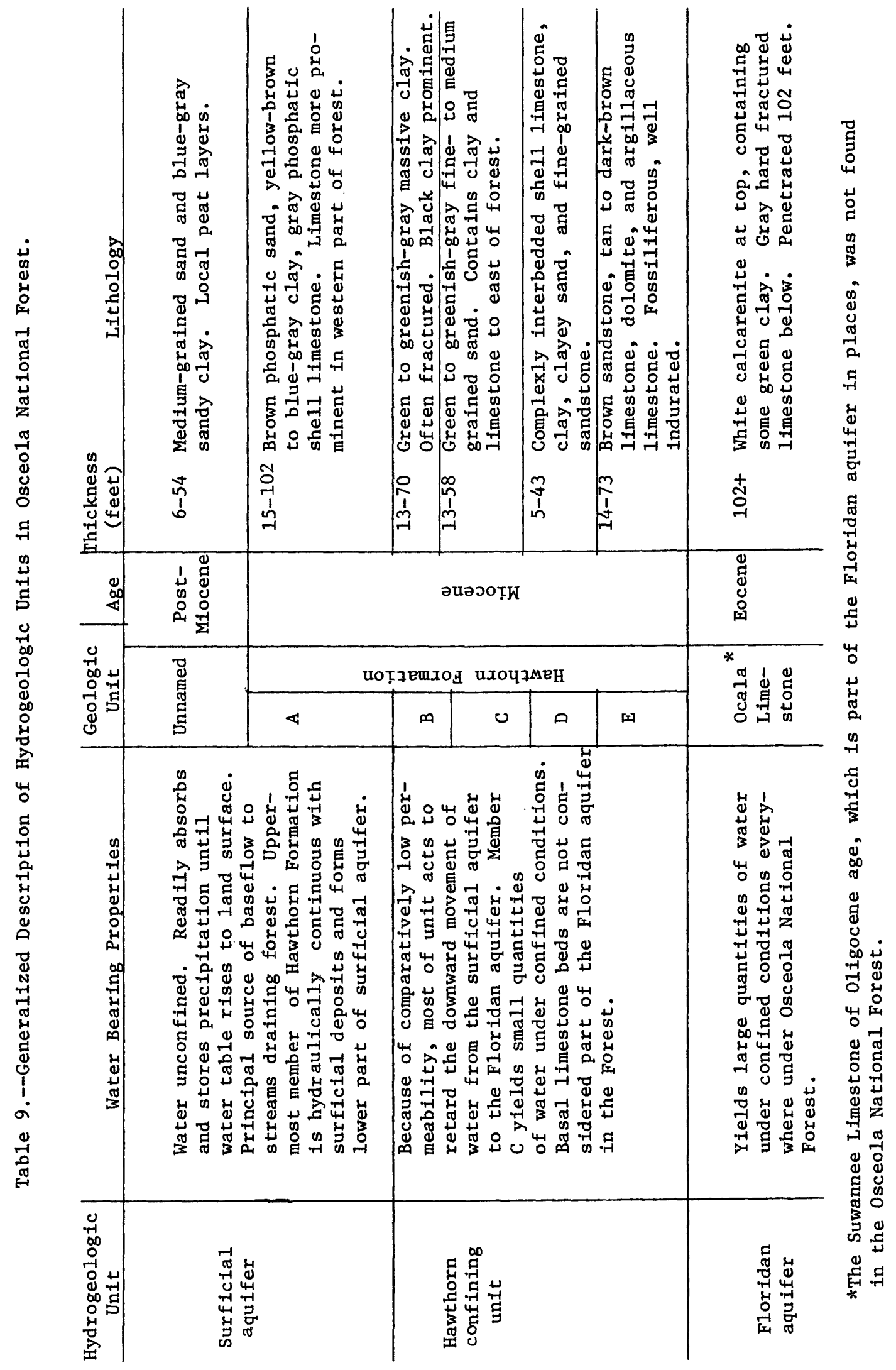




\section{Surficial Aquifer}

The surficial aquifer consists of two distinct lithologic units that have similar hydrologic characteristics. The upper part of this aquifer consists of unconsolidated fine- to medium-grained sand, with minor amounts of clay, admixed and as beds, and thin peat layers near the surface. The exact age of these materials is not known, but they are younger than Miocene. They lie disconformably on member A of the Hawthorn Formation, which constitutes the lower part of the aquifer. Member A in the western part of the forest consists mostly of poorly sorted phosphatic sands, clayey sands, and argillaceous 1imestone. Eastward, the amount of clay in the unit increases, the sand is better sorted and medium-grained, and less limestone is present. A gray, phosphatic, shell 1imestone is found in the basal few feet of member A in most places. Even though it is somewhat different lithologically from overlying deposits, member $A$ is included as part of the surficial aquifer because water levels in wells tapping it are virtually identical in altitude to those of the upper part of the aquifer, and they respond to stresses in the same way as the water table.

The surficial aquifer occurs throughout the forest and ranges in thickness from 42 feet at well 14 at Lake City to 156 feet at well 11 at Taylor (fig. 22). The steady rate of northeastward thickening of the aquifer is interrupted by irregularities just to the northeast of Lake City. These features are due to variations in thickness of the lower (member A) part of the aquifer.

Water in the surficial aquifer is under unconfined or water-table conditions. The water table is generally a subdued replica of the topography and lies at or within a few feet of land surface nearly everywhere in the forest. Its general configuration, based on topographic maps, is shown on figure 23. Rainfall readily infiltrates the surficial aquifer and moves downward to the water table, at which point its movement becomes predominantly lateral. From a ground-water divide, which underlies a topographic high extending eastward from Lake City along the southern and southeastern boundary of the forest, water in the surficial aquifer moves generally northerly across the forest toward the major drainage courses. This lateral movement is interrupted 1ocally by smaller streams, lakes, and swamps into which the ground water discharges. Other major discharge from the surficial aquifer is by evaporation and transpiration where the water table is at or near land surface. Pumpage from scattered domestic wells accounts for a minor amount of aquifer discharge. The water levels in the surficial aquifer everywhere in the forest are at higher altitudes than the potentiometric surface of either the Floridan aquifer or the permeable beds of the Hawthorn confining unit. Thus, some discharge from the surficial aquifer also occurs by downward leakage. However, the amount of leakage is shown to be low later in this report. 


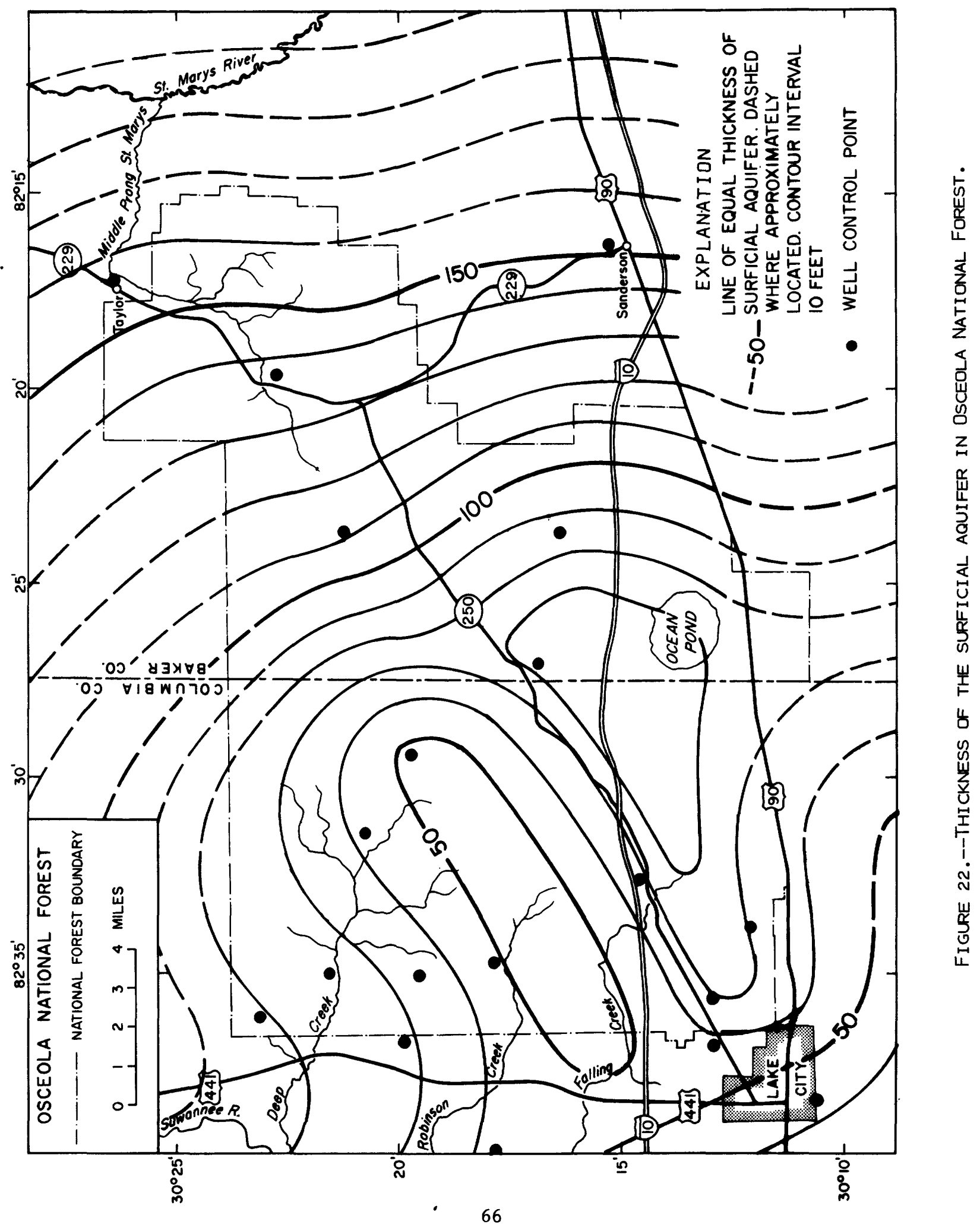




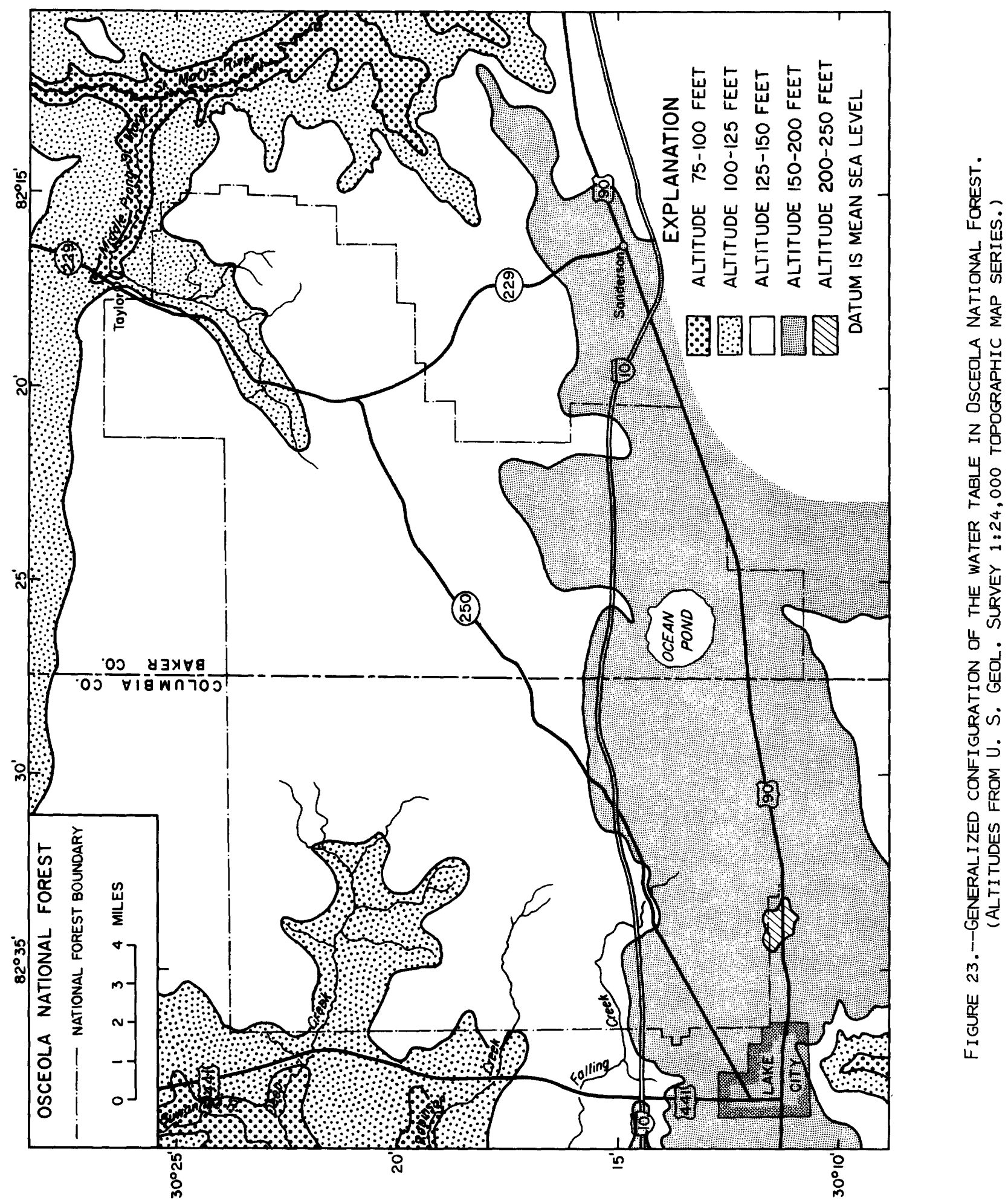


Water levels in the surficial aquifer respond directly and rapidly to variations in rainfall; they rise abruptly during periods of rainfall, and decline gradually during dry periods. The hydrographs reproduced as figure 24 show the response of the aquifer to dry periods in August and early November that were followed by periods of steady rainfall.

The surficial aquifer is used as a source of supply for some of the private residences which are scattered in the forest. Wells screened in the sand of the upper part of the aquifer yield small amounts of water.

The chemical character of ground water in the surficial aquifer in Osceola National Forest varies vertically in accordance with vertical lithologic changes in the aquifer, particularly between water in the post-Miocene deposits and water in the A member. Lateral variability in ground-water quality within these units is less defined, but lateral changes are probably not as great as vertical changes because the lithology of the aquifer varies less laterally than vertically.

Test wells screened in the upper part of the surficial aquifer (post-Miocene deposits) yield water with $\mathrm{pH}^{\prime} \mathrm{s}$ ranging from 4.5 to 6.2 , specific conductance from 50 to $84 \mu \mathrm{mhos} / \mathrm{cm}$, and dissolved solids (sum) concentrations from 32 to 46 (table 10). Dissolved constituents are low in concentration and the chemical character is of the "mixed" type with no major ions dominating. Organic material occurs in some wells tapping the uppermost part of the surficial aquifer with the acidic $\mathrm{pH}^{\prime} \mathrm{s}$ of the water reflecting its presence. Well 1B (table 10) bottoms at the top of member A but yields water similar in chemical quality to that of water from member A.

The lower part of the surficial aquifer--member A of the Hawthorn Formation--varies considerably in thickness laterally and in 1ithology vertically as well as laterally. These lithologic variations are reflected to some extent in the chemistry of the water (table 10). The upper part of member A is mostly a phosphatic, quartzose-to-calcareous sand, whereas the lower part is primarily a limestone or dolomite containing minor amounts of phosphatic material. The upper part of member A (well 2I, 2S) yields water intermediate in quality between that higher in the surficial aquifer and that in the lower part of member $A$ (we1ls $2 H, 2 R$, 6B), except for phosphate and fluoride concentrations which are highest in water from the upper part of member $A$. The comparatively high phosphate and fluoride concentrations reflect the occurrence there of phosphate ore. Water throughout member A is of the "calcium magnesium bicarbonate" type.

Radioactive nuclides and most trace elements are present in low concentrations (table 11). Iron, zinc and strontium have the highest concentrations of the metals. The upper part of the surficial aquifer has higher concentrations of zinc and lower concentrations of strontium than member $A$. 


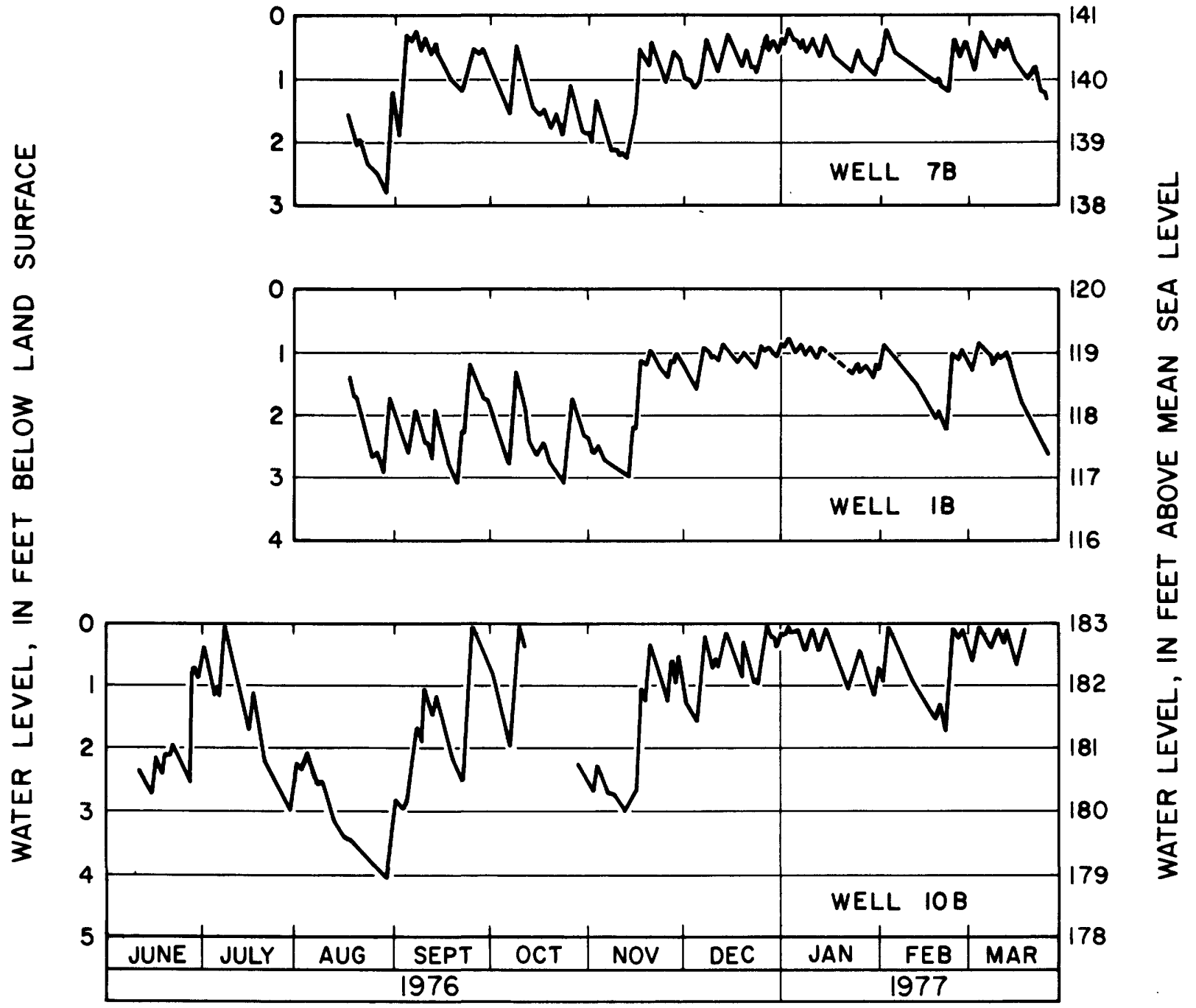

FIGURE 24.--HYDROGRAPHS OF WELLS THAT TAP THE SURFICIAL AQUIFER. 


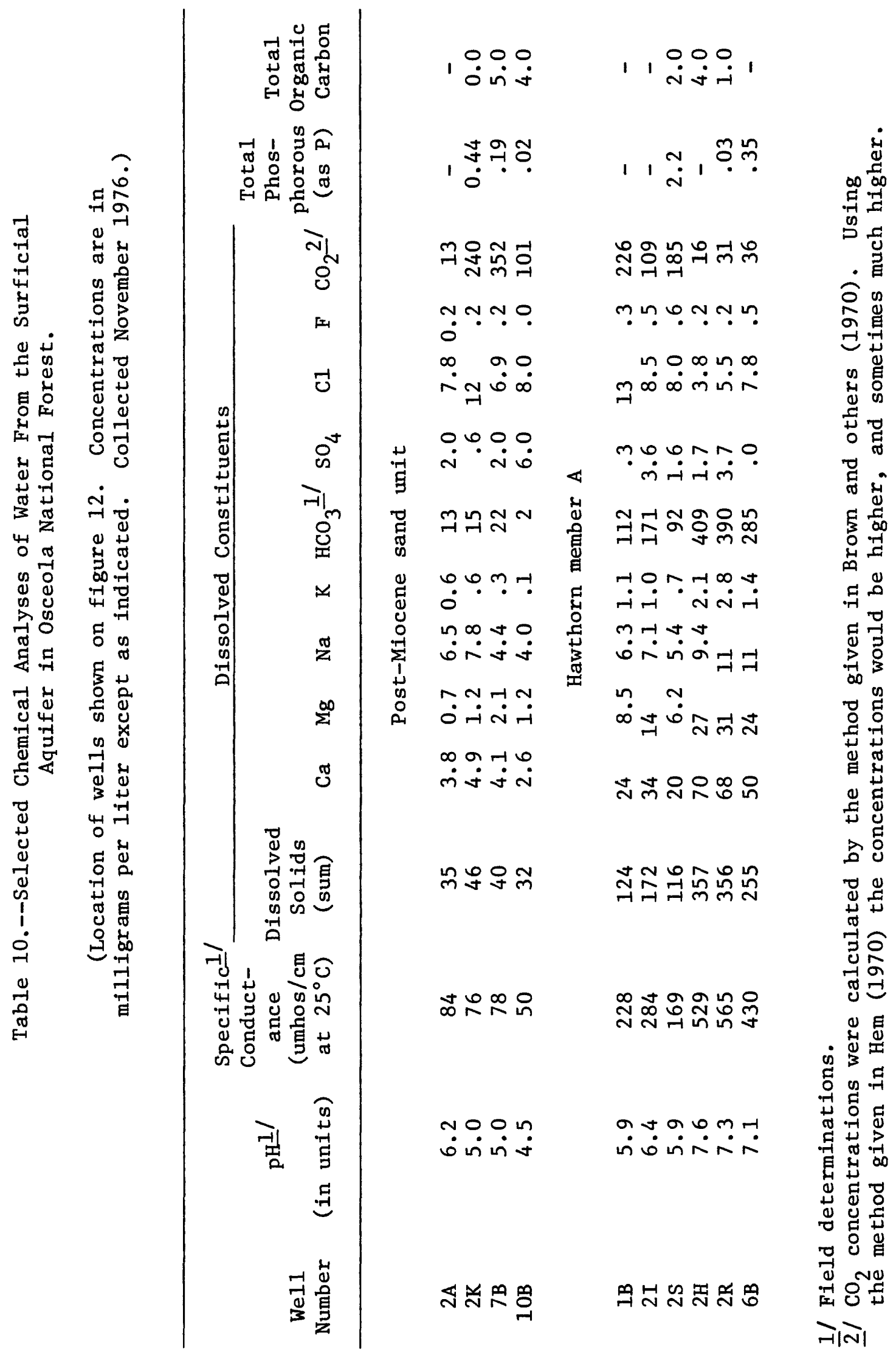



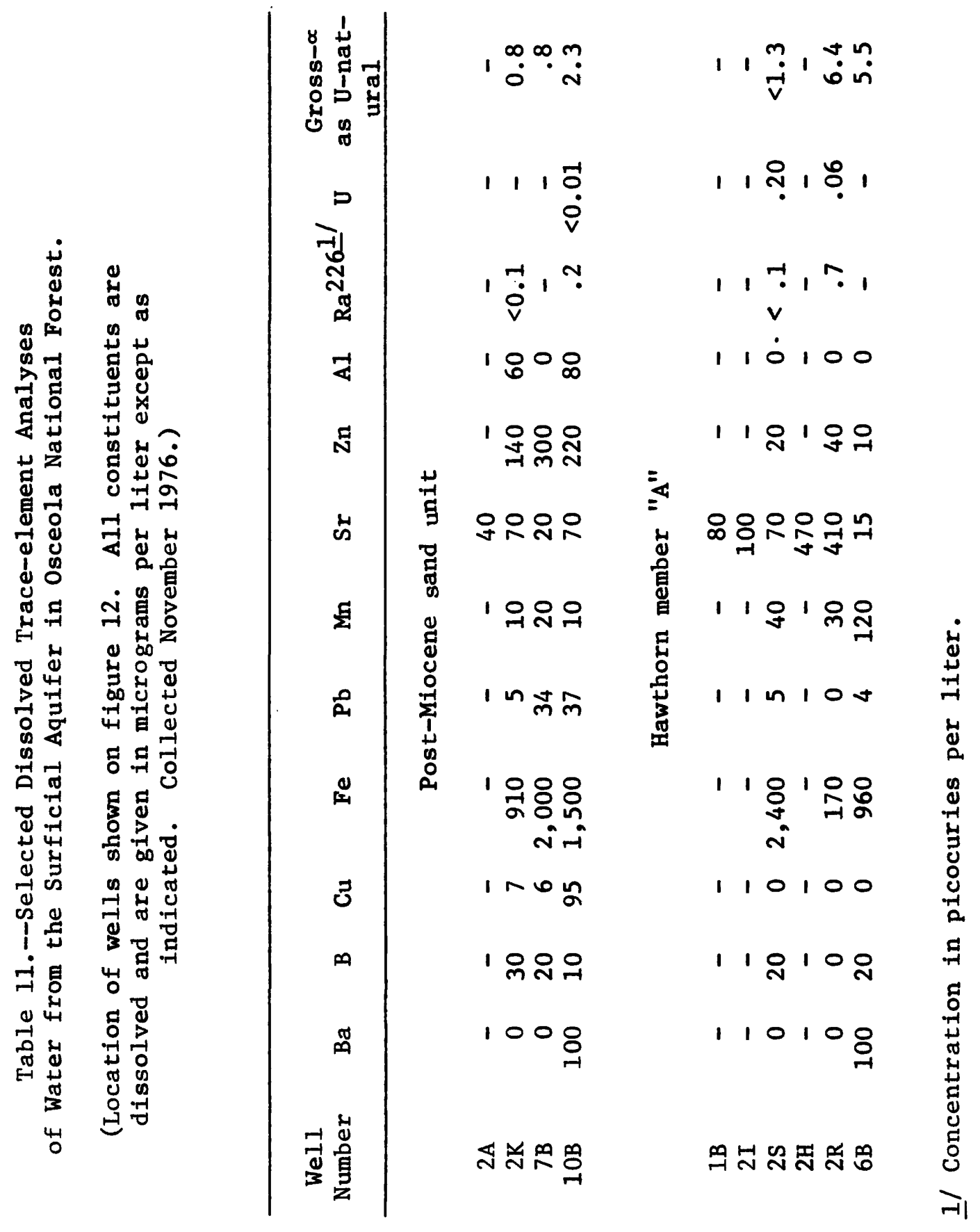
Fertilization to stimulate tree growth has been used in Osceola National Forest on a limited basis by the U.S. Forest Service. The last application was in 1972 when selected areas of seedling and young trees were treated with 300 pounds per acre of cogranular ground phosphate rock.

According to Don Percival (U.S. Forest Service, Tallahassee, Fla., written commun., Oct. 13, 1977), the application of chemical fertilizers to forest stands on the Osceola National Forest will continue in the future on a limited basis. The effect of these practices on the chemical quality of water from the surficial aquifer is unknown.

\section{Hawthorn Confining Unit}

The informally designated Hawthorn members B through E (table 9) comprise the Hawthorn confining unit, which underlies the surficial aquifer everywhere in Osceola National Forest. Except for a moderately permeable fine- to medium-grained sand (member $C$ ) near the middle of the confining unit, these strata consist of clay, sandy clay, fine-grained sandstone, and sandy to argillaceous limestone--all of low permeability. The clay content of the entire confining unit is greatest in the eastern part of the forest.

From a minimum known thickness of 52 feet at Lake City, the Hawthorn confining unit thickens gradually in a northeast direction to a maximum known thickness of 234 feet near Taylor (fig. 25). Local thickening and thinning of the unit east and northeast of Lake City is the result of differential compaction and post-depositional erosion, rather than structural warping. The Hawthorn confining unit pinches out within a few miles southwest of Lake City. The Suwannee River has cut completely through the confining unit into the underlying Floridan aquifer to the west of the forest where the Hawthorn thins to less than 50 feet.

The uppermost subdivision of the Hawthorn confining unit (member B -table 9) is a massive clay whose low permeability serves to confine the water in all lower permeable zones, thereby creating artesian conditions in them. Altitudes of the potentiometric surfaces of the several zones in the Hawthorn decrease directly with depth of the zone, but they are everywhere intermediate between the water table and the Floridan aquifer. Two wells tapping Hawthorn member $C$ have static water levels of about 100 feet altitude--about 40 feet below the water table and about 40 feet above the potentiometric surface of the Floridan. This downward gradient shows that leakage from the surficial aquifer through the Hawthorn confining unit to the Floridan aquifer is 1ikely.

Because of the hydraulic potential for downward leakage of water through the Hawthorn, cation-exchange capacity determinations were made on selected core samples of all of the members comprising the Hawthorn Formation except member $C$. These results are listed in table 12 . As expected, member $B$, which is predominantly clay, has the highest cation- 


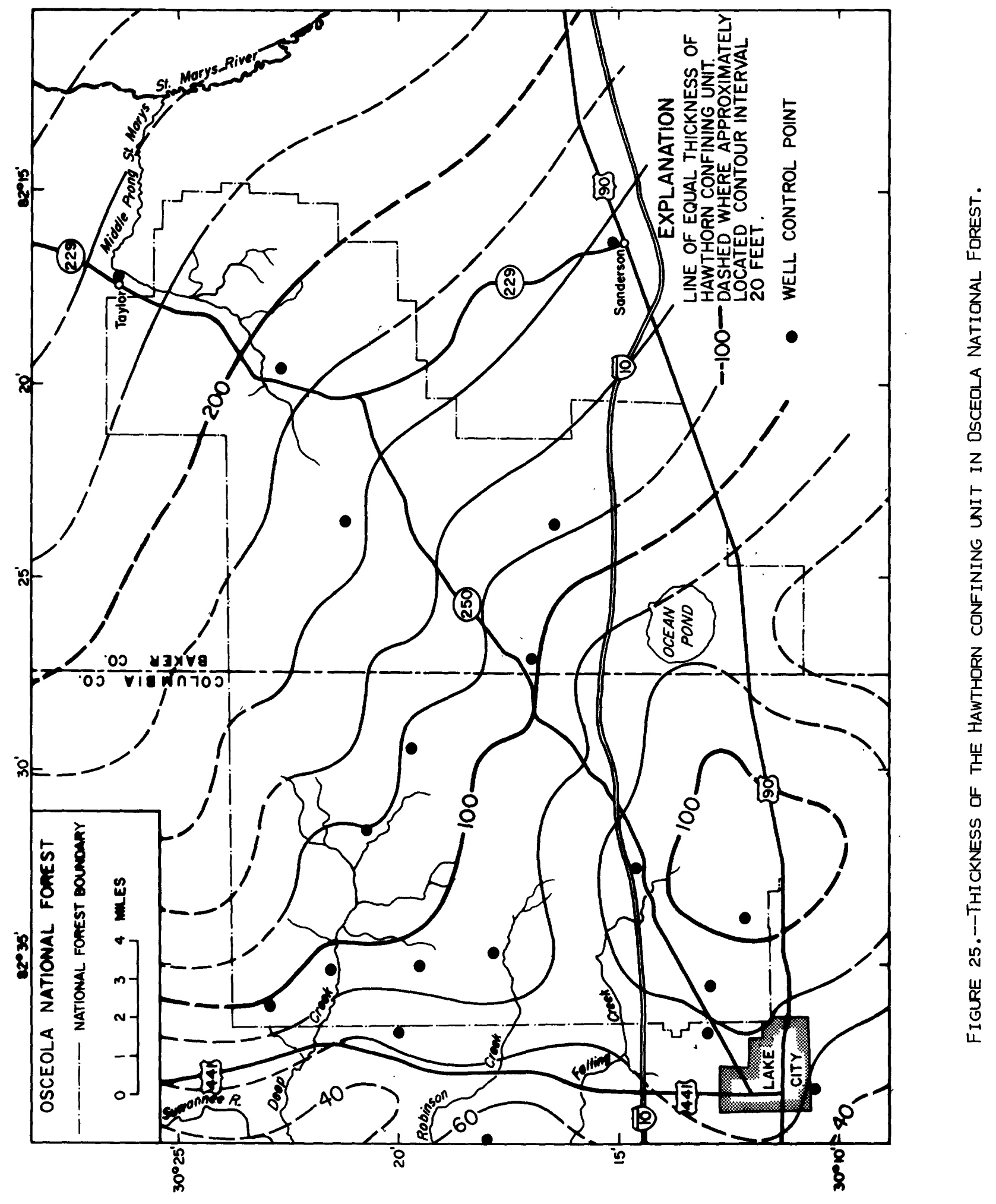


Table 12.--Cation Exchange Capacity of Core Samples from Selected Lithologic Units at Well $2 \mathrm{~V}$.

\begin{tabular}{ccccc}
$\begin{array}{c}\text { Sample } \\
\text { Number }\end{array}$ & $\begin{array}{c}\text { Depth Interva1 } \\
\text { (feet below } \\
\text { land surface) }\end{array}$ & $\begin{array}{c}\text { Hawthorn } \\
\text { Member }\end{array}$ & & $\begin{array}{c}\text { Cation } \\
\text { Exchange } \\
\text { Capacity } \\
\text { (meg/100g) }\end{array}$ \\
\cline { 2 - 3 } 2 & $53-55.5$ & A & 9.4 \\
3 & $76-78$ & B & 20 \\
4 & $94-96$ & B & 30 \\
5 & $125.8-127.8$ & D & 3.4 \\
6 & $134.9-136.2$ & D & 1.3 \\
7 & $137.0-139.0$ & E & 5.1 \\
$147.9-149.9$ & E & 9.7
\end{tabular}


exchange capacity. However, all of the determinations were in the low range of values reported for clays by Grim (1962, p. 30).

Water levels in a well tapping member $C$ (fig. 26) reflect the availability of recharge from precipitation after evapotranspiration losses are satisfied. The general response of this unit to recharge is very similar to that of the Floridan aquifer (compare with fig. 29) but the range of fluctuation of water levels in member $C$ is only 3 feet, compared with as much as 9 feet in some Floridan wells (f1g. 29), based on 10 months of record.

As far as is known, the Hawthorn confining unit is not used as a source of supply anywhere in the forest except at a U. S. Forest Service installation south of Taylor. Wells in the overlying surficlal aquifer provide amounts of water adequate for domestic purposes, and the underlying Floridan aquifer provides large yields where desired. Wells screened in member $C$ can yield 2 to 3 gallons per minute, as determined by an aquifer test of member $\mathrm{C}$ at site 2 .

Data on the chemical character of water from members $\mathrm{C}$ and $\mathrm{E}$ of the Hawthorn confining unit are given in tables 13 and 14 . Test wells completed in the other units either had yields too low to permit sampling, or could not be developed sufficiently to obtain a satisfactory sample. Water from member $\mathrm{C}$ ranges in $\mathrm{pH}$ from 6.8 to 7.4 , in specific conductance from 420 to $551 \mu \mathrm{mhos} / \mathrm{cm}$, and in dissolved solids (sum) concentrations from 259 to $361 \mathrm{mg} / \mathrm{L}$. Values of these parameters for the sample from member $\mathrm{E}$ are near the upper end of the ranges for member $\mathrm{C}$.

Water from members $\mathrm{C}$ and $\mathrm{E}$ of the Hawthorn confining unit has fluoride concentrations ranging from 0.1 to $0.5 \mathrm{mg} / \mathrm{L}$. Total phosphorous concentrations (as P) range from 0.04 to $0.20 \mathrm{mg} / \mathrm{L}$. Radium-226 concentrations are higher in the Hawthorn than in the surficial aquifer. Iron and strontium are the most abundant trace elements (table 14). Water from the Hawthorn confining unit is chemically similar to that of member $A$ of the surficial aquifer -- both are of the "calcium magnesium bicarbonate" type.

\section{Floridan Aquifer}

The Floridan aquifer underlies the Hawthorn confining unit throughout Osceola National Forest. The strata comprising the Floridan consist of a thick and regionally extensive series of interbedded 1imestones and dolomites that vary vertically and horizontally in porosity and permeability.

Within the forest the top of the Floridan aquifer is the top of the Ocala Limestone of late Eocene age (table 9) and its altitude is shown on figure 13. The base of the Floridan, as used in this report, is the base of the Cedar Keys Limestone of Paleocene age (table 3). A11 rock 


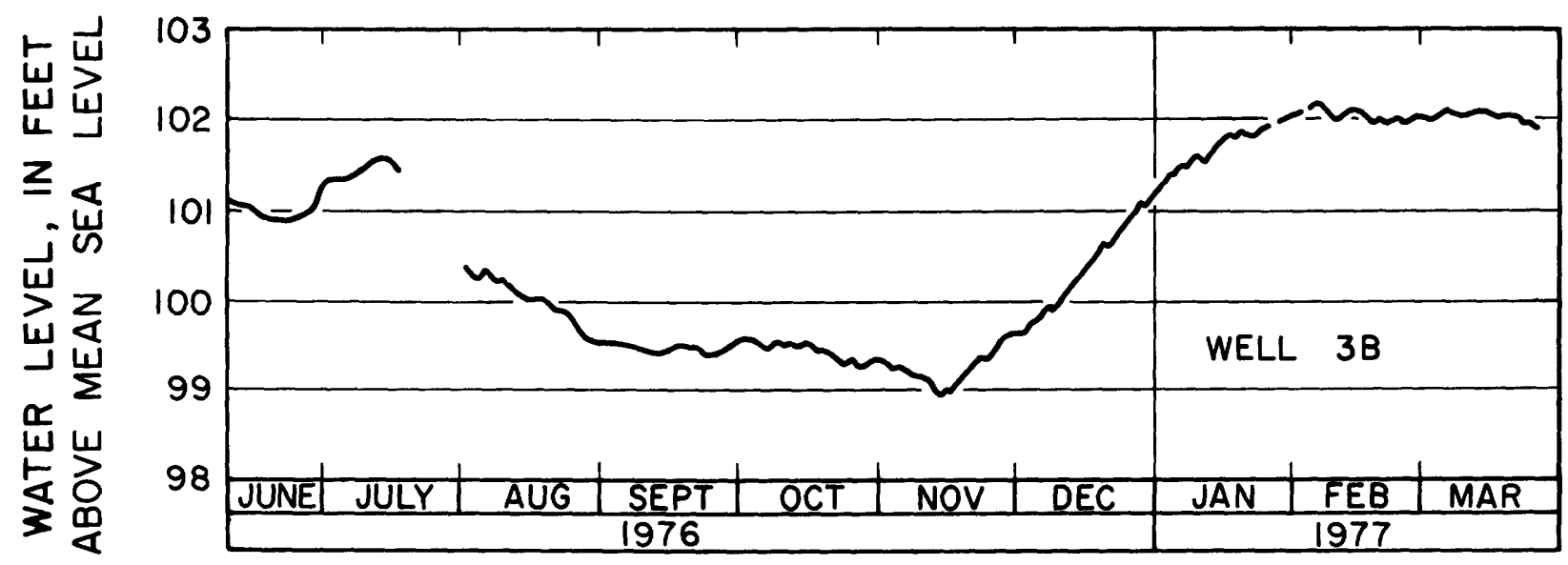

FIGURE 26.--HYDROGRAPH OF WELL 3B THAT TAPS A SAND NEAR THE MIDDLE OF THE HAWTHORN CONFINING UNIT. 


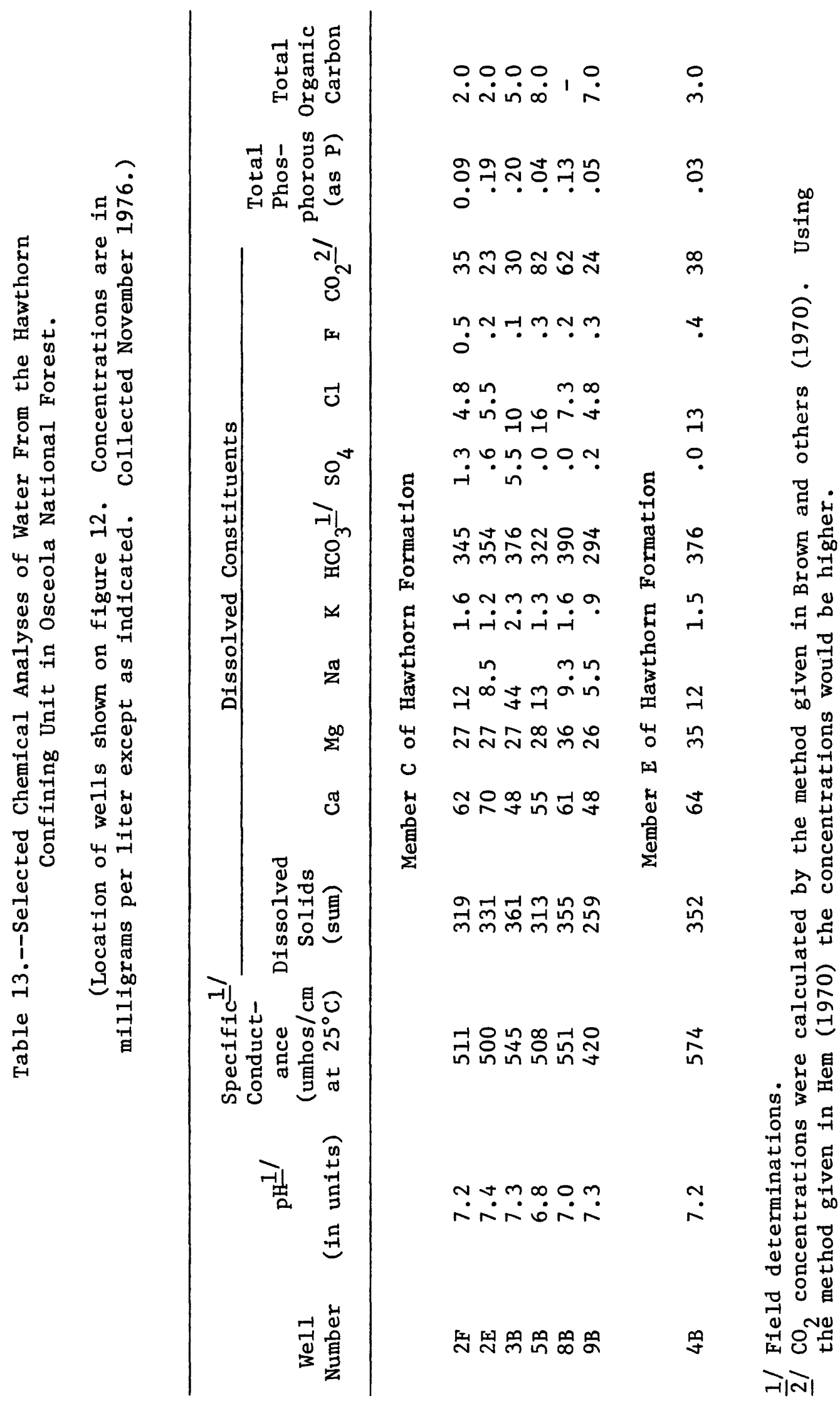




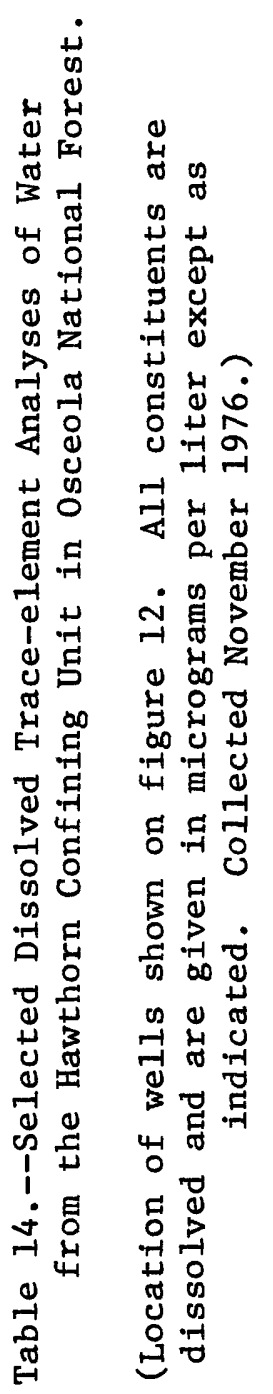

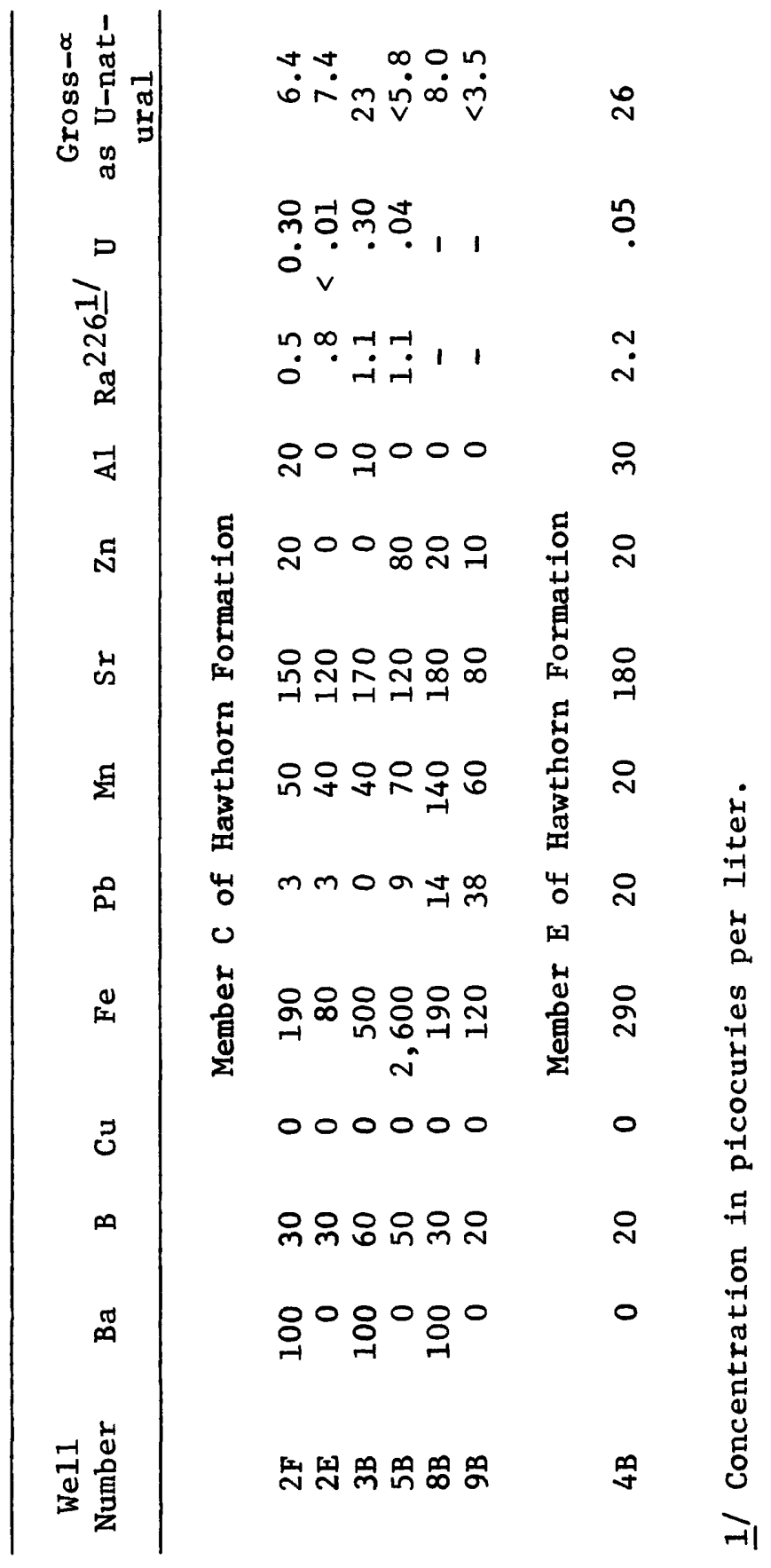


units between the top of the Ocala and the base of the Cedar Keys are more or less permeable, interconnected to varying degrees, and have similar hydrologic properties. Parker and others (1955, p. 188), in naming the Floridan aquifer in south Florida, considered the basal unit of the aquifer to be the Lake City Limestone of middle Eocene age. Stringfield (1936 and 1966) restricted, as did Parker and others, the term Floridan or "principal artesian aquifer" to the freshwater-bearing strata. The 01dsmar Limestone of early Eocene age and the Cedar Keys Limestone of Paleocene age contain saline water nearly everywhere, but Stringfield included the 0ldsmar as part of the Floridan aquifer in places where it contains freshwater. These lower Tertiary limestones are permeable and, as shown by Kohout (1967, p. 350), are, in places, hydrologica1ly interconnected with overlying limestones, at least above the first anhydrite bed of the Cedar Keys Limestone. The fact that the lower Tertiary 1imestones contain saline water nearly everywhere is not herein considered cause for disassociating them from the overlying limestones of generally similar geologic and hydrologic character. The younger limestones, too, contain saline water in some parts of the state.

In the southwestern parts of Columbia and Hamilton Counties and in western Suwannee County, the Floridan aquifer is at or near land surface, and is covered at most only with a thin veneer of sediments which are part of the surficial aquifer. But within the forest, the Floridan is everywhere capped by the Hawthorn confining unit, whose minimum thickness there is about 70 feet (fig. 25).

Lithology of that part of the Floridan that was penetrated by the test drilling varies from a calcarenite to a finely crystalline limestone. Within the calcarenite beds, ground-water storage and movement take place primarily in intergranular pores. In contrast, within the crystalline limestone, fracture and solution cavities provide the principal openings. In lieu of specific information on their hydrogeologic character within the forest, the deeper parts of the Floridan aquifer are assumed to be as described briefly in table 3.

The thickness of the Floridan aquifer beneath the forest is as much as 1,750 feet, based on data from oil test wells near the boundary of the forest. However, the freshwater-bearing part comprises only about 800 to 1,000 feet of the tota1 thickness (Klein, 1975; Meyer, 1962, p. 30 ).

Large diameter wells that tap the Floridan aquifer commonly produce $1,000 \mathrm{gal} / \mathrm{min}$ or more. Yields of a few- to several-thousand gallons per minute are not uncommon.

Ground water within the Floridan aquifer moves generally northeast to east across the forest from a potentiometric high near Lake City (figs. 27 and 28). Water also moves toward Lake City from this potentiometric high. The high probably results from direct recharge of surface water to the Floridan by way of sinkholes that breach the Hawthorn 


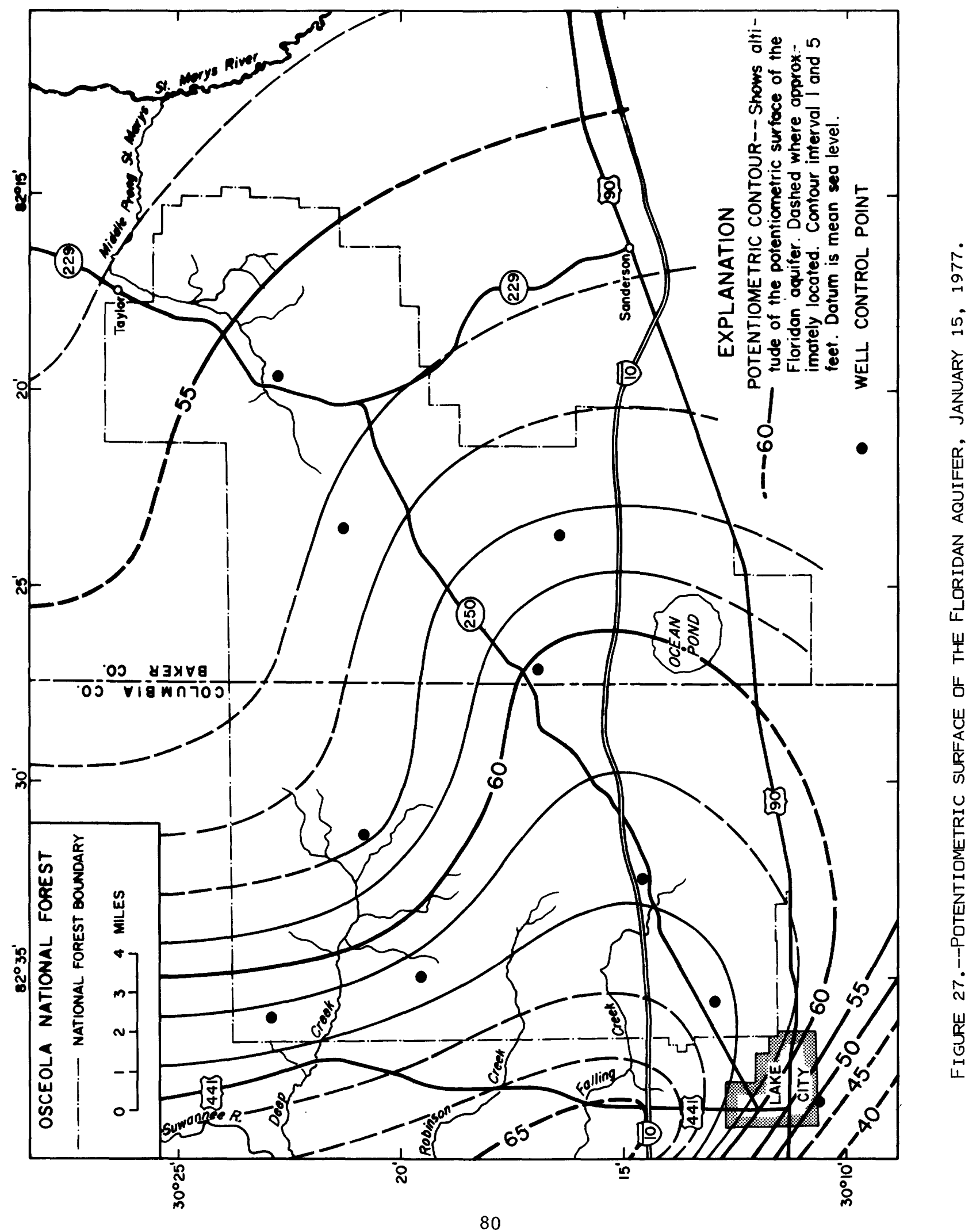




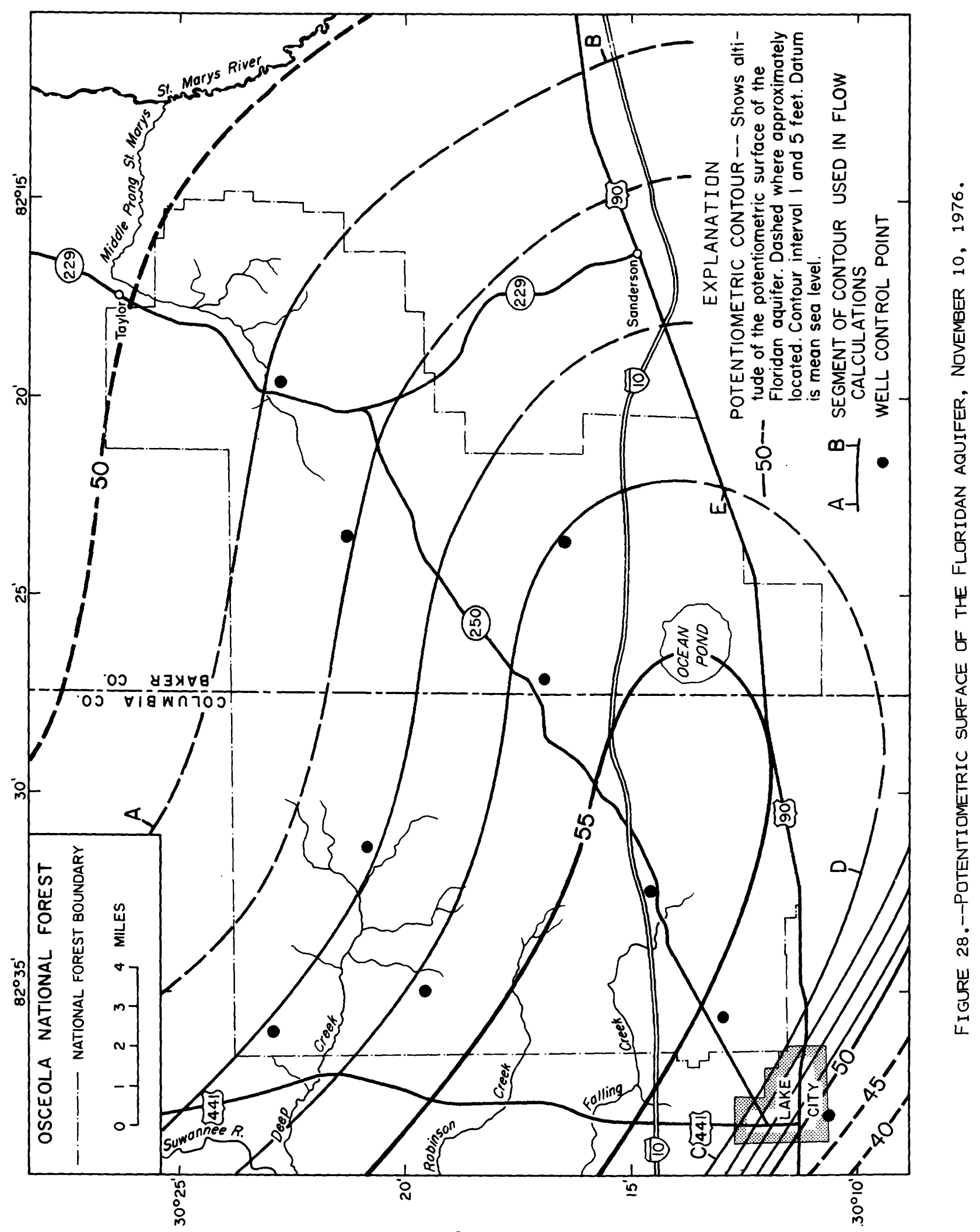


confining unit near the forest. Falling Creek flows into one of these sinkholes about 4 miles west of the forest, creating a point source of recharge to the Floridan there which accounts, at least in part, for the presence of the potentiometric high. Another source of recharge to the Floridan is the downward leakage of water from the surficial aquifer through the Hawthorn confining unit everywhere in the forest. This leakage occurs in response to potential head differences. The Floridan's potentiometric surface is 80 to 90 feet lower than that of the surficial aquifer and about 40 feet lower than that of member $C$ of the Hawthorn. A negligible amount of water, mostly for domestic purposes, is pumped from the Floridan within the forest. The major outflow of water from the Floridan in the forest is by subsurface flow through the aquifer to adjacent areas downgradient of the forest. The comparatively steep slope of the potentiometric surface (figs. 27 and 28) in the Lake City area represents a marked change in the permeability of the Floridan aquifer.

The maximum amount of water leaking through the Hawthorn and recharging the Floridan can be estimated by calculating the amount of water leaving the forest as underflow in the Floridan aquifer. The amount of water flowing through a given area of an aquifer can be calculated by using a potentiometic map if the transmissivity of the aquifer is known. Flow across an open contour can be calculated by using the following form of Darcy's Law (Ferris, 1949, p. 226):

$$
Q=T I L
$$

where: $Q=$ rate of flow perpendicular to potentiometric contour

$T=$ transmissivity, in $\mathrm{ft}^{2} / \mathrm{day}$

$I=$ hydraulic gradient, in feet/mile

$L=$ length of potentiometric contour, in miles.

The uniform spacing of the contours on figure 28 shows that the hydraulic gradient is uniform across practically all of the forest, and averages 0.33 feet per mile to the northeast. A transmissivity of 33,000 $\mathrm{ft}^{2} /$ day was determined for the uppermost part of the Floridan aquifer by the aquifer test described on pages 92 and 93 of this report. The length of segment A-B of the 51-foot contour on figure 28 is 24 miles. Inserting these values in equation (1):

$$
\begin{gathered}
Q=\left(33,000 \mathrm{ft}^{2} / \text { day }\right)(0.33 \mathrm{ft} / \mathrm{mi})(24 \mathrm{mi})=264,000 \mathrm{ft}^{3} / \mathrm{day} \\
\text { or } 6.06 \text { acre-feet per day. }
\end{gathered}
$$

This figure represents the daily amount of water flowing past segment $A-B$ of the 51 foot contour (fig. 28) and discharging to the northeast. Similar calculations for the 8-mile segment $C-D$ and the 9-mile segment D-E of the 54-foot contour (fig. 28) show 3.02 acre-feet per day discharging to the southwest, and 2.24 acre-feet per day discharging to the southeast. The sum of these values represents practically all the water moving out of the forest through the uppermost part of Floridan aquifer. 
Capture of Falling Creek contributes part of the recharge to the Floridan aquifer within the forest. However, an upper limit to the annual leakage rate through the Hawthorn confining unit over the entire forest area can be calculated, if Falling Creek recharge is neglected, as follows:

$$
\begin{aligned}
{ }_{L}^{Q_{L}} & =\frac{(6.06+3.02+2.24 \text { acre-feet } / \text { day })(365 \text { days } / \mathrm{yr})(12 \mathrm{in} / \mathrm{ft})}{156,800 \mathrm{acres}} \\
& =0.31 \text { inches/year or, approximately } 0.3 \text { inches per year. }
\end{aligned}
$$

The potentiometric map on figure 27 strongly reflects the influence of the high stage of the Suwannee River extant at the time. Therefore, leakage calculations based on that potentiometric surface were not made.

Fluctuations of water levels in wells tapping the upper part of the Floridan aquifer are shown on figure 29. Minor water-level fluctuations result from barometric and earth-tide variations; for example, the fluctuations of a few tenths of a foot in well $1 \mathrm{~A}$ during August and September 1976 are the result of barometric highs and lows produced by fronts crossing the area at intervals of 5 to 8 days. Fluctuations caused by earth tides are not discernable at the scale of the graph. Major fluctuations occur in response to seasonal variations in rainfall, evapotranspiration, and in rates of recharge from various sources including Suwannee River. The moderately wet months of June and July, 1976, were followed by a steady decline of Floridan water levels until midNovember, when heavy winter rains produced recharge and water levels rose correspondingly. Recharge from individual local storms is difficult to identify on the hydrographs; rather, water level response seems to reflect more long-term periods of high or low rainfall, resulting in a hydrograph that has only a general resemblance to the rainfall record. Floridan water levels fluctuate more widely than those of the surficial aquifer and the Hawthorn confining unit.

Floridan water levels within the forest are related to the stage of the Suwannee River. Figure 30 compares the stage of the Suwannee River at White Springs, just upstream from the outcrop of the Floridan in the river channel, with the water levels from three Floridan wells in the forest; wells $1 \mathrm{~A}, 3 \mathrm{~A}$, and $6 \mathrm{~A}$ are located progressively farther eastward from the river. The magnitude of ground-water level rise at times of high stream stage decreases progressively eastward away from the river. This figure indicates that the river stage is almost always higher than the ground-water levels in the aquifer in the northern part of the forest. However, near Lake City, to the southeast of the Suwannee River, ground-water levels are higher than river stage over most of the year, suggesting that part of the recharge to the Floridan aquifer due to capture of Falling Creek is discharged to the Suwannee River. At times of high stage in the Suwannee River, such as occurred in December 1976 and January 1977, ground-water discharge from the Floridan aquifer to the river is arrested and the flow is reversed, that is, streamflow 


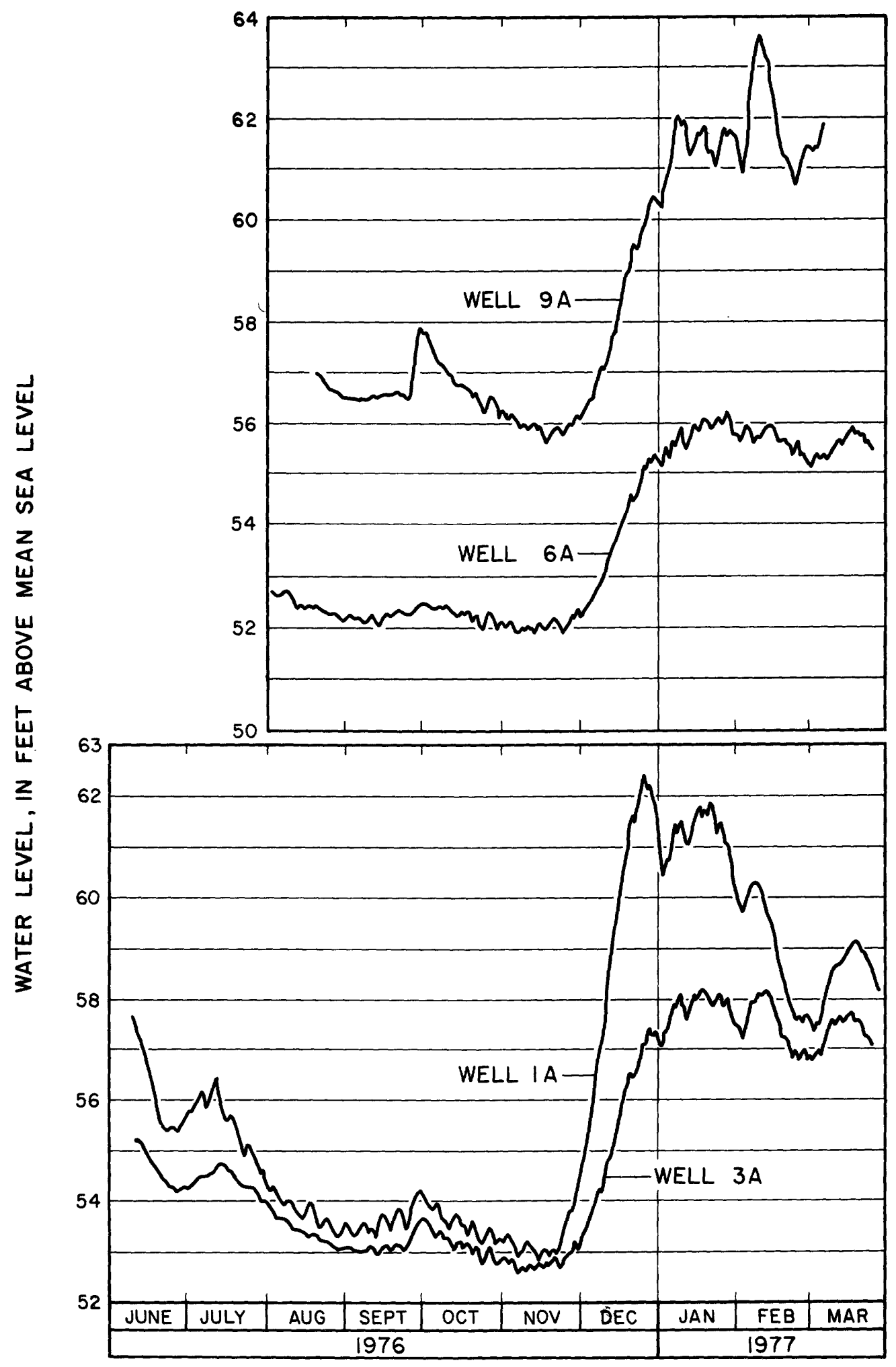

FIGURE 29.--HYDROGRAPHS OF WELLS THAT TAP THE FLDRIDAN AQUIFER. 


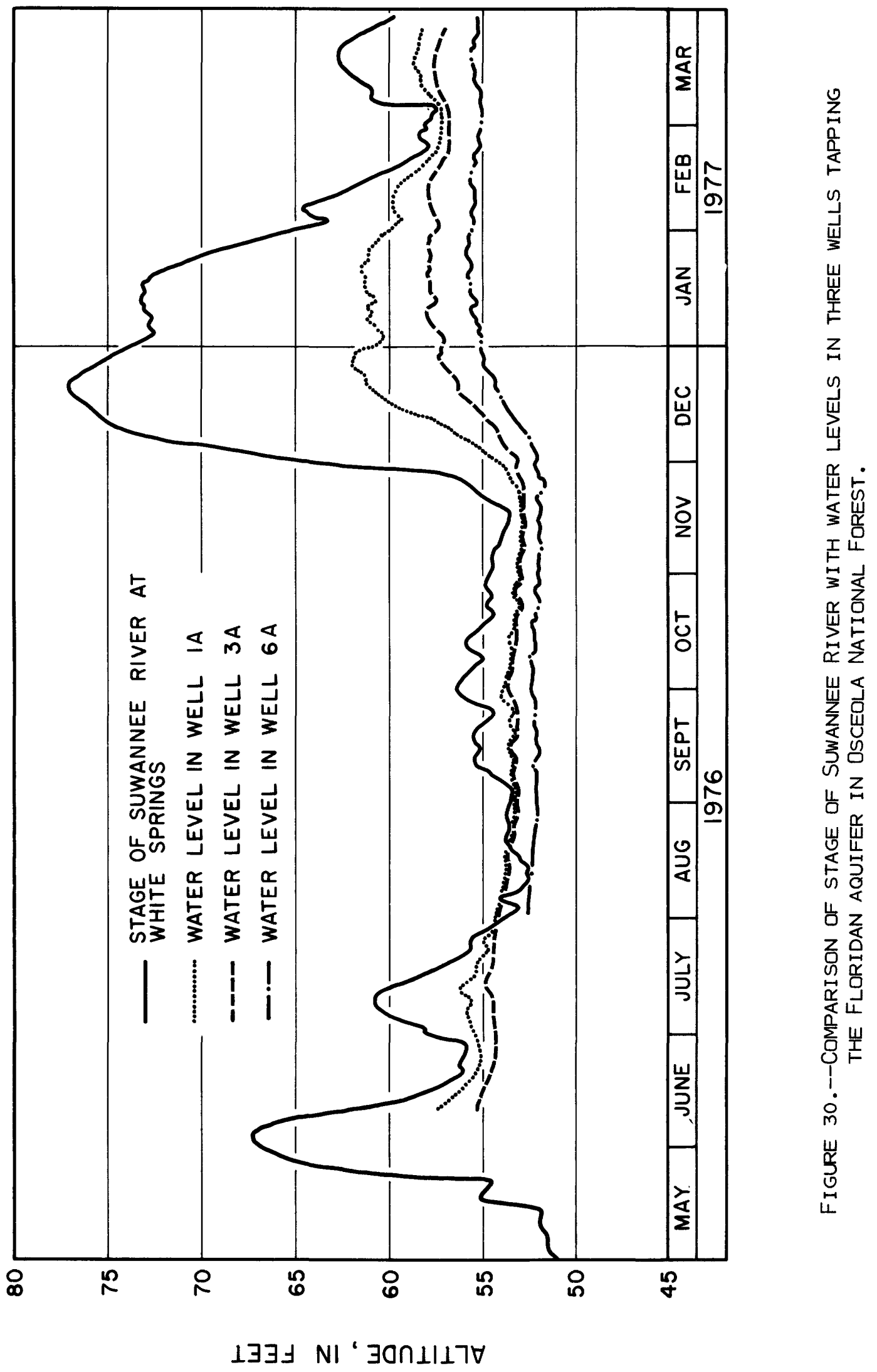


recharges the aquifer. At times of high stage, a ground-water divide may exist somewhere between the western limits of the potentiometric map (fig. 28) and the Suwannee River at White Springs.

Information on the chemical quality of water from the Floridan aquifer is avallable only from the uppermost part of the aquifer within Osceola National Forest. Test wells sampled penetrated 22 to 49 feet into the Floridan. Thus, wells penetrating considerably greater thicknesses of the aquifer could produce water of different quality than that reported in tables 15 and 16. The lower part of the Floridan probably contains slightly saline water of the sodium choride type, and perhaps above it, slightly saline water of the calcium sulfate type. Although the existence of calcium sulfate water in the Floridan aquifer has been reported (see, for example, Meyer, 1962, p. 47), this type water has not been encountered in the forest.

The chemical character of water in the uppermost Floridan is fairly uniform within the forest. Specific conductance ranges from 361 to 508 umhos/cm, dissolved solids from 232 to $329 \mathrm{mg} / \mathrm{L}$, and $\mathrm{pH}$ from 7.2 to 7.8. The water is of the "calcium magnesium bicarbonate" type, similar to that in the Hawthorn confining unit. Concentrations of fluoride range from, 0.2 to $0.6 \mathrm{mg} / \mathrm{L}$, total phosphorous (as P) is 1ess than $0.05 \mathrm{mg} / \mathrm{L}$ in concentration, total nitrogen (as $\mathrm{N}$ ) ranges from 0.01 to $0.36 \mathrm{mg} / \mathrm{L}$, and $\mathrm{Ra}^{226}$ ranges from 0.6 to $5.2 \mathrm{pCi} / \mathrm{L}$ in concentration. Strontium, iron, and barium are the most abundant trace elements, in that order.

The Floridan aquifer within the forest is part of a larger regional flow system that encompasses vastly more area than does the forest. For this reason, the quality of Floridan aquifer water within the forest is a result of the mixing of water flowing into the area from upgradient sources with water leaking into the Floridan from overlying strata. Water entering the Floridan in the forest through vertical leakage from the Hawthorn is generally similar but slightly more mineralized than that moving through the aquifer laterally from adjacent upgradient areas. Therefore, leakance probably does not greatly affect the character of the Floridan's water quality. Except for those parts of the Floridan that are in areas where the aquifer is recharged directly by surface inflow, such as Falling Creek and along the Suwannee River downstream from White Springs (J. E. Dysart, vritten commun., 1977), the chemical quality of water in the Floridan is fairly consistent with time and over large areas. Exceptions occur where deposits of gypsum and(or) anhydrite locally enrich the circulating ground water with calcium and sulfate, or where deeper saline waters move upward in response to changes in freshwater head and mix with the fresh water. 


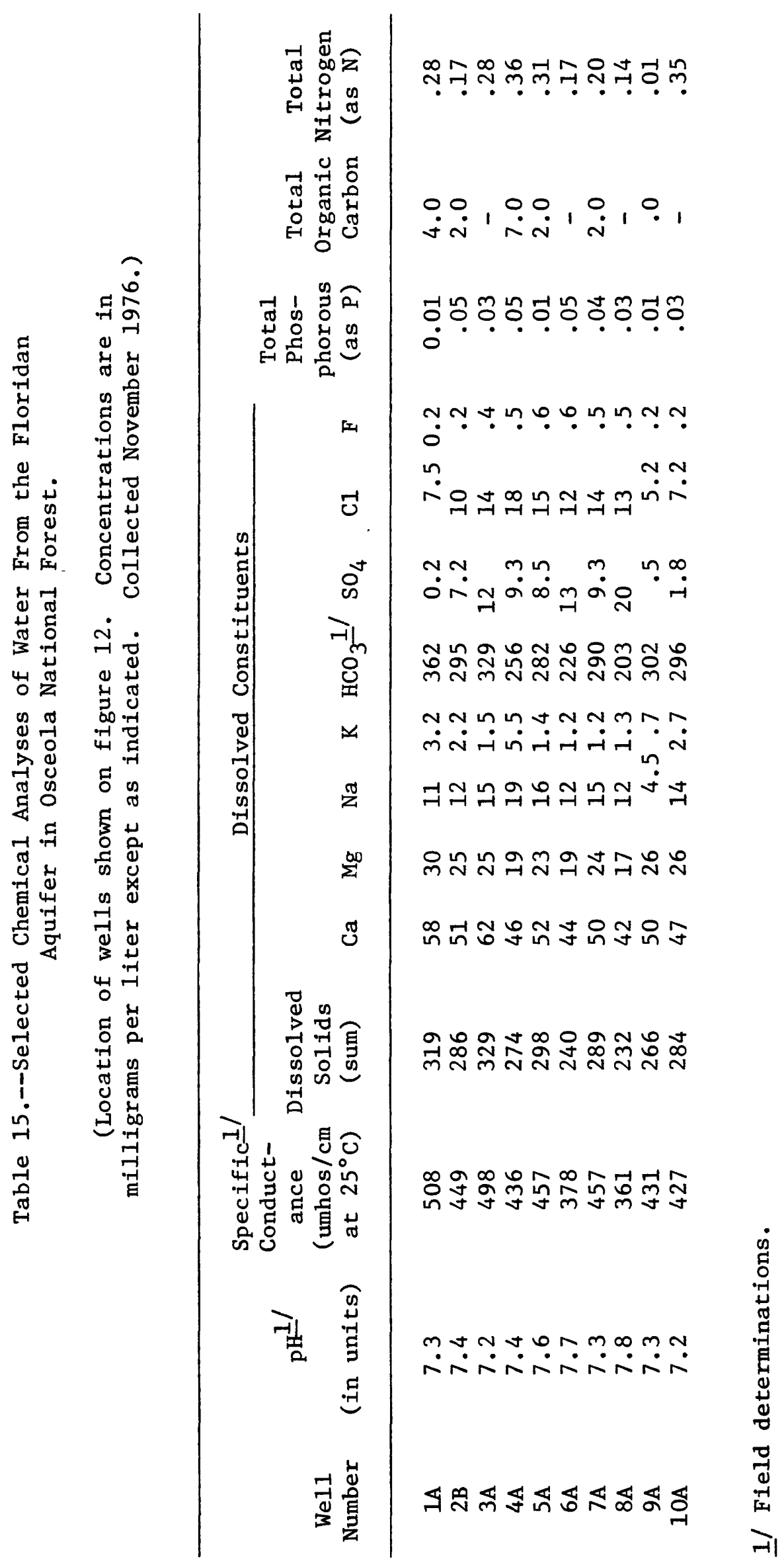




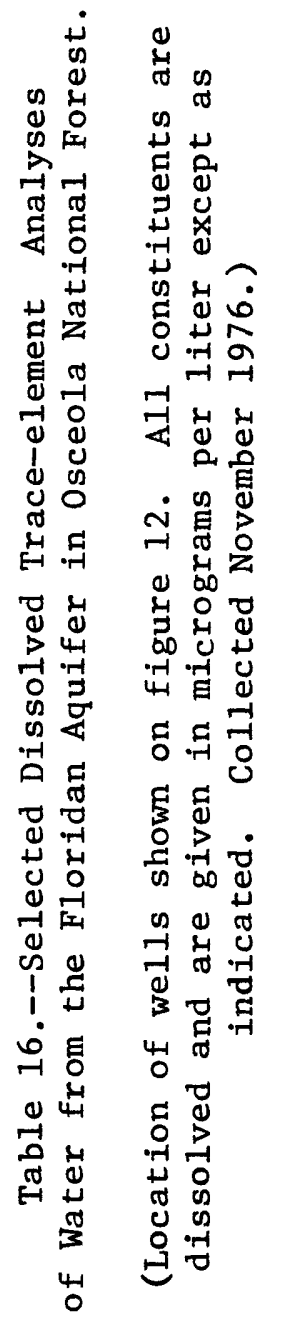

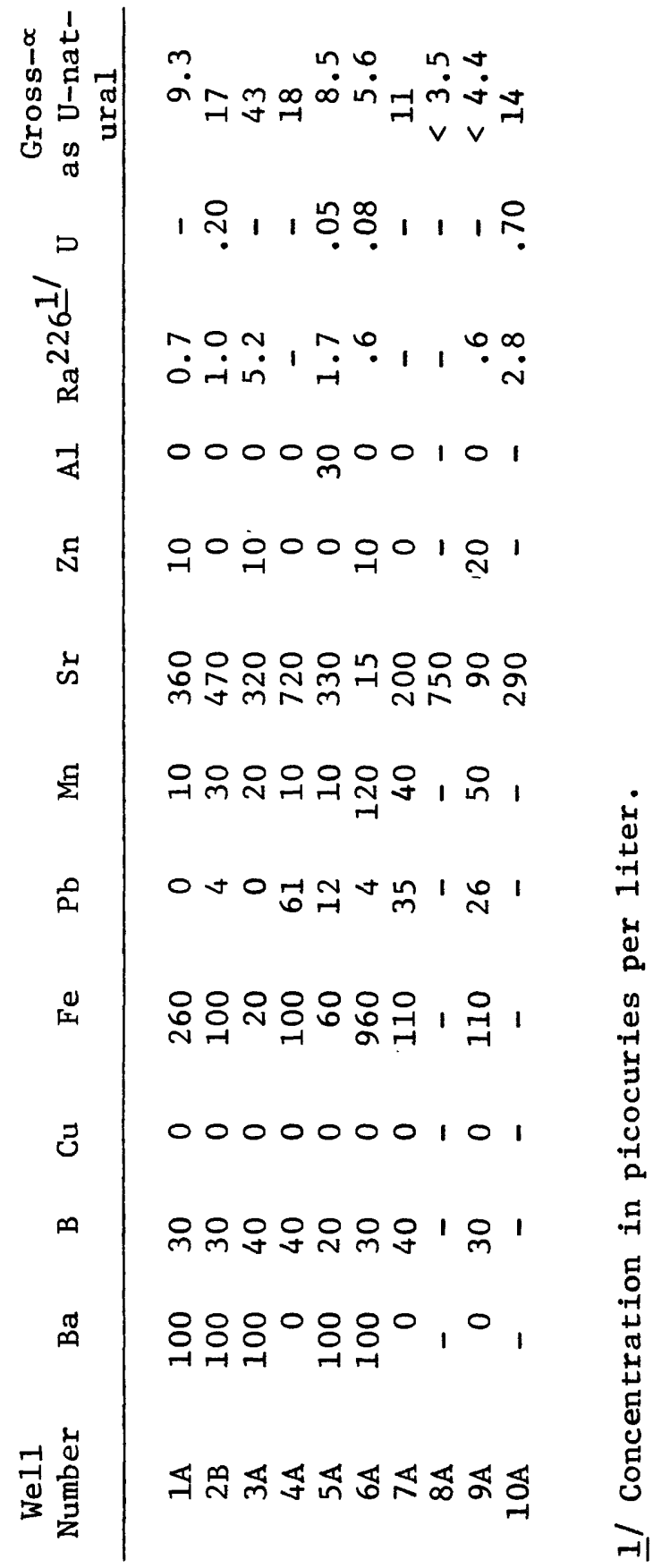


Two aquifer tests were conducted at site 2 (fig. 12) to determine the hydraulic properties of the hydrogeologic units underlying Osceola National Forest. Selection of site 2 for the aquifer tests was based on 1ithologic information obtained from test drilling. The Hawthorn confining unit appeared more permeable at site 2 than elsewhere in the fores Therefore, the potential for vertical leakage into the Floridan aquifer of water that might be contaminated by phosphate industry operations was considered greater than at any other site test-drilled within phosphate lease application areas.

The Floridan aquifer was pumped during the first of these aquifer tests and the Hawthorn $\mathrm{C}$ member during the second. During the tests, water-level changes were recorded in the surficial aquifer, the Floridan aquifer, and in several zones within the Hawthorn confining unit. Compaction measurements were also made at several levels within the Hawthorn confining unit. The well network and instrumentation used for the test, the methods of analysis of the test data, and the results of these analyses are discussed below.

\section{We11 Locations and Instrumentation}

The locations of the pumped we11s, observation wells, and extensometer installations are shown on figure 31. The depth and type of completion of the wells and extensometers are listed in table 5 and are shown on figure 32. This figure also shows the general geologic conditions at the test site and the static water levels within each litholog unit.

The wells shown as open circles on figure 31 were equipped with float-type water-level recorders. All other observation wells were equipped with electrical pressure transducers housed in inflatable packers. Pressure changes produced by pumping or by natural fluctuations of water levels were transmitted from the transducers as voltage variations. These variations were recorded on computer-compatible magnetic tape and simultaneously displayed on chart-type recorders. Compaction and expansion of beds within the Hawthorn confining unit were measured by three free-standing pipe extensometers. Extensometer data and water levels in the pumping wells were continuously recorded in the same fashion as transducer data. Barometric pressure fluctuations and precipitation were also recorded continuously.

\section{Methods of Analysis and Test Results}

The data collected during the two aquifer tests were analyzed by methods based on analytical models of leaky aquifer systems. Two types of models were used in the analyses: (1) Radial flow models (Jacob, 1946; Hantush and Jacob, 1955; Hantush, 1956, 1960; Neuman and Witherspoo 1971) and (2) Vertical flow models (Wolff, 1970; Wolff and Papadopulos, 


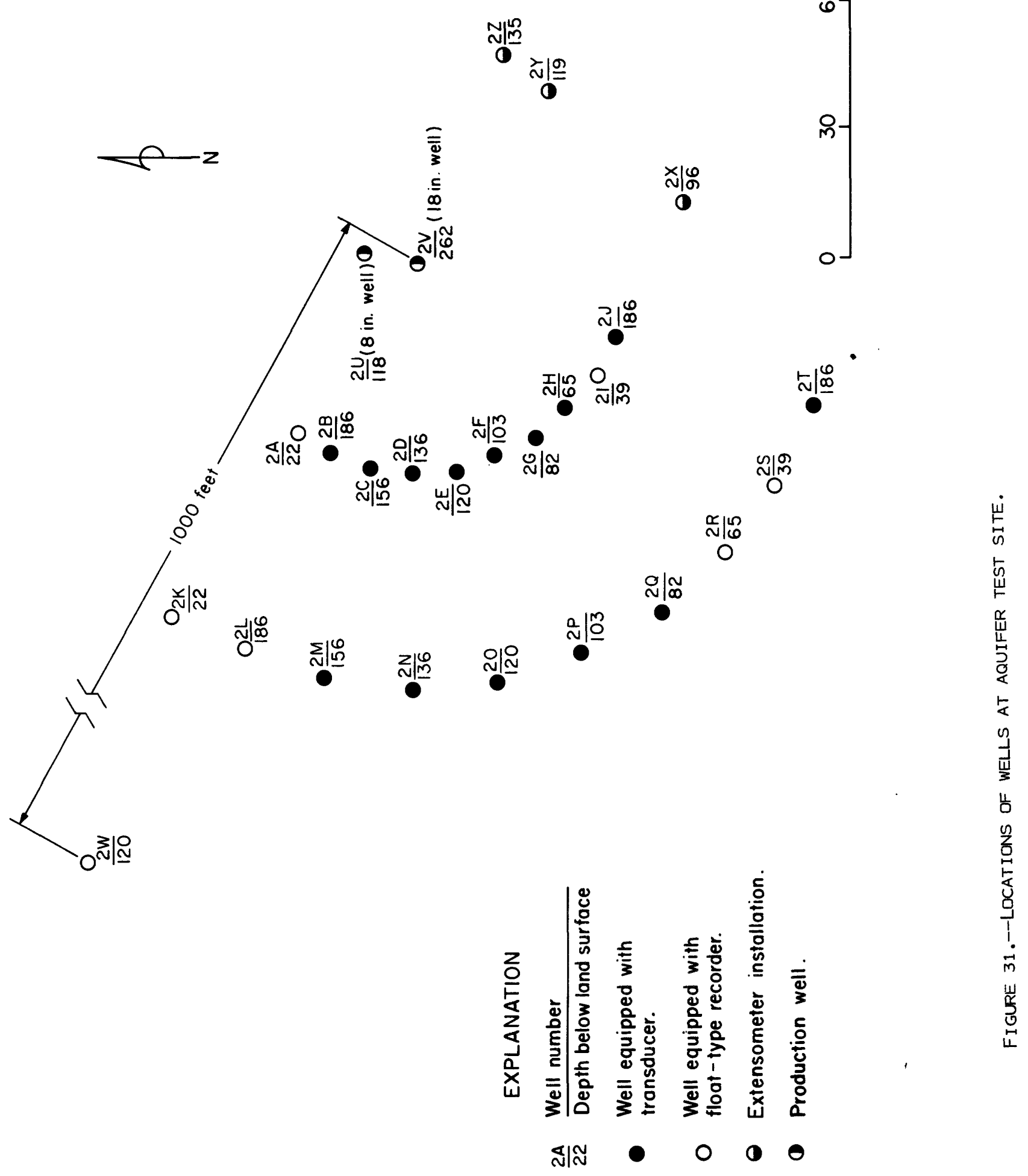




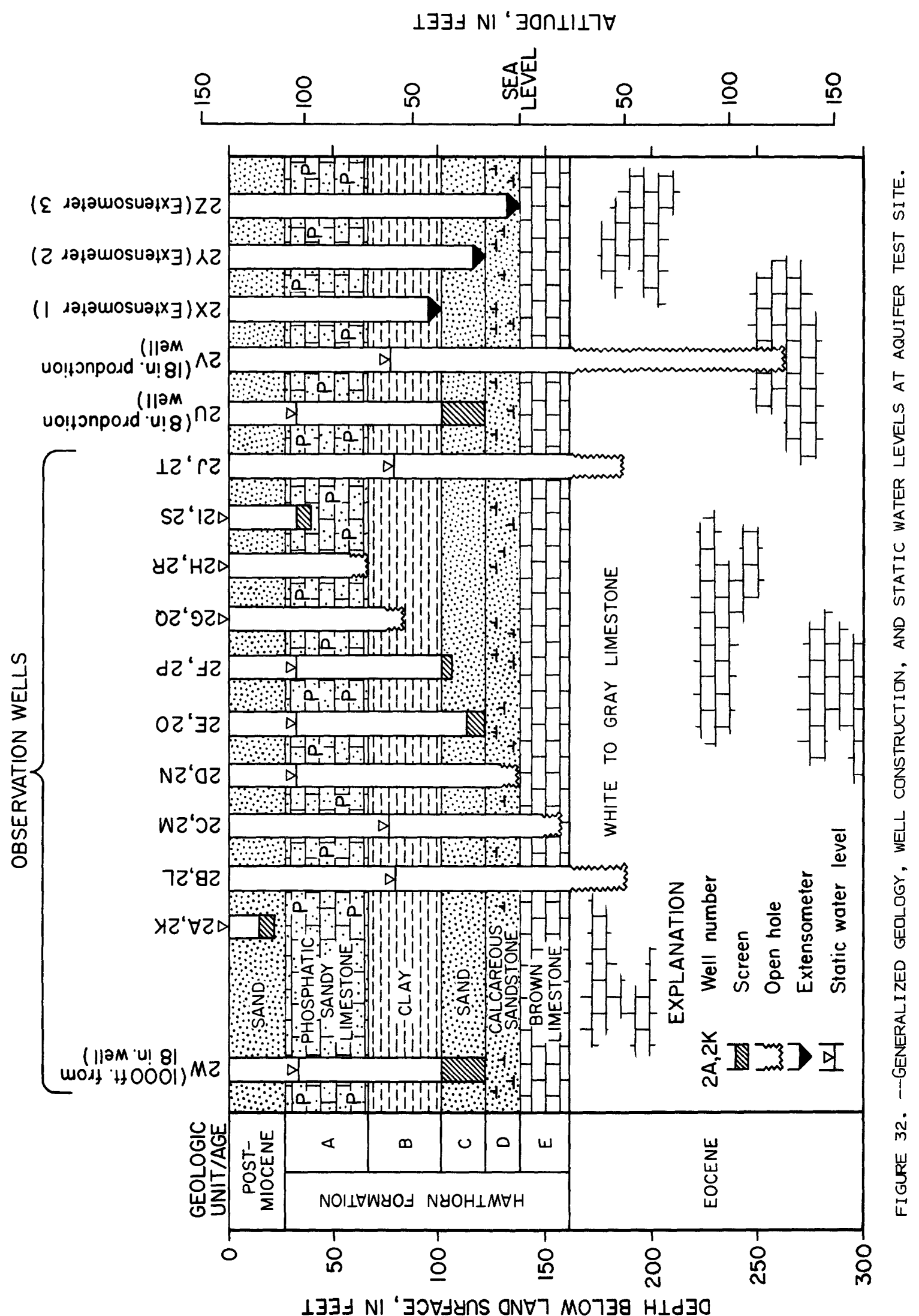


1972). Methods based on radial flow models generally permit the determination of the hydraulic properties of both the pumped aquifer and the confining beds. In layered systems, such as the one at the test site, confining bed properties determined by these methods represent average values that reflect the combined effect of all the layers through or from which leakage occurs. Determinations based on vertical flow models are limited to the hydraulic properties of the confining beds, and with proper placement of piezometers, they permit the evaluation of individual layers within the confining beds.

The well network used for the aquifer tests (see fig. 31) was specifically designed to provide data for analyses by both radial and vertical flow models and to allow the determination of the hydraulic properties of the individual members of the Hawthorn confining unit, as initially identified on the basis of lithologic data.

Floridan Test: The Floridan aquifer test was conducted by pumping well $2 \mathrm{~V}$ at a rate of $1,320 \mathrm{gal} / \mathrm{min}$. Within minutes after the beginning of the test, the drawdowns in the pumped well and in the nearby observation we11s open to the Floridan aquifer (we11s $2 \mathrm{~B}, 2 \mathrm{~L}, 2 \mathrm{~J}$, and $2 \mathrm{~T}$ ) reached a near steady state. After one day steady-state conditions were also reached in the observation wells open to the $\mathrm{E}$ and $\mathrm{D}$ members of the Hawthorn confining unit (we1ls 2C, 2M, 2D, and 2N). Pump failure caused the drawdown phase of the test to terminate after 45 and one-half hours. Water-level data were collected during five days of recovery.

The data from the Floridan test indicated that the upper part of the $E$ member of the Hawthorn confining unit is less permeable than the lower part of the $\mathrm{E}$ member; therefore, downward leakage from the $\mathrm{C}$ member (the most permeable member of the Hawthorn confining unit) to the Floridan aquifer is controlled by the upper part of the $E$ member. The exact location of the boundary between the upper and lower parts of the $E$ member could not be defined, but it lies in the interval between the top of the $\mathrm{E}$ member and the top of the open part of wells $2 \mathrm{C}$ and $2 \mathrm{M}$.

The hydraulic properties obtained from the analyses of test data are as follows:

Floridan aquifer

Transmissivity: $\quad 33,000 \mathrm{ft}^{2} / \mathrm{d}$

Storage coefficient: $\quad 0.00007$

Leakance:

$0.00069 \mathrm{day}^{-1}$

Hawthorn confining unit

Ratio of vertical hydraulic conductivity

$D$ member to upper $E$ member: 7

Vertical hydraulic diffusivities

Upper $\mathrm{E}$ member:

Lower $\mathrm{E}$ member:

$360 \mathrm{ft}^{2} / \mathrm{d}$

$5,600 \mathrm{ft}^{2} / \mathrm{d}$ 
The storage coefficient and hydraulic diffusivity are parameters that are determined from transient portions of test data. Because of the quick stabilization of the drawdowns during this test the calculated values of the storage coefficient and of the hydraulic diffusivities may depart some from the actual values. Further evaluation of the hydraulic properties of the Floridan aquifer are made in a later section.

Hawthorn Test: The Hawthorn test was conducted by pumping we11 $2 U$, screened in the $C$ member of the Hawthorn confining unit (fig. 32) at a rate of $3.2 \mathrm{gal} / \mathrm{min}$ for 336 hours (14 days); recovery of the system was recorded for another 363 hours (15.1 days). The effects of pumping were felt in wells screened in the $C$ member and those open to the base of the underlying $D$ member. A slight effect may have been felt in the wells open to the lower part of the $\mathrm{E}$ member, but this could not be definitely established because of problems that developed with the annular seal in well $2 \mathrm{C}$ and with the pressure transducer in we11 $2 \mathrm{M}$. However, despite the length of the test the effects of pumping were not felt in wells open to the overlying members and, therefore, determination of their hydraulic properties was not possible. Furthermore, wells 2G and $2 Q$ open to the middle of the $B$ member of the Hawthorn reflected all the fluctuations that occurred in the surficial aquifer. These observations led to the conclusion that, barring unknown well construction problems such as possible leakage through the annuli of both wells, the B member, like the $\mathrm{E}$ member, consists of two parts: (1) an upper part that is hydraulically well connected to the surficial aquifer, and (2) a tight lower part that controls leakage from the overlying units to the $C$ member of the Hawthorn. Again, the exact location of the boundary between the two parts is not known, but it lies in the interval between the top of the $C$ member and the bottom of we11s $2 G$ and $2 Q$.

Analysis of the data from the wells screened in the $C$ member by the Hantush (1960) method resulted in the following properties for the $C$ member:

$$
\begin{array}{ll}
\text { Transmissivity: } & 15 \mathrm{ft}^{2} / \mathrm{d} \\
\text { Storage coefficient: } & 0.00012 \\
\text { Hydraulic conductivity: } & 0.75 \mathrm{ft} / \mathrm{d}
\end{array}
$$

The proximity of the observation wells to the pumped well and to each other did not permit a reliable determination of the leakage properties by this method.

Analysis of the data from the underlying members by the verticalflow method (Wolff and Papadopulos, 1976) yielded results that conflicted with the results obtained from the Floridan test. For example, the ratio of the vertical hydraulic conductivity of the $D$ member to that of the upper part of the $E$ member determined from this analysis was 2.3 instead of 7 as determined from the Floridan test data. This conflicting result, the sandy character of the $D$ member, and its higher hydraulic conductivity indicated by both analyses, led to the conclusion 
that, during the Hawthorn test radial flow occurred within the $D$ member. Hence, the vertical flow method would not be applicable. Therefore, the results of this vertical-flow model analysis were disregarded.

Laboratory and Extensometer Results

In addition to the analyses of the aquifer test data, hydraulic properties were also determined by laboratory tests of core samples obtained during the drilling of well $2 \mathrm{~V}$, and from analyses of the extensometer data according to the methods developed by Riley (1970). The results obtained by these tests and analyses are presented on table 17 .

\section{Evaluation of Floridan Aquifer Test Results}

The well pumped for the Floridan aquifer test penetrated and was open to only the upper 102 feet of the Floridan, or 10 to 12 percent of the freshwater-bearing thickness of the aquifer. Because of the shallow well penetration and the vertical inhomogeneity of the Floridan, the transmissivity determined from this test, 33,000 $\mathrm{ft}^{2} / \mathrm{d}$, is probably low. Studies by Bentley (1977) and by Pride and others (1966), indicate that the apparent transmissivities determined from aquifer tests of the Floridan vary directly with the thickness penetrated. These studies indicated that within a range of 100- to 500-ft. thickness of aquifer penetrated and tested the apparent transmissivities computed varied in roughly a 1:1 ratio, or greater, with the thicknesses of aquifer penetrated. Moreover, the specific capacities of four wells penetrating 500 to $600 \mathrm{ft}$. of aquifer thickness in nearby Hamilton County were reported to range roughly two to five times that of the well test- pumped at site 2 in Osceola National Forest. Therefore, for purposes of computing drawdowns in the section of this report that deals with the impact of potential phosphate mining in the forest, the actual transmissivity of the Floridan aquifer in the forest is estimated conservatively to be $66,000 \mathrm{ft}^{2} / \mathrm{d}$, but it could be even greater. Such a value would be in accord with that predicted from Bentley's data (1977, fig. 27) for the Floridan aquifer in northeast Florida.

The storage coefficient determined from the test is only a rough estimate of the actual value. The value of $7 \times 10^{-5}$ is near the low end of the range of storage coefficients of most confined aquifers (Lohman, 1972, p. 8), particularly if one considers the Floridan aquifer to have a thickness on the order of 1,000 feet or more. The estimate of the storage coefficient, too, is probably low, perhaps by a factor of two, and reflects the shallow penetration of the aquifer by the test well. However, as a more accurate estimate of the storage coefficient is not required for this investigation, adjustments to the test value were not at tempted. 


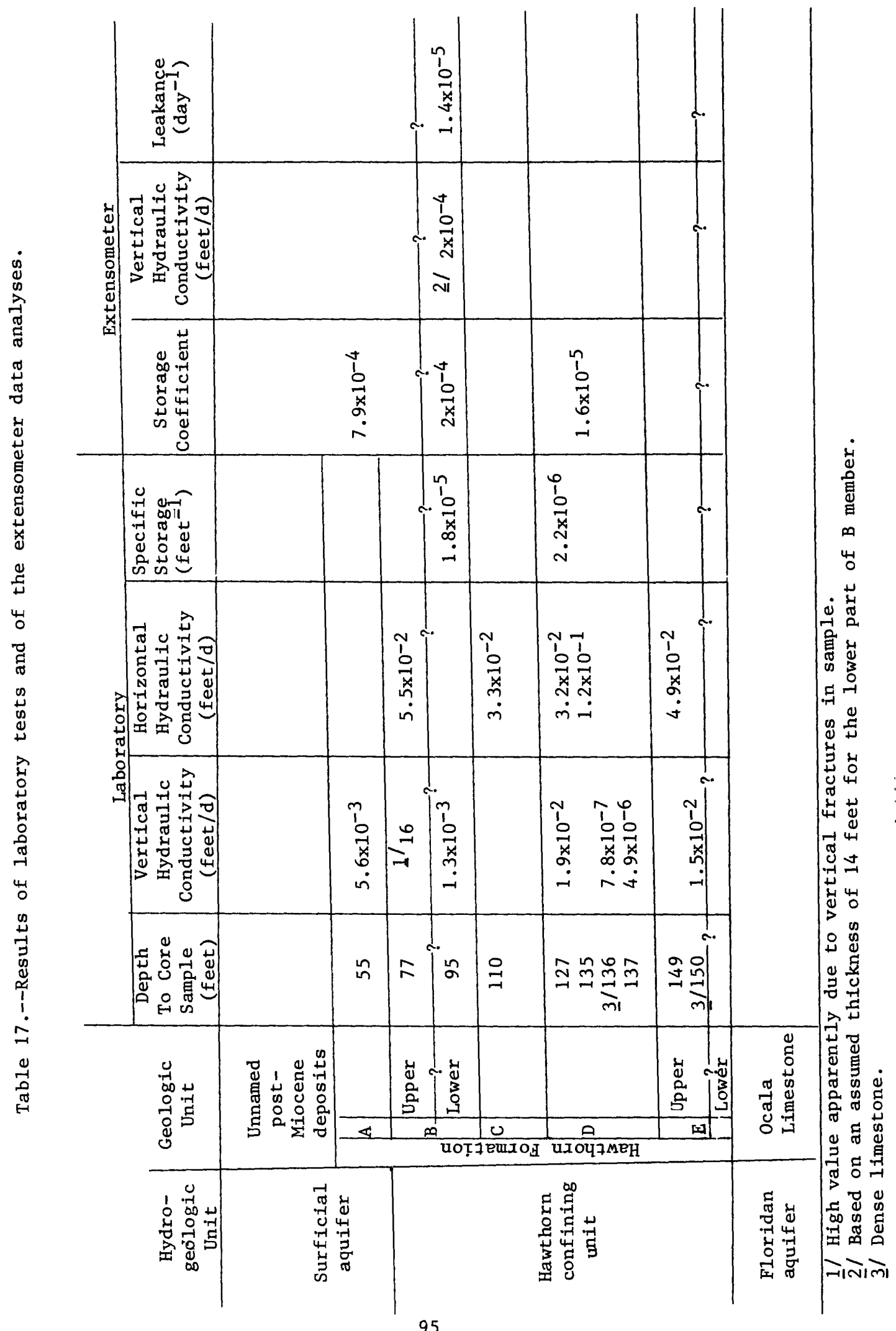


On the other hand, the leakance value determined is much too high, if one considers the leakance to apply only to the overlying confining beds. Taking members $D$ and $E$ of the Hawthorn Formation as representing the confinement reflected by the determined leakance of $6.9 \times 10^{-4} \mathrm{day}^{-1}$, and applying the prevailing natural vertical hydraulic gradient of about 1 , the rate of downward leakage to the Floridan aquifer would be about $10 \mathrm{ft} / \mathrm{yr}$. Obviously such a value is unrealistically high as rainfall in this area averages only about $4.5 \mathrm{ft} / \mathrm{yr}$ and virtually all of the rainfall can be accounted for by evapotranspiration and streamflow (see later section on water budget). The leakance as determined from the aquifer test is thought to reflect upward leakage from lower beds of the Floridan aquifer because of the shallow penetration of the aquifer by the test we11.

\section{Water Budget}

A water-budget analysis evaluates the quantities of water that enter and leave an area during a given time period, and equates their net sum to the change in the quantity of water stored in the area during that period. Because of Florida's ample rainfall, the quantities of water entering and leaving an area in Florida usually are large in relation to the change in the quantity of water stored in the area, especially if the time period involved spans several years. Consequently, when long-term average annual values of the various water-budget items are used, the change in storage can be disregarded without significant error. Thus, for the long term, the water budget of an area in Florida can be established by equating the water that enters the area to that which leaves the area. This relationship for Osceola National Forest can be expressed by the equation:

where

$$
P+S W I+G W I=E T+S W O+G W O
$$

$P=$ precipitation

$S W I=$ surface-water inflow

$G W I=$ ground-water inflow

$E T=$ evapotranspiration

$S W O=$ surface-water outflow

GWO = ground-water outflow

The major purpose of this water-budget analysis is to provide a second determination of the amount of water that may move downward to the Floridan aquifer underlying Osceola National Forest. Towards this end the regional flow of water through the Floridan aquifer can be disregarded. Similarly, the ingress and egress of water by subsurface flow through the surficial aquifer can be disregarded because of the minimal quantities involved and because over a period of a year they are virtua1ly equal. Some surface water enters Osceola National Forest through Deep Creek and Middle Prong St. Marys River whose drainage 
basins extend beyond the northern boundary of the forest. However, this has no bearing on the water-budget analysis insofar as the surface-water runoff for the basin is computed on a unit-area basis and applied uniformly over the entire basin in the absence of runoff data for subareas. Thus, for the purpose of this analysis, the water entering Osceola National Forest is considered to consist only of rainfall (P) on the forest, and water leaving the forest is considered to consist only of evapotranspiration $(E T)$, surface-water runoff (SWO), and leakage to the Floridan aquifer (GWO). The water-budget equation thus reduces to:

$$
P=E T+S W O+G W O
$$

Leakage to the Floridan aquifer can be determined as a residual of the other terms of the water-budget equation arranged as follows:

$$
G W O=P-E T-S W O
$$

Because the runoff from an area varies with rainfall, the estimates of rainfall and runoff used in a water-budget analysis should be of the same time period. The average annual runoff from Osceola National Forest has been related to the average annual discharge of the St. Marys River at Macclenny for the period 1927-75. Rainfall at Lake City averaged about 53 inches per year during 1927-75. Lake City rainfall probably is more representative of that on the forest than is the rainfall at other stations in the general area. Moreover, the estimate of rainfall on the forest differs only slightly if data from other available stations are considered along with the data for Lake City. For example, other rainfall stations near Osceola National Forest are Glen St. Mary, about 10 miles east; Folkston 9SW, about 23 miles northeast; and Jasper, about 22 miles northwest (fig. 1). The record of rainfall at each of these stations is complete since at least 1952, the Jasper station having the shortest record of the three. During 1952-75 the annual rainfall averaged about 52 inches at Folkston 9SW, 54 inches at Lake City, 56 inches at Jasper, and 58 inches at Glen St. Mary. The average rainfall at the four stations was about 55 inches, or 1 inch more than the average annual rainfall at Lake City during the same period. By using the Thiessen polygon method to estimate rainfall on the forest by considering all four stations, the data for the Jasper and Folkston 9SW stations would not be given any weight because these stations are so far from the forest. Data for the Glen St. Mary station would apply to the eastern one-third of the forest, and the Lake City data would apply to the western two-thirds. The average annual rainfall at Glen St. Marys is about 4 inches greater than that of Lake City. Hence, the use of the Thiessen polygon method results in an estimate of rainfall on the forest of 54 inches or one inch greater than that obtained by the use of the Lake City station alone. Thus, the average annual rainfall on the forest for the period $1927-75$ is estimated to be 53 to 54 inches. 
The average annual runoff from the forest was previously estimated at about 13 inches. This estimate is subject to error insofar as it is based in part on the flow of Deep Creek and Robinson Creek which were gaged for a relatively short time. The estimate of average annual runoff from Middle Prong St. Marys River (about 11 inches) is more reliable because this stream was gaged for 12 years, and, further, because its discharge correlates well with that of the St. Marys River near Macclenny which has been measured since 1926. The runoff per unit area was appreciably larger for Deep Creek and Robinson Creek than for Middle Prong St. Marys River during the investigation, the only time that these streams were measured concurrently. Although this relation might not hold at other times, it provides a basis for assuming that the average annual runoff of the Middle Prong St. Marys River represents the minimum value that should be assigned to runoff from the forest overall. Consequently, for the purposes of this water-budget analysis, the average annual runoff from the forest is estimated to be 11 to 13 inches.

Both the average annual rainfall and the average annual runoff vary considerably with the time period selected for their evaluation, but the choice of the time period is not of critical importance to this water-budget analysis. For example, for the 30-year periods 1931-60, 1936-65, and 1941-70, the average annual rainfall at Lake City was about 51, 53, and 54 inches, respectively. During these same three periods, the average annual runoff of the St. Marys River near Macclenny was about 12, 13 and 14 inches, respectively. The variation in average annual runoff from the forest during these same periods probably was about the same as that shown for the St. Marys River near Macclenny. Inasmuch as these items appear with opposite signs in the water-budget equation, the overall balance is fairly well maintained regardless of the time period selected. However, the time period must be long enough to minimize the error caused by disregarding the change in storage.

In regard to evapotranspiration, a large part of Osceola National Forest is swampy, and even in non-swampy parts of the forest the water table is at or near the land surface for a considerable time each year. The vegetative cover is relatively dense over most of the area. Given these conditions and the estimates of evapotranspiration available for other parts of Florida, the evapotranspiration from the forest is estimated to be 39 to 40 inches or more per year.

If the various estimates of rainfall, runoff, and evapotranspiration are combined in the water-budget equation (equation 5), the general magnitude of the ground-water outflow from the surficial aquifer to the Floridan can be determined as a residua1. For example, when the maximum estimated value of average annual rainfall (54 inches) is combined with the minimum estimated values of average annual runoff ( 11 inches) and evapotranspiration (39 inches), the indicated ground-water seepage to the Floridan from the forest, 4 inches, represents the maximum possible annual value. Similarly, when the minimum estimated value of average annual rainfall (53 inches) is combined with the maximum estimated 
values of average annual runoff (13 inches) and evapotranspiration (40 inches or more), the indicated ground-water seepage from the forest, zero, represents the minimum possible value. Obviously, the average annual rainfall would have to exceed 53 inches or the average annual runoff would have to be less than 13 inches to accomodate more than 40 inches of evapotranspiration. However, the maximum value of evapotranspiration that could reasonably be assigned to the forest is about 42 inches. The probable ranges given for the average annual rainfall and runoff will readily accomodate this amount of evaoptranspiration. In summary, the probable limits of the water-budget equation for Osceola National Forest can be expressed, in inches, from equation 5:

$$
G_{(0-4)}=P_{(53-54)}-E T(39-40+)+S W O(11-13)
$$

The lower end of the range for ground-water outflow as determined by this water-budget analysis is in accord with the outflow estimate made earlier, based on ground-water flow calculations.

\section{HYDROLOGIC EFFECTS OF PHOSPHATE INDUSTRY OPERATIONS IN HAMILTON COUNTY}

\section{Current Phosphate Industry Operations}

Most of this section (p. 99 -123) was prepared from information supplied by personnel of Occidental Chemical Company, White Springs, Florida, or was extracted from an Occidental Chemical Company publication. Other sources of information are noted specifically.

\section{Mining and Beneficiation}

Mining of phosphate ore began in Hamilton County in 1965 in the eastern section of the drainage basin of Swift Creek (fig. 33). Extraction of these deposits has progressed over the past 12 years into parts of Hunter Creek and Roaring Creek basins. To date (1977), several square miles of surface area have been involved in the mining activities which are scheduled to continue for many years to come. The Suwannee River mining area has been continuously mined since 1965. Operations began in the Swift Creek mining area in 1975 and were suspended there on January 1 , 1977. Mining and beneficiation are associated with both operations. Beneficiation and chemical processing presently is being done only at the Suwannee River mining area. A chemical plant addition is planned in the Swift Creek mining area.

Land is cleared by bulldozer and drained in preparation for openpit extraction by wet, surface-pit mining techniques. Electric-powered walking draglines with 30 to 45 cubic yard capacities are capable of removing about 1,000 cubic yards of phosphate matrix per hour each. Work usually continues 24 hours a day except during maintenance or other 


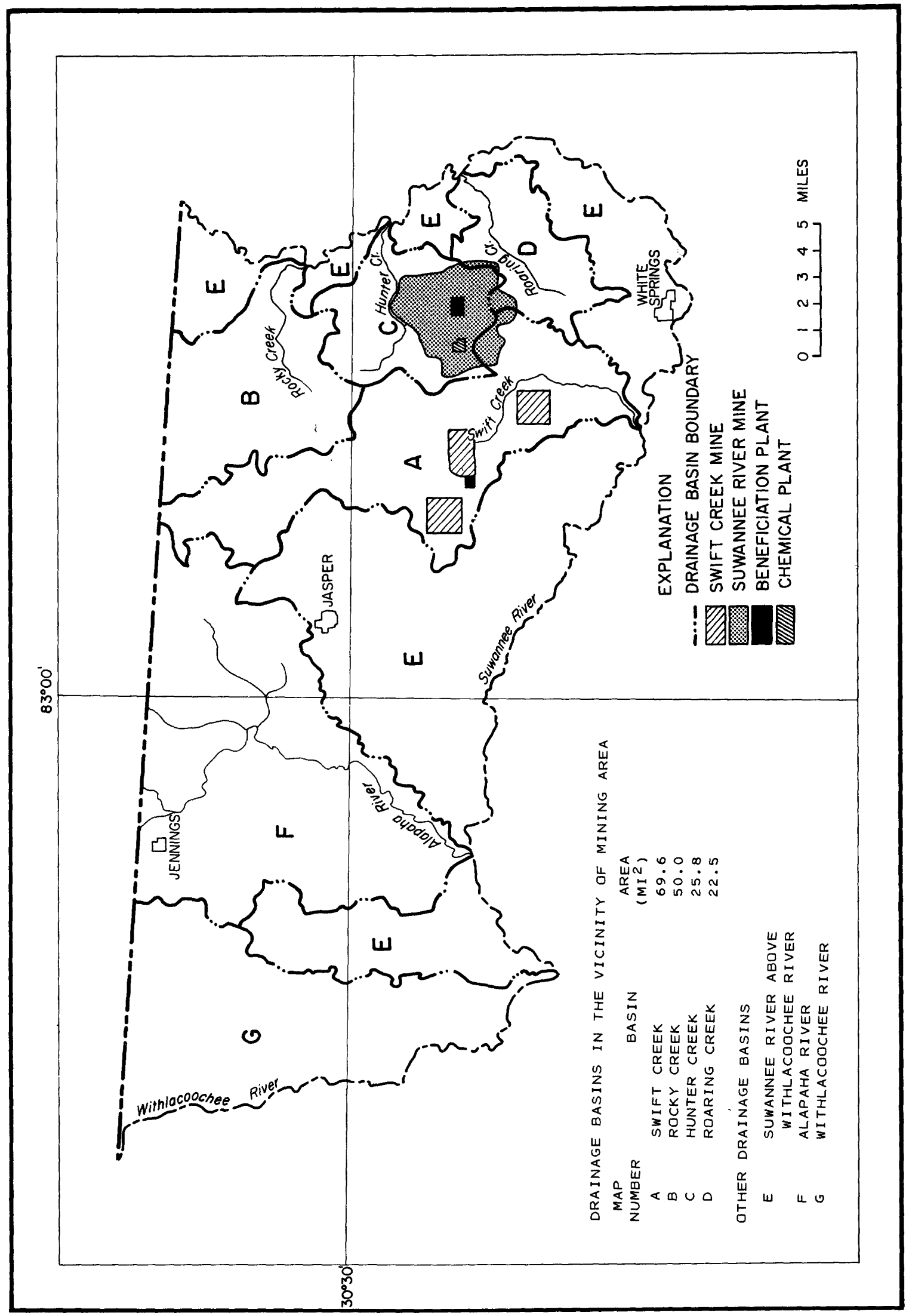

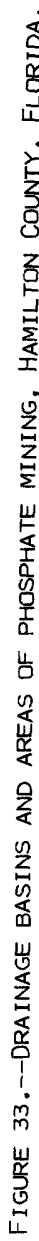


operational shutdowns. The 5- to 25-foot thick matrix contains about 20 percent clay, 60 percent sand, and 20 percent phosphate ore. It is covered with an overburden 10 to 30 feet thick. Three draglines currently (1977) mine about 550 acres per year, and five draglines mined 950 acres a year from both areas until 1977. Mining cuts usually range from 250 to 400 feet in width and up to several hundred yards in length (Sweeney, 1970, p. 11-12).

As the overburden is removed it is side-cast into adjacent cuts; then the matrix is mined and deposited in a suction well or sluice-pit. "Pit-cars" deliver a high pressure (@ 200 psi) stream of water at 10,000 gal/min through hydraulic monitors which slurry the matrix while centrifugal dredge pumps remove and transport the ore to a washer through miles of pipeline at a rate of about $15,000 \mathrm{gal} / \mathrm{min}$. At the washer, the primary slimes (clayey waste) are separated from the large rock and mudballs (waste), the pebble phosphate rock (a product), and the recoveryplant feed (for further processing). Trommel screens remove mud and clay-balls whereas log-washers disintegrate the remaining clay chips. Vibrating, shaker-washer screens separate oversized pebble from the recovery plant feed which continues to the flotation plant.

In the flotation process, materials are selectively separated with various reagents (fatty acids, amine, ammonia, and kerosene). Sand waste (primarily residual quartz/silica) is pumped by slurry to a sand tailings disposal or settling area. Additional slimes (clayey wastes) are circulated through a thickening pond to decrease water entrainment and correspondingly decrease settling-storage pond acreage and shorten recycling time of reclaimed water. Sulfuric acid, caustic soda, and ammonia are added to the flotation system at various times for $\mathrm{pH}$ adjustment. The final phosphate concentrate from the beneficiation plant is either sold or conveyed to the chemical plant for further processing.

The mining and beneficiation stages of the phosphate operations require and (or) create large open areas of water-filled pits, hydraulic canals, drainage ditches, and impounded settling and disposal areas. Water surface thus created is currently (1977) on the order of $10 \mathrm{mi}^{2}$ in area.

\section{Chemical Processing}

The final phosphate concentrate produced from the beneficiation operation, when transported to the chemical plant, can be converted and further concentrated to make superphosphates (normal [NSP], triple [TSP], and granular triple [GTSP]), ammonium phosphates (mono-[MAP] and di-[DAP]), and phosphoric acid (normal wet-process and super). 
Molten sulfur is shipped in to produce sulfuric acid for use in solubilizing the phosphate rock in the conversion to wet-process phosphoric acid (26 to 30 percent $\mathrm{P}_{2} \mathrm{O}_{5}$, merchant grade). Byproducts and impurities of gypsum ( 5 tons for each ton $\mathrm{P}_{2} \mathrm{O}_{5}$ ), hydrofluoric acid, fluosilicic acid, and silica are evolved and must be filtered off or removed by wet-scrubbers. Contaminated water (water with acids and metals) and byproducts are circulated through a gypsum pond settling area where the decant is allowed to overflow and is returned to the plant for reuse. Further concentration of the phosphoric acid (40 to 50 percent $\mathrm{P}_{2} \mathrm{O}_{5}$ ) by evaporation volatilizes some acid and minor impurities which enter a barometric condenser and are recirculated through the gypsum pond. Clarification requires time and temperature to induce chemical precipitation which, along with physical separation, yields more by-products, such as iron and aluminum phosphates, soluble gypsum, and fluosilicates, all of which must be removed.

Other concentrated phosphate products are produced, some of which do not produce quantities of impurities that need be removed. Normal superphosphate uses 65 to 75 percent sulfuric acid and ground or sized phosphate rock. Triple and granulated triple superphosphate utilizes wet-process phosphoric acid and ground or sized phosphate rock to produce 46 to 48.5 percent $\mathrm{P}_{2} \mathrm{O}_{5}$ TSP or GTSP in the form of monocalcium phosphate. Mono- and di-ammonium phosphates (MAP and DAP) are also produced with ammonia and wet-process phosphoric acid.

\section{Water Uses and Activities}

A hydraulic system which covers a large surface area is used to recirculate the waters involved in mining, transportation to the beneficiation plant, primary washer stages, disposal of clay wastes and sand waste, and land reclamation. Floridan aquifer water is pumped into the phosphatic clayey waste storage-settling areas (commonly called slime ponds) until a level is attained that optimizes drainage and flow through the hydraulic system. Phosphatic clayey wastes are deposited at one side of these ponds and hydraulic gradients cause the water released by dewatering of the wastes to overflow on the opposite side of the pond through a spillway into a hydraulic ditch. Ditches surround the storagesettling ponds and some mining areas and are designed to transport recycled water and dike- and pond-seepage back to the plant. This water is then pumped into the plant or to slurry lines to be reused.

Additional water systems are involved in the chemical operation. These are: 1) cooling pond (closed loop), 2) gypsum pond (essentially closed loop), and 3 ) non-process runoff retention basin (discharged into receiving stream after treatment). Water use related to the chemical operation is discussed in this report only to the extent necessary to complete the overview of the phosphate industry operation. 
Once operating levels are attained, most of the water associated with the phosphate operation is recycled (about $305 \mathrm{Mgal} / \mathrm{d}$ ) whereas about $30 \mathrm{Mgal} / \mathrm{d}$ (about 20,800 gal/min) are pumped from the Floridan aquifer for makeup. Certain aspects of the beneficiation and chemical processing currently (1977) require water that is not recycled. This water is obtained from the Floridan aquifer and contains low concentrations of dissolved solids, organics, and certain impurities, such as iron and aluminum. Table 18 summarizes the needs and water systems involved.

Fresh uncontaminated waters are needed: (1) to attain and maintain an efficient operating level in the hydraulic system, (2) for clarification in the floatation stage, (3) for dilution and clarification in the production of sulfuric and concentrated phosphoric acid, (4) for cooling water, and (5) for drinking and sanitary purposes. All other uses do not require freshwater and, therefore, primarily utilize recycled water.

Effects of Phosphate Industry Operations on Streamflow

Surface drainage from the Hamilton County phosphate-mining area (fig. 33) is eastward or southward to the Suwannee River. The principal streams that originate in the general area of mining are Swift, Rocky, Hunter, and Roaring Creeks. The natural drainage pattern has been altered appreciably by phosphate industry activities in Swift and Hunter Creek basins; Rocky Creek basin has not been affected; Roaring Creek basin has been altered slightly, if at all. Swift, Rocky, and Hunter Creek drainage basins originate in and are mostly large flat areas of interconnected swamps and bays that extend generally north and west of the present mining area. Roaring Creek drains a relatively flat, swampy area south and east of the present mining area. In general, streambasin characteristics in eastern Hamilton County are similar to those in Osceola National Forest. Thus, the effects of phosphate industry operations can be appraised by comparing the flow regimens of stream basins in which the operations are located with those of the several stream basins that are similar and nearby but located outside of the mining area.

A comparison of the hydrograph of Swift Creek (fig. 34) with those of Rocky Creek (fig. 35), Deep Creek, Robinson Creek, and Middle Prong St. Marys River (fig. 20) indicates that the phosphate industry operations have altered the pattern of flow in Swift Creek. The pattern of runoff generated by the various storms during the period May 1976 to January 1977 is pronounced and basically similar for the four natural streams. The storm-runoff pattern is not readily apparent from the Swift Creek hydrograph because the flow of Swift Creek persists at a relatively high level during dry spells. For example, during the relatively dry month of August 1976, the average discharges of the four natural streams ranged from 0.02 to $0.05 \mathrm{ft}^{3} / \mathrm{s}$ per $\mathrm{mi}^{2}$ whereas the discharge of Swift Creek averaged $0.77 \mathrm{ft}^{3} / \mathrm{s}$ per $\mathrm{mi}^{2}$. The difference in low flows is 
Table 18.--Summary of Water Needs and Systems in a Phosphate Industry Operation.

\section{Water Use or Activity}

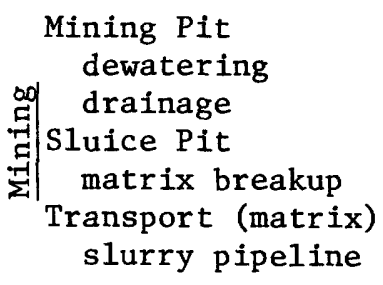
Washer (and feed) screening and sizing
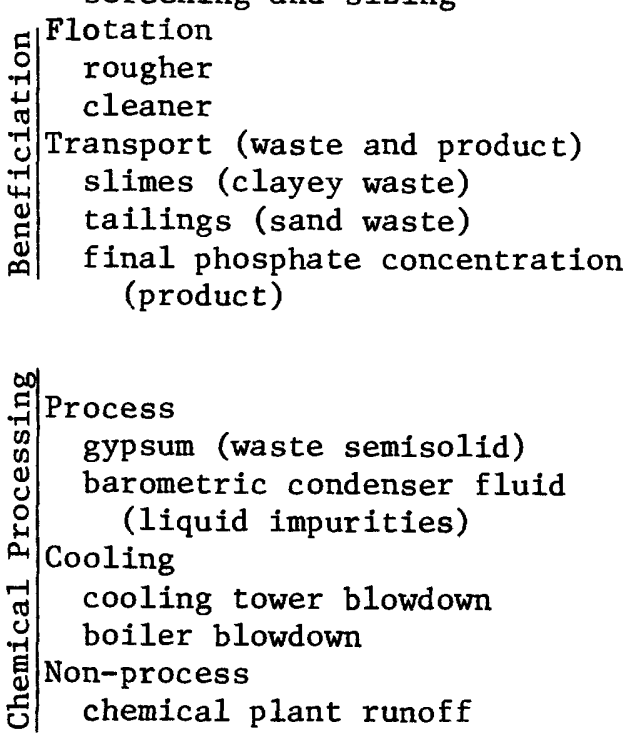

\section{Water System or Source}

Pit seepage (shallow ground water) pumped into hydraulic system or discharged with natural drainage - other mining aspects use hydraulic system water derived initially from deep wells and rainfall.

Beneficiation operations recirculate hydraulic system water within the plant, back into the hydraulic system, or to settling, disposal, and land reclamation areas. Flotation uses most freshwater pumped for the plant.

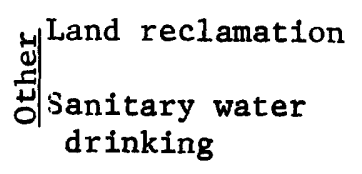

\begin{abstract}
Water contaminated by high concentrations of byproducts or impurities in the chemical processing are circulated through the gypsum pond system. Waters attaining high temperatures and needed for cooling are recycled through a cooling system retention pond. Non-process water runoff from the chemical plant is discharged into a retention pond and treated before discharge to streams. Freshwater needed for evaporation make-up and production loss in cooling and process systems.
\end{abstract}

Much water in land reclamation comes from the hydraulic system used to slurry waste solids back to pits. Additional water comes from rainfall. Freshwater is needed for drinking and sanitary purposes. 


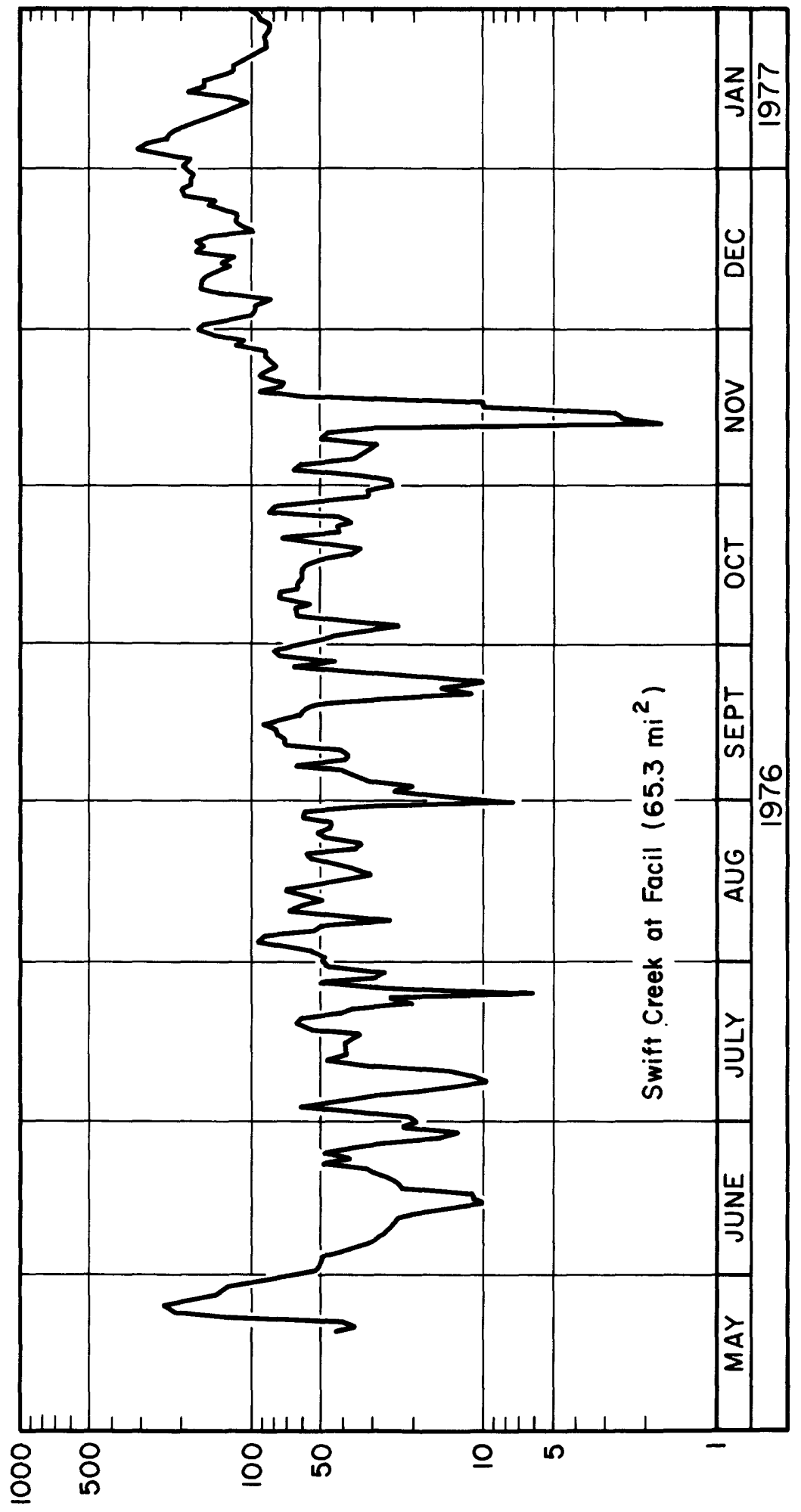

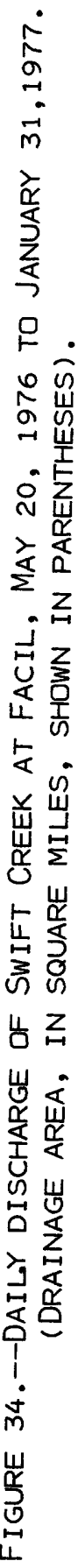
ONOJ $\exists S$ \& $13 \exists \exists$ JI8חJ NI ' $\exists 9 \forall \forall H O S I O$ 


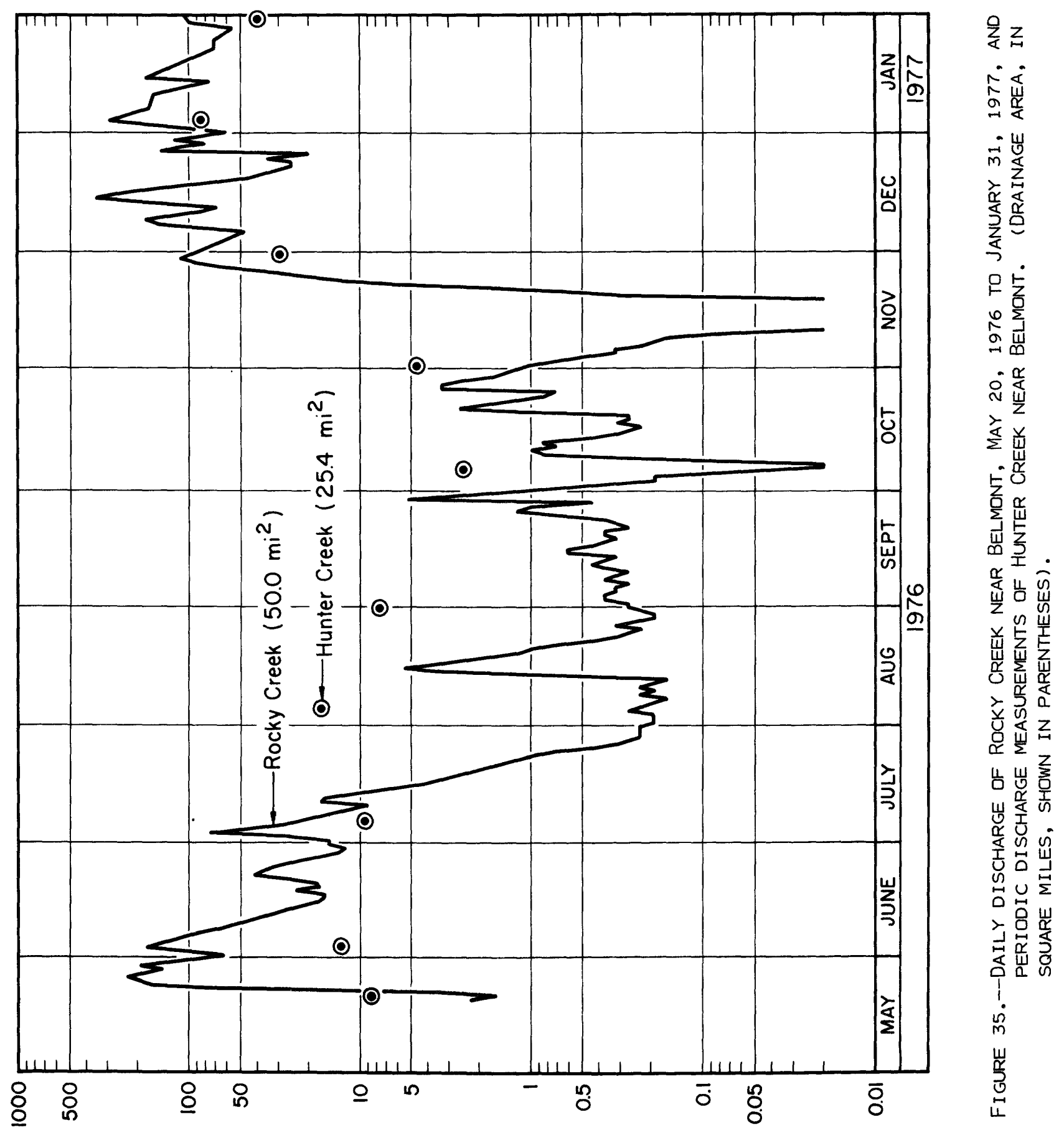

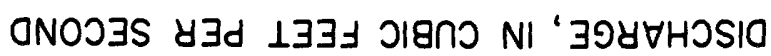


largely due to water that is released into Swift Creek from the phosphate industry operations. The effect is most noticeable during dry spells when the released water makes up a large part of the total flow of the stream. The sudden and somewhat erratic decreases in Swift Creek streamflow (fig. 34) result from the occasional curtailment of releases.

The phosphate industry operations probably have altered the runoff pattern of Hunter Creek but the effect is not as well documented for Hunter Creek as it is for Swift Creek. On the basis of periodic discharge measurements (fig. 35) the flow of Hunter Creek consistently exceeded that of Rocky Creek during periods of natural low flow, even though the drainage area of Hunter Creek is only about half as large as the drainage area of Rocky Creek. The difference in flow is due to release of water into Hunter Creek by the phosphate industry operations.

Water released from the phosphate industry operations consists of overland runoff from rainfall within the confines of the mining complex, water pumped from the Floridan aquifer, and water from the surficial aquifer, including that contained in the phosphate ore. The natural runoff from the mining complex probably is slightly less than that which occurred before operations began because of evaporation from the several water bodies created in the form of phosphatic clayey waste settling ponds, retention ponds, and mined-out pits. The combined area of such water bodies at present (1977) is on the order of $10 \mathrm{mi}^{2}$. In its natural state the mining area probably was similar to Osceola National Forest, in that it was generally flat and swampy, had a relatively high water table over much of the area, and had an evapotranspiration rate of about 40 inches per year. On the assumption that evaporation from open water bodies averages 46 inches per year, the increase in evaporation attributable to the mining operation would be about 6 inches. Applied over an area of $10 \mathrm{mi}^{2}$ a 6 -inch increase in evaporation would equal about $3 \mathrm{Mgal} / \mathrm{d}\left(4.6 \mathrm{ft}^{3} / \mathrm{s}\right)$. Thus, if ground-water seepage from the area has not been changed appreciably by the mining operation, the mining operation should have seemingly reduced the natural runoff by about 3 Mga1/d owing to increased evaporation.

However, the estimated $3 \mathrm{Mgal} / \mathrm{d}$ decrease in natural runoff from the mining operation is more than offset by the ground-water pumpage from the Floridan aquifer that is added to the water-circulation system and subsequently released into Swift and Hunter Creeks. Pumpage averaged $30.3 \mathrm{Mgal} / \mathrm{d}\left(47 \mathrm{ft}^{3} / \mathrm{s}\right.$ ) during 1975 (Leach, 1977, p. 21). Inasmuch as about 10 percent of the pumpage is consumed in the production of phosphate rock and phosphoric-acid concentrate, the net pumpage added to the water-circulation system is about $27 \mathrm{Mgal} / \mathrm{d}\left(42 \mathrm{ft}^{3} / \mathrm{s}\right)$. Thus, the net effect of pumpage from the Floridan by the phosphate industry operations is to increase the runoff by about $24 \mathrm{Mgal} / \mathrm{d}\left(37 \mathrm{ft}^{3} / \mathrm{s}\right)$.

Data were not available for estimating the quantity of water taken from the surficial aquifer as a result of the mining operation and subsequently discharged into Swift and Hunter Creeks. Estimates supplied 
with the plan for a potential phosphate industry operation in Osceola National Forest--to be discussed later in this report--indicate that the quantity of water from this source could be substantial but probably would be considerably less than the quantity of water pumped from the Floridan aquifer. Under natural conditions this water either appears in streams, seeps downward to a deeper aquifer or is evapotranspired. On1y that part of the surficial aquifer water derived from a reduction in downward seepage or evapotranspiration would increase the streamflow.

If the water released from the phosphate industry operations was apportioned between Swift Creek and Hunter Creek in accordance with their drainage areas (Swift Creek: 65.3 $\mathrm{mi}^{2}$; Hunter Creek: 25.4 $\mathrm{mi}^{2}$ ) the net ground-water pumpage would have increased the discharge of these streams by $0.40 \mathrm{ft}^{3} / \mathrm{s}$ per $\mathrm{mi}^{2}$. If all of the released water went into Swift Creek, the net ground-water pumpage would have increased the Swift Creek discharge by $0.57 \mathrm{ft}^{3} / \mathrm{s}$ per $\mathrm{mi}^{2}$. An increase of this magnitude would account for about 53 percent of the discharge measured in Swift Creek at Facil during the 8-month period June 1976 - January 1977. During this period the discharge of Swift Creek averaged $1.07 \mathrm{ft} / \mathrm{s}$ per $\mathrm{mi}^{2}$; the average discharges of Rocky Creek, Deep Creek, Robinson Creek, and Middle Prong St. Marys River ranged from 0.50 to $0.83 \mathrm{ft}^{3} / \mathrm{s}$ per $\mathrm{mi}^{2}$.

The peak flows of Swift Creek and Hunter Creek likely have been attenuated to some degree by the mining operation. Rainfall within the mining complex that previously would have produced runoff directly into Swift and Hunter Creeks now is stored, at least temporarily, in the several water bodies created by the mining operation. At present (1977) this attenuative effect probably is not appreciable because large parts of the two drainage basins still are unaffected by mining. Considerable difference can be expected between peak flows of neighboring basins because of differences in basin size and characteristics and also because of differences in the amount, intensity, and distributional pattern of the rainfall from any given storm. However, the peak flows of Swift Creek appear to be in the same order of magnitude as those of the natural streams in the area. For example, the peak flow (mean daily) occurring near the end of May 1976 (figs. 34 and 35) ranged from 4.0 to $8.8 \mathrm{ft}^{3} / \mathrm{s}$ per $\mathrm{mi}^{2}$ for Rocky Creek, Deep Creek, Robinson Creek, and Middle Prong St. Marys River compared to $3.6 \mathrm{ft}^{3} / \mathrm{s}$ per $\mathrm{mi}^{2}$ for Swift Creek. The peak flow in January 1977 ranged from 2.8 to $5.8 \mathrm{ft} / \mathrm{s}$ per $\mathrm{mi}^{2}$ for the four natural streams compared to $4.7 \mathrm{ft}^{3} / \mathrm{s}$ per $\mathrm{mi}^{2}$ for Swift Creek.

\section{Effects of Phosphate Industry Operations on Surface-Water Quality}

Phosphate-industry operations in eastern Hamilton County are located mainly in the drainage basins of Hunter and Swift Creeks (fig. 33). The water quality of Hunter and Swift Creeks differs from streams draining areas without phosphate operations. Quality of water of Rocky and Roaring Creeks, which drain areas in eastern Hamilton County practically 
unaffected by phosphate-industry operations, is similar to that of the streams draining Osceola National Forest. The water quality of the four Hamilton County streams is summarized in tables 19 and 20 .

Rocky Creek basin and Roaring Creek basin are somewhat comparable in terms of geology, topography, and land use to drainage basins in Osceola National Forest. The quality of water in Rocky and Roaring Creeks, like the water quality of forest streamflow, is characterized by relatively low inorganic ion concentrations (less than $75 \mathrm{mg} / \mathrm{L}$ ), a 1:1 ratio of organic to inorganic constituents, and an acidic $\mathrm{pH}$ ( $\mathrm{pH}$ less than 7.0). However, Rocky Creek had both a higher maximum suspendedsolids concentration ( $27 \mathrm{mg} / \mathrm{L}$ ), and a higher mean suspended-solids concentration $(7 \mathrm{mg} / \mathrm{L})$ than that of any stream in the Osceola Nationa1 Forest. Most of the water-quality parameters for Rocky and Roaring Creeks, like the streams in the National Forest, showed 1ittle variation with discharge. Water quality of Rocky and Roaring Creeks and streams draining the National Forest (Robinson and Deep Creeks, Middle Prong St. Marys River) can be used as approximate baseline or "natural" conditions from which a semiquantitative assessment can be made of streamflow quality that has resulted from phosphate-industry operations.

The southern half of Hunter Creek basin has been disturbed by phosphate mining and beneficiation. A drainage ditch from a mined-out area discharges to the creek and direct overland runoff enters the creek at many places. The higher than natural expected baseflow of Hunter Creek relative to Rocky Creek (fig. 35) presumably results from the mining and benefication operations.

Sampling of the waters from Hunter Creek began in November 1967, about two years after the start of mining activity in Hamilton County. Samples were then collected in May and November of each year in connection with peak- and low-flow investigations. In May 1970, sampling showed an increase in dissolved-solids concentration over that previously observed. This indicated that mining effects were appearing in the Hunter Creek waters. Bimonthly sampling of Hunter Creek waters since August 1971 revealed that water-quality conditions occasionally revert to a "natural" or "near-natural" state when discharge of mining-influenced waters is small or absent. This is indicated in part by the overlap of the observed ranges in chemical quality between Hunter and Rocky Creeks. Therefore, the chemical-constituent ranges for Hunter Creek shown in table 19 reflect the influence of both natural and mining-influenced conditions, at times indicating a dominance of one or the other extreme, but generally indicating a mixture of both.

Dissolved solids (residue) concentrations in Hunter Creek ranged from 73 to $335 \mathrm{mg} / \mathrm{L}$ with a mean of $153 \mathrm{mg} / \mathrm{L}$, compared with a range of 81 to $178 \mathrm{mg} / \mathrm{L}$ and a mean of $135 \mathrm{mg} / \mathrm{L}$ for Rocky Creek. Although the mean dissolved solids (residue) concentration for Hunter is only slightly larger than that for Rocky Creek, the greater range in value is indicative 
Table 19.--Selected Chemical Analyses of Water From Streams in and Adjacent to Phosphate Mining Areas in Hamilton County

(Concentrations are in milligrams per liter and are for dissolved constituents, except as indicated. Samples were collected on Rocky Creek from October 1970 through April 1976; for Roaring Creek from November 1967 through March 1976; for Hunter Creek from November 1967 through April 1977; and for Swift Creek from August 1967 through April 1977.)

\begin{tabular}{|c|c|c|c|c|c|c|c|c|}
\hline \multicolumn{4}{|c|}{ Sampling Site } & \multirow{3}{*}{ 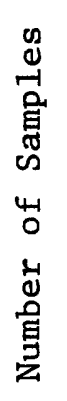 } & \multirow[b]{3}{*}{ Constituent } & \multirow{2}{*}{\multicolumn{3}{|c|}{ Concentration }} \\
\hline \multirow[b]{2}{*}{ 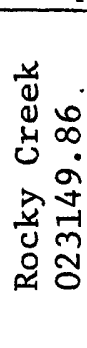 } & \multirow{2}{*}{ 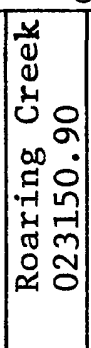 } & \multirow{2}{*}{ 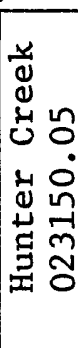 } & \multirow[b]{2}{*}{ 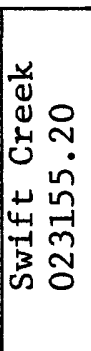 } & & & & & \\
\hline & & & & & & Mean & Range & 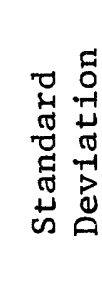 \\
\hline \multirow[t]{3}{*}{$\mathrm{X}$} & $\mathrm{x}$ & & & $\begin{array}{r}16 \\
7\end{array}$ & Calcium (Ca) & 3.9 & $\begin{array}{l}1.5-97 \\
2\end{array}$ & 2.5 \\
\hline & & $\mathrm{x}$ & & 23 & & 19 & $6.6-49$ & 14 \\
\hline & & & $\mathrm{X}$ & 32 & & 46 & $22-80$ & 13 \\
\hline \multirow[t]{4}{*}{$\mathrm{x}$} & & & & 16 & Magnesium (Mg) & 2.1 & $.9-6.0$ & 1.4 \\
\hline & $\mathrm{x}$ & & & 7 & & 3.2 & $1.0-4.8$ & 1.5 \\
\hline & & $\mathrm{X}$ & & 23 & & 7.1 & $2.8-16$ & 4.0 \\
\hline & & & $\mathrm{x}$ & 32 & & 14 & $5.8-21$ & 3.7 \\
\hline \multirow[t]{4}{*}{$\mathrm{x}$} & & & & 16 & Sodium (Na) & 4.7 & $3.0-7.9$ & 1.2 \\
\hline & $\mathrm{x}$ & & & 7 & & 3.8 & $3.6-4.1$ & .2 \\
\hline & & $\mathrm{x}$ & & 23 & & 8.6 & $2.5-20$ & 4.3 \\
\hline & & & $\mathrm{x}$ & 32 & & 29 & $13-62$ & 11 \\
\hline \multirow[t]{4}{*}{$\mathrm{x}$} & & & & 16 & Potassium (K) & .3 & $.1-.9$ & .3 \\
\hline & $\mathrm{x}$ & & & 7 & & .4 & $.0-.8$ & .3 \\
\hline & & $\mathrm{x}$ & & 23 & & .8 & $.2-1.5$ & .4 \\
\hline & & & $\mathrm{x}$ & 32 & & 1.7 & $1.1-2.6$ & .4 \\
\hline \multirow[t]{4}{*}{$\mathrm{X}$} & & & & 16 & Bicarbonate $\left(\mathrm{HCO}_{3}\right)$ & 5.4 & $0-48$ & 12 \\
\hline & $\mathrm{x}$ & & & 7 & & 22 & $0-55$ & 24 \\
\hline & & $\mathrm{X}$ & & 23 & & 36 & $6-73$ & 21 \\
\hline & & & $\mathrm{x}$ & 32 & & 13 & $0-84$ & 17 \\
\hline \multirow[t]{4}{*}{$\mathrm{x}$} & & & & 16 & Chloride (C1) & 7.7 & $5.5-11$ & 1.5 \\
\hline & $\mathrm{X}$ & & & 7 & & 6.8 & $5.5-9.5$ & 1.4 \\
\hline & & $\mathrm{x}$ & & 23 & & 8.4 & $4.0-12$ & 1.9 \\
\hline & & & $\mathrm{x}$ & 32 & & 18 & $4.0-32$ & 7.2 \\
\hline \multirow[t]{3}{*}{$\mathrm{x}$} & $\mathrm{X}$ & & & $\begin{array}{r}15 \\
7\end{array}$ & Sulfate $\left(\mathrm{SO}_{4}\right)$ & 11 & $.0-20$ & 5.8 \\
\hline & $\lambda$ & $\mathrm{X}$ & & 23 & & 42 & $.0-160$ & $50^{2.1}$ \\
\hline & & & $\mathrm{X}$ & 32 & & 153 & $69-290$ & 54 \\
\hline
\end{tabular}


Table 19.--Selected Chemical Analyses of Water From Streams in and Adjacent to Phosphate Mining Areas in Hamilton County (Continued).

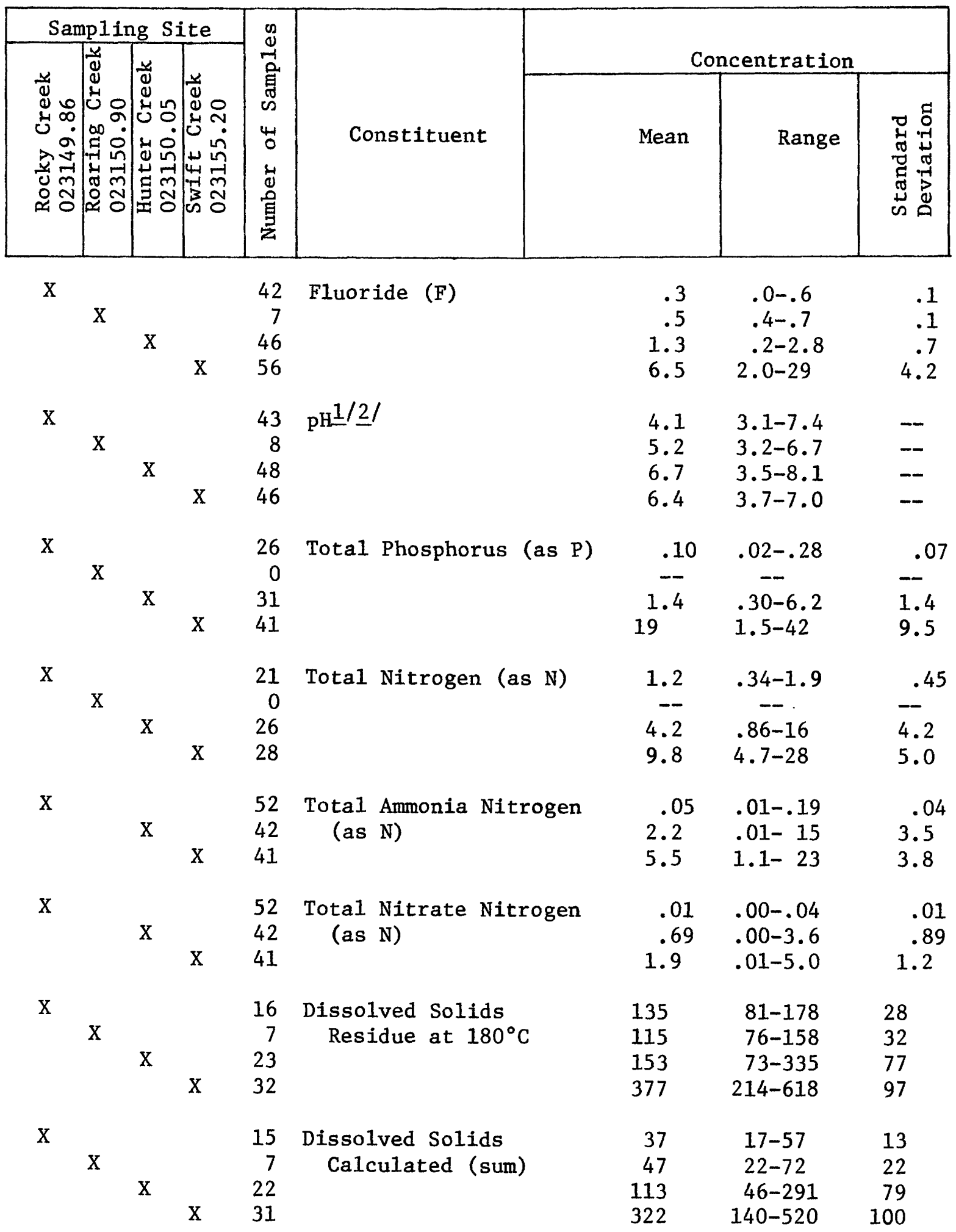


Table 19.--Selected Chemical Analyses of Water From Streams in and Adjacent to Phosphate Mining Areas in Hamilton County (Continued).

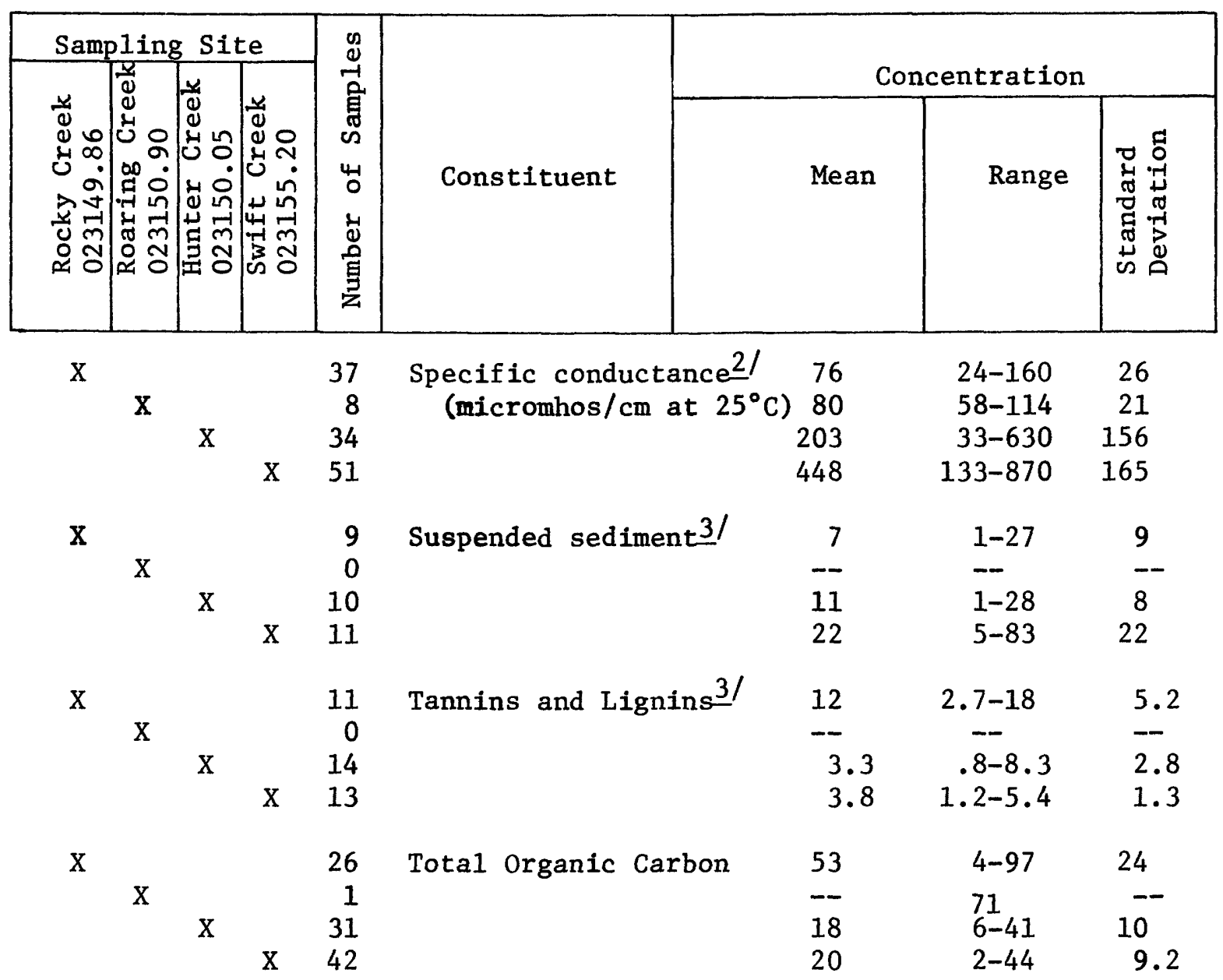

1/ $\mathrm{pH}$ values are given in units. The median of these values are given rather than the mean. 2/ Field determinations.

ㄱ/ Total, not filtered. 
Table 20.--Selected Trace-element Analyses of Water from Streams in and Adjacent to Phosphate Mining Areas in Hamilton County

(Concentrations are in micrograms per liter

\begin{tabular}{|c|c|c|c|}
\hline \multicolumn{3}{|c|}{ Samp1ing Site } & excep \\
\hline & $\overrightarrow{8}$ & & \\
\hline 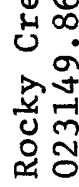 & 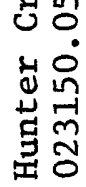 & 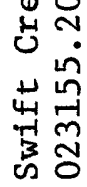 & $\begin{array}{r}\text { Dissolved } \\
\text { Constituent }\end{array}$ \\
\hline
\end{tabular}
except as indicated. Sampling periods are the same as listed in table 19.)

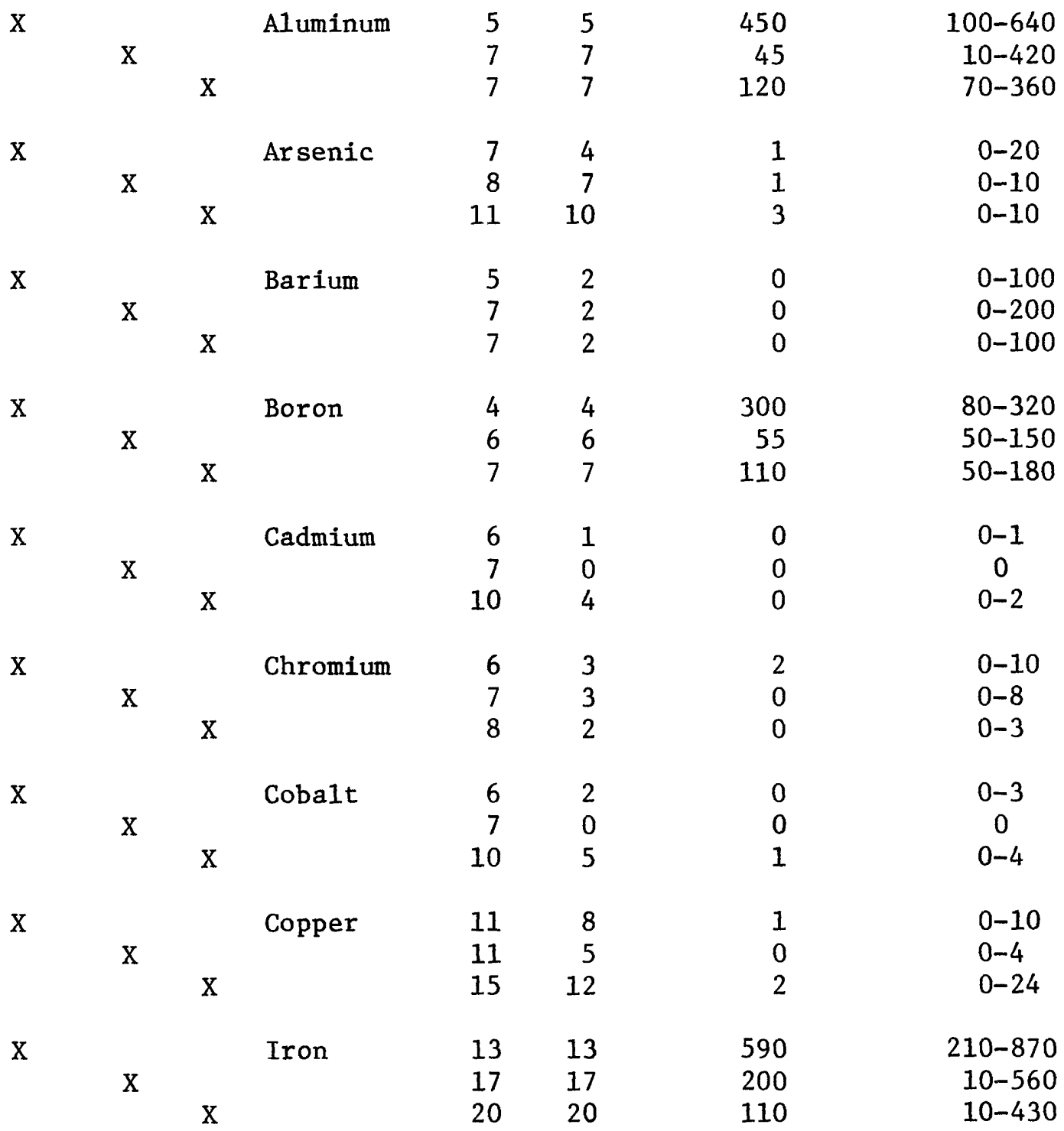


Table 20.--Selected Trace-element Analyses of Water from Streams in and Adjacent to Phosphate Mining Areas in Hamilton County (Continued).

\begin{tabular}{|c|c|c|c|c|c|c|c|}
\hline \multicolumn{3}{|c|}{ Sampling Site } & & & & & \\
\hline \multirow{3}{*}{ 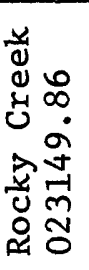 } & \multirow{3}{*}{ 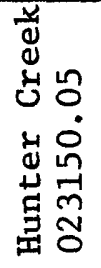 } & \multirow{3}{*}{ 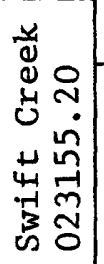 } & & & & & \\
\hline & & & \multirow{2}{*}{$\begin{array}{c}\text { Dissolved } \\
\text { Constituent }\end{array}$} & \multirow{2}{*}{ 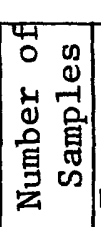 } & \multirow{2}{*}{ 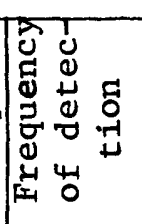 } & \multicolumn{2}{|c|}{ Concentration } \\
\hline & & & & & & Median & Range \\
\hline \multirow[t]{3}{*}{$\mathrm{X}$} & \multirow{3}{*}{$\mathrm{X}$} & & Lead & 13 & 12 & 5 & $0-10$ \\
\hline & & & & 13 & 8 & 2 & $0-10$ \\
\hline & & $\mathrm{X}$ & & 18 & 13 & 2 & $0-20$ \\
\hline \multirow[t]{3}{*}{$\mathrm{X}$} & \multirow{3}{*}{$\mathrm{X}$} & & Lithium & 5 & 1 & 0 & $0-10$ \\
\hline & & & & 7 & 1 & 0 & $0-10$ \\
\hline & & $\mathrm{X}$ & & 7 & 5 & 10 & $0-10$ \\
\hline \multirow[t]{3}{*}{$\mathrm{X}$} & \multirow{3}{*}{$\mathrm{X}$} & & Manganese & 11 & 11 & 30 & $6-50$ \\
\hline & & & & 12 & 11 & 20 & $0-50$ \\
\hline & & $\mathrm{X}$ & & 17 & 17 & 70 & $10-140$ \\
\hline \multirow[t]{3}{*}{$\mathrm{X}$} & \multirow{3}{*}{$\mathrm{X}$} & & Molybdenum & 5 & 3 & 1 & $0-2$ \\
\hline & & & & 7 & 4 & 1 & $0-15$ \\
\hline & & $\mathrm{X}$ & & 7 & 5 & 2 & $0-7$ \\
\hline \multirow[t]{3}{*}{$\mathrm{X}$} & \multirow{3}{*}{$\mathrm{X}$} & & Nickel & 5 & 2 & 0 & $0-3$ \\
\hline & & & & 7 & 2 & 0 & $0-4$ \\
\hline & & $\mathrm{X}$ & & 7 & 6 & 6 & $0-16$ \\
\hline \multirow[t]{3}{*}{$\mathrm{x}$} & \multirow{3}{*}{$\mathrm{X}$} & & Strontium & 16 & 13 & 40 & $0-80$ \\
\hline & & & & 18 & 18 & 50 & $10-100$ \\
\hline & & $\mathrm{X}$ & & 27 & 27 & 95 & $10-280$ \\
\hline \multirow[t]{3}{*}{$\mathrm{X}$} & \multirow{3}{*}{$\mathrm{X}$} & & Uranium & 3 & 3 & .10 & $.07-.40$ \\
\hline & & & & 4 & 4 & .14 & $.03-.20$ \\
\hline & & $\mathrm{X}$ & & 2 & 2 & .30 & $.10-.50$ \\
\hline \multirow[t]{3}{*}{$\mathrm{x}$} & \multirow{3}{*}{$\mathrm{X}$} & & Vanadium & 5 & 0 & 0 & .0 \\
\hline & & & & 7 & 6 & 2.2 & $.0-8.2$ \\
\hline & & $\mathrm{x}$ & & 7 & 7 & 3.2 & $1.0-7.9$ \\
\hline \multirow[t]{3}{*}{$\mathrm{X}$} & \multirow{3}{*}{$\mathrm{X}$} & & Zinc & 11 & 9 & 20 & $0-50$ \\
\hline & & & & 11 & 9 & 10 & $0-20$ \\
\hline & & $\mathrm{X}$ & & 16 & 13 & 10 & $0-460$ \\
\hline \multirow[t]{3}{*}{$\mathrm{X}$} & \multirow{3}{*}{$\mathrm{X}$} & & Radium- & 6 & 6 & .08 & $.03-.24$ \\
\hline & & & $2261 /$ & 8 & 8 & .11 & $.02-.23$ \\
\hline & & $\mathrm{X}$ & & 7 & 7 & .08 & $.05-.20$ \\
\hline
\end{tabular}

1/ Concentration in picocuries per liter. 
of the influence of mining activity. Hunter Creek has a much smaller organic component than does Rocky Creek. Therefore, the larger mean of Hunter Creek represents a larger inorganic input as shown by the dissolved solids (sum) concentrations. The dissolved inorganic (sum) concentrations in Hunter Creek are higher than in Rocky and Roaring Creeks or streams in the National Forest. Dissolved solids (sum) in Hunter Creek ranged from 46 to $291 \mathrm{mg} / \mathrm{L}$ with a mean of $113 \mathrm{mg} / \mathrm{L}$, whereas Rocky Creek had a mean of $37 \mathrm{mg} / \mathrm{L}$, Roaring Creek a mean of $47 \mathrm{mg} / \mathrm{L}$, and Robinson Creek a mean of $42 \mathrm{mg} / \mathrm{L}$--the highest mean concentration for streams draining the National Forest. Concentrations of the dissolved solids (sum) in Hunter Creek do not correlate with variations in discharge. Streams draining unmined or less affected areas exhibit a significant correlation that reflects more input from the surficial aquifer (higher mineralization) at low flow and more input from swamp waters and rainfall (less mineralization) at high flow.

Flow and concentration data for streams draining areas unaffected by phosphate mining can be used to calculate both the estimated amount of mining area discharge contribution and the estimated concentration of mining area discharge to Hunter Creek. The stream discharges are related as follows (adopted from Hem, 1959, p. 231):

or, rearranging:

$$
\begin{aligned}
& q_{1}+q_{2}=q_{3} \\
& q_{2}=q_{3}-q_{1}
\end{aligned}
$$

where

$q_{1}$ is the "natural" discharge

$q_{2}^{1}$ is the mining area discharge

$q_{3}^{2}$ is the total measured discharge of the mixture.

Also,

$$
q_{2} c_{2}=q_{3} c_{3}-q_{1} c_{1}
$$

where the three $c$ terms represent concentrations of constituents at each of the three discharges. The term $q_{2}$ includes runoff from the miningdisrupted areas as well as effluent discharges from the hydraulic system of the mining and beneficiation operations. Thus, the term $q_{2} c_{2}$ would include effects of any ground-water leachate plume that might have formed beneath phosphatic clayey waste settling ponds or other parts of the hydraulic system. However, there may not have been sufficient time for any leachate plumes to migrate to the streams. Variables $q_{3}$ and $c_{3}$ are measured, $q_{1}$ and $c_{1}$ are estimated based on data from streams in the National Forest and from Rocky Creek, and $q_{2}$ and $c_{2}$ are then calculated. Rocky Creek and the National Forest streams all had about the same unit discharge and dissolved solids concentration (residue) on the dates when Hunter Creek was measured (table 21). The table indicates that on these two days during a period of "natural" low flow In Rocky Creek and the National Forest streams, both the water quality and discharge of Hunter Creek were influenced by the mining and beneficiation operations. 


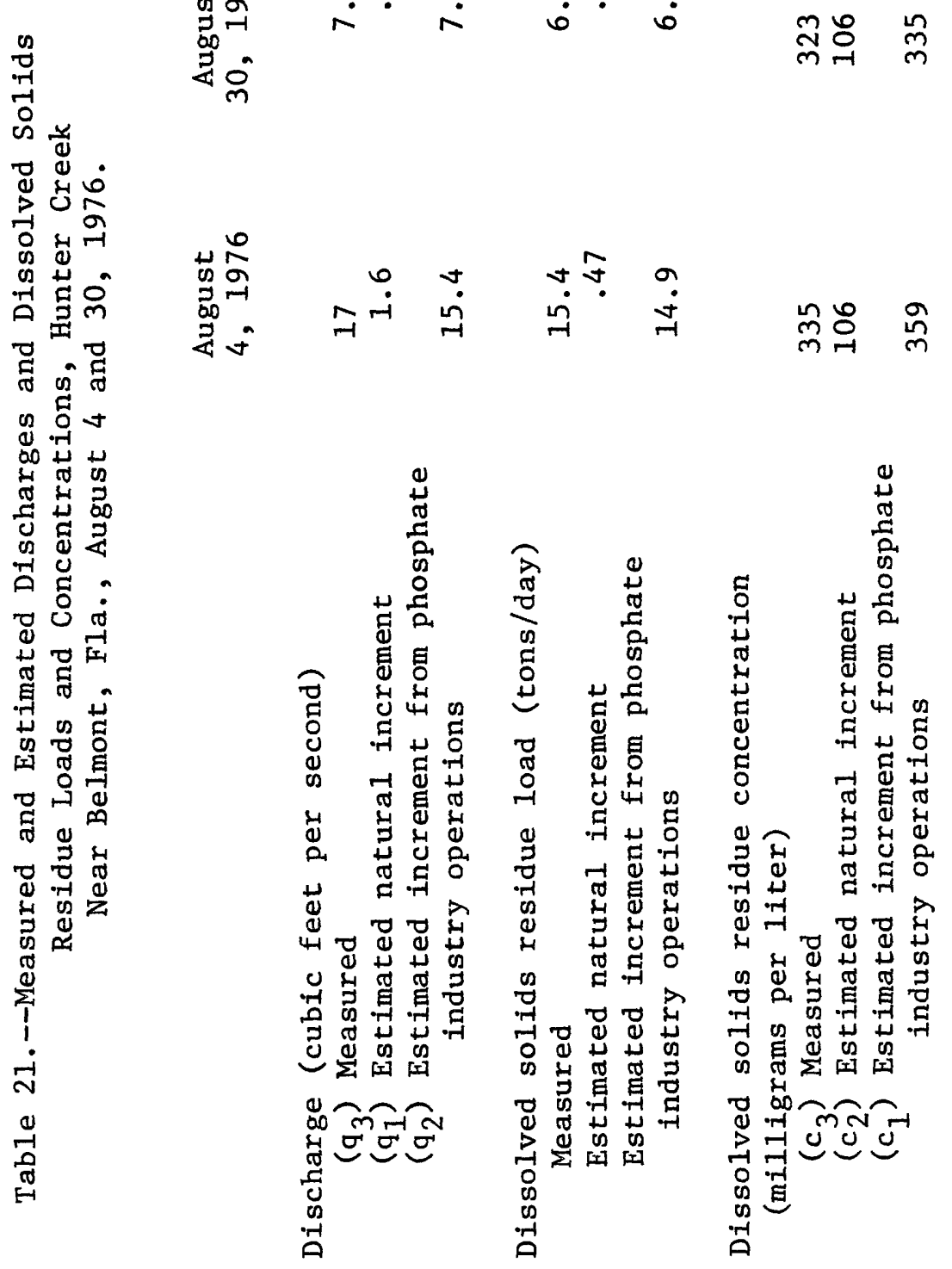


Nitrogen concentrations in Hunter and Swift Creeks are higher than in the natural streams and nitrogen occurs in a different form. As shown in tables 7 and 19, Rocky, Hunter, and Swift Creeks all had higher total nitrogen mean concentrations than the three natural streams in Osceola National Forest. Rocky Creek had total nitrogen concentrations ranging from 0.34 to $1.9 \mathrm{mg} / \mathrm{L}$ with a mean of $1.2 \mathrm{mg} / \mathrm{L}$. The ammonia and nitrate nitrogen concentrations show that most of this nitrogen is of organic origin. Hunter and Swift Creeks had higher ammonia and nitrate nitrogen concentrations, reflecting the use of ammonia nitrogen for $\mathrm{pH}$ control, with Swift Creek additionally reflecting the influence of the production of diammonium phosphate. Total nitrogen in Hunter and Swift Creeks showed a mean of 4.2 and $9.8 \mathrm{mg} / \mathrm{L}$, respectively. Most of this nitrogen was found as ammonia with means of 2.2 and $5.5 \mathrm{mg} / \mathrm{L}$ for the respective streams.

Phosphorous in Hunter Creek, as in other streams in the area, occurred almost exclusively in the form of orthophosphate. Concentrations of total phosphorus in Hunter Creek ranged from $0.3 \mathrm{mg} / \mathrm{L}$ to 6.2 $\mathrm{mg} / \mathrm{L}$ with a mean of $1.4 \mathrm{mg} / \mathrm{L}$. No statistically significant correlation with streamflow was apparent, but higher phosphate concentrations were generally associated with higher dissolved solids (residue) concentrations. In comparison with Rocky Creek and Osceola National Forest streams, in which phosphate concentrations ranged from 0.01 to $0.33 \mathrm{mg} / \mathrm{L}$ and the maximum mean concentration was $0.15 \mathrm{mg} / \mathrm{L}$, Hunter Creek displayed a wider range and higher mean concentration. Sulfate concentrations were also higher in Hunter Creek than in the natural streams, ranging as high as $160 \mathrm{mg} / \mathrm{L}$ with a mean of $42 \mathrm{mg} / \mathrm{L}$, probably as a result of the addition of sulfuric acid for $\mathrm{pH}$ adjustment in the beneficiation process. Rocky Creek had a sulfate concentration ranging as high as $20 \mathrm{mg} / \mathrm{L}$; the National Forest streams ranged up to $13 \mathrm{mg} / \mathrm{L}$, with means less than $10 \mathrm{mg} / \mathrm{L}$. Fluoride concentrations in Hunter Creek ranged from 0.2 to $2.8 \mathrm{mg} / \mathrm{L}$ with a mean of $1.3 \mathrm{mg} / \mathrm{L}$ as compared with a range of 0.0 to $0.7 \mathrm{mg} / \mathrm{L}$ and a maximum mean of $0.5 \mathrm{mg} / \mathrm{L}$ (Roaring Creek) for the five natural streams.

The mean and range of the organic fraction found in Hunter Creek waters are not as large as that found in the natural streams. For example, tannins and lignins in Hunter Creek ranged in concentration from 0.8 to $8.3 \mathrm{mg} / \mathrm{L}$ and had a mean concentration of $3.3 \mathrm{mg} / \mathrm{L}$. Concentrations in Rocky Creek and the streams in the National Forest ranged from $1.2 \mathrm{mg} / \mathrm{L}$ to $18 \mathrm{mg} / \mathrm{L}$ with means ranging from 7.4 to $12 \mathrm{mg} / \mathrm{L}$. Total organic carbon content in Hunter Creek streamflow ranged from 6 to 41 $\mathrm{mg} / \mathrm{L}$ with a mean of $18 \mathrm{mg} / \mathrm{L}$. Based on the dissolved solids (sum) and the total organic carbon content, the organic to inorganic ratio for Hunter Creek was about $1: 7$ as compared with 1:1 for the natural streams. High flows that carry high concentrations of organic material from swamps in the natural streams did not occur in Hunter Creek, probably because a large part of Hunter Creek basin has been cleared and mined, and swamp area has been reduced. As with the other streams, the pH of Hunter Creek streamflow tended to decrease with increased discharge; however, the median (6.6) and maximum (8.1) $\mathrm{pH}$ were higher than in natural streams. It therefore appears that the stream quality of Hunter Creek is affected by both phosphate mining and beneficiation activities, although apparently not continuously. 
Radium-226 concentrations in Hunter Creek waters ranged from 0.02 to $0.23 \mathrm{pCi} / \mathrm{L}$ with a median of $0.11 \mathrm{pCi} / \mathrm{L}$, or about the same as that of Rocky Creek ( 0.03 to $0.24 \mathrm{pCi} / \mathrm{L}$, median of $0.08 \mathrm{pCI} / \mathrm{L}$ ) and only slightly higher than those of the National Forest streams. Correlation with discharge was not shown to be significant. As the range and median concentration of radium-226 in Hunter Creek was about that of the natural waters, it is concluded that the mining and beneficiation operations did not add significantly to the concentrations of this radionuclide in Hunter Creek.

Suspended-sediment concentrations in Hunter Creek were in general higher than those of the natural streams. The range from 1 to $28 \mathrm{mg} / \mathrm{L}$ was about the same as that for Rocky Creek, but about three times that of 0sceola National Forest streams. The mean concentration of suspended sediment for Hunter Creek was, however, over half again that for Rocky Creek and three to four times that for the other natural streams. Regression analysis showed that increases in suspended sediment accompanied increases in discharge for Hunter Creek. Because the mean daily discharge for Hunter Creek is not known the mean daily suspended sediment load cannot be computed.

Swift Creek is the primary receiving stream for effluent from the mining, beneficiation, and chemical processing areas. The discharge of Swift Creek is controlled mainly by releases from holding areas such as phosphatic clayey waste settling ponds. Flow from mining and (or) beneficiation operations and the natural drainage from Swift Creek Swamp are the largest sources of water in Swift Creek. Chemical plant area discharges may affect Swift Creek water quality depending on the specific source of the discharge and the amount of dilution from other sources.

On October 18 and 19, 1976, water samples were collected at selected locations within and adjacent to phosphate industry operations in Hamilton County in order to identify the chemical quality of various inputs to Swift and Hunter Creeks. Figure 36 shows the geographic location of the sampling points and the resulting chemical determinations. Figure 37 is a schematic diagram showing the location of the sampling points in relation to sources of water. Sampling points numbers 7,22 , and 27 represent water from the hydraulic system draining the phosphatic clayey waste settling and storage ponds associated with the mining and beneficiation operations. Sample point number 5 represents the discharge from Swift Creek Swamp, which includes some discharge from the Swift Creek beneficiation and mining area operations. Sample point number 4 represents the combined flow from the Suwannee River mining area (point number 7) plus, on that date, non-process water discharged from the chemical plant area. Sample point number 6 represents the combined flow from points 4 and 5 at a location upstream from the regular Swift Creek sampling point at the intersection of the creek with U.S. Highway 41 at Facil, Florida. 


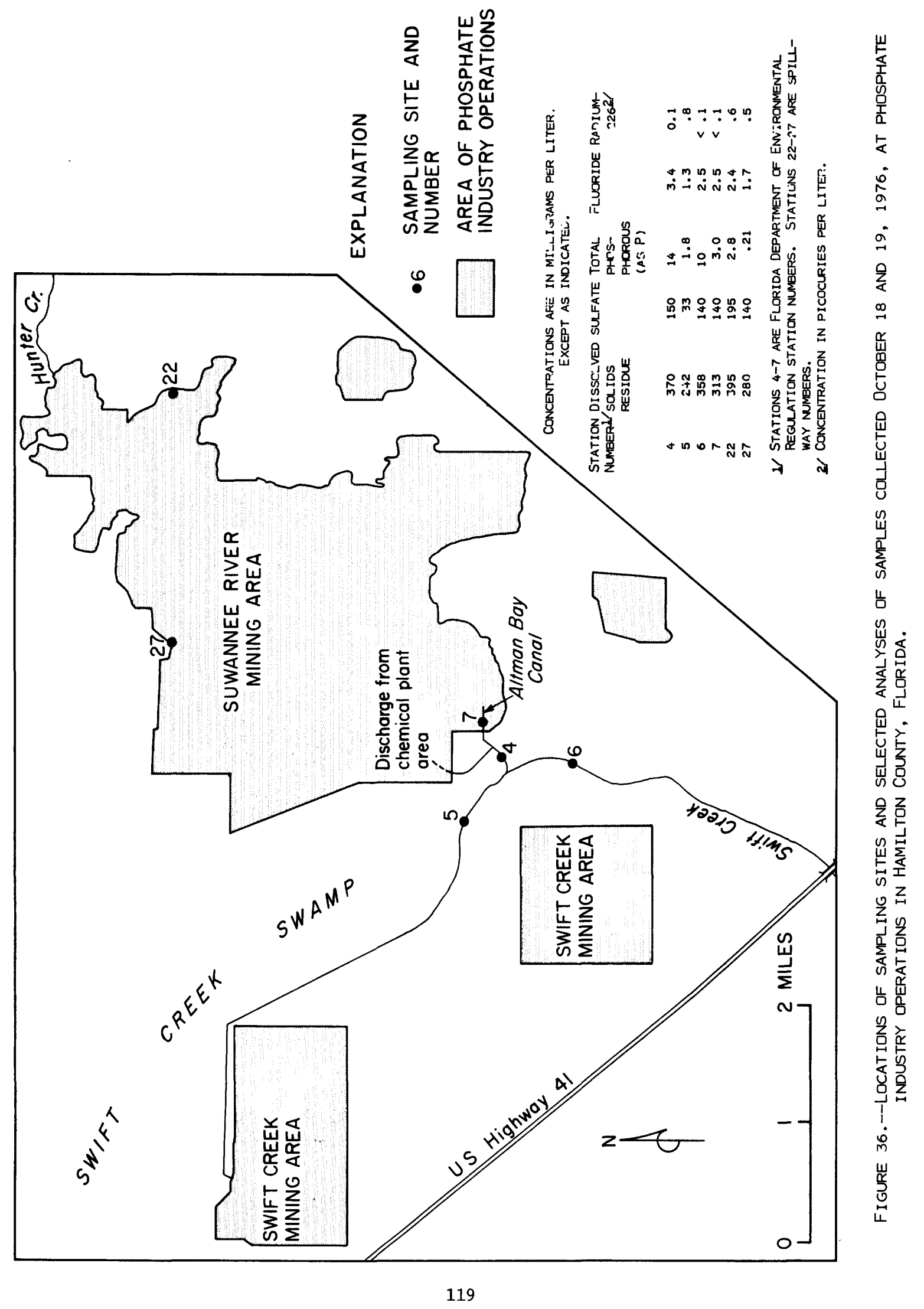




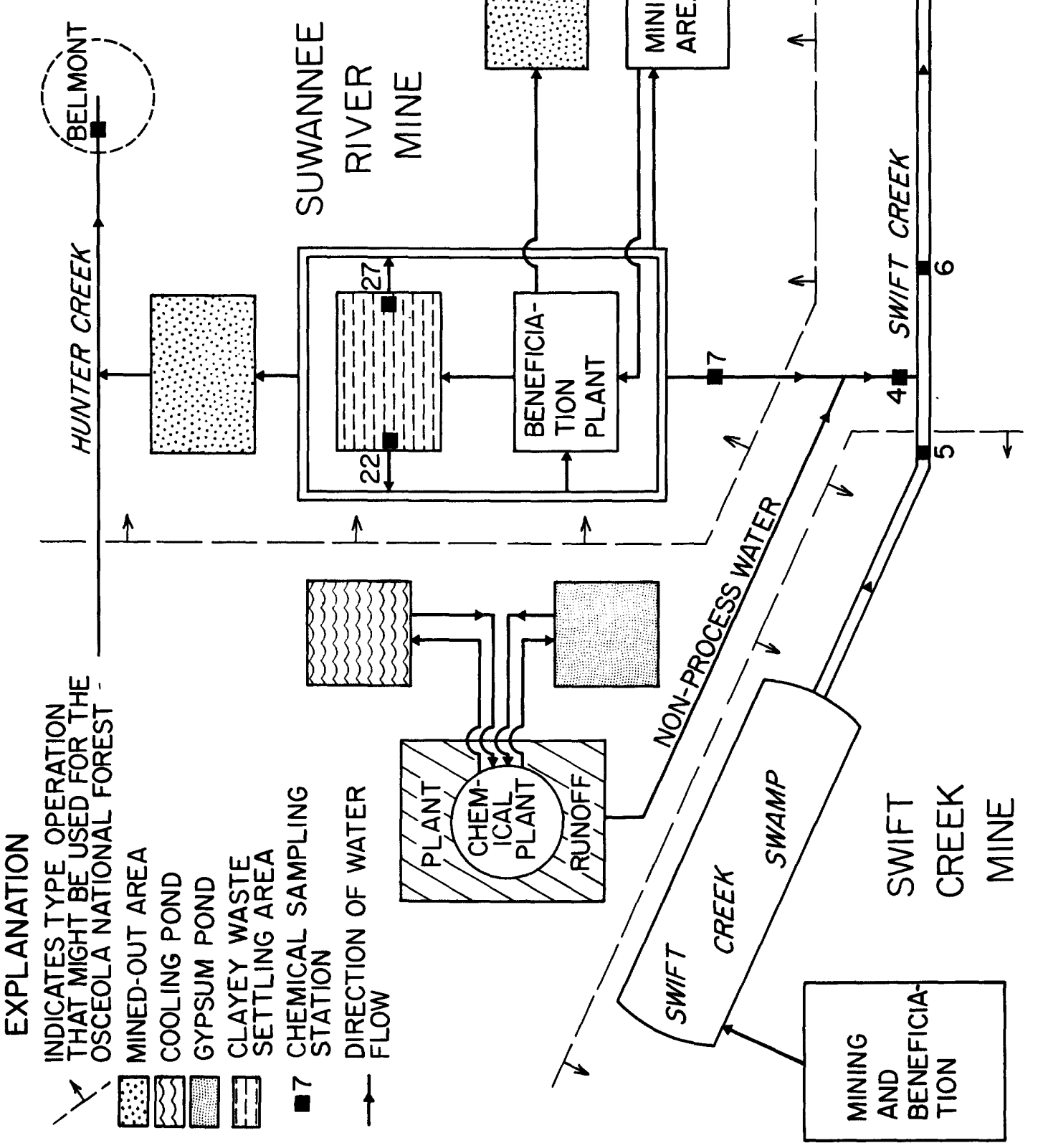

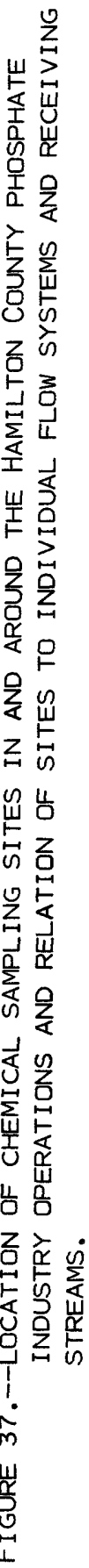


The results of this sampling indicate that the dissolved solids (residue) concentrations in the hydraulic system at the points of discharge from the phosphatic clayey waste settling and storage ponds (stations 7, 22, and 27) averaged about $330 \mathrm{mg} / \mathrm{L}$, similar to that measured in August 1976 in Hunter Creek. This value is somewhat greater than the median concentration, $290 \mathrm{mg} / \mathrm{L}$, in the Floridan aquifer water that is pumped from wells into the hydraulic system and which makes up much of the hydraulic-system water. Concentrations of sulfate averaged about $160 \mathrm{mg} / \mathrm{L}$, the upper limit of concentrations observed in Hunter Creek. Likewise, the mean fluoride concentration $(2.2 \mathrm{mg} / \mathrm{L})$ of these three samples was in the higher range of Hunter Creek samples. Total phosphorous concentrations at sample points $5,7,22$, and 27 indicated that concentrations in the hydraulic system, or mining-beneficiation waters, were similar to the mean of Hunter Creek samples. The dissolved solids concentrations (residue) observed at these stations is about equal to the value estimated previously (table 21) for Hunter Creek in August 1976 as being derived from phosphate industry operations. The greatest phosphorous input to Swift Creek came from the non-process water that entered between sample points 4 and 7 and was discharged from the chemical plant area. Thus, it appears that the chemical plant area discharge, at least on that date, contributed a slightly higher dissolved solids and several times higher phosphate concentration than did the discharge of other phosphate industry waters.

Total phosphorous concentrations in Swift Creek at the gaging station near Facil, Florida, based on samples collected from August 1967 through April 1977, ranged from 1.5 to $42 \mathrm{mg} / \mathrm{L}$ with a mean of $19 \mathrm{mg} / \mathrm{L}$. These concentrations are higher than those of Osceola National Forest streams (range of 0.01 to $0.33 \mathrm{mg} / \mathrm{L}$ ) or of Rocky Creek (range of 0.02 to $0.28 \mathrm{mg} / \mathrm{L})$. The higher concentrations in Swift Creek waters relative to Hunter Creek waters are due to the input from the chemical plant area. Sulfate concentrations in Swift Creek ranged from 69 to $290 \mathrm{mg} / \mathrm{L}$ with a mean of $153 \mathrm{mg} / \mathrm{L}$, higher than that in the natural streams (concentrations up to $20 \mathrm{mg} / \mathrm{L}$ ). The sulfate content of Swift Creek tended to decrease with increased streamflow. Fluoride concentrations in Swift Creek ranged from 2.0 to $29 \mathrm{mg} / \mathrm{L}$ with a mean of $6.5 \mathrm{mg} / \mathrm{L}$, higher than concentrations in the natural streams (range up to 0.6). Concentrations of these constituents could not be statistically correlated with changes in discharge.

Dissolved solids (calculated sum) concentrations for Swift Creek ranged from 140 to $520 \mathrm{mg} / \mathrm{L}$ with a mean of $322 \mathrm{mg} / \mathrm{L}$, whereas dissolved solids (residue) concentrations ranged from 214 to $618 \mathrm{mg} / \mathrm{L}$ with a mean of $377 \mathrm{mg} / \mathrm{L}$. Both dissolved solids measurements indicated higher values than for streams not affected by phosphate industry operations. Mean daily dissolved solids (residue) concentrations estimated from continuous conductance records and a linear regression relating conductance and dissolved solids (residue) ranged from 222 to $507 \mathrm{mg} / \mathrm{L}$ and averaged $342 \mathrm{mg} / \mathrm{L}$ from May 1976 through April 1977. 
Tannins and lignins ranged in concentration from 1.2 to $5.4 \mathrm{mg} / \mathrm{L}$ for Swift Creek with a mean of $3.8 \mathrm{mg} / \mathrm{L}$, generally less than concentrations in the National Forest streams (range 1.2 to $13 \mathrm{mg} / \mathrm{L}$, means of 0.4 to $8.5 \mathrm{mg} / \mathrm{L}$ ) and Rocky Creek (range 2.7 to $18 \mathrm{mg} / \mathrm{L}$, mean of 12 $\mathrm{mg} / \mathrm{L}$ ). Total organic carbon ranged from 2 to $44 \mathrm{mg} / \mathrm{L}$ in concentration with a mean of $20 \mathrm{mg} / \mathrm{L}$, again generally lower than concentrations in the National Forest streams (range 16 to $50 \mathrm{mg} / \mathrm{L}$, means 33 to $37 \mathrm{mg} / \mathrm{L}$ ) and in Rocky Creek (range 4 to $97 \mathrm{mg} / \mathrm{L}$, mean $53 \mathrm{mg} / \mathrm{L}$ ). The organic to inorganic ratio in Swift Creek waters was about 1:16 compared with 1:7 for Hunter Creek and 1:1 for the natural streams. This probably reflects the lessened influence of swamp waters and the artificial control of Swift Creek discharge.

Radium-226 concentrations in Swift Creek ranged from 0.05 to 0.20 $\mathrm{pCi} / \mathrm{L}$ with a median of $0.08 \mathrm{pCi} / \mathrm{L}$ during the period of study, which is comparable to concentrations in the "natural" streams. Therefore, radium-226 concentrations in Swift Creek waters have not been enriched appreciably by discharge from any of the phosphate industry operations. No correlation was found between the radium-226 concentrations and discharge. Concentrations of other trace elements are given in table 20 .

Suspended-sediment concentrations in Swift Creek ranged from 5 to $83 \mathrm{mg} / \mathrm{L}$ with a mean of $22 \mathrm{mg} / \mathrm{L}$. These values are higher than for the natural streams (range of 1 to $27 \mathrm{mg} / \mathrm{L}$, means of 3 to $7 \mathrm{mg} / \mathrm{L}$ ). The comparatively high suspended-sediment concentrations probably result from mining-pit discharge and runoff from non-stabilized surfaces associated with strip mining. The higher concentrations in Swift Creek were generally associated with high discharges.

The median $\mathrm{pH}$ of Swift Creek (6.4) was higher than that of the natural streams ( $\mathrm{pH}$ range of 4.1-5.2). Manganese, nicke1, and strontium had higher median concentrations in Swift Creek waters than in natural waters.

In summary, the water quality of Hunter and Swift Creeks is different from that of the natural streams in eastern Hamilton County and Osceola National Forest and reflects the influence of phosphate industry operations on water quality. Waters in Hunter and Swift Creeks contain higher concentrations of dissolved solids, sulfate, fluoride, phosphorus, nitrogen, suspended sediment, and have a higher $\mathrm{pH}$, than natural streams. However, these concentrations, except for fluoride, still meet drinking water standards. The primary drinking water standard for fluoride (U. S. Environmental Protection Agency, 1975) is $1.8 \mathrm{mg} / \mathrm{L}$ for an average annual air temperature of $68.7^{\circ} \mathrm{F}$ : mean fluoride concentration in Swift Creek was $6.5 \mathrm{mg} / \mathrm{L}$ and the maximum concentration was $29 \mathrm{mg} / \mathrm{L}$. Swift Creek water quality is influenced by drainage from the chemical plant area, exhibiting higher concentrations of some constituents than other industry water. Hunter Creek is affected only by mining and beneficiation operations. Radium-226 concentrations were not higher than those in natural streamflow. 
Water pumped from the Floridan aquifer constitutes a large part of the water used in the phosphate industry operations. Consequently, concentrations of many dissolved constituents in water discharged to Hunter and Swift Creeks by the phosphate industry operations in large part reflect the concentrations of constituents occurring in Floridan ground water.

\section{Effects of Phosphate Industry Operations on Ground Water}

Phosphate industry activities in Hamilton County have changed the character of the surficial aquifer and the direction and rate of movement of water through it in and around the area of the mining operations. The topography has been changed from generally flat to gently rolling, and the few open surface water bodies have been expanded to cover an area on the order of $10 \mathrm{mi}^{2}$. Where the surficial aquifer materials have been excavated to remove the phosphate ore and redeposited as backfill in the mined-out trenches, the aquifer has become more heterogeneous and less stratified than before. The resulting material is poorly sorted and less compacted, and thus has new permeability and storage characteristics.

The water table is lowered in the area of the active mining pit during the dewatering operations accompanying the ore extraction. Shortly after dewatering is suspended, the water table recovers and its altitude and configuration reflect the modified topography and altered hydraulic characteristics of the surficial aquifer.

Quality of water in the surficial aquifer has probably been affected, but no wells for sampling were available to document the magnitude of these changes. Aeration of materials during excavation and backfilling has modified the geochemical equilibrium conditions and produced a potentially more reactive environment. Leachate, if any were present, from the phosphatic clayey waste settling ponds, cooling retention pond, and gypsum ponds could have produced water-quality changes in the surficial aquifer beneath and downgradient from the ponds. The cooling retention pond and gypsum ponds are associated with the chemical processing plant and have the greatest potential to change the quality of water because of higher concentrations of constituents than those occurring in the original ground water in the surficial aquifer.

Lowering of the potentiometric surface of the Floridan aquifer in the vicinity of supply wells has occurred. Long-term records from an observation well in Jennings, a well 3.5 miles west of White Springs, a well in Lake City, and a well near Valdosta, Georgia, have not shown any pronounced long-term water-level decline if climatic variations are taken into account. Therefore, based on these records, a significant regional decline of the Floridan's potentiometric surface has not resulted from the $30 \mathrm{Mgal} / \mathrm{d}$ of pumpage for the phosphate industry operations. This pumpage probably has been balanced by either an increase in recharge to the Floridan from vertical leakage or from capture of streamflow, or both. 
POTENTIAL PHOSPHATE INDUSTRY OPERATIONS IN OSCEOLA NATIONAL FOREST

\section{General}

The U. S. Bureau of Mines prepared a report for the Geological Survey that presents a plan for hypothetical mines and beneficiation plants, including water needs, for phosphate industry operations in Osceola National Forest which would likely follow issuance of Federal preference right leases now pending before the Department of Interior. The report, dated May 1977, and entitled "Water Demands of two Logical Phosphate Mining Units, Osceola National Forest", was prepared by Dr. Allen T. Cole, a consultant from Lakeland, Florida, under contract to the U. S. Bureau of Mines, and is endorsed by the Bureau. This report is summarized below ( $p .124-127$ ).

The Bureau of Mines suggests that there are no economically and technically feasibile alternatives to strip mining, to beneficiation of the phosphate ore by washing and flotation processes, or to locating beneficiation plants within the National Forest if the preference right lease applications now pending are issued. A chemical plant is not envisioned within the National Forest; thus it is assumed that any such plant, if needed, would be located on private land. Dr. Cole indicates that the methods described for mining, transporting, and beneficiating the ore are generally those commonly used by the phosphate industry throughout Florida. Waste disposal practices are specified for only the first three years of operation. Waste disposal beyond that time is left dependent on the feasibility of various land reclamation plans currently under study. Hence, land reclamation practices were not specifically addressed.

\section{Summary of Mining P1an}

Two hypothetical mining areas are proposed, as shown on figure 38 , each to be mined with 2 draglines at a rate of 2 million tons per year of phosphate concentrate over approximately 530 acres per year per mining area. The potential duration of mining is 28 years for 14,840 acres in area $A$ to the north, and 22 years for 11,660 acres in area $B$ to the south. A total production of phosphate concentrate of 56 million short tons from area $A$ and 44 million short tons from area $B$ is envisioned. A beneficiation plant, a settling-storage pond for phosphatic clayey waste, and a tailings pile are assumed to be located near the center of each mining area, as shown on figure 38.

The plan envisions that after the first five years of operation, sand tailings would be piled to a height of 33 feet above grade on 560 acres of unmined land in each mining area. For the first three years of mining, phosphatic clayey waste would be impounded in 820-acre settlingstorage ponds constructed above grade with dikes built to a height of 41 or 42 feet on unmined land, one pond near each plant. These ponds could be periodically dewatered. 


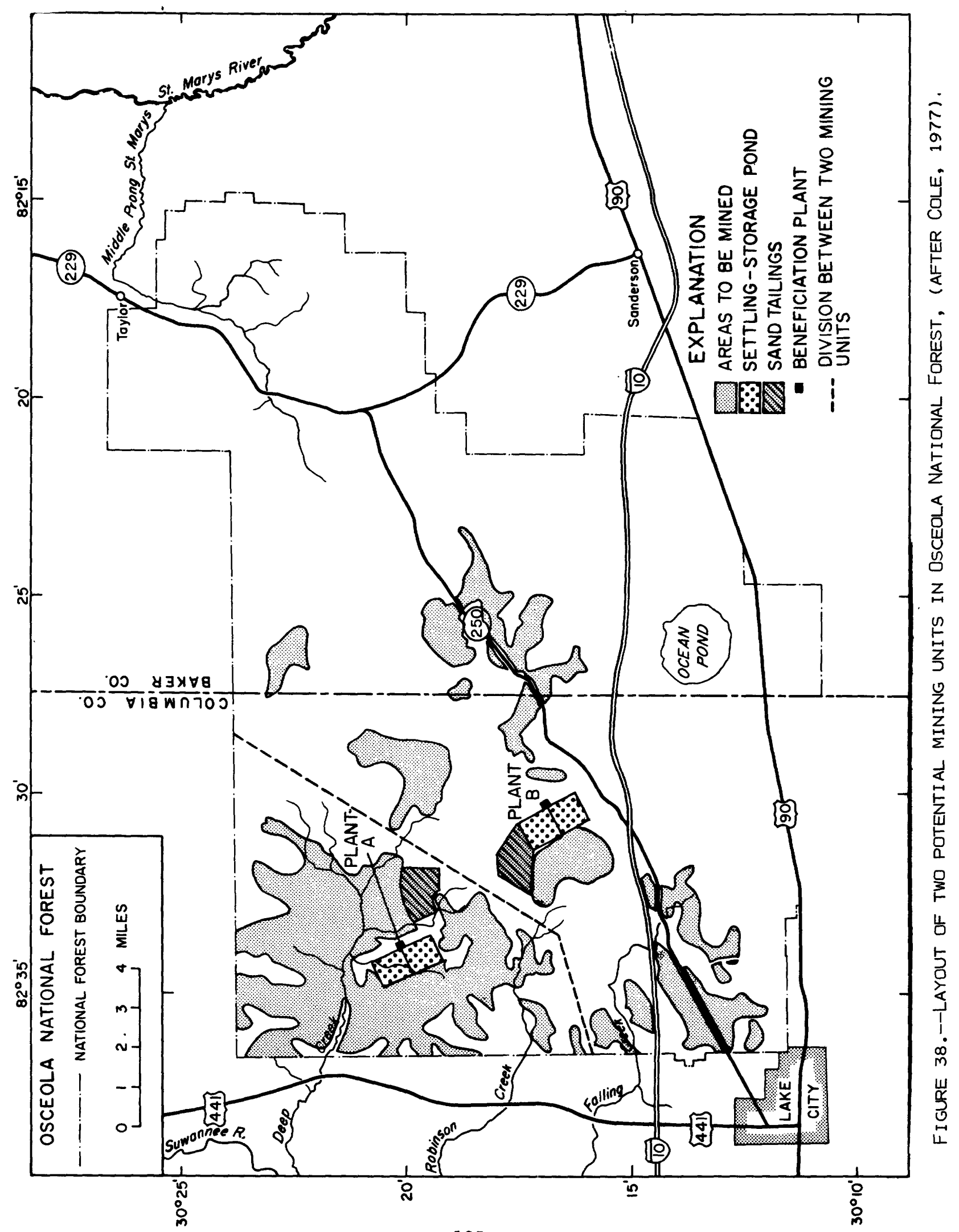


If such a plan were to be followed, 2,300 acres of standing water would remain in each mining area based on the amount of voids created by the removal of the phosphate ore, for a total of 4,600 acres of standing water after redistribution of the overburden. In mining area $A$, the 2,300 acres would be concentrated behind a dam on Deep Creek in the northwest corner of the National Forest. In mining area B, the 2,300 acres would be distributed throughout the mining area.

\section{Summary of Water Demands}

\section{Use of Water}

In Florida phosphate industry operations, water is generally needed for: (1) disintegration and slurrying of the ore at the pit, (2) transportation of ore by slurry from pit to beneficiation plant, then through wet screening or classifying devices, (3) transportation of waste products to settling ponds or other waste disposal areas, (4) separation of phosphate from impurities in the flotation process, and (5) drinking and sanitary supply for the plant area.

In the transportation process, water is reclaimed from waste disposal areas, after suspended clayey and sandy wastes settle out, and recycled into the system. Some of this recycled water can also be used in certain parts of the flotation process.

\section{Quality of Water}

Water-quality control is not very critical in the fatty acid or anionic flotation process, nor in wet sizing except for transportation of the clay-free feed. Clear water is required to transport the "deslimed" wet-sized or washer product to further beneficiation circuits. Swamp waters that contain tannic or other inorganic acids cause problems. Turbid water is detrimental to the separation processes. Slightly alkaline water is preferred to decrease reagent costs.

The amine or cationic flotation process is sensitive to water quality. In this process, deep well water is generally used because it possesses the desired qualities of low suspended solids content and a constant $\mathrm{pH}$. Water for drinking and sanitation must meet the standards of the U. S. Environmental Protection Agency and the State of Florida.

\section{Sources of Water}

Potential sources of water available to the phosphate mining and beneficiation operations are: (1) creeks and rivers, (2) rainfa1l, (3) deep wells, (4) drainage ditches, and (5) mining pits. Creeks and rivers were not considered as feasible sources for mining purposes. Creeks in the National Forest are small and are not dependable sources of water. The Suwannee River is distant from the potential mining areas besides being highly variable in quality and quantity. 
Rainfall would be stored to the extent that the water system can retain it. Deep wells tapping the Floridan aquifer would provide a reliable and adequate supply of water of suitable quality. Perimeter drainage ditches around mining and mined-out areas would accumulate water, the amount of which would vary with rainfall and would also be influenced by the location of the ditches. Pit water would be obtained mostly from seepage from the pit walls, but also would include rainfall collected in the pit.

\section{Losses of Water}

Water would be lost from the flow system through: (1) discharge from outfall or spillways, (2) evaporation, (3) retention of water in clayey waste, and (4) moisture in the final phosphate product. Water would be discharged into a receiving stream whenever the quantity of water added by rainfall, pit water, and pumping exceeds the storage capacity of the system. Evaporation loss would occur from the surface of ponds and lakes in the water-clarification system.

\section{Water Balance}

A water-use diagram prepared by using flowsheets from washer, feed preparation, and flotation circuits shows that about $78,800 \mathrm{gal} / \mathrm{min}$ are required by each mining unit. Most of this water can be recycled. Water-balance calculations indicate demand for about $9,400 \mathrm{gal} / \mathrm{min}$ of makeup water for each mining unit which can be met by about $5,100 \mathrm{gal} / \mathrm{min}$ pumpage from deep wells, $1,600 \mathrm{gal} / \mathrm{min}$ pit water, and $2,700 \mathrm{gal} / \mathrm{min}$ of water mined with the saturated ore. About $50 \mathrm{gal} / \mathrm{min}$ of the pumpage from deep wells would be needed for drinking and sanitary purposes. The volume of water contained in the final product would be equivalent to a pumping rate of about $360 \mathrm{gal} / \mathrm{min}$.

In order to place 10 feet of water $(8,200$ acre-feet) in the initial settling system at startup, it would be necessary to pump $8,200 \mathrm{gal} / \mathrm{min}$ for six months $(6,540$ acre-feet) from three $3,000 \mathrm{gal} / \mathrm{min}$ (design capacity)

- deep wells. Rainfall and pumps in perimeter ditches would suppIy the balance $(1,660$ acre-feet) of the startup water required. After startup, an available supply of $6,000 \mathrm{gal} / \mathrm{min}$ from wells at each mining unit was assumed to be supplied from two $3,000 \mathrm{gal} / \mathrm{min}$ wells at each unit; a third well at each mining unit would be used as a spare or standby well. 
IMPACT OF POTENTIAL PHOSPHATE MINING AND

BENEFICIATION OPERATIONS ON THE HYDROLOGIC SYSTEM

OF OSCEOLA NATIONAL FOREST

Effects on Surface Water

Water Budget of the Potential Phosphate Industry Operations

The water budget of the potential phosphate industry operations relates to the water that enters, leaves, or is stored in the hydraulic system of the phosphate mining and beneficiation processes. The general magnitude of the quantity of water that will be discharged from the hydraulic system, given the hypothetical mining plan, is estimated for a single mining unit, using average annual values.

The water entering the hydraulic system consists of rainfall on the open ponds and ditches that are part of the hydraulic system, water pumped from the active mining pit, water added that was part of the mined ore, and pumpage from Floridan aquifer wells. Water leaving the system consists of water evaporated from ponds and ditches, water in the finished phosphate product, and water that is discharged to maintain the system within operational 1imits. Seepage through the dikes or levees around settling ponds presumably would be caught in perimeter ditches and pumped back into the hydraulic system. Seepage through the pond bottoms and runoff from areas adjacent to ponds and ditches were not considered to contribute significantly to the quantity of water within the system and were disregarded.

It is assumed that the principal ponds in each hydraulic system which would be subject to gains and losses of water by rainfall and evaporation would be the 560-acre sand-tailings pond and the 820 -acre phosphatic clayey waste settling pond. In the vicinity of the actual mining operation, an open water area ranging from 0 to 530 acres and averaging 265 acres per year would exist. The average annual rainfall is taken to be 54 inches and average annual evaporation from the ponds is taken to be 46 inches.

Initially, the only space available for storing water in the hydraulic system would be the 33-ft deep, 560-acre tailings pond (18,480 acre-ft) and the 42-ft deep, 820-acre phosphatic clayey waste settling pond $(34,440$ acre-ft). Assuming that the overburden would be contained within the mine pits, the only other permanent storage created within the hydraulic system is that represented by the final phosphate product. At an assumed density of 150 pounds per cubic foot, the annual production of 2 million tons of phosphate rock would have a volume of about $2.7 \times 10^{7}$ $\mathrm{ft}^{3}$ or 620 acre-ft. Thus, the mining operation would create an additional storage capacity of 620 acre-ft per year. The storage capacity of the various pipelines, tanks, and ditches in the water-circulation system presumably would be filled by the 8,200 acre-ft of water added to the system before mining begins. 
Water inputs and outputs of the hydraulic system that can be estimated directly for each mining unit are:

Inputs

Rainfal1 on 1,645 acres of openwater surface

Pit water $\underline{1 /}$

Saturated ore $\underline{1 /}$

Pumpage from deep wells $1 /$

Subtota1

\section{$\underline{\mathrm{Ga} 1 / \mathrm{min}}$}

$$
4,588
$$

1,600

2,664

5,072

13,924
Acre-ft/year $\mathrm{ft} \mathrm{t}^{3} / \mathrm{s}$

10.22

$$
7,402
$$

2,581

3.56

5.94

4,297

8,100

11.30

22,380

31.02

\section{(Outputs)}

Evaporation from 1,645 acres

of open-water surface

$(3,909)$

$(6,306)$

(362)

$(4,271)$

9,600

\section{(584)}

$(6,890)$

15,500
(8.70)

$(.81)$

21.4

ROUNDED TOTAL (Inputs minus Outputs)

I/ from Cole, 1977.

The difference of about 9,600-gal/min or 15,500-acre-ft/year between the estimated inputs and outputs represents the quantity of water that must be either discharged from or stored in the hydraulic system. Given an initial storage capacity of 52,920 acre-ft and additional storage created at a rate of 620 acre-ft per year, the excess water could be stored for the first three and one-half years of operation. Sometime during the fourth year of operation and subsequently, excess water would have to be discharged from the hydraulic system at a rate averaging about 9,600 gal/min or about $21.4 \mathrm{ft}^{3} / \mathrm{s}$ for each mining unit.

\section{Distribution of Phosphate-Ore Deposits}

The 26,500 acres of ore deposits involved in possible leasing and future mining are distributed in the four drainage basins as follows:

Acres Percent of total

Deep Creek basin

Middle Prong St. Marys

River basin

Falling Creek basin

Robinson Creek basin

Tota1
$16,000 \quad 60$

\begin{tabular}{rr}
4,500 & 17 \\
4,000 & 15 \\
2,000 & 8 \\
\hline 26,500 & 100
\end{tabular}


Within the National Forest boundaries the ore deposits underlie 38 percent of Deep Creek basin, 25 percent of Falling Creek basin, 16 percent of Robinson Creek basin, and 6 percent of Middle Prong St. Marys River basin. The ore deposits underlie about 28 percent of the entire Deep Creek drainage basin upstream of the western boundary of the National Forest, including that part of the basin which lies north of the National Forest.

\section{Streamflow Characteristics}

Because of the relatively flat land surface, the natural drainage divides are indistinct in some parts of the forest. Interchange of water between stream basins probably occurs naturally when rainfall is exceptionally heavy in the vicinity of basin divides. Some of the areas proposed for mining straddle drainage-basin divides and mining operations likely would change these basin divides. The magnitude of such changes would depend on the extent of the levees and canals, on their general alignment, and on the extent to which they are modified by reclamation procedures as mining proceeds over the years. The effect of the mining operation on basin divides cannot be evaluated without a detailed mining and reclamation plan. However, some generalizations on the streamflow characteristics of various basins can be made.

Swamp or upland areas would be converted into ponded-water areas throughout the mined area. The acreage of such ponded-water areas would increase from zero at the start of mining operations to 4,600 acres for the two mining areas at the end of the operation. On the assumption that evaporation from the ponded-water areas would average 46 inches per year, an increase over the original evapotranspiration of 40 inches per year, the natural runoff from the mined areas would be decreased by 6 inches (disregarding leakage from the surficial aquifer to the Floridan aquifer) or about $1,400 \mathrm{gal} / \mathrm{min}$ overall. This decrease in natural runoff would continue after the end of the mining operation. On the assumption that the new ponded-water areas would be apportioned according to the mineable acreage in the four stream basins, the average annual reduction in natural streamflow at the end of mining would average 840 gal/min (1.87 $\left.\mathrm{ft}^{3} / \mathrm{s}\right)$ for Deep Creek, $240 \mathrm{gal} / \mathrm{min}\left(0.53 \mathrm{ft}^{3} / \mathrm{s}\right)$ for Middle Prong St. Marys River, $210 \mathrm{gal} / \mathrm{min}\left(0.47 \mathrm{ft}^{3} / \mathrm{s}\right)$ for Falling Creek, and $110 \mathrm{gal} / \mathrm{min}\left(0.24 \mathrm{ft}^{3} / \mathrm{s}\right)$ for Robinson Creek. In relation to the present (1977) natural flow, such long-term reductions after mining ceases would be about 2.1 percent of the estimated average annual discharge for Deep Creek, 1.4 percent for Falling Creek, 0.6 percent for Robinson Creek, and 0.5 percent for Middle Prong St. Marys River.

As a result of mining, the land surface and water table might be permanently raised in parts of the forest and the water table might be lowered by drainage ditches elsewhere. Consequently, evapotranspiration would be decreased and runoff increased, partly offsetting the decrease in runnoff attributed to the ponded-water areas. 
Original stream channels in the potential mining areas would be totally disrupted and flow would be diverted around the mine pits in manmade ditches or canals. To the extent that such diversions would Increase or decrease channel storage, flood peaks would be either attenuated or accentuated. To the extent that the storage created in the abandoned mine pits is included in the altered flow paths, flood peaks would be reduced. The effect of increases or decreases in storage would be slight during the first few years of the mining operation because only small parts of the drainage basins would be affected. The potential for affecting flood peaks would be greatest in Deep Creek basin because about 28 percent of the total basin upstream of the western forest boundary would be mined. The decrease of flood peaks would not be appreciable in Middle Prong St. Marys River basin because the mined-out areas would represent only a small percentage of the total basin area.

During the mining, the quantity of streamflow from individual basins would be changed by interbasin transfer of water through the mining and beneficiation hydraulic systems. The flow of the stream receiving effluent from the hydraulic systems would therefore be increased at the expense of other basins from which water were pumped into the system. Moreover, the discharge of water pumped from the Floridan aquifer to the effluent-receiving stream would increase the flow of that stream considerably.

The beneficiation plants of both hypothetical mining units are located in Deep Creek basin, but the plant for unit B is near the DeepRobinson Creek basin divide. Although the hydraulic system of unit $B$ might discharge effluent into Robinson Creek, it is herein assumed that both systems would discharge into Deep Creek. It is also assumed that in any year one mine pit (encompassing 530 acres) would be operated in Deep Creek basin and the other would be operated in one of the other three basins--Robinson Creek, Falling Creek, or Middle Prong St. Marys River.

The transfer of pit and ore waters from Robinson Creek, Fal1ing Creek or Middle Prong St. Marys River basins would decrease the runoff from the basin by an amount less than that extracted. The water extracted from the pit would be derived from or replaced by water, part of which ordinarily would have been evapotranspired and part of which would have been discharged to the stream, in proportions assumed to be similar to the ratio of evapotranspiration to runoff under natural conditions. Accordingly, the runoff of the basin involved would be decreased by an estimated 25 percent of the water pumped from the pit ( $400 \mathrm{gal} / \mathrm{min}$ ), and extracted with the ore (666 gal/min), which totals $2.4 \mathrm{ft}^{3} / \mathrm{s}$. The same reduction in runoff would apply to Deep Creek basin in that one pit would be operated there yearly.

Reductions in surface runoff due to increased downward leakage induced by pumpage from the Floridan aquifer would be negligible because, as shown later, the increase in leakage would be small. 
The former natural runoff from Deep Creek basin would be further reduced by the incorporation of $5.1 \mathrm{mi}^{2}$ of the basin's surface into the hydraulic systems of the two plants, and as the average annual unit runoff of the basin was estimated to be $1.0 \mathrm{ft}^{3} / \mathrm{s}$ per $\mathrm{mi}^{2}$, the total reduction from this cause would be $5.1 \mathrm{ft}^{3} / \mathrm{s}$.

The $5.1 \mathrm{mi}^{2}$ area would still produce runoff, but through the hydraulic systems at a reduced rate of $0.57 \mathrm{ft} / \mathrm{s}$ per $\mathrm{mi}^{2}$ or a total of $2.9 \mathrm{ft} / \mathrm{s}$. The reduction in runoff results from conversion of the $5.1 \mathrm{mi}^{2}$ area to perennially ponded water with attendant increase in evaporation to 46 inches per year compared with the pre-mining evapotranspiration loss of 40 inches per year.

The expected average discharge of Deep Creek during mining, therefore, can be estimated as follows:

Former natural yield $\left(88.6 \mathrm{ft}^{3} / \mathrm{s}\right)$, minus the loss due to decrease in basin size $\left(5.1 \mathrm{ft}^{3} / \mathrm{s}\right)$ and the pit and ore-water extraction in Deep Creek basin $\left(2.4 \mathrm{ft}^{3} / \mathrm{s}\right)$, plus discharge from the two plants $\left(42.8 \mathrm{ft}^{3} / \mathrm{s}\right)$ equalling a total of $123.9 \mathrm{ft}^{3} / \mathrm{s}$.

In summary, with both of the mining units in operation, their combined effects would be to increase the flow of Deep Creek by 35 $\mathrm{ft}^{3} / \mathrm{s}$, more than 60 percent of which would come from the Floridan aquifer pumpage. The flow of Robinson Creek, Falling Creek, and Middle Prong St. Marys River would be decreased by about $2.4 \mathrm{ft}^{3} / \mathrm{s}$ individually during years when their basins were being mined.

For Deep Creek the flow would average $1.40 \mathrm{ft}^{3} / \mathrm{s}$ per $\mathrm{mi}^{2}$ compared to the estimated natural average annual discharge of $1.0 \mathrm{ft}^{3} / \mathrm{s}$ per $\mathrm{mi}^{2}$. For Robinson Creek, Falling Creek, and Middle Prong St. Marys River the flow owing to exportation of water by the hydraulic system would be 1.31 , 1.30 , and $0.78 \mathrm{ft}^{3} / \mathrm{s}$ per $\mathrm{mi}^{2}$, a decrease of $0.09,0.10$, and $0.02 \mathrm{ft}^{3} / \mathrm{s}$ per $\mathrm{mi}^{2}$ respectively, compared to estimated natural average annual discharges of $1.40,1.40$, and $0.80 \mathrm{ft}^{3} / \mathrm{s}$ per $\mathrm{mi}^{2}$, respectively.

As long as the two mining units were kept in continuous operation, the quantity of the discharge from the hydraulic system probably would be relatively uniform throughout the year with some variation related to variations in rainfal1. Thus, the discharge from the hydraulic systems would substantially augment the natural low flows of Deep Creek which are commonly less than $10 \mathrm{ft}^{3} / \mathrm{s}$ (fig. 20). During the mining operations the low-flow pattern of Deep Creek probably would be similar to that presently occurring in Swift Creek (fig. 34). Inasmuch as the natural peak discharges of Deep Creek are common1y on the order of 200 to 300 $\mathrm{ft}^{3} / \mathrm{s}$ or greater, the routine releases of water from the hydraulic systems probably would not markedly affect the peak discharges resulting from the more severe periods of rainfall. 
Although the natural flows of Robinson Creek, Falling Creek, and Middle Prong St. Marys River at times are less than $2.4 \mathrm{ft}^{3} / \mathrm{s}$ (fig. 20), the estimated $2.4 \mathrm{ft}^{3} / \mathrm{s}$ decrease in the average flow of these streams owing to the exportation of water would not necessarily cause these streams to dry up. Most, if not all, of the reduction in runoff that would result from the pumping of pit water and the replacement of water withdrawn with the saturated ore probably would occur during and immediately following appreciable rainfall, or at a time when most of the natural runoff occurs.

\section{Surface-Water Quality}

The degree to which the water quality of streams draining the Osceola National Forest would be affected by the potential phosphate industry operations would depend partly on the type of land reclamation practices followed and partly on the way in which mining and beneficiation areas are developed. The location of mined areas and the sequence in which they are mined, the location of settling-storage ponds needed after the initial pond is filled, and the progression of other activities and their respective locations will all affect stream quality.

In areas being mined or reclaimed, the most noticeable changes in stream quality would result from draining and clearing of swampland and forest. Erosion and aeration or oxidation of both organic and inorganic materials would occur, producing an increase in suspended sediment and a decrease in the concentration of organic constituents relative to inorganic constituents in runoff from those areas. Additional changes could occur if leachate plumes formed and migrated to a stream. Since the hypothetical mining plan included no chemical plant in the National Forest, such a plume would be associated only with phosphatic clayey waste settling ponds and not with gypsum or cooling ponds.

Changes in the water quality of the stream(s) receiving discharge from mining and beneficiation activities will vary depending on the relative contribution to the stream(s) from two potential main sources. At the beginning of mining, comparatively small areas of a drainage basin are directly affected by phosphate industry operations. As mining proceeds, the component of natural discharge diminishes in its influence, in terms of both quality and quantity, relative to the component of discharge affected by mining and beneficiation. The two potential main sources are related to the total discharge and stream quality as follows:

$$
q_{1} c_{1}+q_{2} c_{2}=q_{3} c_{3}
$$

where

$q_{1} c_{1}$ is discharge times concentration for natural conditions. 
$q_{2} c_{2}$ is discharge times concentration for mining-influenced conditions.

$q_{3} c_{3}^{2}$ is total discharge times concentration, neglecting chemical and physical reactions.

Equation (9) can be used to calculate the concentration of constituents in a stream receiving effluent from potential phosphate industry operations. For example, assuming that Deep Creek would receive all the discharge from the two potential mining units (fig. 38), dissolved solids (residue) concentration may be calculated for Deep Creek, using values developed earlier in this report. The average discharge of. Deep Creek basin $\left(88.6 \mathrm{ft}^{3} / \mathrm{s}\right)$ is decreased $5.1 \mathrm{ft}^{3} / \mathrm{s}$ due to incorporation of part of the basin into the hydraulic systems of two mining units. The resulting natural yield of Deep Creek $\left(q_{1}\right)$ is therefore $83.5 \mathrm{ft}^{3} / \mathrm{s}$. The mean dissolved solids (residue) concentration for Deep Creek $\left(c_{1}\right)$ is $100 \mathrm{mg} / \mathrm{L}$ from table 7. Average discharge from the two mining units $\left(q_{2}\right)$ is $42.8 \mathrm{ft}^{3} / \mathrm{s}$ (p. 132). Mean dissolved solids (residue) of this discharge $\left(c_{2}\right)$ is about $334 \mathrm{mg} / \mathrm{L}$ (table 22). When the above values are substituted in equation (9), $q_{3}$ would be $126.3 \mathrm{ft}^{3} / \mathrm{s}$ and $c_{3}$ would be about $179 \mathrm{mg} / \mathrm{L}$. Similar calculations may be done for other constituents so long as the effects of chemical reaction, precipitation, adsorption, and desorption are neglected. Results of calculations for other constituents in Deep Creek are listed in table 23.

Table 22 shows concentrations of fluoride in excess of the primary drinking water standard for the artificial discharges for the mining and beneficiation operations in Hamilton County. Hunter Creek, on at least the two dates listed, also exceeded these limits. It is possible that fluoride concentrations in Deep Creek would also exceed these standards. Estimated concentrations of other constituents as calculated (table 23) were not in excess of the 1imits given by the U. S. Environmental Protection Agency $(1976,1977)$.

On a daily basis, however, conditions could vary considerably from the average as they do for Hunter Creek (table 19). At times discharge from the phosphate industry operations might be withheld entirely and, thus, at those times the quality of Deep Creek water would resemble the quality of natural streamflow. On the other hand, at times when the component of natural flow is small, discharges from the phosphate mining and beneficiation operations might obscure the natural streamflow, resulting in streamflow quality approaching the quality of effluent as shown by the earlier mass balance (p. 115 and table 21). Even at this extreme, fluoride probably would be the only constituent to exceed the maximum contaminant levels for drinking water, although the nitrate concentration may approach these levels if or when other nitrogen forms are converted to nitrate. 

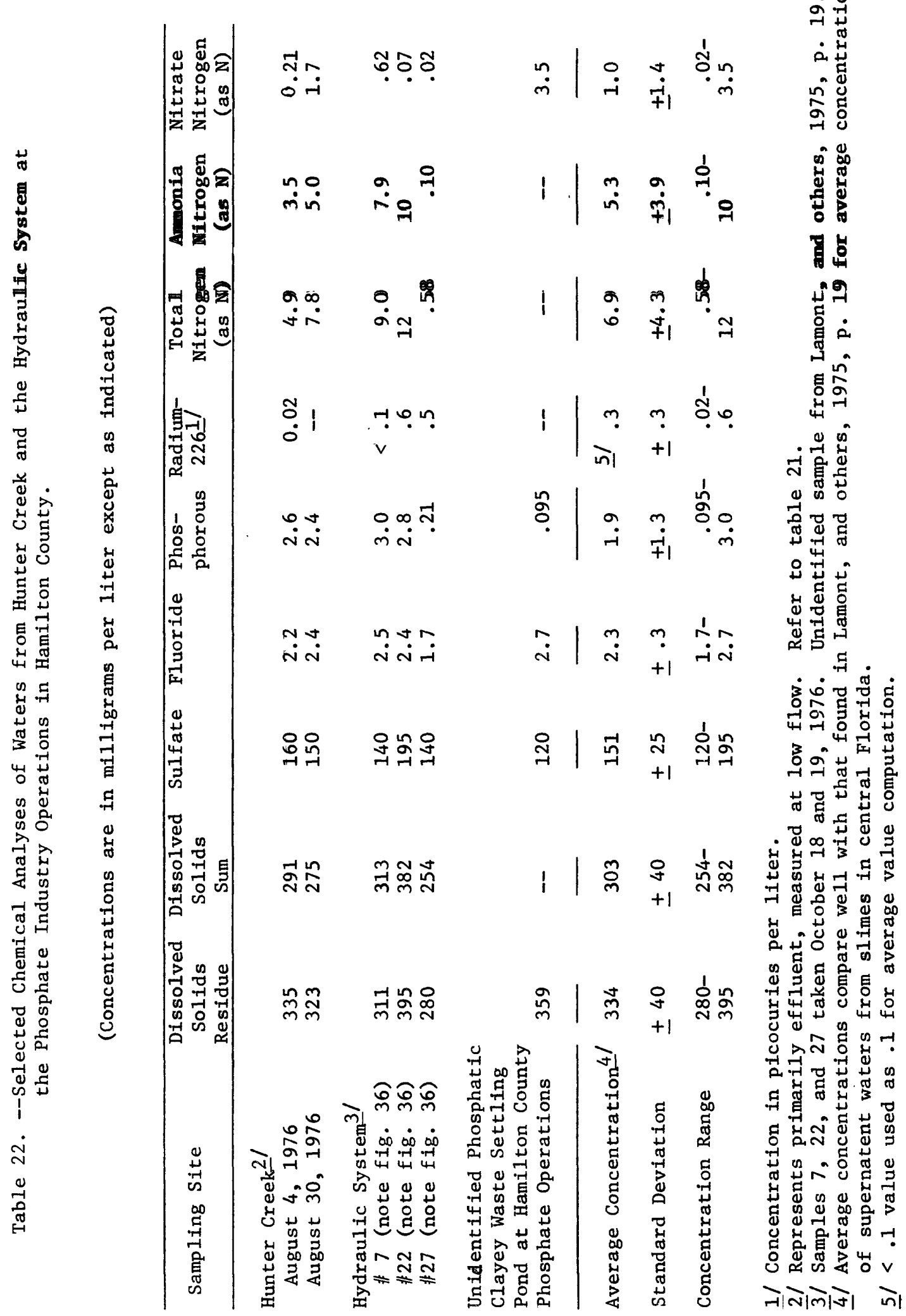
Table 23.--Comparison of Average Concentrations of Selected Constituents in Natural Flow of Deep Creek, in Effluent from Phosphate Mining Beneficiation Operations, and in Estimated Deep Creek Mixed Flow.

\begin{tabular}{|c|c|c|c|c|c|c|c|}
\hline \multirow{2}{*}{\multicolumn{2}{|c|}{ Water Source }} & \multicolumn{6}{|c|}{$\begin{array}{l}\text { (Dissolved concentrations, in milligrams per 11ter } \\
\text { except as indicated) }\end{array}$} \\
\hline & & $\begin{array}{l}\text { Dissolved } \\
\text { Solids } \\
\text { Residue }\end{array}$ & Sulfate & Fluoride & $\begin{array}{c}\text { Total } \\
\text { Phosphorous } \\
\text { (as P) }\end{array}$ & $\begin{array}{l}\text { Total } \\
\text { Nitrogen } \\
(\text { as N) }\end{array}$ & $\begin{array}{l}\text { Radium- } \\
\text { 2261/ }\end{array}$ \\
\hline$c_{1}$ & $\begin{array}{l}\text { Deep Creek } \\
\text { natural flow }\end{array}$ & 100 & 7.8 & 0.2 & 0.10 & 0.81 & $\underline{2} / 0.06$ \\
\hline & $\begin{array}{l}\text { Effluent from mining- } \\
\text { beneficiation } \\
\text { operations (esti- } \\
\text { mated from table 22) }\end{array}$ & 334 & 151 & 2.3 & 1.9 & 6.9 & .3 \\
\hline \multirow[t]{2}{*}{$c_{3}$} & $\begin{array}{l}\text { Estimated Deep } \\
\text { Creek mixed flow }\end{array}$ & 179 & 56 & .9 & .71 & 2.9 & .14 \\
\hline & $\begin{array}{l}\text { Drinking Water } \underline{3} \text { / } \\
\text { Standard }\end{array}$ & 500 & 250 & 1.8 & - & 10 & 5 \\
\hline$\frac{\frac{1}{2} /}{3} /$ & $\begin{array}{l}\text { Concentrations are in } p \\
\text { Median concentration is } \\
\text { Dissolved solids residu } \\
\text { (U.S. Environmental Pro } \\
\text { standard for fluoride i } \\
68.7^{\circ} \mathrm{F} \text { (U.S. Environmen } \\
\text { given is for nitrate ni } \\
\text { drinking water standard } \\
\text { Agency (1976). }\end{array}$ & $\begin{array}{l}\text { cocurles pe } \\
\text { used rather } \\
\text { and sulfat } \\
\text { ection agen } \\
\text { given for } \\
\text { al Protecti } \\
\text { rogen becau } \\
\text { for Radium- }\end{array}$ & $\begin{array}{l}r \text { liter. } \\
\text { than ave } \\
\text { e are sec } \\
\text { cy, 1977) } \\
\text { an averag } \\
\text { on Agency } \\
\text { se none h } \\
226 \text { is } \mathrm{fr}\end{array}$ & $\begin{array}{l}\text { rage. } \\
\text { ondary drit } \\
\text { The prit } \\
\text { annual a } \\
\text { las been se } \\
\text { om the U.S }\end{array}$ & $\begin{array}{l}\text { nking water s } \\
\text { mary drinking } \\
\text { ir temperatur } \\
\text { The drinking } \\
\text { t for total } n \\
\text { - Environment }\end{array}$ & $\begin{array}{l}\text { tandards } \\
\text { water. } \\
\text { e of } \\
\text { water stan } \\
\text { itrogen. } \\
\text { al Protect }\end{array}$ & $\begin{array}{l}\text { ndard } \\
\text { The } \\
\text { tion }\end{array}$ \\
\hline
\end{tabular}


Analyses of water from phosphatic clayey waste settling ponds in the phosphate industry operation in Hamilton County showed radium-226 concentrations of 2.5 and $5.3 \mathrm{piC} / \mathrm{L}$ (Irwin and Hutchinson, 1976, p. 12). Comparison of concentrations in untreated and acidified split samples (Irwin and Hutchinson, 1976, p. 14) Indicates that samples such as these that had received acidification before filtration may produce unrealistically high values as the result of leaching suspended material.

Even though average radium-226 concentrations in the effluent probably would not greatly exceed those in natural streamflow, accidental discharges such as might result from failure of phosphatic clayey waste settling pond dams or dikes could cause the stream water to have higher concentrations for a perlod of time following the release, providing the phosphatic clayey wastes contained high radium-226 concentrations. For example, a phosphatic clayey waste settling pond failure in central Florida caused a release of over 16.5 curies of radium-226 to the Peace River (U. S. Environmental Protection Agency, 1974, p. 39). The river water contained over twice the then current U. S. Public Health Service Drinking Water Standard for radioactivity a year and a half after the pond failure, owing to continuous leaching of radium from the sediment deposited in the river. Other effects of such releases would likely be high turbidity, deoxygenation of stream waters, and deposition of clayey sediments on the stream bottom.

Adsorption and exchange of cations and anions by stream sediments and sediment-water interaction would be expected to have some stabilizing effect upon streamflow chemistry, (Kennedy, 1965). This effect would perhaps not be observable, being masked in Deep Creek because of the expected variability in streamflow quality in that stream.

\section{Effects on Ground Water}

Potentiometric Surfaces

Surficial Aquifer

Dewatering operations that accompany the excavation of the phosphate ore would lower the water table in the surficial aquifer locally during the period of active excavation. However, once excavation ceases in an area and the area is backfilled, the water table would recover to a new position that would be controlled by the changed topography and permeability of the surficial aquifer.

Topography of the currently mostly flat and featureless National Forest surface would be modified by the mining activities. Locally, post-mining relief might be increased by as much as a few tens of feet, if mining were to be done as it is being done now (1977) in Hamilton County. Because the configuration of the water table is generally a subdued replica of the topography of an area, the post-mining water 
table locally would have greater relief. The magnitude of the change in configuration from that of the nearly flat and relief-free water table existing today would depend largely on the amount of change in relief of the land surface. At present, the water table is at or within a few feet of the land surface throughout much of the forest. After mining, depth to the water table might be increased to perhaps 10 to 20 feet below land surface beneath areas of mounds or ridges left by the mining processes. In those areas where excavation and backfill operations leave the land surface depressed from what it is today, the depth to the water table would probably decrease from what it is now, at least during part of the year.

\section{The resulting reliaf of the water table would depend, letet In} part, on the permeability of redeposited material. Where permeability of the mounded materials was low, the water table would stand at higher elevations than where permeability was greater.

The modified water table would tend to fluctuate in response to climatic conditions over a wider range than it had before disturbance. The magnitude of water-table fluctuations would be greatest beneath the mounds and ridges and least in the depressions. It is difficult to quantity the range of fluctuations without knowledge of the new permeability distribution that would result within the surficial aquifer from the mining operations. However, the seasonal range in the new mound and ridge areas might be two or more times the few feet of fluctuation that occurs today throughout most of the comparatively flat forest.

Hawthorn Confining Unit

The potentiometric surfaces of the various strata comprising the Hawthorn confining unit would probably be changed somewhat in response to changes in the configuration of the water table and in the potentiometric surface of the Floridan aquifer. Any local changes in Hawthorn water levels would not appreciably affect water supplies or streamflow.

\section{Floridan Aquifer}

The hypothetical plan (Cole, 1977) for the mining of phosphate deposits in the National Forest calls for the use of wells tapping the Floridan aquifer to supply part of the required water. According to the plan, 8,200 gal/min would be pumped from the Floridan for six months before the start of actual mining at each of the two potential mining units. After startup, withdrawals of makeup water would average about $5,100 \mathrm{gal} / \mathrm{min}$ for the duration of the mining. Accordingly, evaluations were made of the lowering of the Floridan potentiometric surface that would result from these rates of pumping. 
Certain assumptions were made in calculating the pumping effects. First, it was assumed that the group of three wells proposed by Cole for each mining unit would be located at the respective plant sites (fig. 39). Secondly, the distances between the wells in each group were assumed small enough so that for purposes of calculating regional drawdowns, pumpage from the three wells could be considered as being from one well. Two pumping centers, one at each potential plant site, were used in making calculations. Lastly, a makeup water withdrawal of $6,000 \mathrm{gal} / \mathrm{min}$ per mining unit was used in the analysis even though the average demand was estimated at about $5,100 \mathrm{gal} / \mathrm{min}$. Use of the higher rate enables a conservative determination of maximum drawdown.

\section{Drawdowns were evaluated by use of leaky-aquifer formulas as} described by Ferris and others (1962, p. 112) and Lohman (1972, p. 30), and by use of the Theis nonequilibrium formula described by Lohman (1972, p. 15). As indicated earlier, the leakance determined from the Floridan aquifer test made in the forest was unrealistically high if applied to the confining beds immediately overlying the Floridan. Accordingly, a more realistic upper-limit value for leakance, considering overlying beds only, was determined as follows. The average hydraulic conductivity of Hawthorn members $D$ and $E$, the confining beds immediately overlying the Floridan, was estimated on the basis of a leakage rate of $1 \mathrm{in} / \mathrm{yr}$ (based on outflow analysis which showed leakage to be less than $1 \mathrm{in} / \mathrm{yr}$ ) and the prevailing vertical hydraulic gradient of 1 . The leakance, $\mathrm{K}^{\prime} / \mathrm{b}^{-}$(hydraulic conductivity of confining bed $\div$thickness of confining bed), was determined to be $5.7 \times 10^{-6}$ day $^{-1}$. A transmissivity of $66,000 \mathrm{ft}^{2} /$ day and a storage coefficient of $1 \times 10^{-4}$ were used in the computations of drawdown.

Figure 40 shows the drawdowns at various distances that would result from pumpage of $8,200 \mathrm{gal} / \mathrm{min}$ for 180 days, assuming the aquifer were infinite in extent and everywhere had the same hydraulic properties, and assuming a leakance of $5.7 \times 10^{-6}$ day. Figure 41 shows drawdowns for the nonleaky aquifer situation.

The Floridan aquifer is largely unconfined in the karst area southwest of a line from White Springs to Lake City (fig. 39). The change from confined to unconfined conditions results in less drawdown than predicted by the infinite-aquifer analysis, particularly in the direction of the unconfined part of the aquifer. The unconfined part of the aquifer would function as a quasi-constant-head source because of the change to a water-table storage coefficient and direct replenishment of ground water there by rainfa11 and streamflow infiltration. Adjustments to the drawdowns can be made by emplacing a constant-head boundary along the line of contact between the confined and unconfined parts of the aquifer. However, the resulting adjustments would probably be too great because the unconfined part of the aquifer most likely would not be fully effective as a recharge source along the contact line. If a fully effective constant-head boundary were considered, the drawdown at 


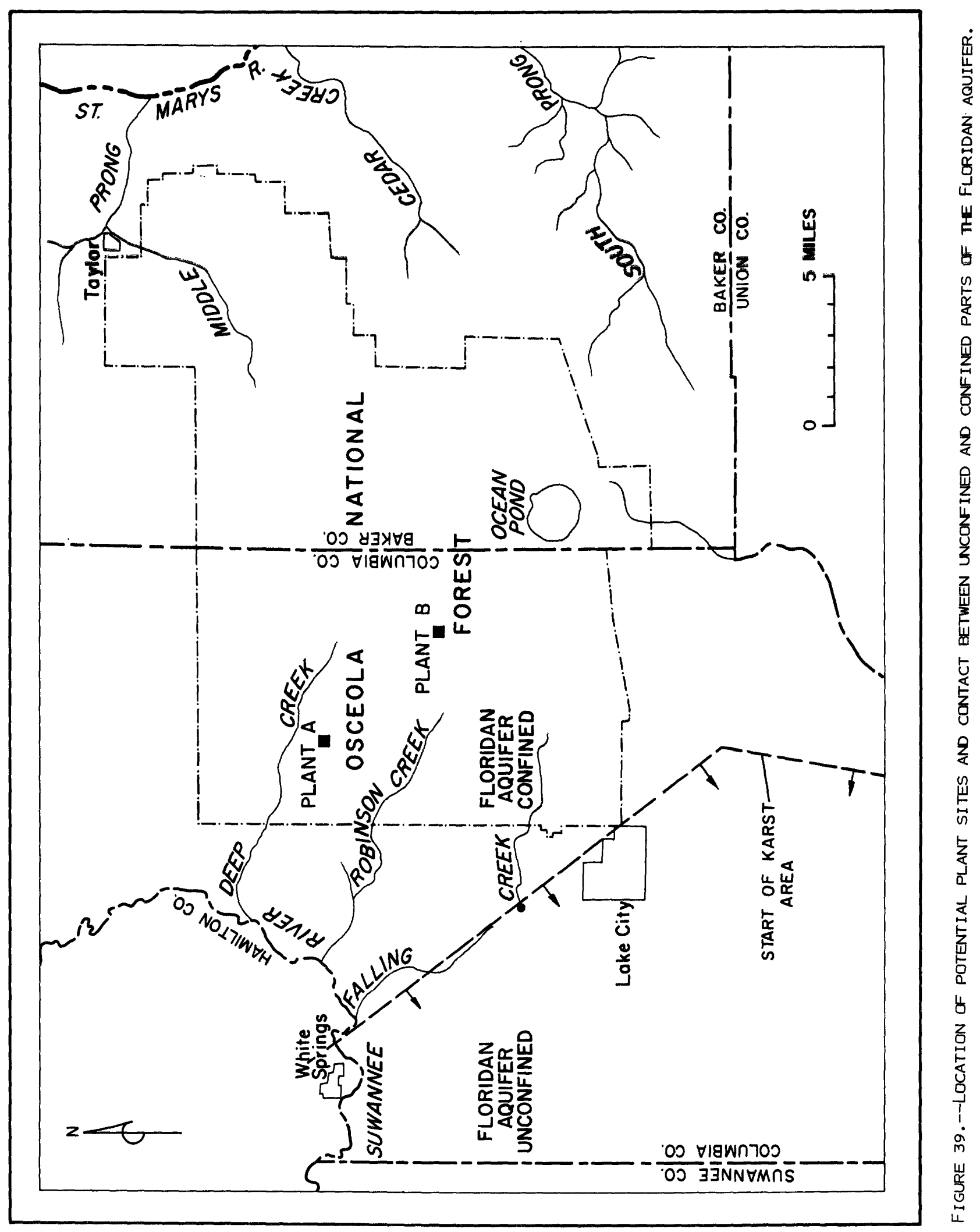




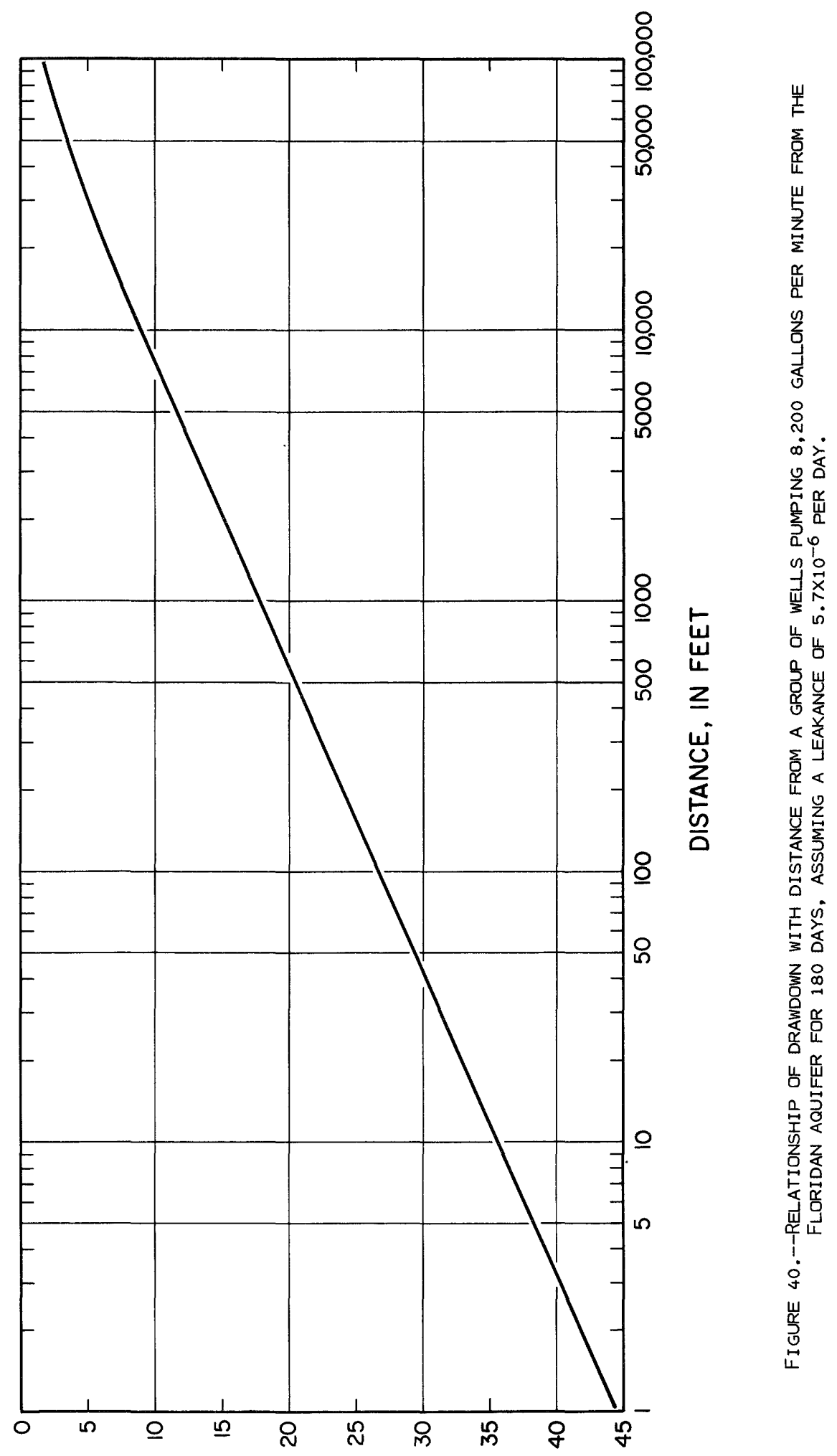

1 $\exists \exists \exists \mathrm{NI}$ 'NMOOMEYO 


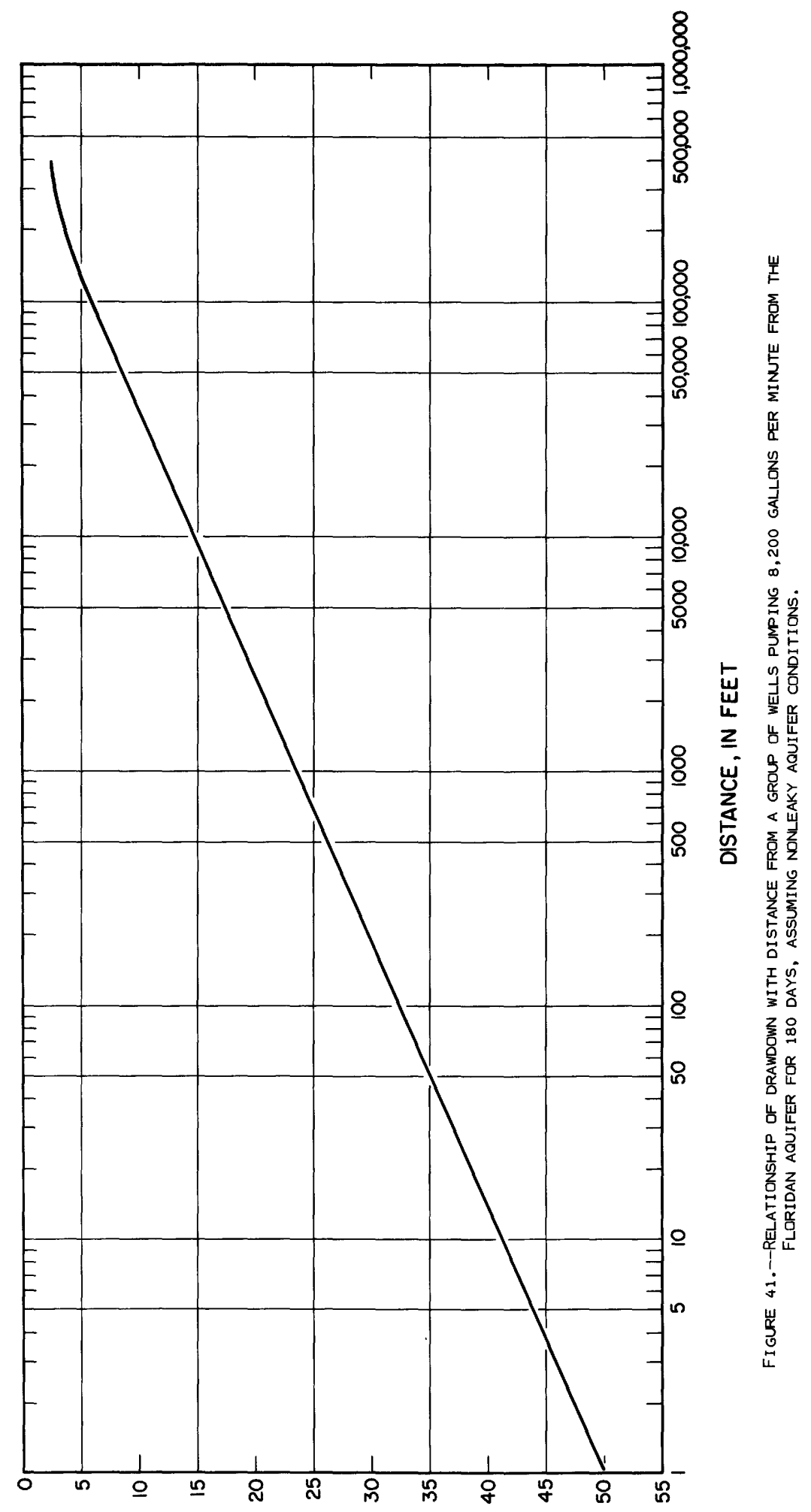

13ヨ」 NI ' NMOOMEYO 
the boundary theoretically would be zero. Thus, the actual drawdown at the line of contact and in the area beyond the line would be between zero and the drawdown based on the nonleaky aquifer analysis. Both drawdown values are shown in the following calculations in order to indicate the probable limits.

Considering both hypothetical mining units, that is, two pumping centers each pumping $8,200 \mathrm{gal} / \mathrm{min}$ simultaneously for 180 days, drawdowns at various points due to the pumpage from both centers would be as follows, if the aquifer had a leakance of $5.7 \times 10^{-6} \mathrm{day}^{-1}$ :

\begin{tabular}{cc} 
Drawdown (ft) \\
Without boundary & With boundary \\
\cline { 2 - 2 } 50 & 46 \\
15 & 12 \\
5 & 0 \\
6 & 0 \\
4 & 2
\end{tabular}

$\begin{array}{ll}\text { 1. Proposed pumping centers } & 50 \\ \text { 2. Midway between centers } & 15 \\ \text { 3. White Springs } & 5 \\ \text { 4. Center of Lake City } & 6 \\ \text { 5. Taylor } & 4 \\ & \end{array}$

Drawdown ( $f t$ )
Without boundary $\quad$ With boundary

1. Proposed pumping centers

61

2. Midway between centers

27

15

3. White Springs

14

4. Center of Lake City

16

5. Taylor

12

3

Figure 42 shows the variation of steady-state drawdown with distance, assuming pumpage of $6,000 \mathrm{gal} / \mathrm{min}$ from an infinite aquifer having a leakance of $5.7 \times 10^{-6} \mathrm{day}^{-1}$. Again considering both pumping centers, the steady-state drawdown for the same points as above would be as follows:

Drawdown ( $f t)$

Without boundary

With boundary

1. Proposed pumping centers

36

33

2. Midway between centers

3. White springs

12

8

4. Center of Lake City

5. Taylor 


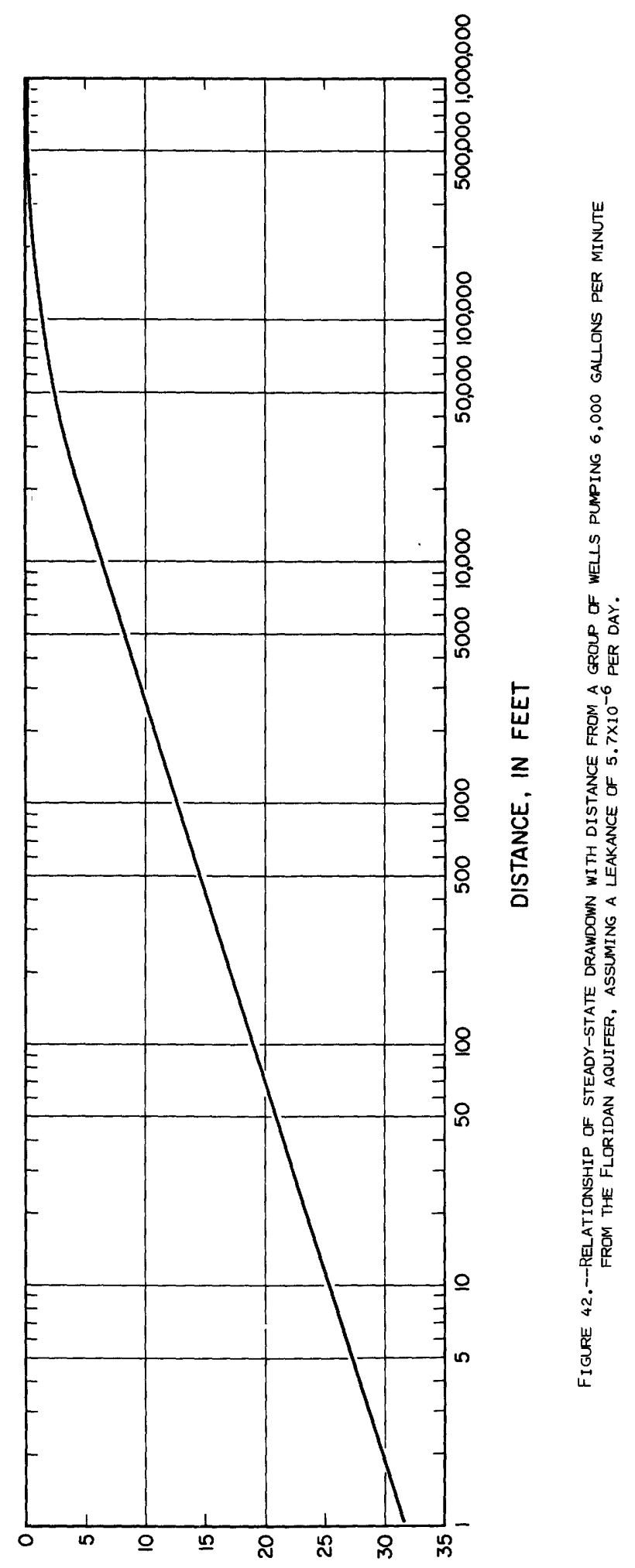

L $\exists \exists \exists \mathrm{NI}$ 'NMOOMEYO 
If the aquifer were nonleaky, the drawdowns after 11,000 days (about 30 yrs) of pumping would be as shown on figure 43, and for the points of interest would be:

\section{Drawdown ( $f t)$ Without boundary}

56

32

22

24

21
With boundary

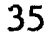

11

3

The drawdowns predicted above were based on hydrogeologic conditions at the aquifer-test site which is near potential plant A. However, hydrogeologic conditions overall at potential plant B site probably are not so different as to result in drawdowns markedly different from those estimated above.

Considerable ranges in drawdowns resulted, as shown above, from the application of various aquifer models. The model that approximates the actual situation most closely is that of a nonleaky aquifer bounded by sources of recharge that include the Suwannee River, Falling Creek, and the karst area to the southwest of the forest. Therefore, the respective drawdowns predicted with the nonleaky bounded model most 1ikely best represent the magnitude of drawdowns to be expected.

Drawdown caused by the assumed pumpage would depress the potentiometric surface of the Floridan aquifer within the forest. As stated earlier, ground water in the Floridan leaves the forest predominantly in a northeast to easterly direction toward the Atlantic Coast. The assumed pumpage would be derived from a combination of sources that would include: capture of part of the northeasterly discharge; part of the recharge resulting from the sinkhole capture of Falling Creek; capture of part of the ground-water discharge to the Suwannee River and induced inflow from the river; induced inflow from the karst area; natural and induced vertical leakage; and changes in storage within the limits of the cone of depression.

Part of the capture of ground-water flow to the Suwannee River might result in reduced springflow. Discharge of springs on the Suwannee River has varied over the years, as typified by the discharge of White Springs which has ranged from 0 to $72 \mathrm{ft}^{3} / \mathrm{s}$, based on measurements made at irregular intervals from 1907 to 1977 (J. C. Rosenau, written commun., 1977).

The effect of pumpage on the flow of the Suwannee River most 1ikely would be small. The potentially reduced contribution from spring discharge would be more than offset by the additional streamflow of Deep Creek. In fact, the net effect might be to increase the flow of the 


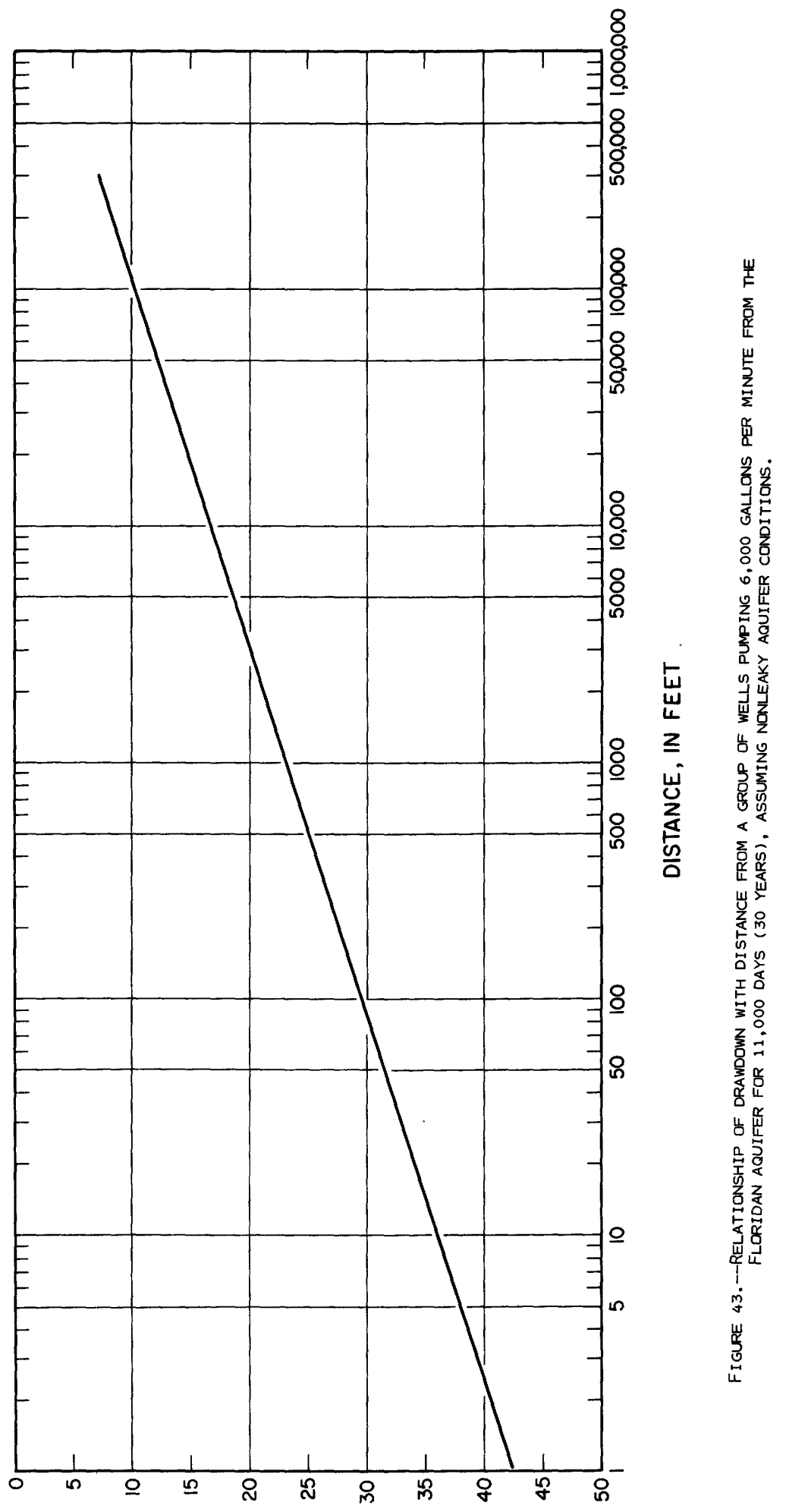

1 $3 \exists \unlhd$ NI 'NMOQMVYO 
Suwannee River below White Springs in that the mining area releases would incorporate ground waters that ordinarily would not have discharged to the Suwannee RIver, either directly or through its tributaries.

The decline of the Floridan potentiometric surface resulting from the proposed pumpage would increase leakage to the Floridan aquifer. The increase in leakage would be greatest near the pumping centers where drawdowns were at a maximum and would diminish away from the centers where drawdowns were less. For example, taking concentric bands around a pumping center of $100-, 1,000-$, and 10,000-feet outer radius, upward limits of the average rates of leakage (natural and induced) that would result from a pumpage of $6,000 \mathrm{gal} / \mathrm{min}$ would be distributed as follows (given a leakance of $5.7 \times 10^{-6} \mathrm{day}^{-1}$ based on $1 \mathrm{in} / \mathrm{yr}$ natural leakage):

$$
\begin{array}{rc}
\text { Outer ring radius (ft) } & \text { Average leakage (in/yr) } \\
100 & 1.55 \\
1,000 & 1.40 \\
10,000 & 1.24
\end{array}
$$

Beyond 10,000 feet, the difference between the leakage rate under the given pumping conditions and that under natural conditions would be 16 percent or 1ess.

\section{Ground-Water Quality}

\section{$\underline{\text { Surficial Aquifer }}$}

Phosphate industry activities could affect the quality of water in the surfictal aquifer in areas of mining and in areas where the hydraulic system leaks water to the underlying aquifer. Aeration of materials during excavation and backfilling would change the pre-mining geochemical equilibrium conditions, thereby increasing or decreasing concentrations in ground water of certain chemical constituents. Leachate, if present, from the phosphatic clayey waste settling ponds or the hydraulic ditches could introduce constituents presently absent in surficial aquifer water or enrich concentrations of those already there. Any leachate not captured by the hydraulic system would eventually migrate to a stream or percolate downward to underlying strata.

\section{Hawthorn Confining Untt}

Quality of water in the Hawthorn confining unit should be less affected than that of the surficial aquifer. Strata making up the Hawthorn confining unit would not be disturbed by the mining operations and would continue to act as a pemeability boundary. If leachate from the hydraulic system is like effluent currently discharged to streams, it would be difficult to distingulsh from naturally-occurring water in the Hawthorn if percolation should occur. 
Floridan Aquifer

Upward Movement of Poor Quality Water: The quality of water in the uppermost part of the Floridan aquifer beneath the forest was defined in some detail during this investigation. However, the quality of water in the deeper parts of the aquifer could only be estimated based on extrapolation of water-quality data from other areas and on a tenuous interpretation of geophysical data from local oil-test wells. These data suggest that water in the lower part of the Floridan is more mineralized-by about an order of magnitude--than that in the upper part. The greater mineralization of the lower Floridan water is due largely to sulfate ions from the dissolution of anyhydrite and (or) gypsum. Sulfate concentration probably increases abruptly rather than gradually, based on depth-profile sampling of wells at Valdosta, Georgia, (H. E. Gill, written commun., 1977); Quincy, Florida (C. A. Pascale, written commun., 1977), and Jacksonville, Florida (Leve and Goolsby, 1967, p. 21). The depth at which high-sulfate water is encountered beneath the forest probably differs from place to place. In the area of the potential phosphate industry operations, the high-sulfate (about $1,000 \mathrm{mg} / \mathrm{L}$ ) water probably occurs at a depth between about 1,000 feet, based on data from a well at Lake City (Meyer, 1962, p. 47), and 1,250 feet (K1ein, 1975).

The large-capacity supply wells required for the potential phosphate industry operations most likely would penetrate several hundred feet of the Floridan aquifer. These wells probably would pump water having a quality that reflects the blending of upper Floridan water, which is comparatively low in dissolved solids and sulfate, with lower Floridan water of much higher sulfate and dissolved solids concentrations. Concentrations of sulfate and of dissolved solids in the blended water that would be discharged from these wells cannot be estimated from available information. However, chemical analyses of water from Floridan wells in the four-county area (Healy, 1977; written commun., R. Krause, 1977) indicates that genera1ly those wells tapping several hundred feet or more of aquifer yield water with sulfate concentrations that are at least several times greater than those in water from wells tapping only the upper few hundred feet. The difference in dissolved solids concentration is not as marked nor as consistent as that for sulfate.

The quality of water pumped from the Floridan aquifer would influence considerably the quality of water discharged from the phosphate industry operations to streams. The possible upward movement by leakage of high-sulfate water from depths of about 1,000 feet in the aquifer would be confined to the immediate vicinity of the potential phosphate industry wells, so long as pumping continued. Once pumping were terminated any water having a high sulfate content that had moved up to higher strata would migrate in the direction dictated by the hydraulic gradients prevailing in the area at that time. 
The possibility of upward migration of very saline waters (dissolved solids $10,000-35,000 \mathrm{mg} / \mathrm{L}$ ) in response to the reduction in potentiometric head appears slight. Both the current freshwater head of the Floridan and geophysical data from oil-test wells suggest that beneath the forest the aquifer does not contain very saline water even near its base. Any very saline water in strata beneath the Floridan aquifer would be restricted from moving upward into the aquifer by the poor hydraulic interconnection of the Floridan with the deeper strata.

Introduction of Contaminants by Way of Sinkholes: Sinkholes occur to the west of the National Forest in the valley of Falling Creek but none are known to occur within the forest. Any contaminants carried by Falling Creek would move into the Floridan aquifer with the streamflow where the creek disappears into a sinkhole. Parts of upper Falling Creek basin are included in the potential mining plan; therefore, the introduction of contaminants from the phosphate industry operations to the Floridan aquifer by way of Falling Creek is probable unless runoff from the upper part of the basin is carefully controlled.

Downward Movement of Potential Leachate: The chemical quality of water that would be involved in the hydraulic system of the potential phosphate industry operations would probably be like that of naturallyoccurring ground water in the Hawthorn confining unit, except for sulfate, fluoride, nitrogen, and phosphorus concentrations. Therefore, any leachate that might move through the Hawthorn confining unit would have little influence on deeper ground-water quality. Of these constituents, sulfate, and nitrogen would exhibit the greatest influence. Sulfate would tend to move most conservatively with leachate through the surficial aquifer and Hawthorn confining unit. Phosphorus would be precipitated and (or) adsorbed, especially on the clay minerals of the Hawthorn B member. Fluoride and ammonia nitrogen concentration would be attenuated to some degree through adsorption on clay minerals, or in the case of fluoride, would be precipitated as fluorite (Toler, 1967, p. 41).

Any leachate that were to enter the Floridan aquifer by vertical leakage, would be greatly dispersed by the lateral movement of water in the aquifer, thus decreasing the potential for a major change in the aquifer's water quality. Wells pumping from the Floridan aquifer would probably produce water from several zones and any sulfate-rich leachate water encountered by a well would be blended with other waters.

\section{Potential for Sinkhole Development}

Sinkholes develop when a portion of the roof of an underground solution opening developed in carbonate rock collapses in response. to natural or artificial loading or because of reduced strength of the roof over the opening. Increased effective loads may be added by construction 
on the land surface, may result from the withdrawal of support from beneath the roof as a result of decline in ground-water levels (Newton, 1976 , p. 2), or may be caused by the removal by stoping of the plug in old sinkholes. Water-level declines may be either natural or created by withdrawals from wells. Areas most susceptible to sinkhole development are those where a thin, poorly consolidated layer of material overlies a solution-riddled carbonate-rock aquifer. Sinkhole development is most common, but is not limited to, areas where water-table conditions exist in a carbonate-rock aquifer.

No sinkholes have been definitely identified within Osceola National Forest by examination of aerial photographs and topographic maps of the forest, and visual reconnaissance from a low-flying plane. However, the circular shape of Ocean Pond, two small circular lakes, and a few swampy areas within the forest suggest a solution-related origin for these features.

Initial withdrawals of $8,200 \mathrm{gal} / \mathrm{min}$ at each potential phosphate plant would lower Floridan water levels an estimated maximum of 61 feet at the apex of the cone of depression created by this pumping. As a result of this withdrawal an effective additional load of about 3,800 lbs/ft ${ }^{2}$ would be added to the roof of a hypothetical solution opening, an increase of 30 to 40 percent above the natural static load. This additional stress would of course be applicable only to the area near the apex of the cone of depression, and the probability of sinkhole development would be greatest there. Elsewhere the increase in load would decrease from the above value in direct proportion to the reduction in drawdown.

Some additional stress would be created by construction of a plant or by the stockpiling of ore, tailings and phosphatic clayey wastes over the roof of an incipient sinkhole, if any were present. The stress resulting from the stockpiling of wastes could be alleviated if tailings were returned to mined-out areas. The net result would be a slight decrease in load in those mined-out areas due to removal of the phosphate ore.

Cyclical reductions in artesian pressure in a highly permeable carbonate-rock aquifer at the base of a clay plug in an ancient sinkhole can cause spalling of layers of clay from the plug as the pore pressure in the clay becomes greater than in the adjacent aquifer. This stoping process gradually reduces the thickness of the clay plug, tending to reactivate the sinkhole. 
Osceola National Forest is a moderately flat, poorly drained area covering 245 square miles in Columbia and Baker Counties, Florida, ranging in altitude from less than 100 to slightly more than 215 feet. The forest vegetation consists of 70 percent pine palmetto flatwoods and 30 percent hardwood swamps and irregular to circular-shaped cypress bays. The climate of the area is subtropical, with an average rainfall of about 53 to 54 inches per year, of which about 39 to 40 inches is returned to the atmosphere by evapotranspiration and 11 to 13 inches becomes surface-water runoff. The calculated water budget for the forest shows a residual from 0 to 4 inches of water per year available for recharge to the Floridan aquifer.

Small sluggish streams drain 55 percent of the forest eastward to the St. Marys River and 45 percent of the forest westward to the Suwannee River. Drainage eastward is primarily by Middle Prong St. Marys River, westward by Deep and Robinson Creeks which empty directly into the Suwannee River and by Falling Creek which flows into a sinkhole 4 miles west of the forest. Average annual discharge of the forest streams is slightly less than $1.0 \mathrm{ft}^{3} / \mathrm{s}$ per $\mathrm{mi}^{2}$. Surface-water quality is areally and temporally similar throughout the forest, and at times of low flow resembles that of shallow ground water because it consists largely of ground-water discharge. Surface waters are acidic, have low inorganicion and suspended-sediment concentrations, and have organic constituent concentrations about equal to inorganic-ion concentrations.

The forest is underlain by a minimum of 2,500 feet of Atlantic Coastal Plain sediments of Early Cretaceous to Holocene age, which were deposited on Paleozoic rocks on the northeast flank of the anticlinal Peninsular Arch. Phosphate of both the land-pebble and primary types occurs in the Hawthorn Formation of middle Miocene age in the forest within a few tens of feet of the surface. The oldest formation penetrated by test drilling during this investigation is the Ocala Limestone of late Eocene age, which ranges in altitude in the forest from 50 feet to minus 270 feet. The Ocala is composed of an upper white soft calcarenite succeeded downward by gray crystalline fossiliferous limestone. Both rock types are highly porous and permeable.

The Ocala Limestone is unconformably overlain by the Hawthorn Formation of middle Miocene age, which, where penetrated by test holes, ranges in thickness from about 70 to 330 feet in the forest area. Five informally designated members have been delineated within the Hawthorn. From oldest to youngest, these are: 1) member E, a dark-brown limestone and calcareous sandstone unit containing fossils and a vuggy porosity; 2) member $D$, consisting of complexly interbedded sandstone, limestone, and clay, with traces of phosphate and fossiliferous material; 3) member $C$, a fine- to medium-grained green-gray sand; 4) member B, a massive 
green clay which contains considerable limestone in the eastern half of the forest, and; 5) member $A$, a phosphatic sand and phosphatic argillaceous limestone unit whose beds are highly variable in thickness and extent, and which contain scarce macro- and microfossils. Post-Miocene rocks, where penetrated by test holes consist of 6 to 54 feet of sand and clayey sand, both containing much woody organic material, overlying the Hawthorn Formation.

The ground-water system beneath the forest consists of: 1) the surficial aquifer, which includes all post-Miocene rocks and member $A$ of the Hawthorn Formation; 2) the Hawthorn confining unit, consisting of members $B$ through $E$ of the Hawthorn Formation, and; 3) the Floridan aquifer, consisting of 1,000 feet or more of generally highly permeable carbonate rocks of Paleocene to late Eocene age. Water in the surficial aquifer is under unconfined or water-table conditions; the Hawthorn confining unit creates artesian conditions in the underlying Floridan aquifer. A downward hydraulic gradient exists from the surficial aquifer through the Hawthorn confining unit to the Floridan aquifer, indicating a potential for downward leakage. The leakage is controlled by the low permeability of some beds in the Hawthorn confining unit. Ground-water flow calculations show leakage is less than one inch per year.

The water table of the surficial aquifer lies at or near land surface and responds directly and rapidly to rainfall. The potentiometric surface of member $C$ of the Hawthorn confining unit is about 40 feet below that of the surficial aquifer; the Floridan's potentiometric surface is 80 to 90 feet below the water table. Water levels in both the Floridan and member $C$ vary with evapotranspiration and rainfall. Floridan water levels also reflect stage fluctuations of the Suwannee River to the west of the forest.

Ground water discharges from the surficial aquifer to evapotranspiration, by lateral movement to surface-water bodies, and by downward percolation to the Floridan aquifer. The quality of the water in the upper surficial aquifer closely resembles that of the forest streams. The deeper permeable units contain water of the calcium magnesium bicarbonate type, and the amount of mineralization of the water increases with depth through the Hawthorn confining unit. Mineralization of the ground water in the upper part of the Floridan is slightly less than that of water in the Hawthorn confining unit.

Aquifer tests show that member $C$, the most permeable part of the Hawthorn confining unit, has a transmissivity of $15 \mathrm{ft}^{2} / \mathrm{d}$, a storage coefficient of $1.2 \times 10^{-4}$, and a hydraulic conductivity of $0.75 \mathrm{ft} / \mathrm{d}--$ a value that indicates a poor aquifer. The upper part of the Floridan aquifer has a transmissivity of $33,000 \mathrm{ft}^{2} / \mathrm{d}$, based on aquifer test results. This figure is probably low because only the upper part of the aquifer was penetrated by the wells used for aquifer testing. Based on avallable data for the Floridan from areas surrounding the forest, the actual transmissivity of the aquifer is estimated to be $66,000 \mathrm{ft}^{2} / \mathrm{d}$. 
A potential phosphate mining plan for the Osceola National Forest consists of two mining areas and beneficiation plants (but no chemical plant) located in the western half of the forest. Sources, uses, and quality requirements of water for these operations are similar to those of other phosphate mining areas in Florida. An estimated pumpage from the Floridan aquifer of $8,200 \mathrm{gal} / \mathrm{min}$ would be needed at each mining unit for six months prior to startup, and about 5,100 gal/min would be required after startup. Any excess water from the phosphate operations would be discharged into existing streams, with 2,300 acres per mining unit left as standing water bodies after mining operations cease.

A phosphate industry mining, beneficiation, and chemical processing complex similar to that possibly to be proposed for Osceola National Forest (except for the chemical plant) has existed since 1965 in Hamilton County, to the west of the forest in a physical setting similar to that of the forest. In this existing mining area, natural runoff is decreased because considerable areas of standing water bodies susceptible to evaporation have been created by mining activities. This decrease is offset by the addition of water pumped from the Floridan aquifer to land surface. The release of water by artificial control from the phosphate complex alters the flow characteristics of the receiving stream(s). Hunter and Swift Creeks, the two streams most affected by phosphate operations, show notably higher concentrations of phosphorous, nitrogen, fluoride, sulfate, suspended sediment, and dissolved solids than do Rocky and Roaring Creeks, nearby Hamilton County streams which apparently do not reflect the effects of the phosphate mining complex. The present day phosphate industry operations have apparently had effects on the permeability, water levels, and water quality of the surficial aquifer. These operations have had less effect on the Hawthorn confining unit, and have apparently affected the Floridan aquifer only by lowering its potentiometric surface.

Phosphate mining in the forest would be expected to produce effects similar to those observed in the present day Hamilton County mining and beneficiation operation. The flow characteristics of the streams draining the forest would be changed due to shifting of basin divides and an interbasin transfer of water, primarily to Deep Creek from other basins. But except for Deep Creek (assumed likely to be the receiving stream for the entire effluent from the phosphate industry operations) the overall effect on streamflow would be less than 10 percent of the average annual discharge. Average flow of Deep Creek would be increased about 40 percent by phosphate industry releases consisting largely of water added to the hydraulic system of the phosphate mining complex from pumpage of the Floridan aquifer. In practice, the effect would be most notable during low-flow periods and at those particular times when releases from the hydraulic system are withheld. The effluent-receiving stream(s) would have average concentrations of dissolved solids, sulfate, phosphorous, nitrogen, and fluoride that are higher than under natural conditions. Suspended sediment concentrations would increase in all the 
streams draining the forest because of the land-clearing and excavation activities and the draining of swampland. However, the increased concentrations in all the streams would not exceed the U. S. Environmental Protection Agency recommended maximum contaminant levels for drinking water, except possibly for fluoride or nitrate. Concentrations of radium-226 and other radioactive constituents would not be increased much above natural levels in any of the receiving waters.

As a result of mining, the water table of the surficial aquifer would become a subdued replica of the modified topographic surface. Changes in the quality of water in the surficial aquifer would be local. Effects on the water quality and hydrologic characteristics of the Hawthorn confining unit would be less than those on the surficial aquifer. Any effects on the surficial aquifer and Hawthorn confining unit would be felt primarily in the vicinity of the phosphate industry operations.

The lowering of the Floridan potentiometric surface would be less than 5 feet at Lake City, White Springs, and Taylor, the nearest sources of public supply, and unnoticable beyond these points. Although the lowered Floridan potentiometric surface might reduce spring flow to the Suwannee River somewhat, the average flow of the river would most likely be unaffected. No appreciable changes in the quality of the water in the Floridan aquifer are expected, providing plant effluent was not discharged to Falling Creek which recharges the Floridan through a sinkhole 4 miles beyond the western boundary of the forest.

No sinkholes were found in the forest. Additional stresses will be created by mining and beneficiation activities, but it is not known whether these stresses will be great enough to create sinkholes or to reactivate ancient sinkholes, if any are present. 


\section{REFERENCES}

Applin, P. L., 1951, Preliminary report on buried pre-Mesozoic rocks in Florida and adjacent States: U.S. Geol. Survey Circ. 91, 28 p.

Applin, P. L., and Applin, E. R., 1944, Regional subsurface stratigraphy and structure of Florida and southern Georgia: Am. Assoc. Petroleum Geologists Bul1. v. 28, no. 12, p. 1673-1753.

1967, The Gulf Series in the subsurface in northern Florida and southern Georgia: U.S. Geol. Survey Prof. Paper 524-G, 35 p.

Avers, P. E., and Bracy, K. C., no date, Soils and physiography of the Osceola National Forest: U.S. Dept. Agriculture, Forest Service, $94 \mathrm{p}$.

Barnes, H. H., Jr., and Golden, H. G., 1966, Magnitude and frequency of floods in the United States: U.S. Geol. Survey Water-Supply Paper 1674, part 2-B, 409 p.

Beck, K. C., Reuter, J. N., and Perdue, E. M., 1974, Organic and inorganic geochemistry of some coastal plain rivers of the southeastern United States: Geochimica et Cosmochimica Acta, v. 38, p. 341-364.

Bentley, C. B., 1977, Aquifer test analyses for the Floridan aquifer in Flagler, Putnam, and St. Johns Counties, Florida: U.S. Geol. Survey Water-Resources Inv. 77-36, 48 p.

Black, A. P., and Brown, Eugene, 1951, Chemical character of Florida's waters-1951: Florida State Board Conserv., Div. Water Survey and Research, Paper 6, 119 p.

British Sulphur Corporation, 1961, World survey of phosphate deposits: London, British Sulphur Corporation, Ltd., v. 2, Canada and eastern U.S.A., 416 p.

Brown, Eugene, Skougstad, M. W., and Fishman, M. J., 1970, Methods for collection and analysis of water samples for dissolved minerals and gases: U.S. Geol. Survey Techniques of Water-Resources Inv., Book 5, chap. Al, 160 p.

Chen, C. S., 1965, The regional 1ithostratigraphic analysis of Paleocene and Eocene rocks of Florida: Florida Geo1. Survey Bul1. 45, 105 p.

Cole, Allen T., 1977, Water demands of two logical phosphate mining units, Osceola National Forest: Unpub. rept. prepared for U.S. Bur. Mines, Washington, D. C., 33 p.

Collins, W. D., and Howard, C. S., 1928, Chemical character of waters of Florida: U.S. Geo1. Survey Water-Supply Paper 596-G, p. 117-233.

Cooke, C. W., 1945, Geology of Florida: Florida Geol. Survey Bull. 29 $339 \mathrm{p}$.

Cooper, H. H., Jr., Kenner, W. E., and Brown, Eugene, 1953, Ground water in central and northern Florida: Florida Geol. Survey Rept. Inv. $10,37 \mathrm{p}$.

Espenshade, G. H., and Spencer, C. W., 1963, Geology of phosphate deposits of northern peninsular Florida: U.S. Geol. Survey Bu11. 1118, 115 p.

Faulkner, Glen L., 1976, Flow analysis of karst systems with well developed underground circulation; in Karst hydrology and water resources; Proc. U. S.-Yugoslavian Symposium, Dubrovnik, June 2-7, 1975, p. 6-1 to 6-28. 
Ferris, J. G., 1949, Ground water; in Wisler, C. 0., and Brater, E. F., Hydrology: New York, John Wiley \& Sons, Inc., 419 p.

Ferris, J. G., Knowles, D. B., Brown, R. H., and Stallman, R. W., 1962, Theory of aquifer tests: U.S. Geol. Survey, Water-Supply Paper 1536-E, p. 69-174.

Florida Chamber of Commerce, 1974, Directory of Florida Industries: Tallahassee, Florida Chamber of Commerce, 711 p.

Gi11, H. E., Rosenau, J. C., and others, 1975, Potentiometric surface of principal artesian-Floridan aquifer in southeastern Georgia and northeastern Florida, December 1973: U.S. Geol. Survey OpenFile Rept.

Grim, R. E., 1962, Applied clay mineralogy, New York: McGraw-Hil1, 422 p. Guimond, R. J., and Windham, S. T., 1975, Radioactivity distribution in phosphate products, by-products, effluents, and wastes: U. S. Environmental Protection Agency, Technical Note ORP/CSD-75-3, 32 p. Hantush, M. S., 1956, Analysis of data from pumping tests in leaky aquifers: Am. Geophys. Union Trans., v. 37, no. 6, p. 702-714. 1960, Modification of the theory of leaky aquifers: Jour. Geophys. Research, v. 65, no. 11, p. 3713-3725.

Hantush, M. S., and Jacob, C. E., 1955, Nonsteady radial flow in an infinite leaky aquifer: Am. Geophys. Union Trans., v. 36, no. 1, p. $95-100$.

Healy, H. G., 1977, Public water supplies of selected municipalities in Florida, 1975: U.S. Geol. Survey Water-Resources Inv. 77-53, $309 \mathrm{p}$.

Hem, J. D., 1959, Study and interpretation of the chemical characteristics of natural water: U.S. Geol. Survey Water-Supply Paper 1473, $269 \mathrm{p}$.

Irwin, G. A., and Hutchinson, C. B., 1976, Reconnaissance water sampling for radium-226 in central and northern Florida, December 1974-March 1976: U.S. Geo1. Survey Water-Resources Inv. 76-103, 16 p.

Jacob, C. E., 1946, Radial flow in a leaky artesian aquifer: Am. Geophys. Unton Trans., v. 27, no. 2, p. 198-205.

Kaufman, M. I., 1975, The $\mathrm{pH}$ of water in Florida streams and canals: Florida Dept. Nat. Resources, Map Ser. 37, revised.

Kennedy, Vance L., 1965, Mineralogy and cation-exchange capacity of sediments from selected streams: U.S. Geol. Survey Prof. Paper 433-D, $28 \mathrm{p}$.

Klein, Howard, 1975, Depth to base of potable water in the Floridan aquifer: Florida Dept. Nat. Resources, Bur. Geology, Map Ser. 42, revised.

Kohler, M. A., Nordenson, T. J., and Baker, D. R., 1959, Evaporation maps for the United States: U.S. Weather Bur. Tech. Paper 37, $13 \mathrm{p} ., 5 \mathrm{pls}$.

Kohout, F. A., 1967, Ground water flow and the geothermal regime of the Floridan Plateau: Gulf Coast Assoc. Geol. Societies, Trans., v. 17, p. 339-535.

Lamont, W. E., McLendar, J. T., Clements, L. W., Jr., and Feld, I. L., 1975, Characterization studies of Florida phosphate slimes: U.S. Bur. Mines Rept. Inv. 8089, 24 p. 
Langbein, W. B., 1955, Hydrologic studies, in Water resources of southeastern Florida: U.S. Geol. Survey Water-Supply Paper 1255, p. 511-570.

Leach, S. D., 1977, Water use inventory in Florida, 1975: U.S. Geol. Survey Open-File Rept. 75-577, 57 p.

Leve, G. W., 1968, Reconnaissance of the ground-water resources of Baker County, Florida: Florida Board of Conserv., Div. Geol., Rept. Inv. $52,24 \mathrm{p}$.

Leve, G. W., and Goolsby, D. A., 1967, Test hole in aquifer with many water-bearing zones at Jacksonville, Florida: National Water Well Assn., Ground Water, v. 5, no. 4, p. 18-22.

Lohman, S. W., 1972, Ground-water hydraulics: U.S. Geol. Survey Prof. Paper $708,70 \mathrm{p}$.

Matson, G. C., and Sanford, Samuel, 1913, Geology and ground waters of Florida: U.S. Geo1. Survey Water-Supply Paper 319, 445 p.

Meyer, F. W., 1962, Reconnaissance of the geology and ground-water resources of Columbia County, Florida: Florida Geol. Survey Rept. Inv. $30,74 \mathrm{p}$.

Miller, J. A., 1971, Stratigraphic and structural setting of the middle Miocene Pungo River Formation of North Carolina: unpub. PH.D. dissert., Univ. North Carolina, 82 p.

Mossom, Stuart, 1926, Review of the structure and stratigraphy of Florida: Florida Geol. Survey 17th Ann. Rept., p. 174-268.

Murray, G. E., 1961, Geology of the Atlantic and Gulf Coastal Province of North America: New York, Harper and Brothers, 692 p.

Newman, S. P., and Witherspoon, P. A., 1971, Flow in multiple aquifer systems in Sea water intrusion: Aquitards in the coastal groundwater basin of Oxnard Plain, Ventural County: California Dept. of Water Res., Bul1. 63-4, p. 21-62.

Newman, J. G., 1976, Early detection and correction of sinkhole problems in Alabama, with a preliminary evaluation of remote sensing applications: Alabama Highway Dept., Bur. Research and Devel., HPR Rept. no. 76,83 p.

Parker, G. G., Ferguson, G. E., and Love, S. K., 1955, Water resources of southeastern Florida, with special reference to the geology and ground water of the Miami area: U.S. Geol. Survey Water-Supply Paper 1255, $965 \mathrm{p}$.

Pride, R. W., Meyer, F. W., and Cherry, R. N., 1966, Hydrology of the Green Swamp area in central Florida: Florida Geol. Survey Rept. Inv. $42,137 \mathrm{p}$.

Puri, H. A., 1953, Zonation of the Ocala Group in peninsular Florida [abs.]: Jour. Sed. Petrology, v. 23, p. 130.

157, Stratigraphy and zonation of the Ocala Group: Florida Geol. Survey Bull. 38, 248 p.

Puri, H. S., and Vernon, R. 0., 1964, Summary of the geology of Florida and a guidebook to the classic exposures: Florida Geol. Survey Spec. Pub. 5, 312 p.

Riggs, H. C., 1972, Low-flow investigations: U.S. Geol. Survey Techniques of Water Resources Inv., Book 4, chap. B1, 18 p. 
Riley, F. S., 1970, Analysis of borehole extensometer data from central California: Internat. Symposium on Land Subsidence, Tokyo, 1969, proceedings.

Shampine, W. J., 1975a, Dissolved solids in water from the upper part of the Floridan aquifer in Florida: Florida Dept. Nat. Resources, Bur. Geology, Map Ser. 14, revised.

$1975 \mathrm{~b}$, Hardness of water from the upper part of the Floridan aquifer in Florida: Florida Dept. Nat. Resources, Bur. Geology, Map Ser. 13, revised.

1975c, Sulfate concentration in water from the upper part of the Floridan aquifer in Florida: Florida Dept. Nat Resources, Bur. Geology, Map Ser. 15, revised.

Stringfield, V. T., 1936, Artesian water in the Floridan peninsula: U.S. Geol. Survey Water-Supply Paper 773-C, p. 115-195.

1966, Artesian water in Tertiary limestone in the southeastern

states: U.S. Geol. Survey Prof. Paper 517, 226 p.

Sweeney, J. W., 1970, The phosphate industry in the southeastern United States and its relationship to world mineral fertilizer demand:

U.S. Bur. Mines, Inf. Circ. 8459, 76 p.

Toler, L. G., 1967, Fluoride in water in the Alafia and Peace River basins, Florida: Florida Geol. Survey Rept. Inv. 46, 46 p.

U.S. Department of Agriculture, 1976, Interim Report, northeast Gulf river basins, Florida, Alabama, and Georgia: Type IV Survey, 151 p.

U.S. Department of Commerce, 1972, Climate of the states, Florida: Nat1. Oceanic and Atmospheric Adm., Environmental Data Service, Climatography of the U.S. 60-8, 31 p.

1975, Climatological data, Florida, Annual Summary, 1975: Nat1. Oceanic and Atmospheric Adm., Environmental Data Service, Asheville, N. C.

U.S. Department of the Interior, 1974, Final environmental impact statement, phosphate leasing on the Osceola National Forest, Florida: Bur. Land Management, Eastern States office, 578 p.

U.S. Environmental Protection Agency, 1974, Reconnaissance study of radiochemical pollution from phosphate rock mining and milling:

National Field Inv. Center, Denver, Colorado, 90 p.

1975a, Preliminary findings, Radon daughter levels in structures constructed on reclaimed Florida phosphate land: Technical Note ORP/CSD-75-4, 32 p.

1975b, National interim primary drinking water regulations:

Federal Register, v. 40, no. 248, December 24, p. 59566-59588. 1976, Drinking water regulations, radionuclides: Federal

Register, v. 41, no. 133, July 9, p. 28402-28405.

1977, National interim primary drinking water regulations:

Federal Register, v. 42, no. 62, March 31, p. 17143-17146.

University of Florida, 1974, Florida statistical abstract, 1974: Univ. Florida Press, Coll. Business Adm. Bur. Econ. and Búsiness Research, $621 \mathrm{p}$.

Vernon, R. 0., 1951, Geology of Citrus and Levy Counties,Florida: Florida Geol. Survey Bul1. 33, 256 p.

Vernon, R. O., and Puri, H. S., 1965, Geologic map of Florida: Florida Board of Conserv., Div. Geology, Map Ser. 18. 
White, W. A., 1970, The geomorphology of the Florida peninsula: Florida Dept. Nat. Resources, Bur. Geology, Geol. Bull. 51, 164 p.

Winston, G. 0., 1976, Florida's Ocala uplift is not an uplift: Am. Assoc. Petroleum Geologists Bull., v. 60, no. 6, p. 992-994.

Wolff, R. G., 1970, Field and laboratory determination of the hydraulic diffusivity of a confining bed: Water Resources Res., v. 6, no. 1, p. 194-203.

Wolff, R. G., and Papadopulos, S. S., 1972, Determination of the hydraulic diffusivity of a heterogeneous confining bed: Water Resources Research, v. 8, no. 4, p. 1051-1058.

\U.S. GOVERNMENT PRINTING OFFICE: 1978 - 745 - 332/742 REGION NO. 4 



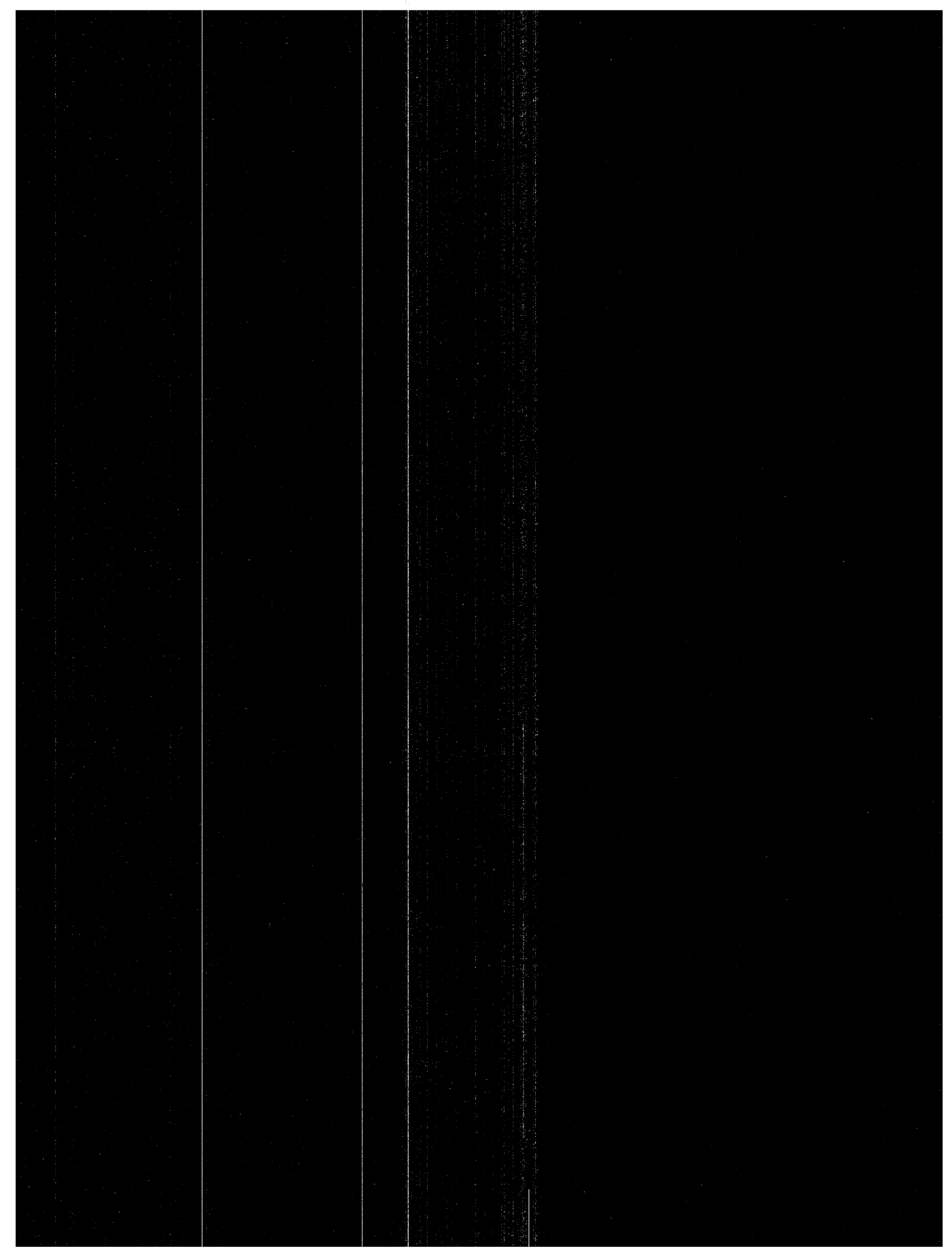




\section{का

2.

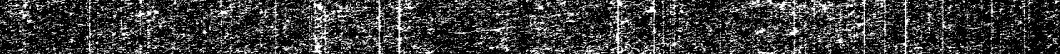

1.17. 1.1,

2.7.

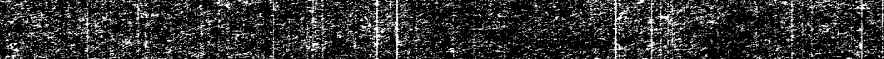

1.7.7.

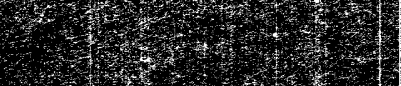

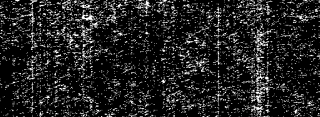

\section{$1,1 / 4 x^{3}$}

$4 x^{3}+x^{2}+3$

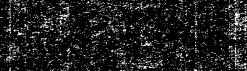

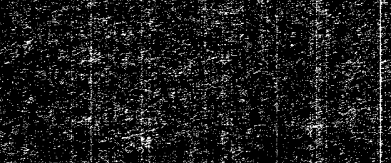

(5)

\section{4}
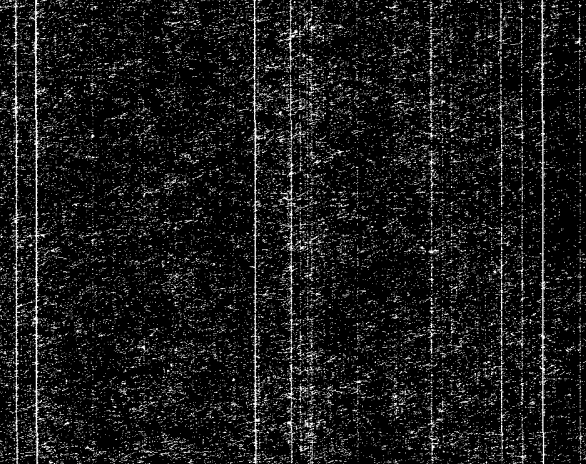

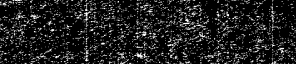

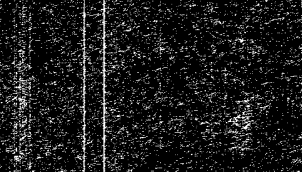

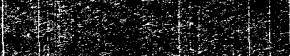
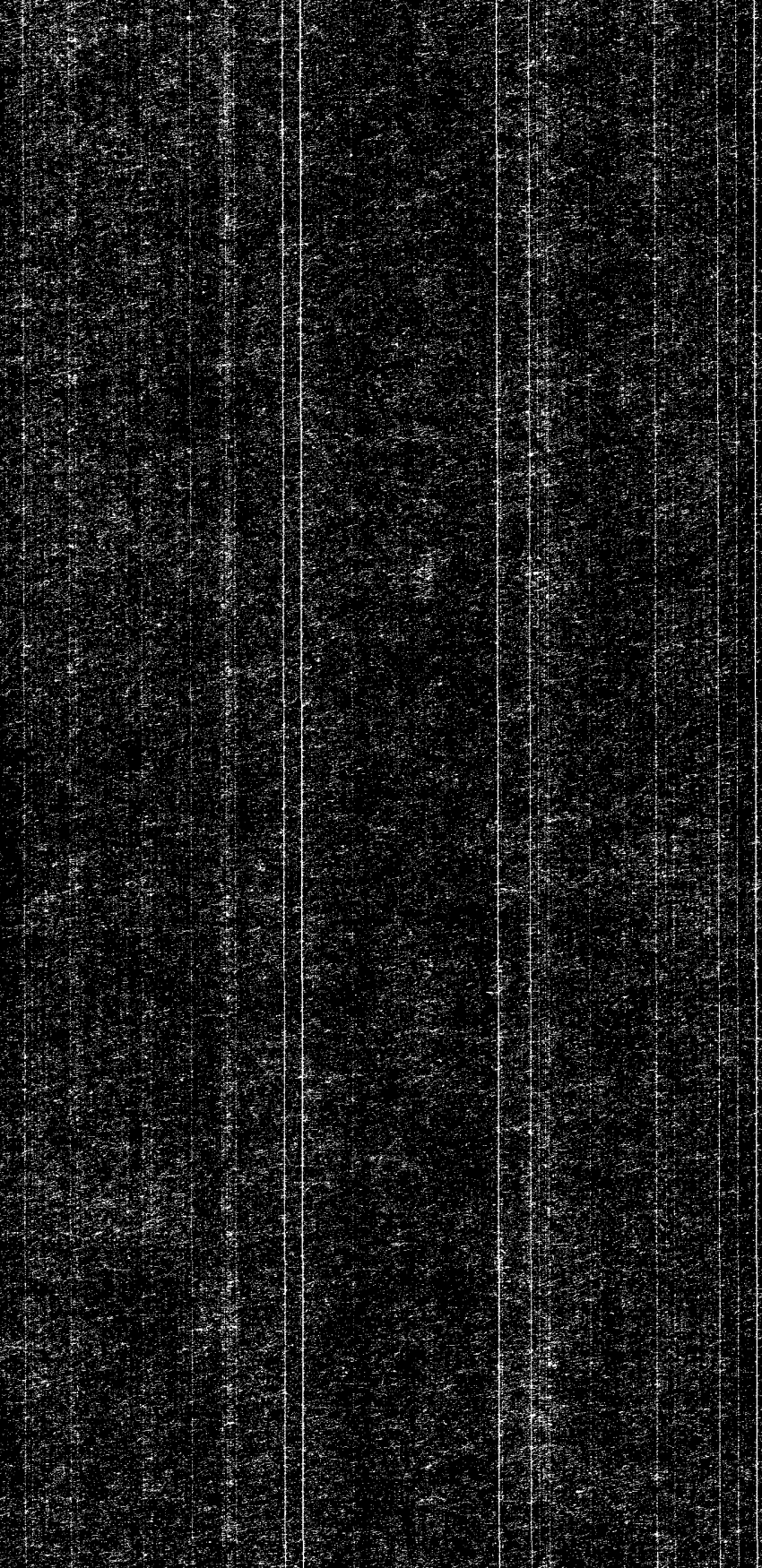

+x
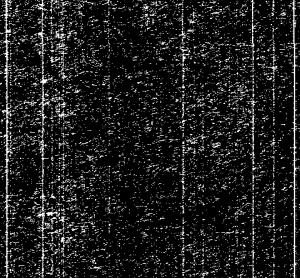